Portland State University

PDXScholar

\title{
Identifying Quality Function Deployment's Variables, Outcomes, Their Relationships, and Guidelines for Practitioners in the American Automotive Industry
}

Geoffrey Paul Gilmore

Portland State University

Follow this and additional works at: https://pdxscholar.library.pdx.edu/open_access_etds Let us know how access to this document benefits you.

\section{Recommended Citation}

Gilmore, Geoffrey Paul, "Identifying Quality Function Deployment's Variables, Outcomes, Their Relationships, and Guidelines for Practitioners in the American Automotive Industry" (1992). Dissertations and Theses. Paper 1157.

https://doi.org/10.15760/etd.1156

This Dissertation is brought to you for free and open access. It has been accepted for inclusion in Dissertations and Theses by an authorized administrator of PDXScholar. Please contact us if we can make this document more accessible: pdxscholar@pdx.edu. 


\section{IDENTIFYING QUALITY FUNCTION DEPLOYMENT'S VARIABLES, OUTCOMES, THEIR RELATIONSHIPS, AND GUIDELINES FOR PRACTITIONERS IN THE AMERICAN AUTOMOTIVE INDUSTRY}

by

GEOFFREY PAUL GILMORE

A dissertation submitted in partial fulfillment of the requirements for the degree of

DOCTOR OF PHILOSOPHY
in
SYSTEMS SCIENCE:
SINESS ADMINISTRATION

Portland State University (C) 1992 
TO THE OFFICE OF GRADUATE STUDIES:

The members of the Committee approve the dissertation of Geoffrey Paul Gilmore presented April 22, 1992.

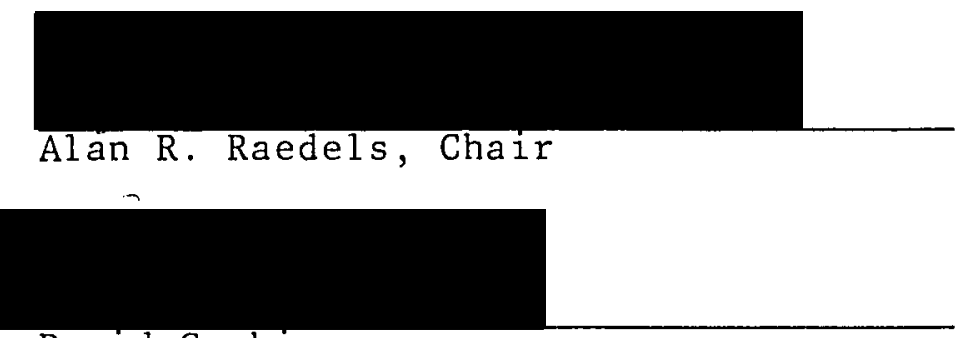

$$
\text { David Gerbing }
$$
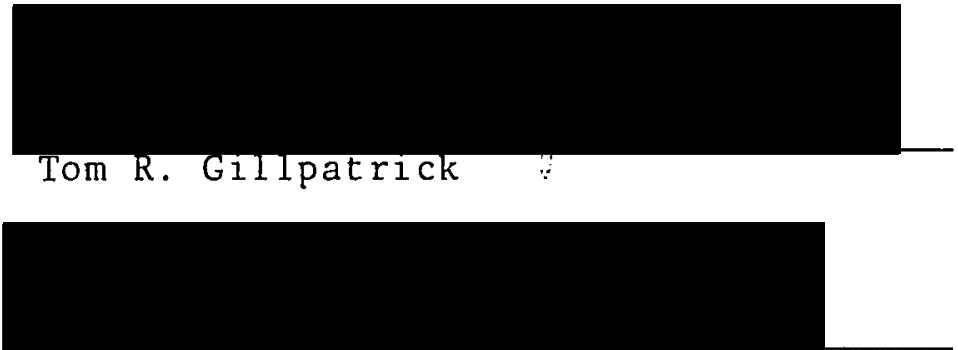

Harold A. Linstone

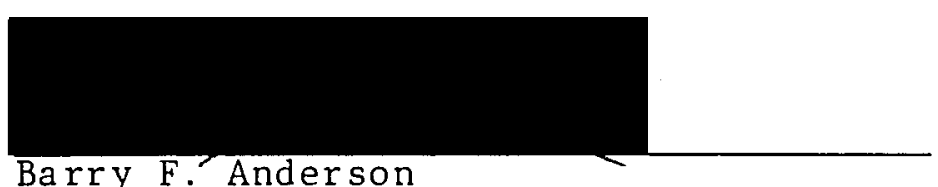

APPROVED :

Roy W. Koch, Director, Systems Science Ph.D. Program

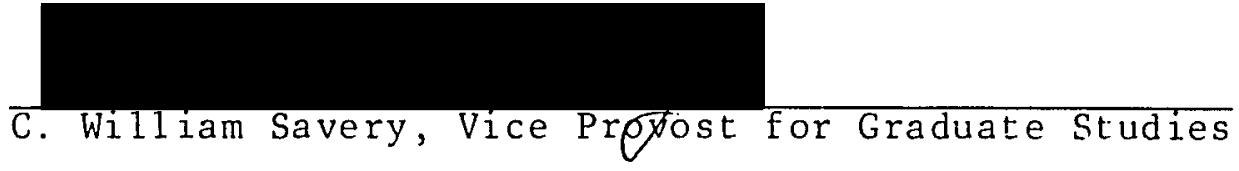


AN ABSTRACT OF THE DISSERTATION OF Geoffrey Paul Gilmore for the Doctor of Philosophy in Systems Science: Business Administration presented Apri1 22, 1992.

Title: Identifying Quality Function Deployment's Variables, Outcomes, Their Relationships, and Guidelines for Practitioners in the American Automotive Industry APPROVED BY THE MEMBERS OF THE DISSERTATION COMMITTEE:

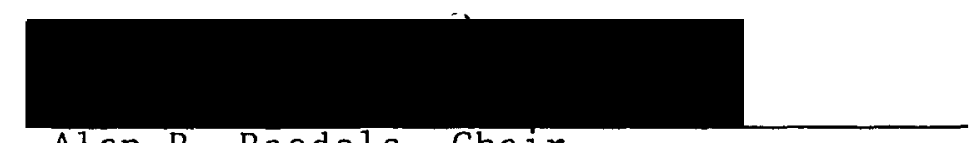

Alan R. Raedels, Chair

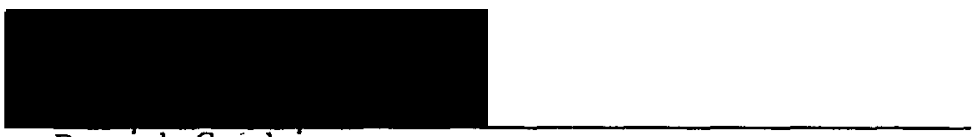

David Gerbing

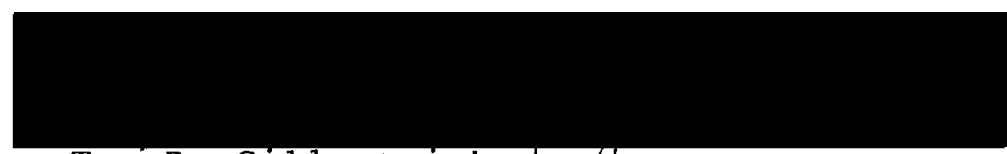

Tom R. Gillpatrick!')

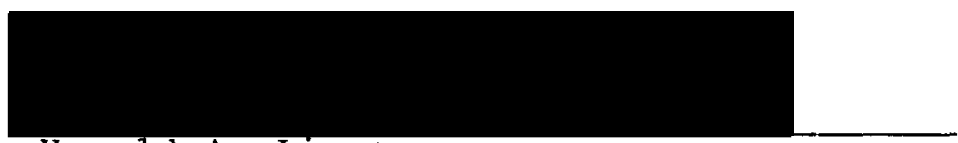

Harold A. Linstone

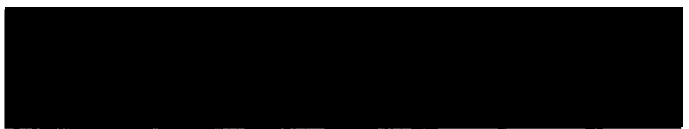

Barry F. Anderson

American industry is about nine to 12 years behind in utilizing a new product development and introduction process 
known as Quality Function Deployment (Q.F.D.). American industry must learn to compete internationally; the American automotive industry alone directly and indirectly employs millions of workers and has billions of: dollars in annual sales and profits at stake.

With the cooperation of one American automotive company research has been conducted on Q.F.D. The research objectives were to identify: what variables affect Q.F.D., what are the outcomes from Q.F.D., what relationships exist between Q.F.D. variables and outcomes, and what guidelines may be offered to Q.F.D. practitioners.

A Multiple Perspectives systems approach was used in developing both what and how Q.F.D. was to be researched. After a literature search a descriptive Q.F.D. model was developed. A Q.F.D. measurement instrument was developed and used to collect technical data. Interviews were used to collect organizational and personal data.

An $80 \%$ questionnaire response was obtained. Of the model's four outcomes Improved Design and Improved Communications had strong positive results with Improved Cost and Improved Time-to-Market unchanged. Explanations of these results were offered. A Factor Analysis was performed which verified that the three-level Q.F.D. model was appropriate and explained most of the response variation. A Reliability Assessment was conducted and the scales were found to be within or have exceeded the acceptable beginning 
research coefficient alpha range. A MANOVA Analysis was conducted, and five of the 17 Q.F.D. model's variables were identified as candidates for deletion for this company's present Q.F.D. system. A Ratio Data Assessment was conducted and used to develop five guidelines for this company's practitioners.

Organizational and Personal Data Assessments were conducted and their similarities with the Technical Data Assessment were noted. Top Management Commitment, Customer Information Availability, Team Composition and Dynamics and Project Completion Time were identified as important similar Q.F.D. variable findings. Improved Design and Improved Communications were identified as important similar Q.F.D. outcomes. No major discontinuities between the three assessments were found.

Research conclusions, contributions and future research work were identified. 


\section{ACKNOWLEDGEMENTS}

First and foremost I would like to extend my special appreciation and gratitude to my wife, Sue, and my son, Alex, for their patience and understanding during my doctoral course work and dissertation; their support was crucial to completing both.

Second I would like to extend my thanks to: Dr. Alan Raedels for his project coordination and guidance and his proofreading of my multiple dissertation drafts, Dr. Hal Linstone for his Multiple Perspectives Approach and guidance in its use, Dr. Dave Gerbing for his statistical assistance and Dr. Tom Gillpatrick for his research design methodology assistance.

Third I would like to extend my appreciation to Dr. W. Edwards Deming for his special mentoring and professional review of this dissertation work.

Finally I would like to recognize the American automotive company which allowed me access to their information; Oregon Cutting Systems for their questionnaire pretrial help; and Reynolds Metal, Tektronix and Warn Industries for their financial support. 
TABLE OF CONTENTS

PACE

ACKNOWLEDGEMENTS . . . . . . . . . . . . . . . . . . ii

LIST OF TABLES . . . . . . . . . . . . . . . . . . . viii

LIST OF FIGURES . . . . . . . . . . . . . . . . . . . $\mathrm{x}$

CHAPTER

I INTRODUCTION TO THE RESEARCH PROBLEM . . . . 1

Introduction . . . . . . . . . . . . . 1

Quality Function Deployment. . . . . 1

Research Objective and Questions . . . 11

Boundaries of the Dissertation . . . 12

Significance of the Dissertation . . . 13

Summary and Dissertation Organization. 16 ।

I I REVIEW OF THE LITERATURE AND THE

RESEARCH MODEL . . . . . . . . . . . . . . . 19

Introduction . . . . . . . . . . . . . 19

Model Framework . . . . . . . . . . 19

Model Elements . . . . . . . . . . . 21

Technical Variables (T1-T5). . . 24

Organizational Variables (06-013) . 27

Personal Variables (P14-P17) . . . 30

Outcomes (OUTl-OUT4) . . . . . . . 31

Contribution to the Literature . . . . 37

Summary . . . . . . . . . . . . . 37 
III DESIGN OF THE RESEARCH . . . . . . . . . . . 39

Introduction . . . . . . . . . . . 39

Research Hypotheses. . . . . . . . 40

Research Methodology . . . . . . . 43

Technical Assessment . . . . . . 43

Organizational Assessment . . . . 55

Personal Assessment . . . . . . . . 57

Integration of Assessments . . . . 58

Summary . . . . . . . . . . . . . . 59

IV FINDINGS OF THE RESEARCH . . . . . . . . . . 61

Introduction . . . . . . . . . . . 61

Mode1 Review . . . . . . . . . . 61

Technical Assessment Findings . . . . 62

Questionnaire Response . . . . . 62

Q.F.D. Variables Descriptive
Statistics and Histograms... . 62

Discussion on Design Findings. . . 64

Discussion on Cost Findings . . . . 66

Discussion on Time Findings . . . . 68

Discussion on Communication
Findings . . . . . . . . . . . . 69

Discussion on Integration

of Findings . . . . $:$. . . . . . 70

Q.F.D. Outcomes' Descriptive

Statistics and Histograms . . . 71

Design Findings. . . . . . . . . . 71

Cost Findings . . . . . . . . . . . 72

Time Findings . . . . . . . . . . . 72

Communication Findings . . . . . . . 73

Discussion on Integration

of Findings. . . . . . . . . . . . 73

Q.F.D. Variables Factor Analyses. . $\quad 74$

Reliability Assessment . . . . . . 80

MANOVA Analyses..... . . . . . 81

Discussion . . . . . . . . . . . . 83

Ratio Data Assessment. . . . . . 84

Discussion on Chart Size (T2) . . . 85

Discussion on Customer Information
Availability (T3). . . . . . . . 86

$\begin{array}{lll}\text { Discussion on Competitive } & \\ \text { Information Availability (T4) . } & 86\end{array}$ 


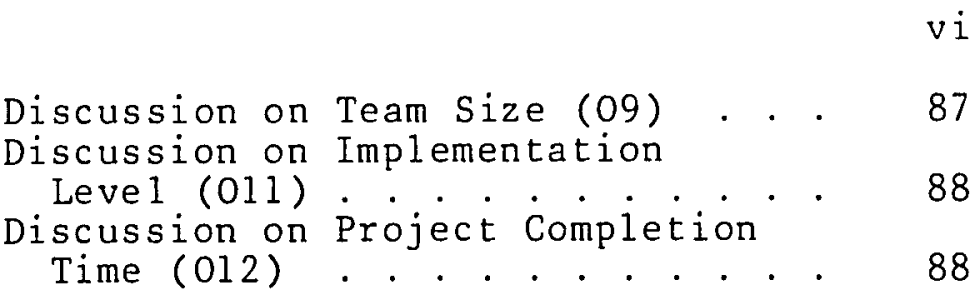

Organizational Assessment Findings . . 89

Idea 1 ก.F.D. Project Scenario. . . 90

Outstanding/Successful Q.F.D.

Project.............. . . 91

Typical Q.F.D. Project . . . . . . 95

Difficult/Unusual Q.F.D. Project . 97

Personal Assessment Findings . . . . 100

Outstanding/Successful Q.F.D. Project: Key Individuals'

Descriptions . . . . . . . . . . 100

Typical Q.F.D. Projert: Key Individuals' Descriptions. . . . 102

Difficult/Unusual Q.F.D. Project:

Key Individuals' Descriptions. . 103

Integration of Assessments . . . . . 105

Q.F.D. Variables' Assessments' Similarities . . . . . . . . . 105

Q.F.D. Outcomes' Assessments' Similarities . . . . . . . . . . 106

Q.F.D. Variables' Assessments' Discontinuities . . . . . . . . . . . 107

Q.F.D. Outcomes' Assessments'

Summary . . . . . . . . . . . . . . 107

$V$ CONCLUSIONS, CONTRIBUTIONS, FUTURE

RESEARCH RECOMMENDATIONS AND

SUMMARY OF THE RESEARCH

Introduction . . . . . . . . . . . . . 111

Conclusions of the Research... . . . 111

Contributions of the Research . . . . 113

Future Research Recommendations. . . 114 
Summary of the Research ....... . 116

Summary . . . . . . . . . . . . 122

REFERENCES ................... 123

APPENDICES

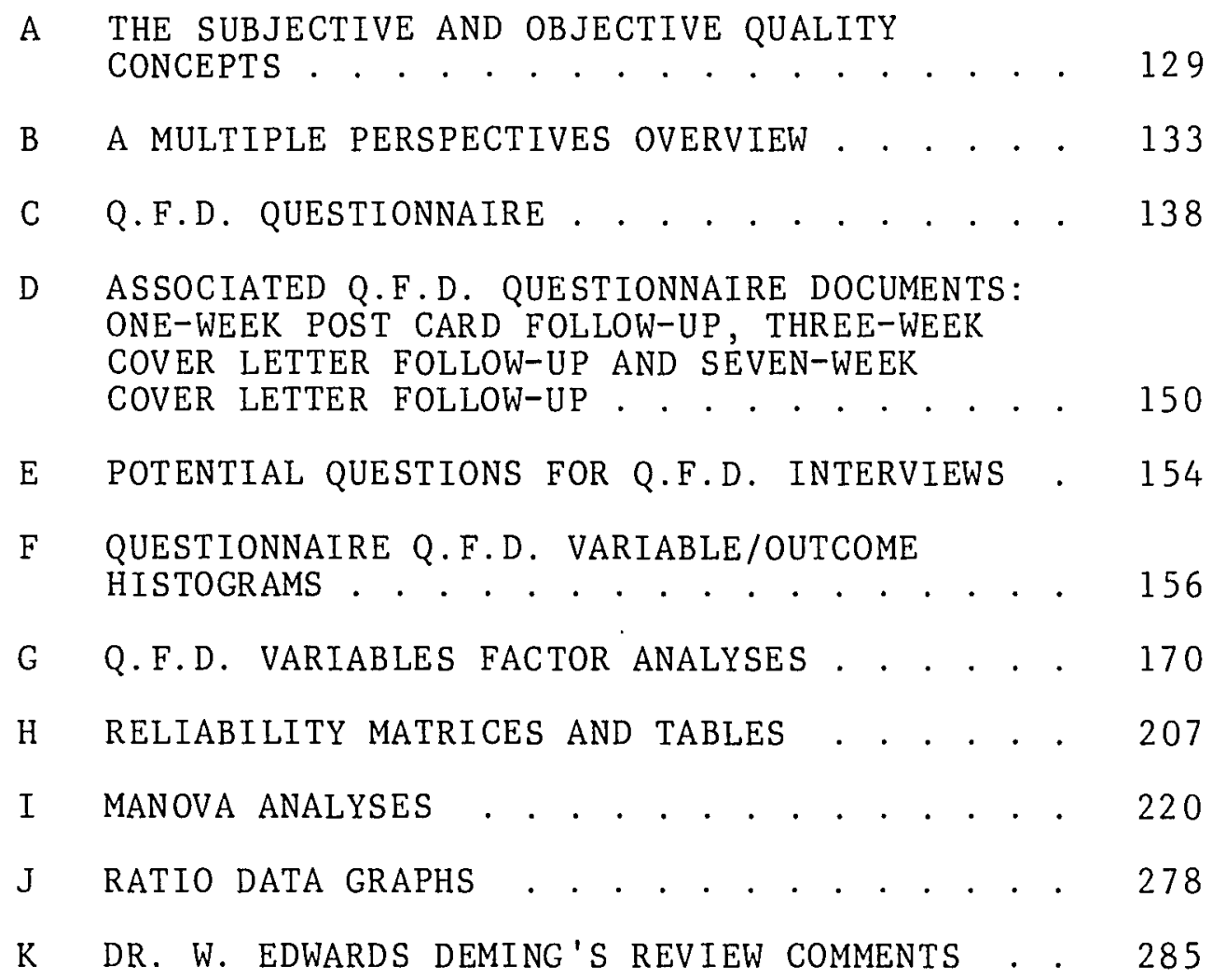




\section{LIST OF TABLES}

TABLE

PAGE

I Empty Illustration of Potential Q.F.D.

Variables' Descriptive Statistics . . . . 51

II Empty Illustration of Potential Q.F.D.

Outcomes' Descriptive Statistics . . . . 52

II Empty Illustration of Reliability

Assessment Summary . . . . . . . . . . . . 53

IV Empty Illustration of Q.F.D. Variables'

and Outcomes' MANOVA Summary . . . . . 54

V Potential Q.F.D. Variables'

Descriptive Statistics . . . . . . . 63

VI Potential Q.F.D. Outcomes'

Descriptive Statistics . . . . . . . 72

VII Factor Analyses Multi-Level Comparisons . . . 75

VIII Model and Factor Analysis Three-Level

Comparisons . . . . . . . . . . . . . 77

IX Reliability Assessment Summary . . . . . . . . 81

X Q.F.D. Variables' and Outcomes'

MANOVA Summary . . . . . . . . . . . . 
XI Summary of Ideal Q.F.D. Project's

$$
\text { Organizations, Goals, and }
$$

Postures and Procedures . . . . . . . . 92

XII Summary of Outstanding/Successful Q.F.D.

Project's Organizations, Goals, and

Postures and Procedures . . . . . . . . 94

XIII Summary of Typical Q.F.D. Project's

Organizations, Goals, and

Postures and Procedures . . . . . . . . 96

XIV Summary of Difficult/Unusual Q.F.D.

Project's Organizations, Goals, and Postures and Procedures . . . . . . . 99 


\section{LIST OF FIGURES}

\section{FIGURE}

PAGE

1. Three Types of Quality Features . . . . . . . 3

2. Typical Q.F.D. Chart . . . . . . . . . . 6

3. Primary Q.F.D. Chart Summary . . . . . . . 8

4. The Four Basic Q.F.D. Charts/Phases..... . 9

5. Annual Number of Japanese Q.F.D.

$$
\text { Case Presentations . . . . . . . . . }
$$

6. Evolution/Synthesis of Multiple

$$
\text { Perspectives . . . . . . . . . . . . } 22
$$

7. Q.F.D. Implementation Model's Framework. . . 23

8. Potential Q.F.D. Variables and

$$
\text { Their Sources . . . . . . . . . . } 25
$$

9. Potential Q.F.D. Outcomes and

Their Sources . . . . . . . . . . 26

10. Typical Design Change Process--

Aisen Warner... . . . . . . . . 32

11. Q.F.D. Startup Problem Reduction--

Toyota. . . . . . . . . . . . . . . 33

12. Q.F.D. Startup Costs Reduction--Toyota . . . 34

13. Questionnaire's Development Process . . . . 45 
14. Q.F.D. Practitioner's Guidelines

Graph Example . . . . . . . . . 54

15. Model and Factor Analysis Three-Level

Visual Summaries. . . . . . . . . 78

16. Idea1 Q.F.D. Project's Organizations and Relationships . . . . . . . . . 90

17. Outstanding/Successful Q.F.D. Project's Organizations and Relationships . . . . 93

18. Typical Q.F.D. Project's Organizations and Relationships . . . . . . . . 95

19. Difficult/Unusual Q.F.D. Project's Organizations and Relationships . . . . 97 
CHAPTER I

INTRODUCTION TO TEE. RESFARCH PROBLEM

\section{INTRODUCTION}

This dissertation provides information about Quality Function Deployment by identifying its variables, outcomes, their relationships, and some guidelines for practitioners. A brief description of Quality Function Deployment is presented in order to aid the reader in understanding the research problem. Next, the research objective, research questions and the boundaries of the dissertation are presented. With the research problem defined, the significance of the dissertation is discussed and the chapter is summarized. The dissertation's organization is then presented.

\section{QUALITY FUNCTION DEPLOYMENT}

Quality Function Deployment (Q.F.D.) is a product planning method for standardizing, connecting, and documenting each quality assurance step. Q.F.D. aids in understanding what the customer wants (subjective quality). These wants are then prioritized and translated into measurable design and process requirements (objective quality). If the reader 
is unfamiliar with the important distinction between subjective and objective quality concepts, a discussion is presented in Appendix A.

Q.F.D. may be used to plan the product, design the product, plan the manufacturing process, and plan the production controls utilizing prioritized customer needs and wants. Q.F.D. is cross-functional in nature and assists the communication of these customer needs and wants to the company's various departments and employees. Q.F.D.'s impact is to strengthen a producer's employees' knowledge of the customer's needs and wants and directly ties this knowledge to the employees' work. Therefore, customer satisfaction including subjective and objective quality is improved. The mechanics of the Q.F.D. process help demonstrate how this occurs.

Q.F.D. first starts out with obtaining the customer needs and wants. Q.F.D. generally considers three types of customer needs and wants (quality features) (see Figure 1) (28). First, there are the spoken (expressible) quality features that the customer can and will tell the producers about. An example would be: I want an automobile that seats six people. The second type of customer wants is the unspoken (expected) quality features that the customer can, but generally does not, tell the producers about. An example would be: I want a safe automobile. The customer expects these items, but seldom voices it. Sometimes 


\section{Customer Satisfaction}

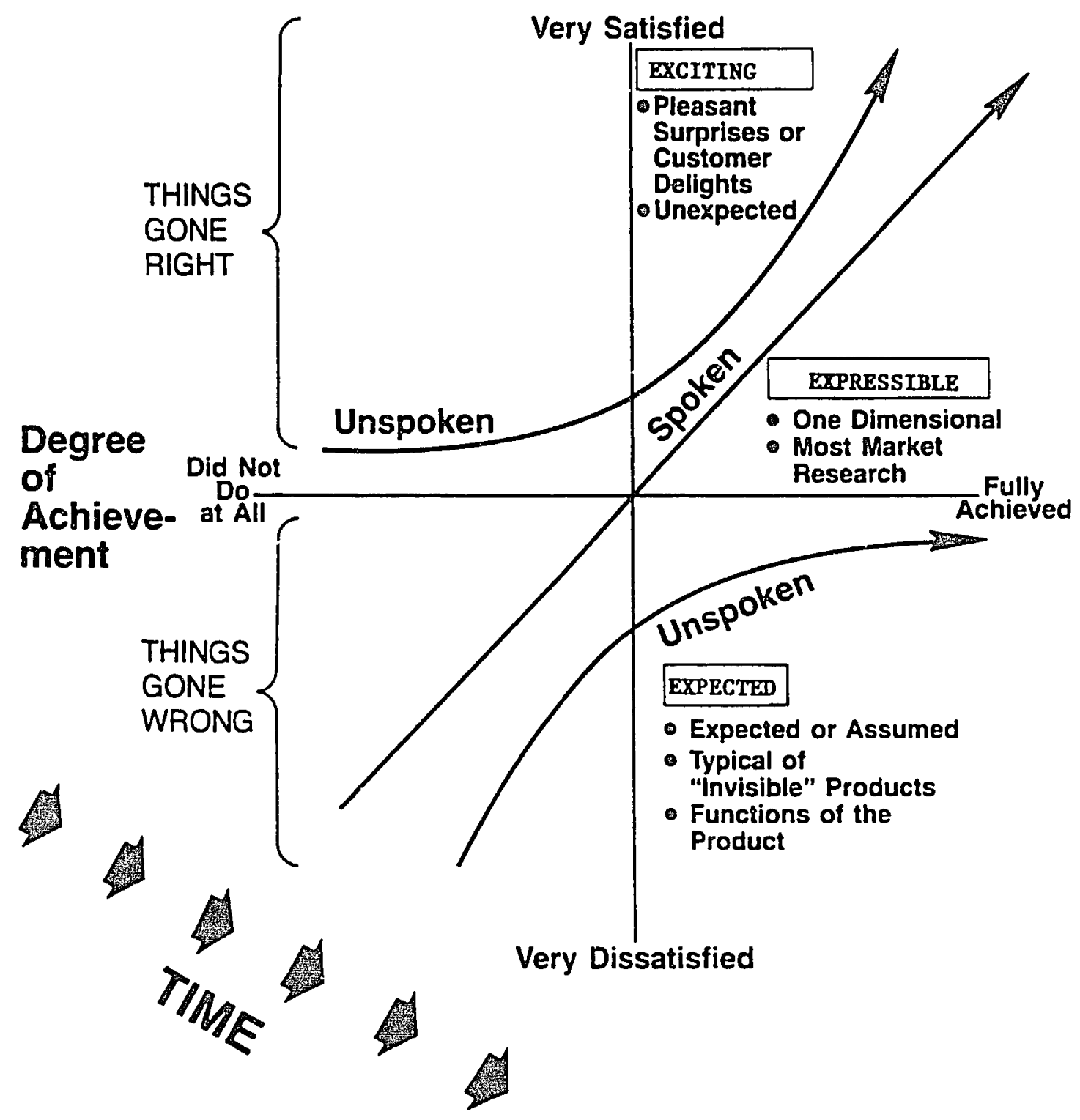

Adapted From the Kano Model

Figure 1. Three types of quality features. $(28,21)$ 
producers do not recognize and/or do not achieve these expected wants and marketing failures occur. The third type of customer wants consists of unspoken exciting quality features. These are new features or ideas that the customer cannot tell the producer about because they do not even know about them or their possibility; for example, new product features utilizing new technologies. The exciting quality features, over time, may tend to become expressible and even expected quality features and need to be reassessed periodically. An example of this quality feature migration is instant-on television.

In addition to trying to understand these three types of customer needs and wants, the Q.F.D. users (generally a cross-functional team) must also 1 isten to potentially more than one customer's voice. Besides the end user customer's voice another customer's voice may be the government's or society's voice--automobiles must be fuel efficient, less polluting, etc. Another customer's voice may be the distributors of the final customer product. Yet another customer's voice may be the assembler/integrator company utilizing the product. Thus, Q.F.D. considers multiple customer voices (usually by having separate Q.F.D. charts for each customer voice).

Since there are many opportunities to misunderstand the customers and their needs and wants (seats exactly six and no more? what does safe mean? how important to you is this 
new feature? which customer to listen to? etc.), this portion of the Q.F.D. process is systematic and iterative. Q.F.D. uses affinity grouping and tree diagramming techniques to try to ensure that gaps in the company's knowledge of the customer's needs or wants do not occur. Q.F.D. is iterative; it uses market research (surveys, focus groups, product return history, etc.) to ask the customers for product information. Q.F.D. then reformulates the questions and/or prototypes and repeats the process, asking the customers again, reformulating, asking the customers. . .

The second step of the Q.F.D. process is to translate these newly determined customer needs and wants into product design features and to do a competitive analysis. This is done by placing the customer needs and wants (written in customer language) horizontally down a chart. Vertically across the top of the chart are listed the design features or characteristics that the designers believe will impact those customer needs and wants. These design features are measurable and should affect the customers' perceptions of meeting their needs and wants. This portion of the Q.F.D. process is systematic, using affinity groupings and tree diagramming techniques too. See Figure 2 for an example of a typical Q.F.D. chart (67).

The interior of the Q.F.D. chart is then completed by indicating if and to what degree a relationship exists between the customer's needs/wants and the producer's design 


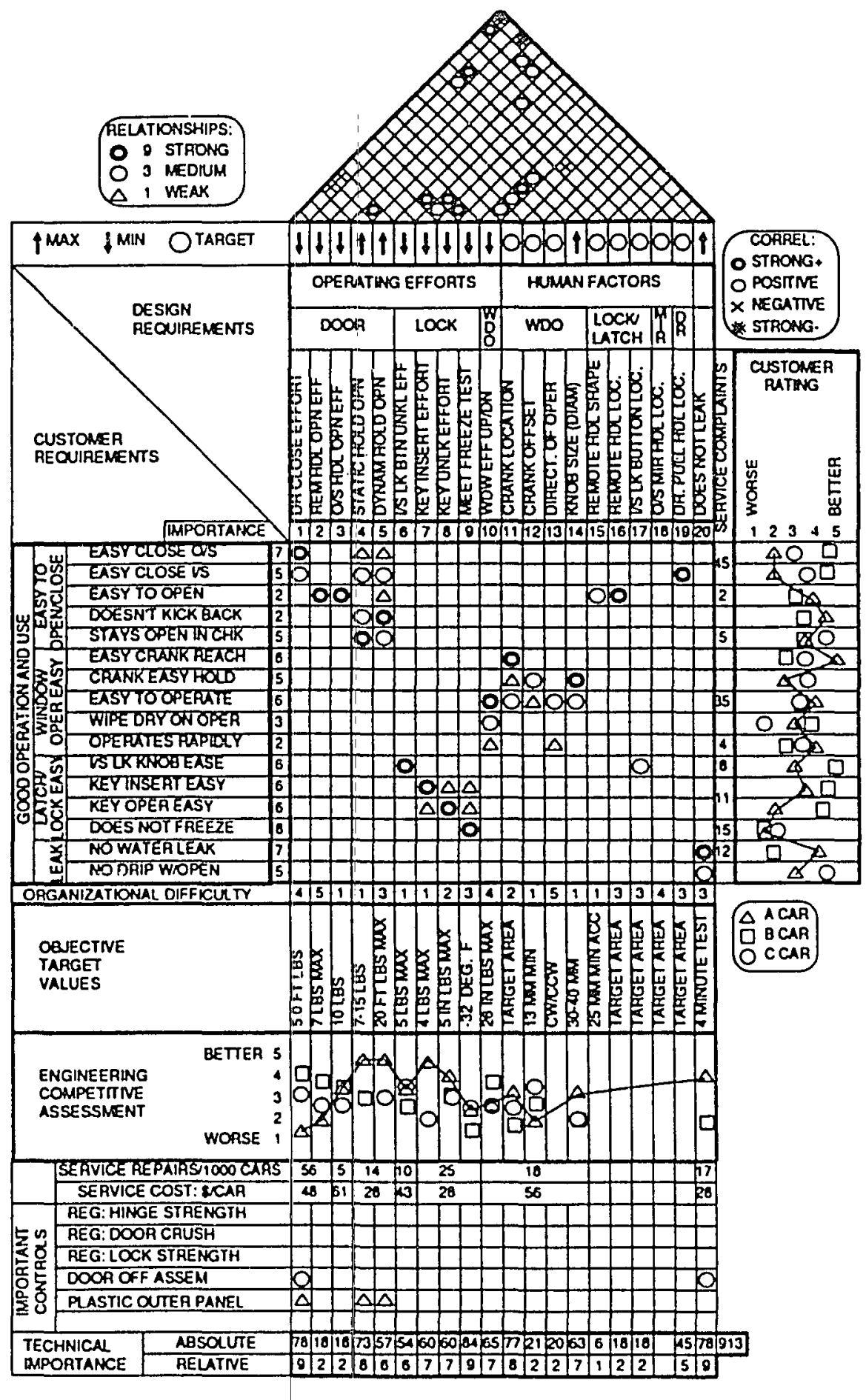

Figure 2. Typical Q.F.D. chart. $(67,38)$ 
features. Thus, from the Q.F.D. chart a clear detailed picture of the product's strengths and weaknesses emerges. Various other information may also be added to the Q.F.D. chart, such as, product improvement goals and design feature interrelationships. See Figure 3 for a summary of the primary Q.F.D. chart. This chart represents Level/Phase 1 of the Q.F.D. process (67).

The second phase in the Q.F.D. process is to construct another chart with the above determined product design characteristics listed down the horizontal rows and the parts (sub-components) characteristics listed across the vertical columns. Again, the interrelationships are shown in the body of the matrix. This completes Level/Phase 2 of the Q.F.D. process (see Figure 4). Thus, the customer requirements have now been translated into the design of the sub-components.

The third phase is to construct another chart with the above determined parts characteristics now listed down the horizontal rows and the manufacturing process characteristics listed across the vertical columns. Again, the interrelationships are shown in the body of the matrix. This completes Level/Phase 3 of the Q.F.D. process (see Figure 4). Thus, the customer requirements have now been translated into the design of the manufacturing process characteristics. 


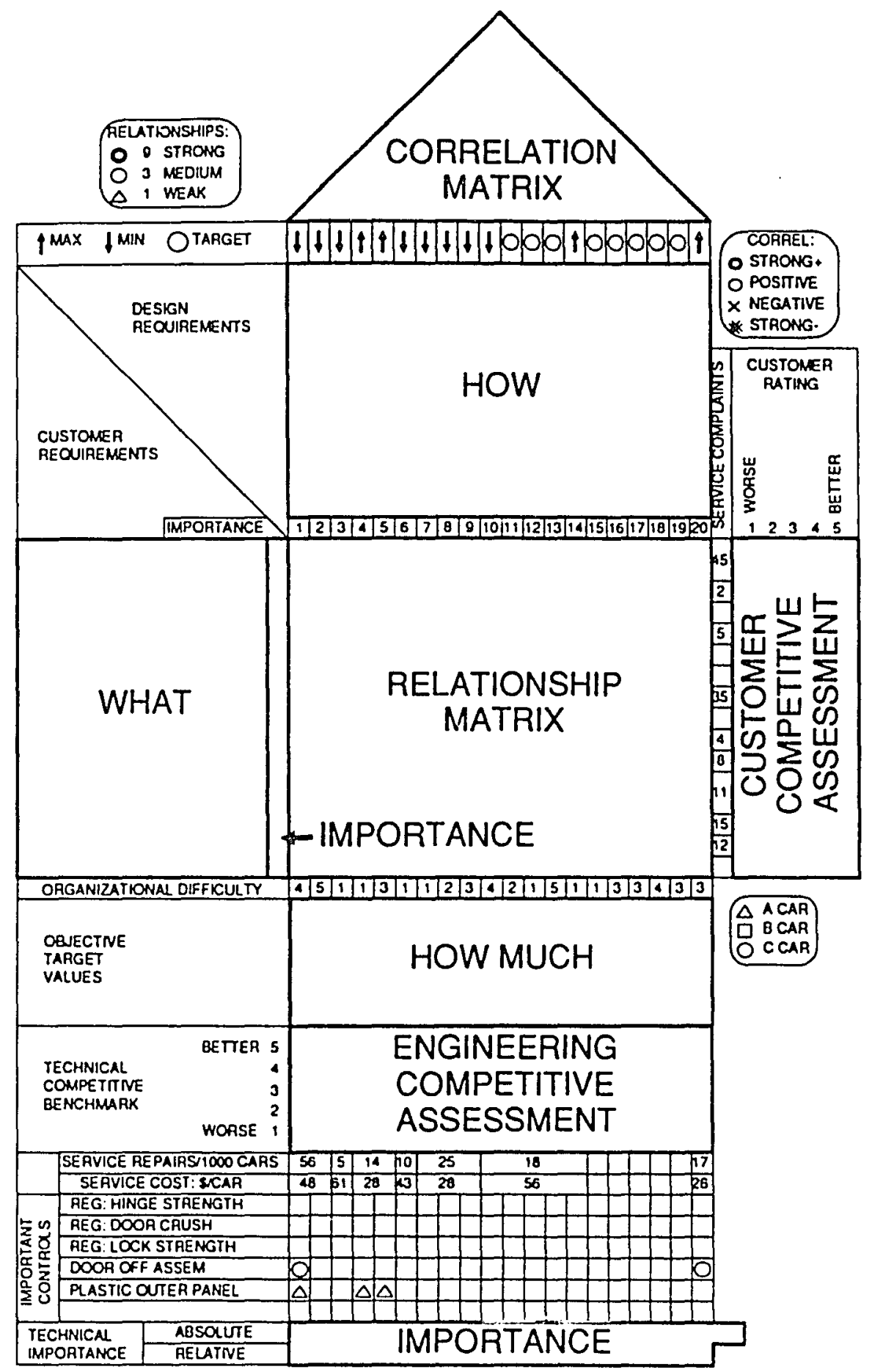

Figure 3. Primary Q.F.D. chart summary. $(67,53)$ 
The fourth phase of the Q.F.D. process is to construct another chart with the process characteristics now 1 isted down the horizontal rows and the production controls listed across the vertical columns. This completes Level/Phase 4, the last of the four basic Q.F.D. charts (see Figure 4). Thus, the customer requirements have now been translated into the relevant producer's production controls necessary to produce the product that will meet the customer's needs and wants.

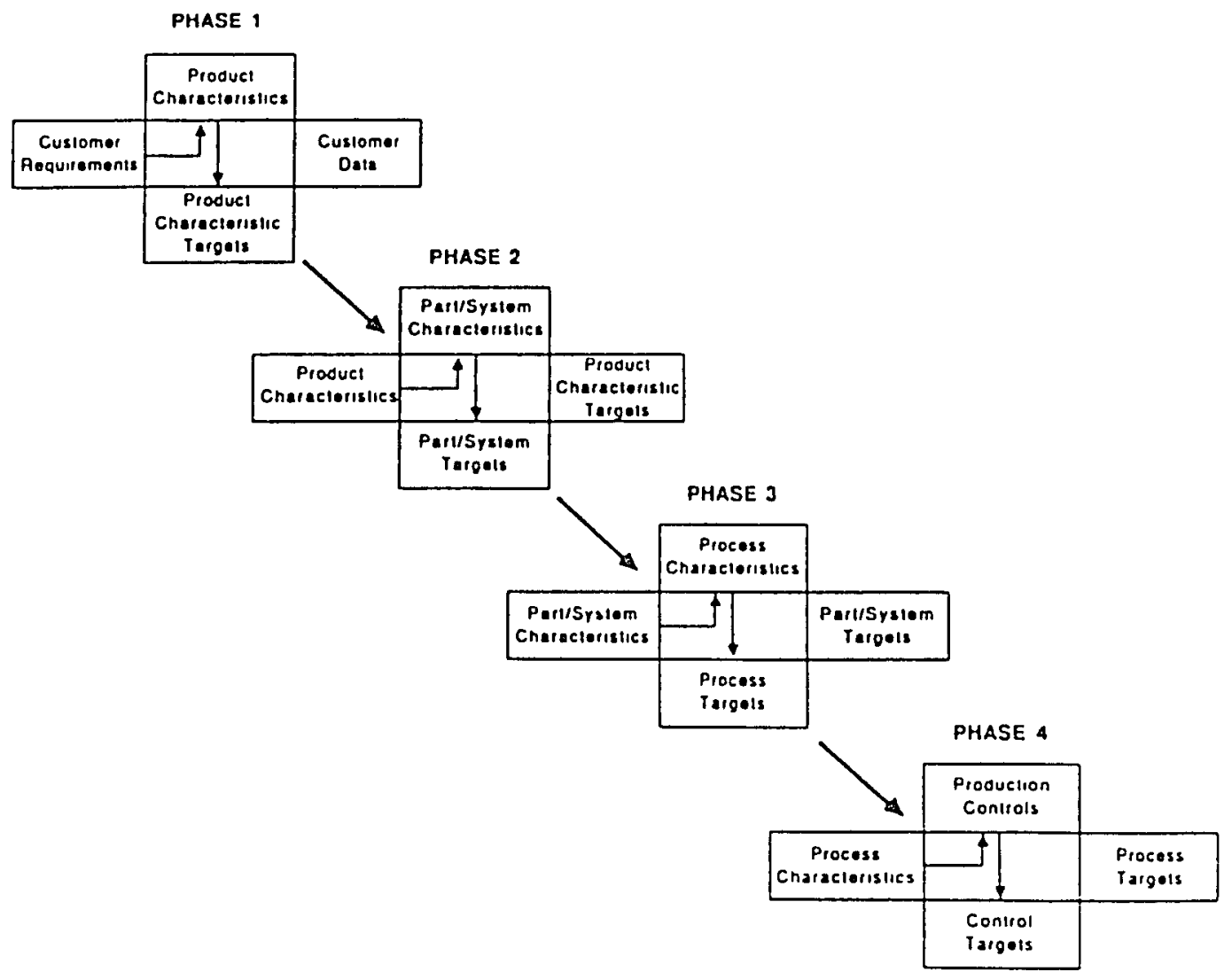

Figure 4. The four basic Q.F.D. charts/phases. 
Q.F.D.'s power is in the process and not necessarily in the chart numbers. The systematic and iterative use of market research data, and the systematic application of this knowledge, enforces a better understanding of the customer and taking the time to plan the product, its parts, the manufacturing process, and the production controls necessary to build that customer's required quality into the product. The process sweeps in the customer's perspectives and tries to maintain it through product delivery so that mistakes and oversights are avoided. Further, this design and planning information has been well documented in a concise manner for easy and clear communication to other employees interested in marketing, updating, or innovating the product. Since the customer's needs and wants change with time, the Q.F.D. chart(s) should be periodically reassessed (at the time of model updates, innovations, etc.).

Other charts beyond the four basic ones just described may be formed. These charts may systematically be used to examine (deploy) technology, cost, and reliability issues with customer needs, product design features, etc. In fact, at least 30 additional types of these charts have already been utilized in deploying quality, technology, cost, and reliability (37). These four different deployments (quality, technology, cost, and reliability) comprise a Total Quality Function Deployment System. This dissertation 
is researching only Quality Function Deployment and not these other Total Quality Function Deployment activities.

Q.F.D. has thus been described as systematically and iteratively searching out customers' demanded quality features. It also systematically plans and designs the product and production processes to meet these customers' needs and wants. Also, Q.F.D. systematically documents and communicates this information throughout the organization in a clear and thorough manner. With the Q.F.D. process described, the basic research objective and questions of this dissertation will now be discussed.

\section{RESEARCH OBJECTIVE AND QUESTIONS}

The research objective of this dissertation was to provide information about Q.F.D. To date, the information about and the research on Q.F.D. has been limited. Specifically the dissertation's task was to address the following four research questions:

1. What are the variables which affect Q.F.D.?

2. What are the outcomes from using Q.F.D.?

3. What relationships exist between Q.F.D. variables and outcomes?

4. What guidelines may be offered to practitioners of Q.F.D.?

The first two research questions were ones of identification. Potential variables which affect Q.F.D. were 
hypothesized and tested. Potential outcomes from using Q.F.D. were then hypothesized and tested.

The third and fourth research questions were ones of exploration. The previously identified Q.F.D. variables and outcomes may have relationships between each other. An examination of these variables and outcomes was conducted. Also some guideline graphs were constructed.

These research questions were generally applicable to Q.F.D. However, the dissertation applied these research questions to the subset of Q.F.D. described below.

\section{BOUNDARIES OF THE DISSERTATION}

This dissertation did not attempt to consider the Total Quality Function Deployment System (Quality, Technology, Cost and Reliability Deployment), but only dealt with the subset known as Quality Function Deployment.

This dissertation was further 1 imited to Q.F.D. as practiced in America and not in other countries. Different cultural contexts may affect the identification of Q.F.D. variables, outcomes, their relationships, and user guidelines (i.e., Japanese consensus vs. American individualistic decision making).

This dissertation did not attempt to consider external environmental variables which may affect the outcomes of Q.F.D. (i.e., oil crisis results in a product failure). 
Only internal variables (variables that users may directly control) are considered in this dissertation.

This dissertation was further confined to the American automotive industry. The American automotive industry is in the forefront of American industry in the number of Q.F.D. project applications. The American automotive companies have trained thousands of workers, have hundreds of projects completed or under way, and have the most experience with Q.F.D. While the electronics, medical, and light manufacturing industries are fast becoming very involved in the use of Q.F.D., different industries' different environments may affect the identification of variables, outcomes, their relationships, and user guidelines.

This dissertation was also confined to one of the major American automotive manufacturers. In order to have access to a major database of Q.F.D. information, competitive and confidential concerns necessitated this boundary restriction. Within these established boundaries the dissertation had access to approximately 100 Q.F.D. applications/projects and was a significant research effort for the reasons stated next.

\section{SIGNIFICANCE OF THE DISSERTATION}

After World War II the Japanese invited knowledgeable Americans to aid them in rebuilding their society. Specifically, they requested aid in rebuilding and improving their 
industrial facilities. They understood and applied the knowledge given to them. By the 1960 s Japanese product quality had risen dramatically. The Japanese had come to understand that meeting product specifications was not enough. Detecting quality problems by inspecting the finished product to specifications was too late. Reducing product variation by process controls and better planning and design could drastically improve the product's quality, reduce scrap and rework costs, and minimize detection costs. Moving upstream, from finished goods inspection, to inprocess inspection, to process controls, to better designs, led the Japanese to understand the importance of knowing the correct (customer focused) product design targets. By fully satisfying and surpassing their customers' needs and wants, satisfied and even excited customers would increase the Japanese product's market share (18). During this same time, American businesses used many various approaches for new product innovation and introduction (59).

In $1972 \mathrm{Dr}$. Yoji Akao (who first proposed Q.F.D. in 1966) was able to operationalize Q.F.D. at Mitsubishi Heavy Industries' Kobe Shipyard. From that start Q.F.D. is now the recommended Japanese technique for new product innovation and introduction and is being supported and/or taught by various academic, business, industry, and governmental organizations. The Japanese had quickly recognized the importance and value of knowing and using the customer's 
needs and wants (Q.F.D.). See Figure 5 for the number of Q.F.D. case presentations reported annually (4). The first book on Q.F.D. was published in Japan in 1978. Dr. Akao presented his Q.F.D. concept to Americans for the first time in Chicago, Illinois, during October 1983. With the first American application probably occurring in 1984 and the first American book publication in 1987 (37), America is about nine to 12 years behind the Japanese Q.F.D. experience curve.

With customer satisfaction determining market sales in the billions of dollars, which determines the location of millions of jobs and the ownership of billions of dollars of wealth, the significance of researching new product innovation and introduction processes such as Q.F.D. is asserted.

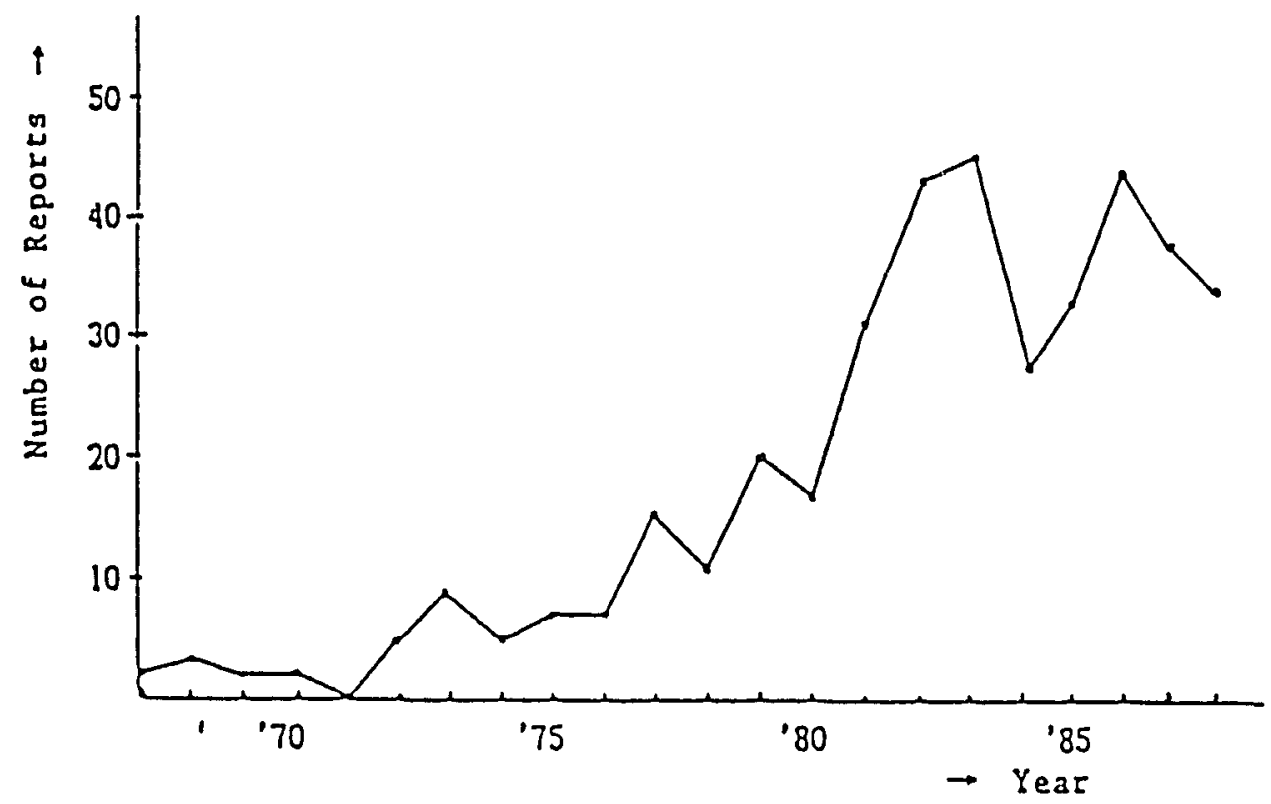

Figure 5. Annual number of Japanese Q.F.D. case presentations. $(4,9)$ 
To date, the eight-year-old American Q.F.D. experience has had some successes and failures. However, there has been very 1 ittle public research published on Q.F.D. As far as is known, the Japanese with their nine to 12 year experience lead have not publicly published any thorough research on Q.F.D. either.

Both present and future researchers and practitioners would benefit from additional knowledge concerning Q.F.D. The dissertation's information will enable researchers to further develop and test theories about Q.F.D. The information will also enable practitioners to adapt their implementation strategies and practices to improve the overall quality and productivity of Q.F.D.

Specifically, the information gained from this dissertation will aid the American automotive industry to overcome the nine to 12 year Q.F.D. experience curve disadvantage and compete more effectively in the international arena.

\section{SUMMARY AND DISSERTATION ORGANIZATION}

This dissertation's objective was to provide information about Q.F.D. After a brief description of Q.F.D., the research questions were stated. The four research questions were:

1. What are the variables which affect Q.F.D.?

2. What are the outcomes from using Q.F.D.? 
3. What relationships exist between Q.F.D. variables and outcomes?

4. What guidelines may be offered to practitioners of Q.F.D.?

This dissertation did not attempt to answer these research questions for all Q.F.D. applications. Boundaries on the dissertation were explicitly set as to include only the subset of the Total Quality Function Deployment System known as Quality Function Deployment. Also, only American Q.F.D.s were studied, with external environmental (non-user controllable) variables specifically excluded. The dissertation was further restricted to automotive applications. Finally, due to confidentiality and proprietary concerns, only one American automotive company's Q.F.D. experiences were researched. Even with these limitations there were about 100 Q.F.D. projects available to research. This dissertation provided significant information about Q.F.D. which will help the American automotive industry overcome a nine to 12 year Q.F.D. experience curve lag. This will lead to more successful competition in the international arena for billions of dollars of sales and wealth and the location of millions of jobs.

Having introduced the research problem, the next dissertation chapter reviews the literature and constructs a research model. Subsequent chapters discuss the design of the research, including the research hypotheses and 
methodology, as well as the dissertation's findings, summary, conclusions, and future research recommendations.

Finally, references and supporting appendices are presented. 
CHAPTER II

REVIEW OF THE LITERATURE AND

THE RESEARCH MODEL

\section{INTRODUCTION}

In order to meet the research objective of providing information about Q.F.D., a review was conducted to find out what information was already available. The research found that there were no descriptive or prescriptive Q.F.D. implementation models. This chapter develops a Q.F.D. implementation model framework and then synthesizes the model elements from the 1 iterature review and academic, expert, and practitioner inputs. The contribution to the Q.F.D. literature is then detailed and the chapter is summarized. The balance of the dissertation is then presented.

\section{MODEL FRAMEWORK}

A literature search was conducted with Q.F.D. and related wording as query topics. The literature search included business, engineering, and quality journal databases. In addition, published book databases were investigated. Prominent Q.F.D. educators, known authorities, and organizations (American Supplier Institute, GOAL/Q.P.C., 
etc.) were also asked to review and add to the bibliography entries. Of the 43 Q.F.D. entries, 32 were journal articles best described either as general overviews or general methodology explanations $(1 ; 4 ; 5 ; 7 ; 8 ; 12 ; 17 ; 19 ; 21 ; 23$; $24 ; 26 ; 27 ; 30 ; 31 ; 33 ; 34 ; 35 ; 38 ; 39 ; 45 ; 47 ; 49 ; 50 ; 54$; $56 ; 57 ; 62 ; 63 ; 64 ; 65 ; 68)$. Three entries were journal articles described as application examples $(11 ; 16 ; 70)$. Eight (six American, two Japanese translated) were softbound or hardbound books best described as methodology explanations and examples intermixed $(2 ; 3 ; 22 ; 28 ; 29 ; 37 ; 53$; 67 ) .

Next a new product innovation literature review was conducted. A summary and overview of the new product innovation literature was found (25). This article led to additional articles $(32 ; 43 ; 59 ; 60)$. All these articles dealt with the area of new product innovation marketing/ engineering interface (a portion of the Q.F.D. process). The articles referred to variables which might impact the outcomes from the new product innovation process.

The Q.F.D. literature search and the new product innovation literature review failed to find a descriptive or prescriptive implementation model of Q.F.D. Since models aid research by simplifying and organizing thoughts about the real object being modeled, they provide a basic starting point for researchers. Developing a Q.F.D. implementation model would be a helpful contribution to Q.F.D. research. 
Knowing that Q.F.D. by its very nature has both social and technical components led to a literature review of how socio-technical processes/situations may be analyzed (10; $41 ; 46 ; 66)$. An approach for examining socio-technical processes/situations known as Multiple Perspectives was selected as an appropriate methodology. A brief overview of Multiple Perspectives is presented in Appendix B for the unfamiliar reader. Figure 6 shows the evolution and synthesis of Multiple Perspectives. As may be seen from this figure, Multiple Perspectives analyzes. socio-technical processes/situations from three basic perspectives: technical, organizational, and personal. These three perspectives may be utilized in both how you analyze and what you analyze (41).

Utilizing the Multiple Perspectives approach to determine what to analyze, the framework for a Q.F.D. implementation model was constructed. Technical, organizational, and personal dimensions were hypothesized as affecting the outcomes from using Q.F.D. Figure 7 shows the Q.F.D. implementation model's framework. Next, specific elements of the Q.F.D. implementation model are discussed.

\section{MODEL ELEMENTS}

With the framework of the Q.F.D. implementation model constructed, the implementation articles and books were reviewed to find specific elements to complete the model. 


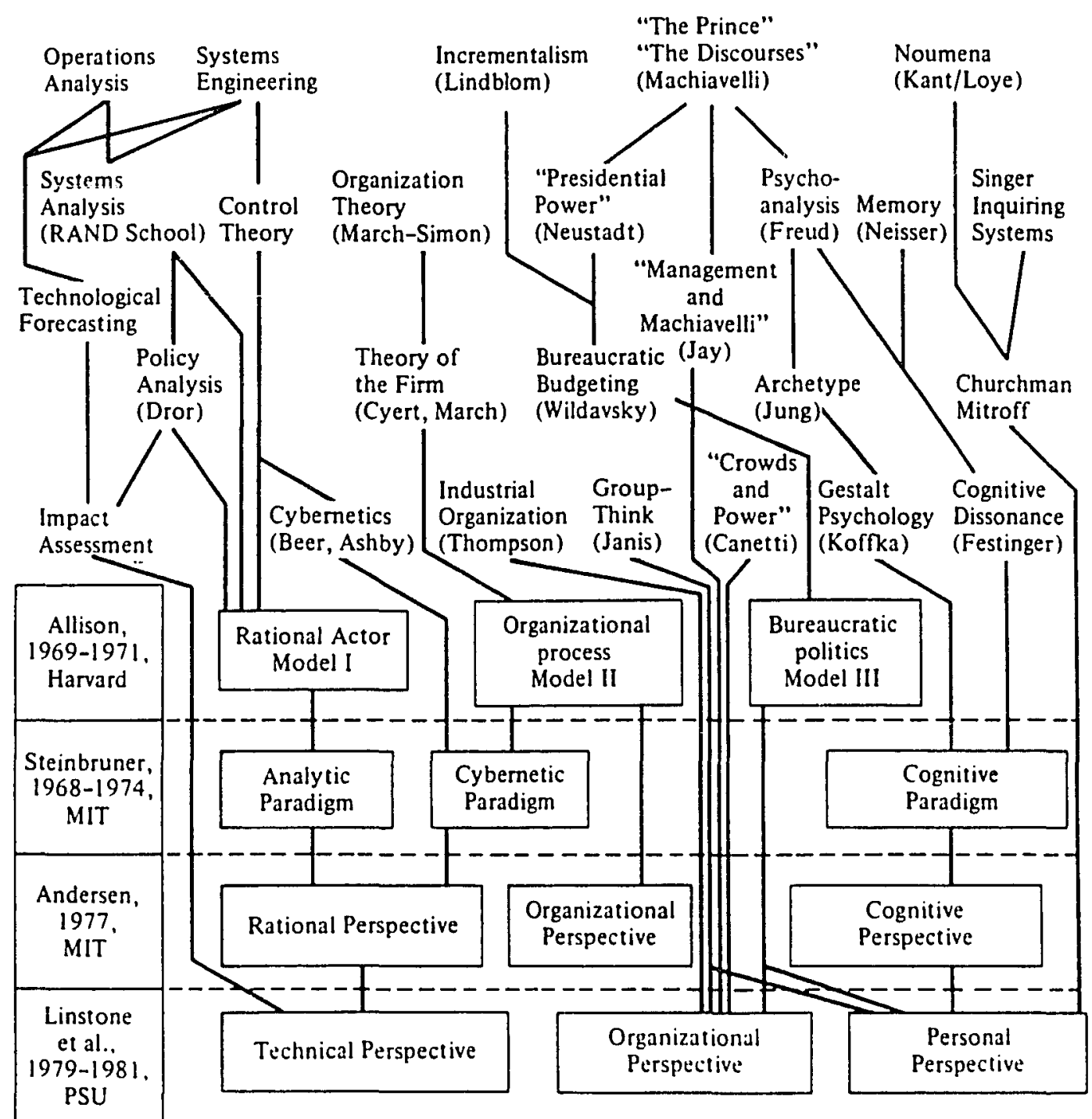

Figure 6: Evolution/synthes is of Multiple Perspectives. (41, 27) 


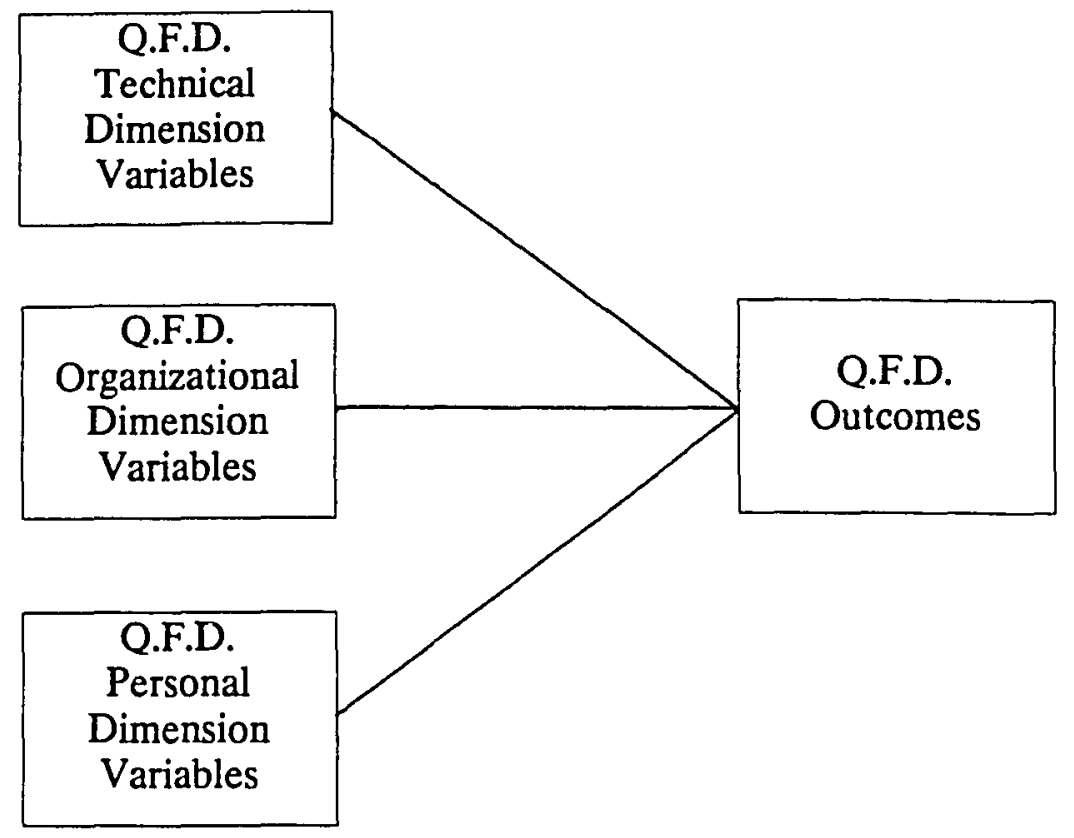

Figure 7. Q.F.D. implementation model's framework.

Comments on potential variables and outcomes were discovered. These model elements were categorized according to the model's framework. Next, over 20 academics, experts, and practitioners associated with design engineering, marketing, operations, quality, systems thinking, and especially Q.F.D. were consulted to add, delete, or rearrange the model elements inside the model's framework. The Q.F.D. implementation model's specific potential Q.F.D. variables and the associated sources were summarized in Figure 8 . The Q.F.D. implementation model's specific potential Q.F.D. outcomes and the associated sources were summarized in 
Figure 9. Each of the Q.F.D. implementation model's 17 variables and four outcomes is discussed in turn.

Technical Variables (TI-T5)

The variables which dealt with the Q.F.D. methodology (i.e., collecting information, determining numerical values, building charts, etc.) were grouped as the relevant technical variables. A discussion of the five potential technical variables follows.

Chart Building Methodology (TI). Both Akao (3) and King (37), noted Q.F.D. proponents, warn that incorrect methodology will yield incorrect product. The methodological procedural trap of the task becoming completing the chart and completing "cookbook" procedures rather than the task being understanding and satisfying the customer's needs and wants was mentioned too $(1 ; 7 ; 19 ; 28 ; 29 ; 31 ; 50 ; 53$; $68 ; E ; P)$.

Chart Size/Complexity (T2). The literature discusses the chart size/complexity issue. If not prioritized, the end items grow rapidly. A 30 customer wants by 30 design features chart has 900 possible interrelationships. Akao (2;3) and the Q.F.D. training materials 1iterature (28; 29; 37 ; 50) especially stressed this point. Other references included $1 ; 7 ; 22 ; 27 ; 34 ; 39 ; 49 ; 53 ; 59 ; \mathrm{E} ; \mathrm{P}$.

Customer Information Availability (T3). Initial knowledge of customer needs and wants is the starting point for 
Model Framework Model Elements

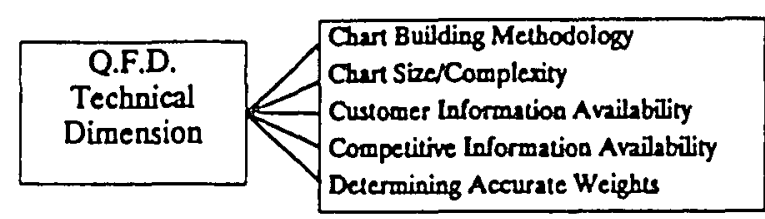

Sources

$4,3,7,19,28,29,31,37,50,53,68, E, P$ $2,3,7,11,22,28,29,31,37,50,53,64,68$, E, P $1,2,3,5,7,22,27,28,29,34,37,39,49,50,53,59$, E, P $3,22,28,37,47,50,53, E, P$ $2,3,7,28,29,37,50,53,59$, E, P

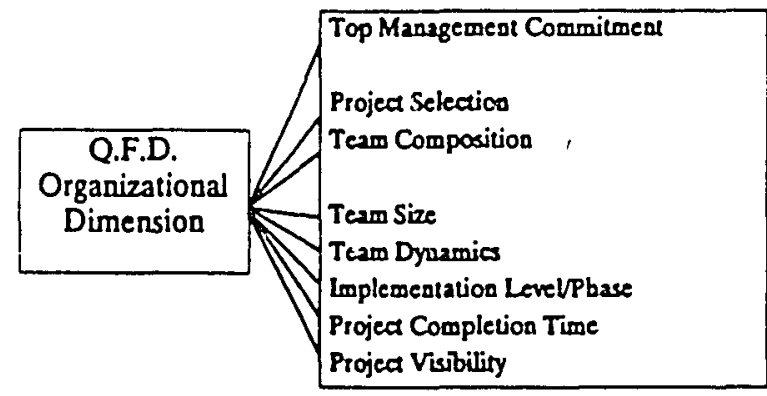

\begin{tabular}{|c|l} 
Q.F.D. \\
Personal \\
Dimension
\end{tabular}$\quad \begin{aligned} & \text { Personal Commilment } \\
& \text { Training and Experieoce } \\
& \text { Personal Power } \\
& \text { lndividuals' Avallable Work Tume }\end{aligned}$

$1,2,3,22,25,28,29,32,33,37,39,45,50,53,62,65,68$ $A, E, P$

$2,3,7,8,22,28,29,37,47,50,53,68$, E, P $23,7,11,21,22,23,26,27,22,29,32,37,43,45,47,49$, $50,53,60, A, E, P$ $2,7,37,53,60$, A, E, P

$1,23,7,22,28,29,32,37,43,45,50,53,60,68, A, P$ $1,3,19,37,50,60, E, P$

$1,23,11,22,23,28,29,31,37,45,50,53,59,64,68, E, P$ $25,28,32,53,60, A, P$

\section{1, 27, 53, A, E, $P$}

$1,23,4,7,8,22,28,29,37,50,53, A, E, P$

$2,7,8,32, A, E, P$

$2,22,23,28,50,53, A, E, P$

\begin{tabular}{|l|}
\hline \multicolumn{1}{|c|}{ LEGEND } \\
\hline No. - Bibliograpby Sourees \\
$\mathbf{A}$ - Academic Sources \\
$\mathbf{E}$ - Expern Sources \\
$\mathbf{P}=$ Practitioner Sources \\
\hline
\end{tabular}

Figure 8. Potential Q.F.D. variables and their sources. 


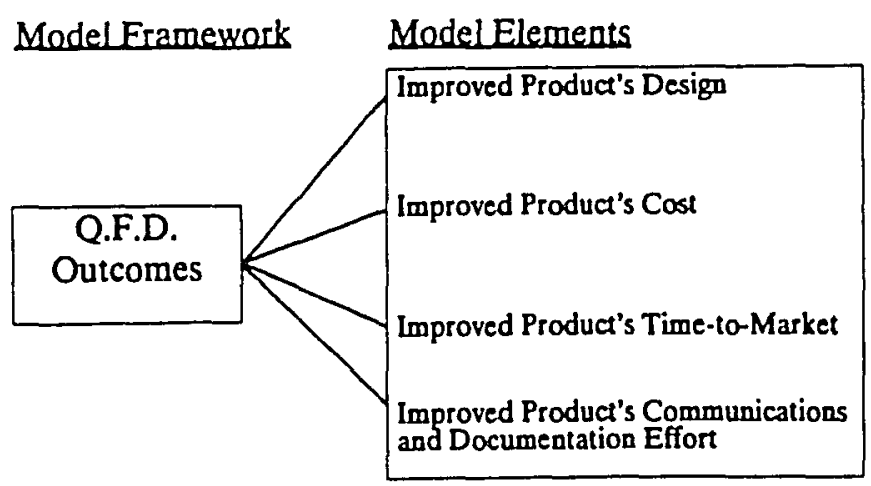

Sources

$1,2,3,4,5,7,8,11,16,19,21,22,23,24$, $27,28,29,35,37,38,39,45,47,49,50$, $53,56,59,64,67,68,70, A, E, P$

$1,2,3,4,7,8,16,22,23,24,27,28,29$, $35,37,38,39,45,47,49,53,59,64,67$, $68, A, E, P$

$1,2,3,4,16,22,23,24,28,29,35,37,38$ $45,49,53,64,67,68,70, A, E, P$

$1,2,8,11,12,16,19,21,22,23,24,28$ $29,37,45,47,50,53,56,62,64,67$, E, P

\begin{tabular}{|l|}
\hline \multicolumn{1}{|c|}{ LEGEND } \\
\hline No. = Bibliography Sources \\
$A=$ Academic Sources \\
$E=$ Expert Sources \\
$P=$ Practitioner Sources \\
\hline
\end{tabular}

Figure 9. Potential Q.F.D. outcomes and their sources.

product development (59). While this knowledge may be difficult and time consuming to collect, generally the literature recognized its importance and that Q.F.D. encourages seeking more customer information. Again, Akao (2; 3; 5), King (37), and the training materials $(28 ; 29)$ highlighted this variable. Nicholson (50) in particular offers methods for aiding the collection of customer information. Other references included $1 ; 7 ; 22 ; 27 ; 34 ; 39 ; 49 ; 53 ; 59$; E; P.

Competitive Information Availability (T4). For a significantly new concept/product, determining the competition may be very difficult. When Q.F.D. is used to update 
and improve an already existing marketed product, this is less likely to be a problem. Only a few sources $(3 ; 22 ; 28$; $37 ; 47 ; 50 ; 53 ; E ; P)$ mentioned this concern.

Determining Accurate Weights (T5). Akao (2;3) and Aswad (7), as well as the training materials (28; 29; 37), discuss the trial and error subjective process that Q.F.D. utilizes to determine weights of customer importance, perceptions, and chart interrelationships. Aswad (7), in particular, called for research to improve this process. Use of inaccurate customer information, especially statistically invalid customer information, may result in inappropriate product designs $(50 ; 53 ; 59 ; \mathrm{E} ; \mathrm{P})$.

Organizational Variables (06-013)

The variables which dealt with organizations' decisions, formation, strength, and stability were grouped as the relevant organizational variables. A discussion of the eight potential organizational variables follows.

Top Management Commitment (06). Many sources cited this variable as being crucial. Academics, experts, and practitioners; the new product introduction literature sources $(25 ; 32)$; the training materials $(2 ; 3 ; 28 ; 29 ; 37$; $50)$; and others $(1 ; 22 ; 33 ; 39 ; 45 ; 53 ; 62 ; 65 ; 68)$ all stated that top management commitment was imperative for new product introduction/Q.F.D. success. 
Project Selection (07). The training materials literature $(3 ; 28 ; 29 ; 37 ; 50)$ especially discussed how appropriate Q.F.D. project selection may encourage a company's Q.F.D. success. They recommended that initial Q.F.D. pilot projects be ones that update existing products rather than projects that are brand new concepts or brand new market product introductions. This was to allow for learning the Q.F.D. process without the added problem of learning a brand new product market, new customer profile, new manufacturing technology, and/or new product technology. Others $(2 ; 7 ; 8$; $22 ; 47 ; 53 ; 68$ ) simply stated that project selection was a variable or that a problem product should be selected so as to show a large degree of improvement/success with Q.F.D. This success may then be used as a showcase to encourage further Q.F.D. implementation. Experts and practitioners concurred that project selection may affect Q.F.D. outcomes. Team Composition (08). This variable was the most often cited as necessary to the new product introduction/Q.F.D. process. In a11, 201 iterature sources and academics, experts, and practitioners cited team composition as an important variable in product introduction/Q.F.D. Q.F.D. is cross-functional in nature and should have team members representing marketing, design engineering, and manufacturing areas $(2 ; 3 ; 7 ; 11 ; 21 ; 22 ; 23 ; 26 ; 27 ; 28$; $29 ; 32 ; 37 ; 43 ; 45 ; 47 ; 49 ; 50 ; 53 ; 60)$. 
Team Size (09). A scattering of sources $(2 ; 7 ; 37 ; 53$; 60) briefly mentioned that when teams get large they may take longer to complete a project. Academics, experts, and practitioners concurred.

Team Dynamics (010). Akao (2;3), King (37), and the training materials $(28 ; 29 ; 50)$ discussed the affect esprit de corps or lack of good team member interactions (marketing member vs. engineering member) may have on the process. Other references included $1 ; 7 ; 22 ; 32 ; 43 ; 45 ; 53 ; 60 ; 68$; A; P.

Implementation Level/Phase (011). Akao (3), King (37), and Nicholson (50) mentioned the importance of completing the Q.F.D. process through the production controls stage (Level/Phase 4). Others $(1 ; 19 ; 60)$ see most value in the up front determination, understanding, and documentation of the customer's needs and wants and the competitive assessment (all Level/Phase 1 activities). The views were not contradictory, but rather complementary, and experts' and practitioners' statements confirmed that all Levels/Phases should contribute toward success. The more experienced Q.F.D. sources $(3 ; 37 ; 50)$ stated the importance of completing each next Level/Phase. Less experienced Q.F.D. sources stated that understanding the customer and the competition $(1 ; 19 ; 60)$ provided the major benefit.

Project Completion Time (012). A large body of references cited imposed project completion times (the desire for 
immediate results, rushing product to market) as a variable that detrimentally affected Q.F.D. or any new product introduction process $(1 ; 2 ; 3 ; 11 ; 22 ; 23 ; 28 ; 29 ; 31 ; 37 ; 45$; $50 ; 53 ; 59 ; 64 ; 68 ; E ; P)$.

Project Visibility (013). The new product introduction literature review $(25 ; 32 ; 60)$ discussed that the more visible or important a new product project was, the better chance for success the new product had. Other references included $28 ; 53 ; \mathrm{A} ; \mathrm{P}$.

Personal Variables (P14-P17)

The variables which dealt with an individual's aspect of and ability to affect Q.F.D. were grouped as the relevant personal variables. A discussion of the four potential personal variables follows.

Personal Commitment (P14). Mostly academics, experts, and practitioners discussed that the greater an individual's (the Q.F.D. team leader or a team member) personal belief in Q.F.D., recognized need for Q.F.D., and commitment to Q.F.D., the more energy that individual will expend on doing Q.F.D. and, hence, improve the Q.F.D. project outcome. One practitioner source (53), one book (22), and one article (1) also referred to this variable.

Training and Experience (P15). Akao (2;3;4), King (37), the training materials $(28 ; 29 ; 50)$, academics, experts, and practitioners referred to an individual's prior 
Q.F.D. training and experience as favorably impacting the Q.F.D. process. Other references included $1 ; 7 ; 8 ; 22 ; 53$. Personal Power (P16). Academics and practitioners referred to individuals (the Q.F.D. team leader or a team member) using leadership position and/or influence--that is, their personal power--to impact the Q.F.D. process. Other references included $2 ; 7 ; 8 ; 32$. Experts, when queried on the subject, concurred.

Individuals' Available Work Time (P17). Practitioners referred to individuals on the Q.F.D. team as not being given enough time to work thoroughly on the Q.F.D. project. Academics and experts, when queried, concurred that this may be a variable that impacts Q.F.D. One practitioner source (53), one book (22), Akao (2), Fosse (23), Nicholson (50), and one training material source (28) briefly referenced this topic as well.

Outcomes (OUT1-OUT4)

The specific potential Q.F.D. variables are important to study only if Q.F.D. provides outcomes significantly better than a company's prior methodology. The Japanese have reported measuring some of these Q.F.D. outcomes (see Figures 10, 11, and 12). After conducting the Q.F.D. literature search and the new product introduction literature review, four specific model elements were proposed to categorize Q.F.D.'s potential outcomes. These four specific 
potential Q.F.D. outcomes were reviewed by academics, experts, and practitioners in the same manner as the 17 specific potential Q.F.D. variables which were discussed earlier. The four specific potential Q.F.D. outcomes are improved product's design, improved product's cost, improved product's time-to-market, and improved product's communications and documentation effort. See Figure 9 for a summary of these potential Q.F.D. outcomes and their associated sources. Each of the Q.F.D. implementation model's four outcomes is discussed in turn.

Improved Product's Design (OUT1). The majority of the 1 iterature sources referenced Q.F.D.'s improved product design. This is Q.F.D.'s main claim to being an improvement over the prior practices. The systematic and iterative

\section{CHANGE COMPARISON}

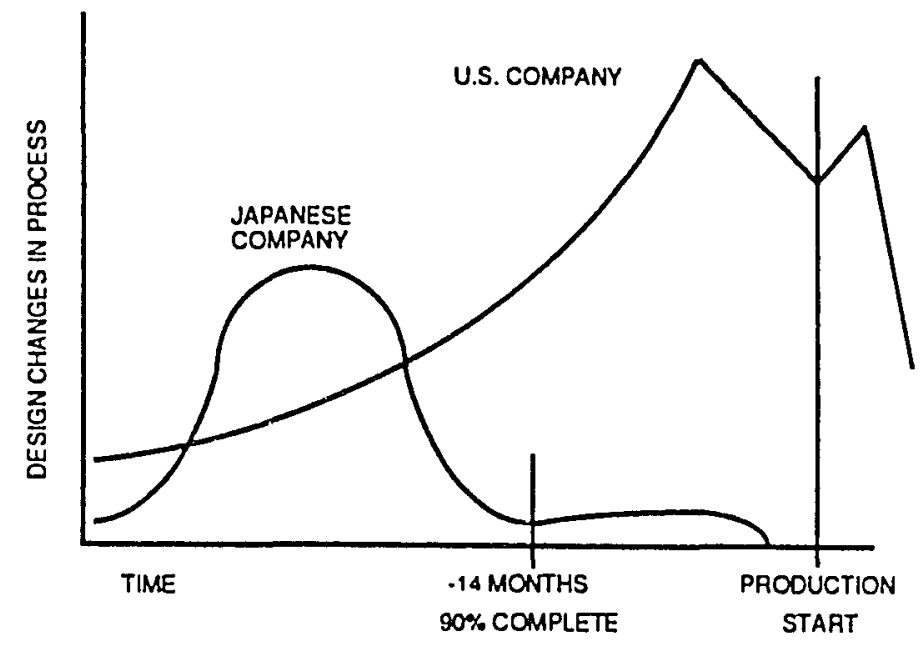

Figure 10. Typical design change process--Aisen Warner. $(67,27)$ 


\section{TOYOTA PRODUCTION STARTUP PROBLEMS}

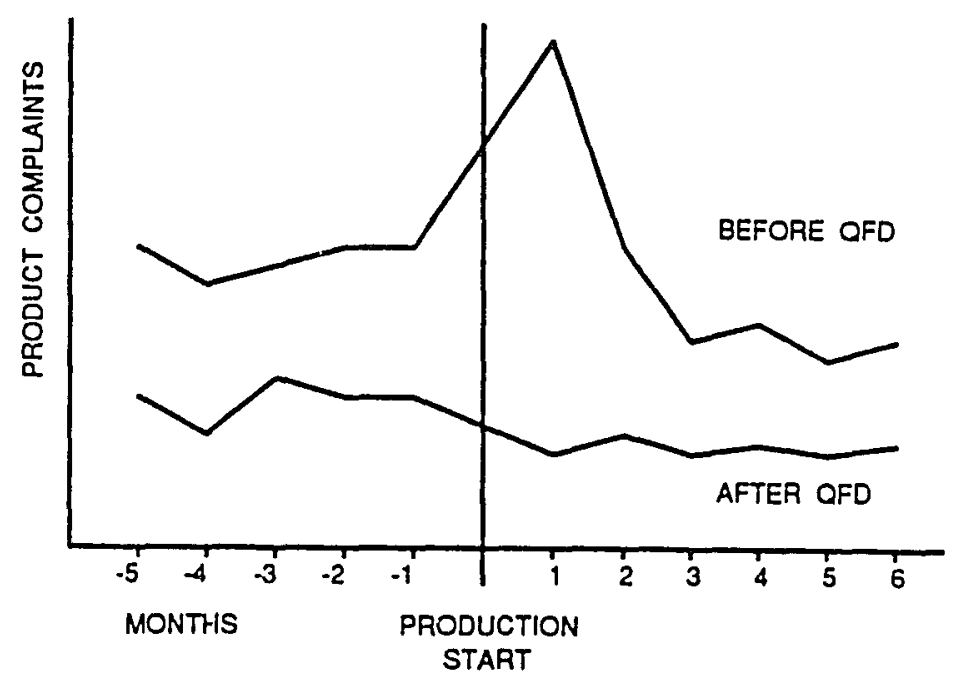

After implementing Q.F.D., Toyota found that the level of problems was reduced while the surge at startup was eliminated. Quality Function Deployment helped eliminate the surge by causing problems to be anticipated before they happened, allowing preventive action to be taken instead of corrective action.

Certainly Toyota had some startup problems, but the magnitude was substantially reduced.

Figure 11. Q.F.D. startup problem reduction-Toyota. $(67,29)$ 


\section{TOYOTA PRODUCTION STARTUP COSTS}

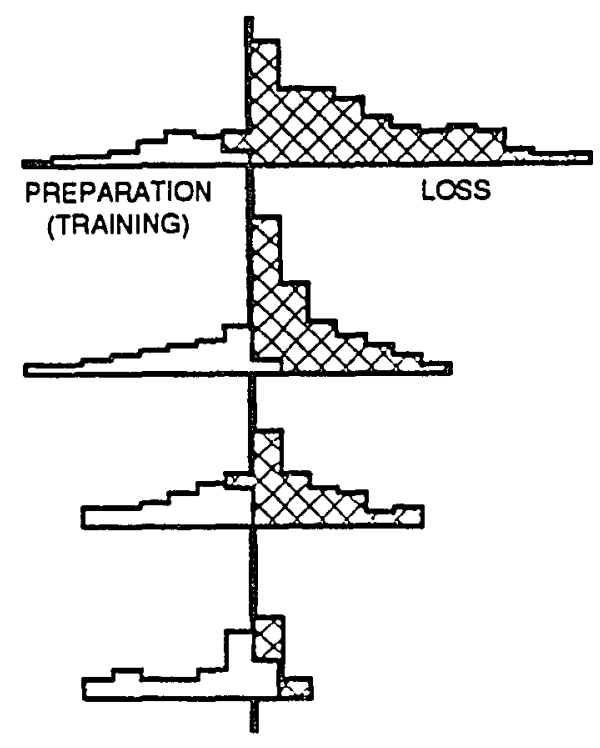

JAN 1977

INDEX $=100$

OCT 1977

INDEX $=80$

NOV 1982

INDEX $=62$

APRIL 1984

INDEX $=39$

PRODUCTION START

The shaded area represents the costs incurred after production startup. The mindset at Toyota was that these costs were losses which should be driven to zero. The unshaded region represents preparatory costs, principally operator training.

If we take the total cost in 1977 (when Toyota was just starting Q.F.D.), as an index of 100, we see that by 1984 Toyota had experienced a $61 \%$ reduction in startup costs.

Figure 12. Q.F.D. startup costs reduction-Toyota. $(67,30)$ 
development of the customer's needs and wants and the producer's production processes and controls are referred to as definitely improving customer satisfaction and leading to increased sales and market share over old methods. Thirtytwo references referred to this topic $(1 ; 2 ; 3 ; 4 ; 5 ; 7 ; 8$; $11 ; 16 ; 19 ; 21 ; 22 ; 23 ; 24 ; 27 ; 28 ; 29 ; 35 ; 37 ; 38 ; 39 ; 45$; $47 ; 49 ; 50 ; 53 ; 56 ; 59 ; 64 ; 67 ; 68 ; 70 ; A ; E ; P)$. Also, the historical success of the Japanese companies who employ Q.F.D. tends to support this model element as a potential Q.F.D. outcome.

Improved Product's Cost (OUT2). A very large body of the 1 iterature discussed various product cost savings, including reduced engineering change notices and reduced start up costs. In addition, Q.F.D.'s clearly stated design interrelationships and trade-offs may be utilized to reduce the product's direct costs. Also mentioned is that customer returns and warranty costs are reduced when compared to the prior practices. The literature sources simply stated that the product's cost should be reduced. Other than Figures 10,11 , and 12 , no specific data were referred to or found. The references included $1 ; 2 ; 3 ; 4 ; 7 ; 8 ; 16 ; 22 ; 23 ; 24$; $27 ; 28 ; 29 ; 35 ; 37 ; 38 ; 39 ; 45 ; 47 ; 49 ; 53 ; 59 ; 64 ; 67 ; 68$. Academics, experts, and practitioners agreed that improved product's cost is a potential Q.F.D. outcome.

Improved Product's Time-to-Market (OUT3). In regard to the four potential Q.F.D. outcomes, the fewest number of 
sources referred to Q.F.D. reducing the product's time-tomarket. King $(37 ; 38)$, in particular, insisted that a product's time-to-market will be significantly reduced (by half) and references Akao $(2 ; 3 ; 4)$ for support. Other references stated that while the upfront designing and planning time is increased, the subsequent pilot runs and production debugging time is reduced. With the debugging time reduced, more than the upfront time is increased; the overall time-to-market is reduced. Also mentioned is that the initial Q.F.D. chart development process may take longer, but once the initial documentation has occurred, this insures that subsequent model changes will be moved more rapidly to market. Academics, experts, and practitioners concurred that improved product's time-to-market is a potentia1 Q.F.D. outcome $(1 ; 16 ; 22 ; 23 ; 24 ; 28 ; 29 ; 35 ; 45$; $49 ; 53 ; 64 ; 67 ; 68 ; 70 ; \mathrm{A} ; \mathrm{E} ; \mathrm{P})$.

Improved Product's Communications and Documentation Effort (OUT4). Q.F.D. communicates the customer's needs and wants, the competitive assessments, the design trade-offs made, and the strategic marketing plan to all team members. Q.F.D. also documents these same items on its charts. The following sources referenced the communications and documentations effort and they simply stated that it is improved with Q.F.D.: $1 ; 2 ; 8 ; 11 ; 12 ; 16 ; 19 ; 21 ; 22 ; 23 ; 24 ; 28$; $29 ; 37 ; 45 ; 47 ; 50 ; 53 ; 56 ; 62 ; 64 ; 67$. Experts and practitioners agreed that improved product's communications and 
documentation effort is a potential Q.F.D. outcome. Academics did not address the topic.

\section{CONTRIBUTION TO THE LITERATURE}

The literature search and reviews contributed to the compilation of the known published English language body of literature concerning Q.F.D. To date, no known descriptive or prescriptive implementation model of Q.F.D. exists. This dissertation identified an implementation model framework and added specific model elements to construct an initial descriptive Q.F.D. implementation model. This model will aid researchers and practitioners. Researchers will be able to further develop and test theories about Q.F.D. implementation based on this or a similar model. Practitioners will be able to adapt their implementation strategies and practices to improve the overall quality and productivity of Q.F.D. based upon this or a similar model. This initial descriptive implementation model was researched as discussed in Chapter III, Design of the Research.

\section{SUMMARY}

A description of the dissertation's Q.F.D. literature search, new product introduction literature review, and socio-technical processes/situations analys is literature review was presented. A list of the known English language material on Q.F.D. was compiled. Recognizing a lack of a 
Q.F.D. implementation model, an appropriate socio-technical analysis methodology, known as Multiple Perspectives, was utilized to construct a Q.F.D. implementation model framework. Using literature sources and academic, expert, and practitioner inputs, specific model elements were developed and described. By synthesizing the model elements into the implementation model framework, an initial descriptive Q.F.D. implementation model was completed. These contributions were noted. The Q.F.D. implementation model was researched as discussed next in Chapter III, Design of the Research, and Chapter IV, Findings of the Research. Chapter $V$ then presents the dissertation's Conclusions, Contributions, Future Research Recommendations and Summary of the Research. Finally, references and supporting appendices are presented. 
CHAPTER III

DESIGN OF THE RESEARCH

INTRODUCTION

In order to meet the research objective of providing information about Q.F.D., four research questions were raised. They were:

1. What are the variables which affect Q.F.D.?

2. What are the outcomes from using Q.F.D.?

3. What relationships exist between Q.F.D. variables and outcomes?

4. What guidelines may be offered to practitioners of Q.F.D.?

From the literature search, literature reviews, and inputs from academics, experts, and practitioners, an initial descriptive Q.F.D. implementation model of Q.F.D. variables and outcomes was developed. This implementation model identifies potential Q.F.D. variables and outcomes which needed to be tested for confirmation. Also potential relationships between Q.F.D.'s variables and outcomes needed to be explored along with some guidelines for Q.F.D. practitioners. 
The following sections describe the specific research hypotheses that were tested. Next, the research methodology that was used to test these hypotheses is described. A summary of this chapter and the balance of the dissertation is then presented.

\section{RESEARCH HYPOTHESES}

The initial Q.F.D. implementation model identified 17 potential Q.F.D. variables and four potential Q.F.D. outcomes. Each variable may potentially affect each outcome. For each variable, there are four research hypotheses using $V_{i}$ and $O_{i}$ to symbolize distinct variables and outcomes; the first three research hypotheses are shown below:

$$
\begin{aligned}
\mathrm{H}_{1}=\mathrm{HV}_{1} \mathrm{O}_{1}= & \begin{array}{l}
\text { Q.F.D. Chart Building Methodology } \\
\text { significantly improved the product's } \\
\text { design. }
\end{array} \\
\mathrm{H}_{2}=\mathrm{HV}_{2} \mathrm{O}_{1}= & \text { Q.F.D. Chart Size/Complexity signifi- } \\
& \text { cantly improved the product's design. } \\
\mathrm{H}_{3}=\mathrm{HV}_{3} \mathrm{O}_{1}= & \text { Q.F.D. Customer Information Availability } \\
& \begin{array}{l}
\text { significantly improved the product's } \\
\text { design. }
\end{array}
\end{aligned}
$$

The last three of this set of the research hypotheses are shown below:

$$
\begin{aligned}
\mathrm{H}_{66}=\mathrm{HV}_{15 \mathrm{O}_{4}=} & \text { Individuals' Training and Experience in } \\
& \text { Q.F.D. significantly improved the } \\
& \text { product's communications and documenta- } \\
& \text { tion effort. } \\
\mathrm{H}_{67}=\mathrm{HV}_{16} \mathrm{O}_{4}= & \text { Individuals' Personal Power signifi- } \\
& \text { cantly improved the product's communica- } \\
& \text { tions and documentation effort. }
\end{aligned}
$$




$$
\begin{aligned}
\mathrm{H}_{68}=\mathrm{HV}_{17 \mathrm{O}_{4}=} & \text { Individuals' Available Work Time for } \\
& \text { Q.F.D. significantly improved the } \\
& \text { Product's communications and documenta- } \\
& \text { tion effort. }
\end{aligned}
$$

These 68 specific research hypotheses addressed the first research question of "What are the variables which affect Q.F.D.?" In order to address the second research question of "What are the outcomes from using Q.F.D.?" the following four research hypotheses are specified:

$$
\begin{aligned}
\mathrm{H}_{69}= & \text { Q.F.D. significantly improved the product's } \\
& \text { design compared to the prior methodology. } \\
\mathrm{H}_{70}= & \text { Q.F.D. significantly reduced the product's cost } \\
& \text { compared to the prior methodology. } \\
\mathrm{H}_{71}= & \text { Q.F.D. significantly reduced the product's time- } \\
& \text { to-market compared to the prior methodology. } \\
\mathrm{H}_{72}= & \text { Q.F.D. significantly improved the product's } \\
& \text { communications and documentation effort compared } \\
& \text { to the prior methodology. }
\end{aligned}
$$

The third research question of "What relationships exist between Q.F.D. variables and outcomes?" is addressed by the following 21 research hypotheses. The four research hypotheses dealing with relationships between Q.F.D. variables are:

$\mathrm{H}_{73}=$ There is no significant difference between the Q.F.D. variables' affect on improving the product's design.

$\mathrm{H}_{74}=$ There is no significant difference between the Q.F.D. variables' affect on reducing the product's cost.

$\mathrm{H}_{75}=$ There is no significant difference between the Q.F.D. variables' affect on reducing the product's time-to-market. 
$\mathrm{H}_{76}=$ There is no significant difference between the Q.F.D. variables' affect on improving the product's communication and documentation effort.

The first and last of the 17 research hypotheses dealing with relationships between Q.F.D. outcomes are:

$\mathrm{H}_{77}=$ There is no significant difference between the Q.F.D. outcomes for the Q.F.D. Chart Building Methodology variable.

$\mathrm{H}_{93}=$ There is no significant difference between the Q.F.D. outcomes for the Individual's Available Work Time for Q.F.D. variable.

To address the fourth research question of "What guidelines may be offered to practitioners of Q.F.D.?" the six most directly measurable (ratio data) Q.F.D. variables were utilized to develop the following six research hypotheses:

$\mathrm{H}_{94}=$ The larger the number of items in the Q.F.D. interrelationship chart, the less positive the outcomes will be from using Q.F.D.

$\mathrm{H}_{95}=$ The higher the availability of Q.F.D.'s customer information, the more positive the outcomes will be from using Q.F.D.

$\mathrm{H}_{96}=$ The higher the availability of Q.F.D.'s competitive information, the more positive the outcomes will be from using Q.F.D.

$\mathrm{H}_{97}=$ The larger the Q.F.D. team size, the more positive the outcomes will be from using Q.F.D.

$\mathrm{H}_{98}=$ The higher the Q.F.D. Level/Phase completed, the more positive the outcomes will be from using Q.F.D.

$\mathrm{H}_{99}=$ The longer the Q.F.D. project time, the more positive the outcomes will be from using Q.F.D.

These specific 99 research hypotheses were tested so that the four research questions could be answered. The 
research methodology used to test these 99 research hypotheses is described next.

\section{RESEARCH METHODOLOGY}

As noted in Chapter II, Q.F.D. is a socio-technical process, and a Multiple Perspectives approach was appropriately used to develop and organize what the Q.F.D. implementation model's potential Q.F.D. variables were. Multiple Perspectives also may be used to improve how the research examines Q.F.D. Different methods for examining technical, organizational, and personal variable groups may be necessary and even more appropriate than one standard method.

The dissertation's research methodology included the use of a standard technical assessment process as well as an organization and personal assessment process. Each of these assessment processes, as well as their integration, is described in turn.

Technical Assessment

The dissertation's research was ex post facto and social-psychological in nature. Therefore, psychological principles of measurement methodology and data collection and statistical principles for data analysis were used.

Measurement Methodology. Psychological principles of measurement were used to design an assessment instrument $(14 ; 15 ; 20 ; 36 ; 48 ; 51 ; 58 ; 61)$. A questionnaire based on 
the 99 research hypotheses was developed. Its developmental process is shown in Figure 13 and described below.

From the first 68 research hypotheses, representative measures were constructed. These measures use a five-point interval Likert scale to enable respondents to indicate how the potential Q.F.D. variable affected each Q.F.D. outcome. A typical example is shown below:

In regard to this

Q.F.D. project:

How did customer information availability affect the Q.F.D. product design?
How Affected (circle your answer)

\begin{tabular}{|c|c|c|c|c|}
\hline $\begin{array}{c}1 \\
\text { Strongly }\end{array}$ & $\begin{array}{c}2 \\
\text { Impaired }\end{array}$ & $\begin{array}{l}3 \\
\text { No }\end{array}$ & $\begin{array}{c}4 \\
\text { Improved }\end{array}$ & $\stackrel{5}{\text { St rongly }}$ \\
\hline $\begin{array}{l}\text { Impaired } \\
\text { Design }\end{array}$ & Design & Affect & Design & $\begin{array}{l}\text { Improved } \\
\text { Design }\end{array}$ \\
\hline
\end{tabular}

These 68 measures/questions were arranged and formatted according to sociological survey methods (20). These 68 measures/questions comprise Section I of the Q.F.D. questionnaire and are shown in Appendix $C$.

Section II of the Q.F.D. questionnaire is comprised of measures constructed for research hypotheses 69 through 72 . These measures compare the Q.F.D. implementation model's four Q.F.D. outcomes to a prior product design and introduction methodology. These measures/questions also utilize a five-point interval Likert scale as was discussed above. Section II of the Q.F.D. questionnaire is shown in Appendix C. No additional measures are required to test hypotheses 73 through 93. 


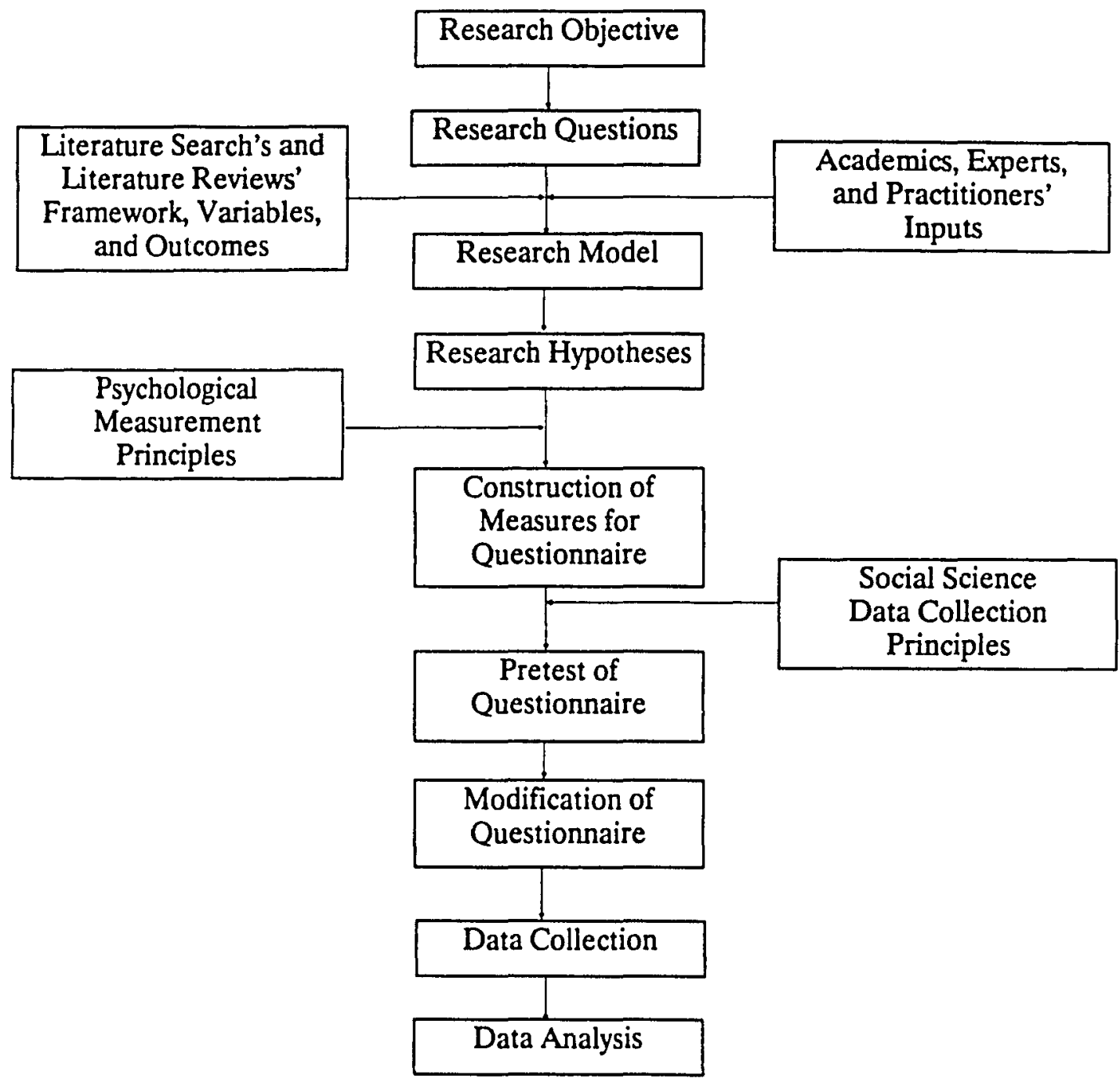

Figure 13. Questionnaire's development process. 
Finally, measures/questions were constructed for research hypotheses 94 through 99. These questions collected ratio data on six of the 17 potential Q.F.D. variables. These measures/questions did not utilize Likert scales, but rather were of a direct nature, such as, What Q.F.D. Level/ Phase did your project team complete? Numerical answers had to be provided (i.e., Level/Phase 1 through 4). These six ratio measures comprise Section III of the Q.F.D. questionnaire and are shown in Appendix $C$.

The initial Q.F.D. questionnaire was pretested at a Q.F.D. practicing company not involved with the automotive company being studied. After administering the questionnaire to seven Q.F.D. team leaders, the appropriateness of the items, word clarity, ease of understanding, and completion time were specifically questioned. The questionnaire's content validity was also questioned through this same faceto-face exchange. Suggested improvements were considered. Several word and sentence improvements were made to the questionnaire.

Content validity is the agreement that the measures represent the items being measured. Content validity is generally assessed by the researcher's and measurement subjects' agreement on the content of the measurement instrument. The dissertation's research questionnaire and model are based on a specific literature review with extensive inputs from academics, experts, and practitioners. In 
addition, the Q.F.D. questionnaire was refined with inputs from pretest subjects. Therefore, the measurement instrument was deemed to be content valid and ready for the data collection step.

Data Collection. Q.F.D. deals with customer information, marketing strategies, competitive assessment, and new product designs at a minimum. Thus, companies are very concerned about confidentiality of information when being questioned about their Q.F.D. projects. The prior stated boundaries of the dissertation reflect these concerns by limiting the study to one of the major American automotive manufacturers. This company agreed to supply information on their Q.F.D. projects. Approximately 100 Q.F.D. project teams had been formed by this company. The dissertation's technical assessment used census data collection to collect the necessary research data. The census data collection utilized almost the entire population of the Q.F.D. project team leaders. Sampling of the population was not conducted. The Total Design Method was used to construct, administer, and collect the research data (20). The dissertation utilized the Total Design Method's following four steps for data collection:

1. Initial mailing: Cover letter and Q.F.D. questionnaire

2. One-week follow-up: Postcard reminder

3. Three-week follow-up: Second letter and replacement Q.F.D. questionnaire 
4. Seven-week follow-up: Personal phone call and third letter and replacement Q.F.D. questionnaire

The dissertation's Q.F.D. questionnaire is shown in Appendix C. The associated Q.F.D. questionnaire's other mailing documents are shown in Appendix D. Completed questionnaires were mailed directly back to the researcher to ensure confidentiality. A summary of the dissertation's research findings and conclusions was mailed to the company's Corporate Q.F.D. Coordinator for dispersion to the Q.F.D. project team leaders.

Some Q.F.D. project team leader non-respondents were interviewed via telephone to examine for any non-response bias. A high response rate (70\% or higher) was expected due to the past responses associated with use of the Total Design Method (20) and due to the respondents' interest in Q.F.D.

Data Analysis. Reliability is the ability to produce consistent scores. The test-retest, split-halves, alternative form, and internal consistency methods represent the generally accepted means for assessing reliability. Testing complications and result ambiguities have led researchers and academics to recommend the use of the internal cons istency method over the test-retest, split-halves, and alternative form methods $(14 ; 36 ; 51 ; 52 ; 55)$.

This dissertation used the internal consistency method to determine the measure's reliability. The reliability was 
estimated by calculating a reliability coefficient. Cronback's alpha is the generally accepted reliability coefficient in use and was used in the dissertation's reliability assessment. A reliability assessment was done after the data collection step was completed. Individual measures may be considered for elimination to improve the reliability coefficient. Typically for beginning research, alphas of 0.5-0.6 have been used. The dissertation used 0.5-0.6 for its alpha range for assessing the reliability of the measuring instrument. An alpha of 0.7 was hoped for and has been sufficient for modestly reliable ongoing research measuring instruments in the past $(13 ; 36 ; 51 ; 52 ; 55)$.

Measurements are valid if they measure what it is intended for them to measure. Three different types of validity are generally examined: content validity, criterion-related validity, and construct validity. The measurement instrument was earlier deemed to be content valid. Criterion-related validity (also known as external or predictive validity) is the extent to which a measuring instrument is related to an independent measure of the relevant criterion. Since there does not exist at present any known independent criterion, criterion-related validity cannot be assessed.

Construct validity is the degree to which the instrument measures the theoretical concept it is purported to measure. Evidence is ordinarily accumulated through 
repeated use of the instrument over a period of time. Since this is the first application of the measurement instrument, construct validity cannot be assessed as yet.

The data were entered into a computer database so that statistical calculations were facilitated. The statistical analysis software package SYSTAT 5.1 was utilized for the dissertation's statistical calculations. The data were organized and entered by each Q.F.D. project team leader's individual question response. The software package was then utilized to calculate the appropriate statistical measures shown and described next.

Basic descriptive statistics were calculated for the first set of 68 research hypotheses. A histogram was also constructed for each of these 68 research hypotheses (see Table I).

Basic descriptive statistics were calculated for the second set of four research hypotheses. A histogram was also constructed for each of these four research hypotheses (see Table II).

A two-, three- and four-level factor analysis of the 17 Q.F.D. potential variables was completed for each of the four outcomes. These factor analyses were used to compare/contrast to the research model's Technical, Organizational and Personal factors. 
TABLE I

EMPTY ILLUSTRATION OF POTENTIAL Q.F.D. VARIABLES' DESCRIPTIVE STATISTICS

\begin{tabular}{|c|c|c|c|c|c|c|c|c|c|c|c|c|c|c|c|}
\hline \multirow[b]{3}{*}{$\begin{array}{l}\text { Vari- } \\
\text { ihlo }\end{array}$} & \multirow[b]{3}{*}{$\begin{array}{l}\text { Variable } \\
\text { Descriptim }\end{array}$} & \multicolumn{14}{|c|}{ Qur came } \\
\hline & & \multicolumn{7}{|c|}{ Design } & \multicolumn{7}{|c|}{ Cost } \\
\hline & & $\begin{array}{c}\text { Resp. } \\
\text { Nh. }\end{array}$ & $\begin{array}{l}\text { Resp. } \\
\text { Mean }\end{array}$ & $\begin{array}{l}\text { Resp. } \\
\text { S.D. }\end{array}$ & $\begin{array}{l}\text { Skew- } \\
\text { ness }\end{array}$ & $\begin{array}{l}\text { Kurt- } \\
\text { osis }\end{array}$ & $\begin{array}{l}\text { Proba- } \\
\text { bility }\end{array}$ & $\begin{array}{l}\text { Resp. } \\
\text { Median }\end{array}$ & $\begin{array}{c}\text { Resp. } \\
\text { No. }\end{array}$ & $\begin{array}{l}\text { Resp. } \\
\text { Mean }\end{array}$ & $\begin{array}{l}\text { Resp. } \\
\text { S.D. }\end{array}$ & $\begin{array}{l}\text { Skew- } \\
\text { ness }\end{array}$ & $\begin{array}{l}\text { Kurt- } \\
\text { osis }\end{array}$ & $\begin{array}{l}\text { Proba- } \\
\text { bility }\end{array}$ & $\begin{array}{l}\text { Resp. } \\
\text { Mediant }\end{array}$ \\
\hline $\begin{array}{l}T 1 \\
12 \\
11 \\
T / 4 \\
15\end{array}$ & $\begin{array}{l}\text { Chart byilding } \\
\text { Chart Size } \\
\text { Customer Info. } \\
\text { Compertitive Info. } \\
\text { Accurat e be ight s }\end{array}$ & & & & & & & & & & & & & & \\
\hline $\begin{array}{l}(x) \\
117 \\
19 \\
114 \\
1111 \\
1111 \\
1112 \\
1113\end{array}$ & 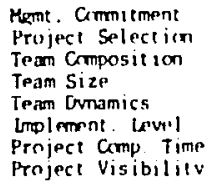 & & & & & & & & & & & & & & \\
\hline \multirow[t]{2}{*}{ 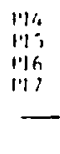 } & $\begin{array}{l}\text { Personal Commit } \\
\text { Training } \\
\text { Personal Power } \\
\text { Available Time }\end{array}$ & & & & & & & & & & & & & & \\
\hline & & \multicolumn{7}{|c|}{ Time } & \multicolumn{7}{|c|}{ Communications } \\
\hline ini- & $\begin{array}{l}\text { Variable } \\
\text { Descriptim }\end{array}$ & $\begin{array}{l}\text { Resp. } \\
\text { Non. }\end{array}$ & $\begin{array}{l}\text { Resp. } \\
\text { Mean }\end{array}$ & $\begin{array}{l}\text { Resp. } \\
\text { S.D. }\end{array}$ & $\begin{array}{l}\text { Skewr } \\
\text { ness }\end{array}$ & $\begin{array}{l}\text { Kurt- } \\
\text { osis }\end{array}$ & $\begin{array}{l}\text { Proba- } \\
\text { bility }\end{array}$ & $\begin{array}{l}\text { Resp. } \\
\text { Hedian }\end{array}$ & $\begin{array}{l}\text { Resp. } \\
\text { No. }\end{array}$ & $\begin{array}{l}\text { Resp. } \\
\text { Hean }\end{array}$ & $\begin{array}{l}\text { Resp. } \\
\text { S.D. }\end{array}$ & $\begin{array}{l}\text { Shew } \\
\text { ness }\end{array}$ & $\begin{array}{c}\text { Kurt- } \\
\text { osis }\end{array}$ & $\begin{array}{l}\text { Proba- } \\
\text { bility }\end{array}$ & $\begin{array}{l}\text { Resp. } \\
\text { Hedian }\end{array}$ \\
\hline $\begin{array}{l}11 \\
\because: \\
13 \\
1: 4\end{array}$ & $\begin{array}{l}\text { Ohart Buildine } \\
\text { Cart Size } \\
\text { Oustamer Info. } \\
\text { Compet itive Info. } \\
\text { Accurat e te ights }\end{array}$ & & & & & & & & & & & & & & \\
\hline 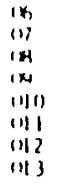 & 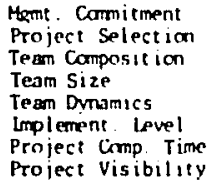 & & & & & & & & & & & & & & \\
\hline $\begin{array}{l}114 \\
1115 \\
116 \\
1110\end{array}$ & $\begin{array}{l}\text { Personal Commit. } \\
\text { Training } \\
\text { Personal power } \\
\text { Available Tume }\end{array}$ & & & & & & & & & & & & & & \\
\hline
\end{tabular}


TABLE II

EMPTY ILLUSTRATION OF POTENTIAL Q.F.D. OUTCOMES' DESCRIPTIVE STATISTICS

\begin{tabular}{|c|c|c|c|c|c|c|c|c|}
\hline \multirow[b]{2}{*}{$\begin{array}{l}\text { Out- } \\
\text { come }\end{array}$} & \multirow[b]{2}{*}{$\begin{array}{c}\text { Outcame } \\
\text { Description }\end{array}$} & \multicolumn{5}{|c|}{ Comparison to Prior Non-Q.F.D. } & \multicolumn{2}{|c|}{ Experience } \\
\hline & & $\begin{array}{l}\text { Resp. } \\
\text { No. }\end{array}$ & $\begin{array}{l}\text { Resp. } \\
\text { Mean }\end{array}$ & $\begin{array}{l}\text { Resp. } \\
\text { S.D. }\end{array}$ & $\begin{array}{l}\text { Skew- } \\
\text { ness }\end{array}$ & $\begin{array}{l}\text { Kurt- } \\
\text { osis }\end{array}$ & $\begin{array}{l}\text { Proba- } \\
\text { bility }\end{array}$ & $\begin{array}{l}\text { Resp. } \\
\text { Median }\end{array}$ \\
\hline OUTI & Impr. Design & & 1 & & & & & \\
\hline OUT2 & Impr. Cost & & & & & & & \\
\hline OUT3 & Impr. Time & & & & & & & \\
\hline OUT4 & Impr. Cormm. & & & & & & & \\
\hline
\end{tabular}


TABLE III

EMPTY ILLUSTRATION OF RELIABILITY

ASSESSMENT SUMMARY

\begin{tabular}{|c|c|c|c|c|}
\hline Factor & Outcome & $\begin{array}{l}\text { No. Scale } \\
\text { Items }\end{array}$ & $\begin{array}{l}\text { Inter-Item } \\
\text { Correlation Ave. }\end{array}$ & $\begin{array}{c}\text { Coefficient } \\
\text { Alpha }\end{array}$ \\
\hline Technical & Impr. Design & & & \\
\hline Organiz. & Impr. Design & & & \\
\hline Personal & Impr. Design & & & \\
\hline Technical & Impr. Cost & & & \\
\hline Organiz. & Impr. Cost & & & \\
\hline Personal & Impr. Cost & & & \\
\hline Technical & Impr. Time & & & \\
\hline Organiz. & Impr. Time & & & \\
\hline Personal & Impr. Time & & & \\
\hline Technical & Impr. Comm. & & & \\
\hline Organiz. & Impr. Comm. & & & \\
\hline Personal & Impr. Comm. & & & \\
\hline
\end{tabular}

The reliability coefficients were calculated for the research model's factor groupings for each of the four outcomes (see Table III).

The pertinent statistics from Table I were used to conduct Multivariate Analysis of Variance (MANOVA) analyses for research hypotheses 73 through 93 . These MANOVA analyses allowed statements to be made concerning the Q.F.D. variables' and outcomes' relationships (see Table IV).

The ratio data for research hypotheses 94 through 99 were collected in Section III of the research questionnaire. These ratio data were plotted on the $X$ coordinate axis of 
box and whiskers $X-Y$ graphs. The Q.F.D. projects' median values for each of the four Q.F.D. outcomes were plotted on the $\mathrm{Y}$ coordinate axis of these box and whiskers graphs. Guidelines for Q.F.D. practitioners were developed based on the 24 graphed relationships (six variables each with four outcomes) (see Figure 14).

TABLE IV

EMPTY ILLUSTRATION OF Q.F.D. VARIABLES'

AND OUTCOMES' MANOVA SUMMARY

\begin{tabular}{|c|c|c|c|c|c|}
\hline $\begin{array}{l}\text { Variable/ } \\
\text { Outcome }\end{array}$ & $\begin{array}{l}\text { Variable/Outcome } \\
\text { Description }\end{array}$ & $\begin{array}{l}\text { Wilks' } \\
\text { Lambda }\end{array}$ & $\underset{\text { Statistic }}{\mathrm{F}}$ & $\begin{array}{l}\text { Degrees of } \\
\text { Freedom }\end{array}$ & $\begin{array}{l}\text { Proba- } \\
\text { bility }\end{array}$ \\
\hline
\end{tabular}

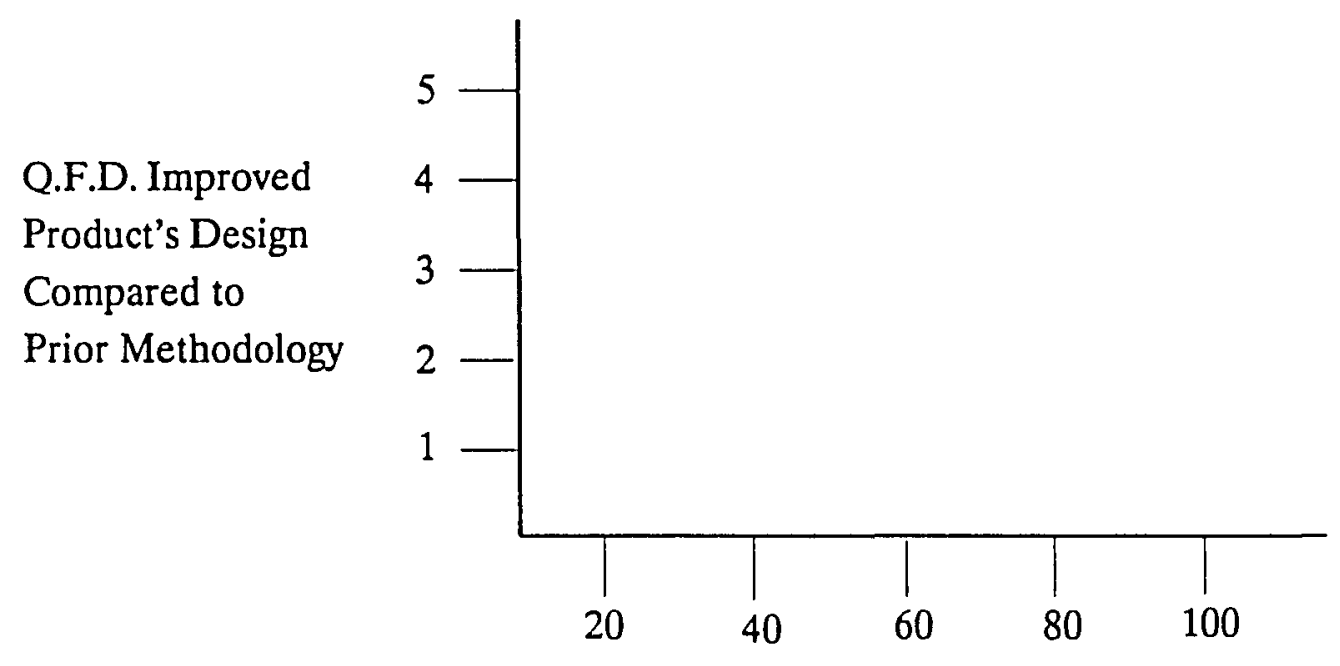

Custorner Information Availability (\%)

Figure 14. Q.F.D. practitioner's guidelines graph example. 
Organizational Assessment

A technical assessing process is not necessarily the process most suited for examining organizational concerns. Multiple Perspectives calls for different paradigms to be used in the assessing process (not just the typical objective/quantifiable technical assessing process). If the reader is unfamiliar with Multiple Perspectives, a brief overview is presented in Appendix B.

Measurement Methodology. An organizational assessment is conducted from the point of view of affected and affecting organizations. The relevant organizations involved with the Q.F.D. project were identified. Due to the dissertation's economic and time considerations, a sample size of three Q.F.D. projects was selected. The company's Corporate Q.F.D. Coordinator was asked to confirm selection of one outstanding/successful project, one typical project, and one difficult/unusual project.

Multiple Perspectives encourages the use of unstructured interviews of prominent/key persons involved in the situation being studied. Interviewees were listened to so as to identify the various organizations' support of or opposition to Q.F.D. and any coalitions and standard operating procedures that may have developed in regard to the Q.F.D. project.

Data Collection. While an interviewing team is preferred, due to the dissertation's economic constraints a 
single interviewer was selected. A competent interviewer should be aware of the technical, organizational, and personal perspectives within the Multiple Perspectives approach. Further, a competent interviewer should have experience in these perspectives and, most importantly, be a good listener. The selected interviewer possessed these necessary characteristics (design and process engineering background; first, middle, and top level managerial background; personal Q.F.D. experience; no employment tie to the company studied; and peer-verified good listening skills).

The interviewer conducted face-to-face, qualitative, in-depth interviews concerning the three previously selected Q.F.D. projects. At minimum, each team leader, one prominent/key team member (identified by the team leader), and one impacted (but non-team member) decision maker/manager were interviewed. Other personnel identified in these interviews also were subsequently interviewed as time permitted.

The 16 Guidelines for Users of Multiple Perspectives and the Guidelines for Implementation of Organizational and Personal Perspectives were followed (41). Open-ended questions were used to let the interviewees lead the interviewer through their Q.F.D. experiences and develop an organizational assessment of their Q.F.D. project. See Appendix E for some of the potential questions that may have been used during the interviewing. 
Data Analysis. Qualitative interpretations of the interviews were done. Brief summaries of the various organizations' postures and positions were constructed and compared to an ideal project scenario for each of the three Q.F.D. projects.

Personal Assessment

Neither a technical nor an organizational assessment tends to be able to capture intuition, charisma, leadership, and personal self-interests. These items often play central roles in policy and decision making.

Measurement Methodology. A personal assessment is conducted from the point of view of affected and affecting individuals. Utilizing the same three Q.F.D. projects as the organizational assessment, the same key individuals were investigated. "Powers behind the throne," "puppeteers pulling the strings," "information gatekeepers," and "dynamic leaders" were hopefully identified. Interviewees were listened to so as to identify these people, their support or opposition to Q.F.D. and any of their intuitions, leadership qualities, and self-interests they may have demonstrated during the Q.F.D. project.

Data Collection. Personal assessment data were collected in a manner similar to the organizational assessment data collection. The same key individuals were investigated as in the organizational assessment. However, different 
open-ended questions may have been used to let the interviewees lead the interviewer through their personal Q.F.D. experiences and develop a personal assessment of their Q.F.D. project. See Appendix E for some potential questions that may have been asked during the interviews.

Data Analysis. Qualitative interpretations of the interviews were done. Brief descriptions of the various key individuals on the three projects were constructed. These brief descriptions were utilized to capture the essence of the personal assessment data.

\section{Integration of Assessments}

Each separate perspective--technical, organizational, and personal--is presented in the Findings of the Research chapter. Additionally, the perspectives were examined to see if they work at cross purposes or if they are complementary (cross-cuing). There is a large risk in extrapolating the three Q.F.D. projects' organizational and personal assessments to the approximately 100 Q.F.D. projects. There is also a large risk in integrating the three assessments together due to their selection criteria (Outstanding/Successful, Typical, Difficult/Unusual). Therefore, only 1 ists of the similarities and discontinuities between the assessments were developed. 
SUMMARY

The research objective and questions were developed into 99 specific research hypotheses. The dissertation's research methodology was described as one using a Multiple Perspectives approach. This approach used three assessment processes-technical, organizational, and personal.

The technical assessment utilized the research hypotheses and developed a measurement instrument (questionnaire). This questionnaire was administered to approximately all Q.F.D. project team leaders via the Total Design Method. This multi-step method has been demonstrated to obtain very high response rates. Descriptive statistics, histograms, factor analyses and reliability coefficients were calculated/constructed to examine the first 72 research hypotheses. MANOVA analyses were conducted to examine the next 21 research hypotheses. Further, graphical relationships for 24 selected variable/outcome relationships were constructed to provide guidelines for Q.F.D. practitioners (to examine the last six research hypotheses).

The organizational assessment utilized one interviewer to conduct face-to-face interviews with key personnel to obtain qualitative brief summaries of various organizations' postures and positions supporting or opposing the Q.F.D. project. Three Q.F.D. projects (one successful, one 
typical, and one difficult) were assessed and compared to an ideal Q.F.D. project scenario.

The personal assessment utilized a similar measurement methodology and data collection process and the same three Q.F.D. projects as the organizational assessment. Brief personal descriptions were constructed to capture the essence of key individuals' intuitions, leadership qualities, and self-interests.

The technical, organizational, and personal assessments were examined for similarities and discontinuities. The major similarities and discontinuities were then 1 isted.

Chapter IV, Findings of the Research, is presented next, followed by Chapter V, Conclusions, Contributions, Future Research Recommendations and Summary of the Research. The dissertation's references and supporting appendices are presented last. 
CHAPTER IV

FINDINGS OF THE RESEARCH

INTRODUCTION

The appropriate data were collected and analyzed as described in Chapter III, Design of the Research. After a brief review of the research model, the findings of the technical, organizational and personal assessments are presented, as well as an integration of those assessments. The chapter is then summarized, and the balance of the dissertation is then presented.

\section{MODEL REVIEW}

The Q.F.D. implementation model consists of variables and outcomes. The 17 Q.F.D. variables are grouped into three dimensional factors (technical, organizational and personal). There are four Q.F.D. outcomes; they are a Product's Improved Design, Improved Cost, Improved Time-toMarket and Improved Communications and Documentation Effort (see Figures 8 and 9). 
TECHNICAL ASSESSMENT FINDINGS

\section{Questionnaire Response}

The American automotive company which participated in this study identified a population of 104 Q.F.D. projects. The questionnaire was prepared and mailed to the appropriate Q.F.D. team leaders/contacts. In the course of implementing the study's Total Design Methodology duplicate projects, deaths and personnel turnover were discovered which accounted for 15 Q.F.D. projects. A total of 68 questionnaires were returned for an $80 \%$ response rate.

Some nonrespondents were telephoned to examine for nonresponse bias. No apparent pattern or bias was found. Reasons for nonresponse were scattered and were stated as never received ( 1 ), lack of time (1), questionnaire too long (2), vacation (1), and wrong person (1).

With the high response and lack of nonrespondent bias, the data were deemed to be census in nature.

Q.F.D. Variables' Descriptive

Statistics and Histograms

The 17 Q.F.D. variables were examined as to their effect on the four Q.F.D. outcomes. The descriptive statistics are shown in Table $V$. The 68 individual histograms are shown in Appendix F, Questionnaire Q.F.D. Variable/Outcome Histograms. 
TABLE V

POTENTIAL Q.F.D. VARIABLES' DESCRIPTIVE STATISTICS

\begin{tabular}{|c|c|c|c|c|c|c|c|c|c|c|c|c|c|c|c|}
\hline \multirow[b]{3}{*}{$\begin{array}{l}\text { Vari- } \\
\text {.hle } \\
\end{array}$} & \multirow[b]{3}{*}{$\begin{array}{c}\text { Variahle } \\
\text { Descript im }\end{array}$} & \multicolumn{14}{|c|}{ Outcane } \\
\hline & & \multicolumn{7}{|c|}{ Design } & \multicolumn{7}{|c|}{$\cos t$} \\
\hline & & $\begin{array}{c}\text { Resp. } \\
\text { No. }\end{array}$ & $\begin{array}{l}\text { Resp. } \\
\text { Hean }\end{array}$ & $\begin{array}{l}\text { Resp. } \\
\text { S.D. }\end{array}$ & $\begin{array}{l}\text { Skew- } \\
\text { ness }\end{array}$ & $\begin{array}{l}\text { Kurt- } \\
\text { osis }\end{array}$ & $\begin{array}{l}\text { Proba- } \\
\text { bility }\end{array}$ & $\begin{array}{l}\text { Resp. } \\
\text { Hedian }\end{array}$ & $\begin{array}{l}\text { Resp. } \\
\mathrm{Nb} .\end{array}$ & $\begin{array}{l}\text { Resp. } \\
\text { Hean }\end{array}$ & $\begin{array}{l}\text { Resp. } \\
\text { S.D. }\end{array}$ & $\begin{array}{l}\text { Skew- } \\
\text { ness }\end{array}$ & $\begin{array}{l}\text { Kurt- } \\
\text { osis }\end{array}$ & $\begin{array}{l}\text { Proba- } \\
\text { bility }\end{array}$ & $\begin{array}{l}\text { Resp. } \\
\text { Median }\end{array}$ \\
\hline $\begin{array}{l}\mathrm{T1} \\
12 \\
\mathrm{T3} \\
14 \\
\mathrm{TS}\end{array}$ & $\begin{array}{l}\text { Chart Building } \\
\text { Chart Size } \\
\text { Customer Info. } \\
\text { Compet if ive Info. } \\
\text { Accurate weikhts }\end{array}$ & $\begin{array}{l}59 \\
58 \\
58 \\
58 \\
56\end{array}$ & $\begin{array}{l}3.71 \\
3.19 \\
3.50 \\
3.59 \\
3.23\end{array}$ & $\begin{array}{l}0.56 \\
0.76 \\
1.11 \\
0.94 \\
0.71\end{array}$ & $\begin{array}{l}-0.59 \\
0.16 \\
-0.62 \\
-0.64 \\
-0.06\end{array}$ & $\begin{array}{l}0.37 \\
-0.38 \\
-0.48 \\
-0.09 \\
-0.50\end{array}$ & $\begin{array}{l}0.000 \\
0.062 \\
0.001 \\
0.000 \\
0.018\end{array}$ & $\begin{array}{l}4.0 \\
3.0 \\
4.0 \\
4.0 \\
3.0\end{array}$ & $\begin{array}{l}56 \\
56 \\
55 \\
55 \\
55\end{array}$ & $\begin{array}{l}3.07 \\
2.95 \\
2.80 \\
2.96 \\
3.11\end{array}$ & $\begin{array}{l}0.53 \\
0.48 \\
0.80 \\
0.77 \\
0.46\end{array}$ & $\begin{array}{r}0.07 \\
-0.15 \\
-0.49 \\
0.06 \\
0.43\end{array}$ & $\begin{array}{r}0.48 \\
1.27 \\
-0.02 \\
0.02 \\
1.36\end{array}$ & $\begin{array}{l}0.322 \\
0.410 \\
0.070 \\
0.727 \\
0.083\end{array}$ & $\begin{array}{l}3.0 \\
3.0 \\
3.0 \\
3.0 \\
3.0\end{array}$ \\
\hline 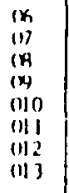 & $\begin{array}{l}\text { Memt. Commitment } \\
\text { Project Selection } \\
\text { Team Composition } \\
\text { Team Size } \\
\text { Term Dunamics } \\
\text { Imylement. Irvel } \\
\text { Priject Comp. Tume } \\
\text { Propect Visibilitv }\end{array}$ & $\begin{array}{l}57 \\
53 \\
59 \\
59 \\
58 \\
57 \\
58 \\
59\end{array}$ & $\begin{array}{l}3.33 \\
3.55 \\
3.86 \\
3.36 \\
3.74 \\
3.25 \\
3.05 \\
3.47\end{array}$ & $\begin{array}{l}1.14 \\
0.85 \\
0.88 \\
0.87 \\
0.95 \\
0.66 \\
0.74 \\
0.84\end{array}$ & $\begin{array}{r}-0.46 \\
0.04 \\
-1.11 \\
-0.27 \\
-0.84 \\
-0.68 \\
-0.08 \\
-0.19\end{array}$ & $\begin{array}{r}-0.45 \\
-0.60 \\
1.37 \\
-0.15 \\
0.30 \\
0.94 \\
-1.12 \\
-0.58\end{array}$ & $\begin{array}{l}0.031 \\
0.000 \\
0.000 \\
0.003 \\
0.000 \\
0.007 \\
0.594 \\
0.000\end{array}$ & $\begin{array}{l}3.0 \\
4.0 \\
4.0 \\
3.0 \\
4.0 \\
3.0 \\
3.0 \\
4.0\end{array}$ & $\begin{array}{l}55 \\
55 \\
56 \\
56 \\
56 \\
56 \\
55 \\
56\end{array}$ & $\begin{array}{l}3.05 \\
3.05 \\
3.20 \\
2.95 \\
3.20 \\
3.04 \\
2.87 \\
3.18\end{array}$ & $\begin{array}{l}0.59 \\
0.52 \\
0.70 \\
0.55 \\
0.64 \\
0.50 \\
0.47 \\
0.58\end{array}$ & $\begin{array}{r}-0.01 \\
0.85 \\
-0.28 \\
-0.68 \\
-0.20 \\
-0.79 \\
-0.40 \\
0.57\end{array}$ & $\begin{array}{r}-0.10 \\
3.32 \\
0.95 \\
2.40 \\
-0.65 \\
4.70 \\
1.00 \\
1.09\end{array}$ & $\begin{array}{l}0.496 \\
0.444 \\
0.040 \\
0.472 \\
0.026 \\
0.597 \\
0.051 \\
0.024\end{array}$ & $\begin{array}{l}3.0 \\
3.0 \\
3.0 \\
3.0 \\
3.0 \\
3.0 \\
3.0 \\
3.0\end{array}$ \\
\hline \multirow[t]{2}{*}{$\begin{array}{l}116 \\
\text { PIS } \\
\text { III } \\
\text { il } 7\end{array}$} & $\begin{array}{l}\text { Personal Comit. } \\
\text { Training } \\
\text { Personal Power } \\
\text { Available Time }\end{array}$ & $\begin{array}{l}59 \\
58 \\
58 \\
59\end{array}$ & $\begin{array}{l}3.76 \\
3.59 \\
3.29 \\
3.10\end{array}$ & $\begin{array}{l}0.80 \\
0.86 \\
0.84 \\
1.11\end{array}$ & $\begin{array}{l}-1.01 \\
-0.44 \\
-0.23 \\
-0.13\end{array}$ & $\begin{array}{r}0.68 \\
-0.47 \\
-0.07 \\
-1.20\end{array}$ & $\begin{array}{l}0.000 \\
0.000 \\
0.010 \\
0.484\end{array}$ & $\begin{array}{l}4.0 \\
4.0 \\
3.0 \\
3.0\end{array}$ & $\begin{array}{l}56 \\
56 \\
56 \\
55\end{array}$ & $\begin{array}{l}3.41 \\
3.27 \\
3.09 \\
2.96\end{array}$ & $\begin{array}{l}0.68 \\
0.67 \\
0.58 \\
0.67\end{array}$ & $\begin{array}{r}0.67 \\
-0.37 \\
0.56 \\
-0.34\end{array}$ & $\begin{array}{l}0.12 \\
1.36 \\
1.55 \\
0.36\end{array}$ & $\begin{array}{l}0.000 \\
0.004 \\
0.255 \\
0.687\end{array}$ & $\begin{array}{l}3.0 \\
3.0 \\
3.0 \\
3.0\end{array}$ \\
\hline & & \multicolumn{7}{|c|}{ Time } & \multicolumn{7}{|c|}{ Communications } \\
\hline $\begin{array}{l}\text { Vari- } \\
\text { ihlo }\end{array}$ & $\begin{array}{c}\text { Variable } \\
\text { Description }\end{array}$ & $\begin{array}{l}\text { Resp. } \\
\text { No. }\end{array}$ & $\begin{array}{l}\text { Resp. } \\
\text { Mean }\end{array}$ & $\begin{array}{l}\text { Resp. } \\
\text { S.D. }\end{array}$ & $\begin{array}{l}\text { Skew } \\
\text { ness }\end{array}$ & $\begin{array}{l}\text { Kurt- } \\
\text { ogis }\end{array}$ & $\begin{array}{l}\text { Proba- } \\
\text { bility }\end{array}$ & $\begin{array}{l}\text { Resp. } \\
\text { Hedian }\end{array}$ & $\begin{array}{l}\text { Resp. } \\
\text { ito. }\end{array}$ & $\begin{array}{l}\text { Reap. } \\
\text { Hean }\end{array}$ & $\begin{array}{l}\text { Resp. } \\
\text { S.D. }\end{array}$ & $\begin{array}{l}\text { Skew- } \\
\text { ness }\end{array}$ & $\begin{array}{l}\text { Kurt- } \\
\text { osis }\end{array}$ & $\begin{array}{l}\text { Proba- } \\
\text { bility }\end{array}$ & $\begin{array}{l}\text { Resp. } \\
\text { Kedian }\end{array}$ \\
\hline $\begin{array}{l}11 \\
12 \\
13 \\
11 \\
15\end{array}$ & $\begin{array}{l}\text { Oart Blde. } \\
\text { Chart Size } \\
\text { Gust mer Info. } \\
\text { Competitive Info. } \\
\text { Accurate ights }\end{array}$ & $\begin{array}{l}55 \\
55 \\
54 \\
54 \\
54\end{array}$ & $\begin{array}{l}3.22 \\
2.84 \\
2.94 \\
3.02 \\
3.20\end{array}$ & $\begin{array}{l}0.66 \\
0.74 \\
0.90 \\
0.90 \\
0.49\end{array}$ & $\begin{array}{r}0.14 \\
0.54 \\
-0.05 \\
-0.19 \\
0.44\end{array}$ & $\begin{array}{r}-0.05 \\
1.41 \\
-0.00 \\
0.02 \\
0.15\end{array}$ & $\begin{array}{l}0.017 \\
0.107 \\
0.652 \\
0.880 \\
0.004\end{array}$ & $\begin{array}{l}3.0 \\
3.0 \\
3.0 \\
3.0 \\
3.0\end{array}$ & $\begin{array}{l}58 \\
58 \\
58 \\
58 \\
57\end{array}$ & $\begin{array}{l}3.84 \\
3.03 \\
3.66 \\
3.62 \\
3.33\end{array}$ & $\begin{array}{l}0.89 \\
0.92 \\
1.04 \\
0.93 \\
0.72\end{array}$ & $\begin{array}{r}-0.88 \\
0.21 \\
-0.90 \\
-0.75 \\
0.60\end{array}$ & $\begin{array}{r}0.86 \\
-0.62 \\
0.45 \\
0.62 \\
0.25\end{array}$ & $\begin{array}{l}0.000 \\
0.776 \\
0.000 \\
0.000 \\
0.001\end{array}$ & $\begin{array}{l}4.0 \\
3.0 \\
4.0 \\
4.0 \\
3.0\end{array}$ \\
\hline 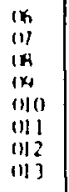 & $\begin{array}{l}\text { Memt. Commitment } \\
\text { Prnject Selection } \\
\text { Tean Composition } \\
\text { Team Stze } \\
\text { Team Dvramics } \\
\text { Implement. Level } \\
\text { Project Comp. Time } \\
\text { Project Visibility }\end{array}$ & $\begin{array}{l}54 \\
52 \\
53 \\
53 \\
53 \\
52 \\
52 \\
52\end{array}$ & $\begin{array}{l}3.13 \\
3.08 \\
3.23 \\
3.00 \\
3.19 \\
3.13 \\
3.02 \\
3.29\end{array}$ & $\begin{array}{l}0.78 \\
0.71 \\
0.64 \\
0.62 \\
0.81 \\
0.44 \\
0.64 \\
0.67\end{array}$ & $\begin{array}{r}0.50 \\
-0.11 \\
-0.23 \\
0.00 \\
0.30 \\
0.64 \\
-0.47 \\
0.41\end{array}$ & $\begin{array}{r}0.11 \\
0.91 \\
-0.65 \\
-0.35 \\
-0.34 \\
1.31 \\
0.95 \\
0.26\end{array}$ & $\begin{array}{l}0.226 \\
0.438 \\
0.013 \\
1.000 \\
0.096 \\
0.033 \\
0.830 \\
0.003\end{array}$ & $\begin{array}{l}3.0 \\
3.0 \\
3.0 \\
3.0 \\
3.0 \\
3.0 \\
3.0 \\
3.0\end{array}$ & $\begin{array}{l}57 \\
57 \\
58 \\
58 \\
57 \\
58 \\
56 \\
58\end{array}$ & $\begin{array}{l}3.58 \\
3.26 \\
3.79 \\
3.40 \\
3.63 \\
3.31 \\
3.04 \\
3.62\end{array}$ & $\begin{array}{l}0.94 \\
0.70 \\
0.77 \\
0.70 \\
0.84 \\
0.63 \\
0.69 \\
0.70\end{array}$ & $\begin{array}{r}-1.00 \\
-0.40 \\
-1.05 \\
-0.40 \\
-0.33 \\
0.53 \\
0.30 \\
0.35\end{array}$ & $\begin{array}{r}1.09 \\
0.99 \\
2.22 \\
-0.49 \\
-0.41 \\
0.39 \\
0.09 \\
-0.50\end{array}$ & $\begin{array}{l}0.000 \\
0.006 \\
0.000 \\
0.000 \\
0.000 \\
0.000 \\
0.699 \\
0.000\end{array}$ & $\begin{array}{l}4.0 \\
3.0 \\
4.0 \\
3.0 \\
4.0 \\
3.0 \\
3.0 \\
4.0\end{array}$ \\
\hline 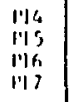 & $\begin{array}{l}\text { Personal Comit. } \\
\text { Training } \\
\text { Personal Pouer } \\
\text { Available Time }\end{array}$ & $\begin{array}{l}52 \\
53 \\
52 \\
53\end{array}$ & $\begin{array}{l}3.64 \\
3.30 \\
3.29 \\
3.13\end{array}$ & $\begin{array}{l}0.67 \\
0.64 \\
0.67 \\
0.88\end{array}$ & $\begin{array}{l}0.41 \\
0.10 \\
0.81 \\
0.09\end{array}$ & $\begin{array}{r}-0.08 \\
-0.12 \\
0.78 \\
-0.25\end{array}$ & $\begin{array}{l}0.000 \\
0.001 \\
0.003 \\
0.278\end{array}$ & $\begin{array}{l}3.0 \\
3.0 \\
3.0 \\
3.0\end{array}$ & $\begin{array}{l}58 \\
58 \\
57 \\
58\end{array}$ & $\begin{array}{l}3.66 \\
3.72 \\
3.37 \\
3.19\end{array}$ & $\begin{array}{l}0.71 \\
0.70 \\
0.70 \\
1.02\end{array}$ & $\begin{array}{r}-0.85 \\
0.11 \\
0.64 \\
-0.08\end{array}$ & $\begin{array}{r}2.08 \\
-0.46 \\
0.22 \\
-0.13\end{array}$ & $\begin{array}{l}0.000 \\
0.000 \\
0.000 \\
0.161\end{array}$ & $\begin{array}{l}4.0 \\
4.0 \\
3.0 \\
3.0\end{array}$ \\
\hline
\end{tabular}

NOTE: Probability of obtaining the mean given the hypothesized value of three. 
Discussion on Design Findings

The 17 Design questions/answers had high relative response numbers and high relative means (mean of 3 is no affect; mean above 3 is improved design). Unusual histograms were defined as having relatively high combinations of standard deviation values (about 1 or higher) and skewness or kurtosis values (about 0.4 or larger). Customer Information (T3), Management Commitment (06), and Individual's Available Work Time (P17) were identified as unusual.

T3 dealt with a very strong positive response to customer information availability affecting the design outcome. Customer information availability was stated as very important both in the questionnaire responses and additional questionnaire comments and in later interviews. Apparently customer information availability plays a vital part in the Q.F.D. process.

06 dealt with a strong positive response to top management commitment affecting the design outcome. Top management commitment was also mentioned in the questionnaire's comments sections as very important to the Q.F.D. process.

Pl7 dealt with a bimodal response to an individual's available Q.F.D. work time affecting the design outcome. After rereading the question, one possible explanation emerged. The question may be answered either positive or negative depending upon the respondent's thought process. The more time individuals had to work on a Q.F.D. project, 
the better the design outcome (a positive questionnaire response). However, when individuals lacked time to work on the Q.F.D. project, the more impaired the design outcome became (a negative questionnaire response). With salaried workforce cutbacks over the past several years some respondents might have commented from the lack-of-time perspective. With increased emphasis on upfront designing/ planning/mistake-proofing some respondents might have commented from the more-planning-time perspective. These perspectives are two different issues, and the ambiguity of the question may have led to the bimodal response. This question should be rewritten for better clarity when this questionnaire is used again.

Using a two-tailed student's $\underline{t}$ test with $95 \%$ criterion, Chart Size (T2), Project Completion Time (012), and Individual's Available Work Time (P17) were observed to be not statistically significant.

T2 dealt with chart size/complexity affecting the design outcome. Chart size simply may not be very important to the Q.F.D. process. This variable was one of the six variables on which ratio data were collected for developing box and whisker $X-Y$ graphs for use in developing guidelines for practitioners. Please see the Ratio Data Assessment section for further discussion.

012 dealt with project completion time affecting the design outcome. From additional questionnaire comments 
and later interviews a possible explanation occurred. New car introduction timing is usually predetermined (by either the standard annual August/September new car rollout or a set corporate strategy). The Q.F.D. projects may have been rushed to make the timeline or may have been completed early with no subsequent earlier introduction of the product. Pl7 dealt with an individual's available Q.F.D. work time affecting the design outcome. The earlier discussion on the ambiguity of this question may also be applicable here.

The response medians show the same general patterns as discussed above. Nine out of the 17 variables had a median of 4.0. The three non-statistically significant variables had medians of 3.0 (no affect). The stronger the probability of significance, the higher the medians were.

\section{Discussion on Cost Findings}

The 17 Cost questions/answers had low relative response numbers and neutral relative means (mean of 3 is no affect). Unusual histograms were defined as having relatively high combinations of standard deviation values (about 1 or higher) and skewness or kurtosis values (about 0.4 or larger). No unusual histograms were identified.

Using a two-tailed student's test with a $95 \%$ criterion, only Team Composition (08), Team Dynamics (010), Project Visibility (013), Personal Commitment (P14), and 
Training (P15) were observed to be statistically significant.

Why did the team leaders respond such that 12 out of the 17 variables were not statistically significant? From additional questionnaire comments and later interviews a possible explanation occurred. With thousands of subcomponents in an automobile it is very difficult to impact the automobile's overall cost. Additionally any cost savings are usually hard to estimate (avoiding manufacturing problems, quality problems, etc.). Thus the Q.F.D. project's impact on the cost outcome may have been very indirect. Contrast this indirectness with the direct impact that the Q.F.D. projects have on Design and Communications outcomes. The Q.F.D. process causes direct decisions to be made on product features. The Q.F.D. process brings a crossfunctional team together face to face and has the different functions explicitly explain and discuss their information and opinions before a team decision is made. These decisions are then written down on the Q.F.D. charts. The Q.F.D. project's indirect impact on the cost outcome may be the cause of the large number of statistically not significant variables.

The response medians show the same general pattern as discussed above. All cost outcome medians were 3.0 (no affect). 
Discussion on Time Findings

The 17 Time questions/answers had the lowest relative response numbers and neutral relative means (mean of 3 is no affect). Unusual histograms were defined as having relatively high combinations of standard deviation values (about 1 or higher) and skewness or kurtosis values (about 0.4 or larger). No unusual histograms were identified.

Using a two-tajled student's test with a $95 \%$ criterion, only Chart Building Methodology (T1), Determining Accurate Weights (T5), Team Composition (08), Project Implementation Level (011), Project Visibility (013), Personal Commitment (P14), Training (P15) and Personal Power (P16) were observed to be statistically significant.

Why did the team leaders respond such that nine out of the 17 variables were not statistically significant? The earlier discussions on annual new car introductions or set corporate strategy predetermining time schedules may be applicable here. The Q.F.D. project's indirect impact on the set time outcome may be the cause of the large number of statistically not significant variables.

The response medians show the same general pattern as discussed above. All time outcome medians were 3.0 (no affect). 
Discussion on Communication

Findings

The 17 Communication questions/answers had high relative response numbers and high relative means (mean above 3 is improved communications). Unusual histograms were defined as having relatively high combinations of standard deviation values (about 1 or higher) and skewness or kurtos is values (about 0.4 or larger). Customer Information Availability (T3) and Individual's Available Work Time (P17) were identified as unusual.

T3 dealt with a very strong positive response to customer information availability affecting the communications outcome. Customer information availability was stated as very important both in the questionnaire responses and additional questionnaire comments and in later interviews. Apparently customer information availability plays a vital part in the Q.F.D. process.

Pl7 dealt with a mixed response to an individual's available Q.F.D. work time affecting the communication outcome. As discussed earlier, the ambiguity of this question may have led to the mixed response. Some respondents may have answered from a lack-of-time perspective, while others may have answered from a more-planning-time perspective. This question should be rewritten for better clarity when this questionnaire is used again. 
Using a two-tailed student's t test with $95 \%$ criterion, Chart Size (T2), Project Completion Time (012) and Individual's Available Work Time (P17) were observed to be not statistically significant.

These three variables are the exact same three variables that were found to be not statistically significant in the Design Findings. The same discussion there applies here.

The response medians show the same general patterns as discussed above. Nine out of the 17 variables had a median of 4.0. The three non-statistically significant variables had medians of 3.0 (no affect). The stronger the probability of significance, the higher the medians were.

\section{Discussion on Integration}

\section{of Findings}

Generally two of the Q.F.D. model's four outcomes appear to be affected strongly by the Q.F.D. variables. These were the Improved Design and Improved Communications outcomes. Generally the Improved Cost and Improved Time outcomes were not affected by the Q.F.D. variables. A possible explanation is that Q.F.D. directly impacts the Improved Design and Improved Communication outcomes by the nature of its process. Q.F.D. in this automotive company may only indirectly impact the Improved Cost outcome and may not impact the predetermined Improved Time outcome. Thus 
Improved Cost and Improved Time outcomes were not affected by the Q.F.D. variables.

Generally three of the 17 Q.F.D. model's variables appear to be not significant to any of the model's four outcomes. Chart Size (T2) simply may not be very important to the Q.F.D. process. Please see the Ratio Data Assessment section for further discussion. Project Completion Time (012) may not be important for the same predetermined time schedule issues discussed earlier. This finding correlates with the Q.F.D. model's Improved Time outcome results. Individuals' Available Work Time (P17) may be an ambiguously worded question. The bimodal mixed responses are an indication that the question should be reworded for better clarity before the questionnaire is used again.

Q.F.D. Outcomes' Descriptive Statistics and Histograms

The four Q.F.D. outcomes were examined as to the degree of improvement when compared to prior non-Q.F.D. experiences. The descriptive statistics are shown in Table VI. The four individual histograms are shown in Appendix F, Questionnaire Q.F.D. Variable/Outcome Histograms.

\section{Design Findings}

The Design question had a high relative response number and a high relative mean (mean of 4 is better than prior experience). The histogram was not unusual. The degree of 
TABLE VI

POTENTIAL Q.F.D. OUTCOMES' DESCRIPTIVE STATISTICS

\begin{tabular}{llllllllll}
\hline & \multicolumn{7}{c}{ Comparison to Prior Non-Q.F.D. Experience } \\
\cline { 3 - 9 } $\begin{array}{l}\text { Out- } \\
\text { come }\end{array}$ & $\begin{array}{c}\text { Outcome } \\
\text { Description }\end{array}$ & $\begin{array}{c}\text { Resp. } \\
\text { No. }\end{array}$ & $\begin{array}{l}\text { Resp. } \\
\text { Mean }\end{array}$ & $\begin{array}{l}\text { Resp. } \\
\text { S.D. }\end{array}$ & $\begin{array}{l}\text { Skew- } \\
\text { ness }\end{array}$ & $\begin{array}{l}\text { Kurt- } \\
\text { osis }\end{array}$ & $\begin{array}{l}\text { Proba- } \\
\text { bility }\end{array}$ & $\begin{array}{l}\text { Resp. } \\
\text { Median }\end{array}$ \\
\hline OUT1 & Impr. Design & 55 & 4.02 & 0.76 & -1.06 & 3.00 & 0.000 & 4.0 \\
OUT2 & Impr. Cost & 53 & 3.34 & 0.73 & 0.27 & -0.10 & 0.001 & 3.0 \\
OUT3 & Impr. Time & 54 & 3.20 & 0.81 & 0.48 & -0.08 & 0.070 & 3.0 \\
OUT4 & Impr. Comm. & 55 & 4.07 & 0.77 & -1.37 & 3.81 & 0.000 & 4.0 \\
\hline
\end{tabular}

NOTE: Probability of obtaining the mean given the hypothesized value of three.

improved design was observed to be statistically significant. The response median showed the same pattern (a 4.0, which is better than prior experience).

\section{Cost Findings}

The Cost question had a low relative response number and a low relative mean (mean of 3 is same as prior experience). The histogram was not unusual. The degree of improved cost was observed to be statistically significant. The response median showed a value of 3.0 (which is same as prior experience).

\section{Time Findings}

The Time question had a low relative response number and a low relative mean (mean of 3 is same as prior 
experience). The histogram was not unusual. The degree of improved time was observed to be not statistically significant. The response median showed the same pattern (a 3.0 , which is same as prior experience).

\section{Communication Findings}

The Communication question had a high relative response number and a high relative mean (mean of 4 is better than prior experience). The histogram was not unusual. The degree of improved communications was observed to be statistically significant. The response median showed the same pattern (a 4.0, which is better than prior experience).

\section{Discussion on Integration}

of Findings

Generally the outcome findings support the variable findings. Q.F.D. strongly impacts/improves the product's design and communication efforts. Q.F.D. may only indirectly impact/improve the product's cost. Q.F.D. may not impact/improve the product's time to market (for this automotive company). The earlier discussions stated in the Q.F.D. Variables' Descriptive Statistics and Histograms section are applicable here as the findings are compatible and reinforcing.

Earlier a theory-based model of Q.F.D. variables was proposed and described. Now these Q.F.D. variables have been statistically described. How do the two descriptions 
compare? Factor analyses were performed on the questionnaire data to help answer that question. These factor analyses are presented next.

Q.F.D. Variables Factor

Analyses

As shown in Figures 8 and 9 , the Q.F.D. variable model consists of 17 variables broken into three discrete groups. The technical group of variables consists of the first five variables (Tl-T5). The organizational group of variables consists of the next eight variables (06-013). The personal group of variables consists of the last four variables (P14P17). Each of these 17 variables could affect each of the four Q.F.D. outcomes. The questionnaire asked how these 17 variables affected each of the four outcomes ( 17 variables times four outcomes equals the first 68 questions).

A separate analysis was done for each of the four outcomes. For each outcome a two-, three- and four-level factor analysis was done to see how these levels compared to the model's three levels. See Table VII for a summary of the results. See Appendix G, Q.F.D. Variables Factor Analyses, for actual computer results.

Models are abstracts of reality, and one potential benefit of models is their simplification of complexity. By adding levels to the factor analysis, an increase in the percent variance explained occurs but at the cost of increasing complexity. Three decision criteria were 
TABLE VII

FACTOR ANALYSES MULTI-LEVEL COMPARISONS

\begin{tabular}{llccc}
\hline $\begin{array}{l}\text { Out- } \\
\text { come }\end{array}$ & $\begin{array}{c}\text { Outcome } \\
\text { Description }\end{array}$ & $\begin{array}{c}\text { Factor Analyses } \\
\text { Level }\end{array}$ & $\begin{array}{c}\text { Percent Variance } \\
\text { Explained }\end{array}$ & $\begin{array}{c}\text { Smallest } \\
\text { Level > 10\% }\end{array}$ \\
\hline OUT1 & Design & 2 & 36 & Yes \\
OUT1 & Design & 3 & 44 & Yes \\
OUT1 & Design & 4 & 49 & No \\
OUT2 & Cost & 2 & 38 & Yes \\
OUT2 & Cost & 3 & 47 & Yes \\
OUT2 & Cost & 4 & 53 & No \\
OUT3 & Time & 2 & 44 & Yes \\
OUT3 & Time & 3 & 51 & Yes \\
OUT3 & Time & 4 & 56 & Yes \\
& & 2 & 43 & Yes \\
OUT4 & Conm. & 2 & 49 & Yes \\
OUT4 & Corm. & 3 & 55 & Yes \\
OUT4 & Cam. & 4 & & \\
\hline
\end{tabular}

selected. First the smallest level had to contribute at least $10 \%$ to the percent variance explained. Second, maximize the percent variance explained. Third, all four outcomes' analyses must be considered. The two-level model was always surpassed by the three-level model in percent variance explained. The three-level model was preferred over a four-level model for Design and Cost outcomes, while the four-level model was marginally preferred for the Time outcome and preferred for the Communications outcome. However, the four-level model did not meet the smallest level >10\% criterion. Since the dissertation's variable model was based on all four Q.F.D. outcomes in general (not on each 
individual Q.F.D. outcome), the three-level model was the appropriate choice.

If the three-level factor analysis corroborates the model's three levels, how do the three-level factor analysis' variables within each of the three levels compare to the model's variable assignments to each level?

The three-level factor analysis which was performed for each of the four outcomes was compared to the model's three levels. See Table VIII for a summary of the results. See Appendix $G$ for the detailed computer results.

Generally Level 1 groupings (the technical groupings) show a strong Customer Information (T3), Competitive Information (T4) pairing and a very weak Determining Accurate Weights (T5) result. Some Technical variables group with Organizational variables, but in this case Technical variables did not group with Personal variables.

Generally Level 2 groupings (the organizational groupings) show a strong Management Commitment (06), Team Composition (08), and Team Size (09) collection, a strong Project Selection (07), Project Visibility (013) pairing and a very weak Project Completion Time (012) result. Some Organizational variables especially Implementation Level (011) group with Technical variables and some Organizational variables group with Personal variables.

Generally Level 3 groupings (the personal groupings) show a strong Training (P15), Personal Power (P16) pairing 
TABLE VIII

MODEL AND FACTOR ANALYSIS THREE-LEVEL COMPARISONS

\begin{tabular}{|c|c|c|c|c|c|}
\hline Level & $\begin{array}{c}\text { Mode1 } \\
\text { Variables }\end{array}$ & $\begin{array}{c}\text { F.A. Design } \\
\text { Variables }\end{array}$ & $\begin{array}{l}\text { F.A. Cost } \\
\text { Variables }\end{array}$ & $\begin{array}{l}\text { F.A. Time } \\
\text { Variables }\end{array}$ & $\begin{array}{l}\text { F.A. Corm. } \\
\text { Variables }\end{array}$ \\
\hline 1 & $\mathrm{Tl}-\mathrm{T} 5$ & $\mathrm{~T} 3, \mathrm{~T} 4$ & $\mathrm{~T} 1, \mathrm{~T} 2,012$ & $\mathrm{~T} 3, \mathrm{~T} 4$ & $\mathrm{~T} 3, \mathrm{~T} 4$ \\
\hline 2 & $06-013$ & $\mathrm{~T} 2,011$ & $\begin{array}{l}\text { T3,T4,06, } \\
08,09\end{array}$ & $\mathrm{~T} 2,011$ & $\begin{array}{l}\mathrm{T} 1, \mathrm{~T} 5,06, \\
07,08,09, \\
010,011 \\
013\end{array}$ \\
\hline 3 & $\mathrm{Pl} 4-17$ & $\begin{array}{l}06,07,08 \\
09,010,013 \\
\mathrm{P} 14\end{array}$ & $\begin{array}{l}07,013, \\
\mathrm{P} 14, \mathrm{P} 15, \\
\mathrm{P} 16\end{array}$ & $\begin{array}{l}08,010 \\
\mathrm{P} 14, \mathrm{P} 15 \\
\mathrm{P} 16, \mathrm{P} 17\end{array}$ & $\mathrm{Pl} 5, \mathrm{Pl} 6$ \\
\hline $\begin{array}{l}\text { Not } \\
\text { Sig- } \\
\text { nif. }\end{array}$ & None & $\begin{array}{l}\mathrm{T} 1, \mathrm{~T} 5,012 \\
\mathrm{P} 15, \mathrm{P} 16, \mathrm{Pl} 7\end{array}$ & $\begin{array}{l}\text { T5,010, } \\
\text { o11, P17 }\end{array}$ & $\begin{array}{l}\mathrm{T} 1, \mathrm{~T} 5,06, \\
07,09, \\
012,013\end{array}$ & $\begin{array}{l}\mathrm{T} 2,012, \\
\mathrm{P} 14, \mathrm{P} 17\end{array}$ \\
\hline
\end{tabular}

NOTES: 1. T1-Chart Bldg. 06-Mgmt. Commit. P14-Pers. Commit. T2-Chart Size 07-Proj. Select. P15-Training T3-Cust. Info. 08-Team Comp. P16-Pers. Power T4-Comp. Info. 09-Team Size P17-Avai1. Time T5-Accur. Wts. 010-Team Dynam.

011-Implem. Level 012-Proj. Comp. Time 013-Proj. Vis.

2. There is no significance associated with level numbering.

3. Computer program uses 0.50 to select significant variables (shown in Appendix G).

and a very weak Individual's Available Work Time (P17) result. Some Personal variables group with Organizational variables, but in this case Personal variables did not group with Technical variables. See Figure 15 for a visual summary of these results. 


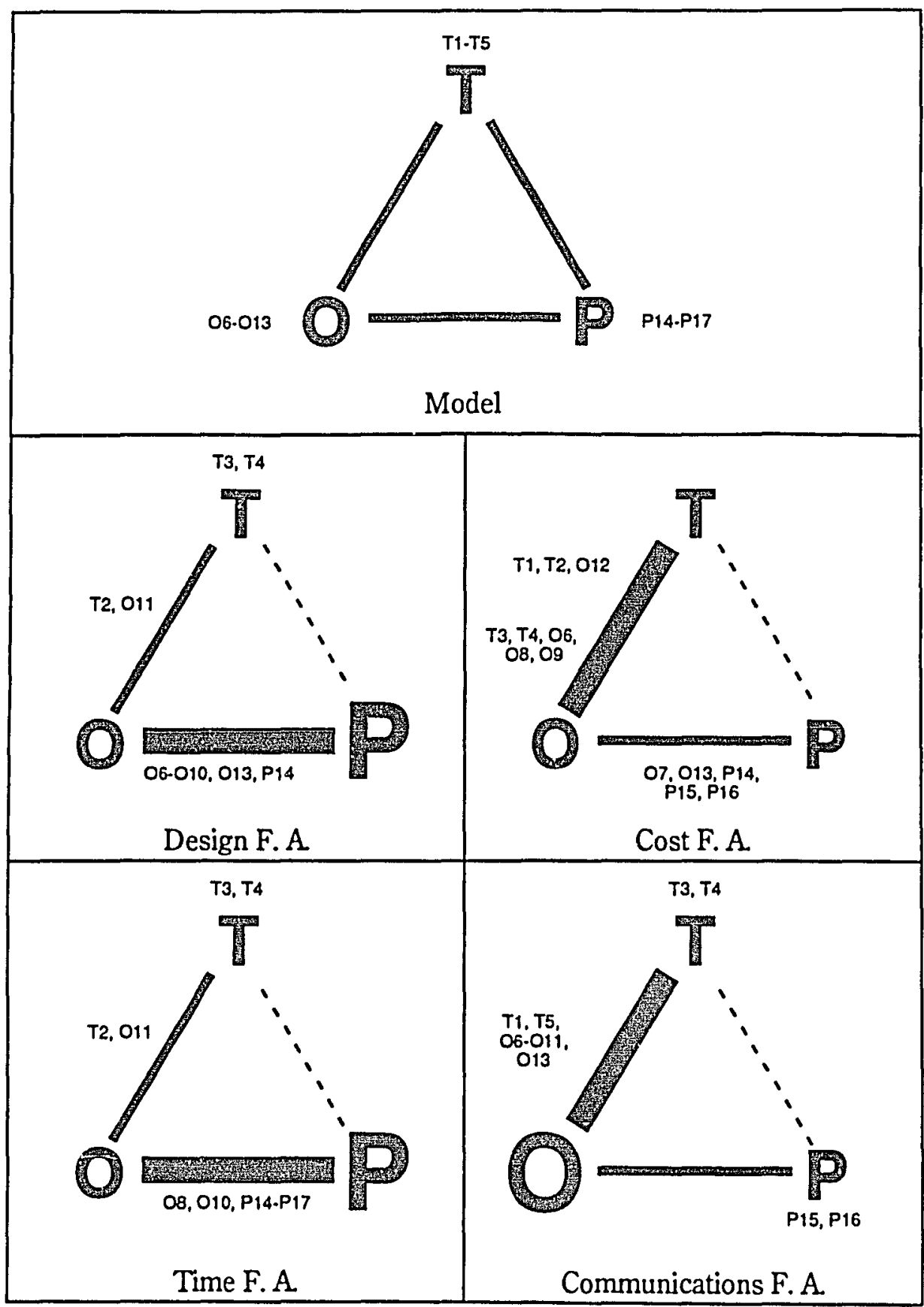

Figure 15. Model and factor analysis three-level visual summaries. (Note: Increasing size of letters and bars indicates increasing strength.) 
A possible explanation for the above results may be that Technical variables are fairly distinct and quantifiable, at least more so than the Organizational variables, which in turn are more distinct and quantifiable than the Personal variables. This leads to the Technical variables being the most consistent grouping and only occasionally grouping with Organizational variables. The Organizational variables are the least consistent grouping as they can and do group with either the Technical or Personal variables. The Personal variables are the second most consistent grouping, and in this case they only grouped with Organizational variables.

Three individual variables--Determining Accurate Weights (T5), Project Completion Time (012) and Individual's Available Work Time (Pl7)--show very weak results. Earlier it was explained that Project Completion Time (012) usually is predetermined by annual new car introduction schedules or corporate strategy, this may account for its weak results. Earlier it was explained that the Individual's Available Work Time (P17) question was ambiguous, this may account for its weak result. Accurate Chart Weights (T5) may just be unimportant, thus its weak result. Deletion of Determining Accurate Weights (T5), Project Completion Time (012) and Individual's Available Work Time (P17) may be warranted. The model's remaining variables and their groupings were appropriate. 
Just how reliable were the questionnaire's data? A reliability assessment is presented next to answer this question.

\section{$\underline{\text { Reliability Assessment }}$}

To assess the reliability of the Q.F.D. variable factors, the internal consistency method was utilized. The three-level factor analysis groupings were utilized for each of the four Q.F.D. outcomes. Pearson's correlation matrix and a frequency table were generated for each grouping. Next Cronbach's coefficient alpha was calculated. See Table IX for summary purposes. See Appendix H, Reliability Matrices and Tables, for detailed computer results.

All factor/outcome scales were deemed acceptably reliable for beginning research when compared to the dissertation's $0.5-0.6$ coefficient alpha acceptable range. In fact nine of the 12 scales exceeded the hoped for 0.7 result, with six above 0.8 and one above 0.9 . The three scales with the lowest reliability coefficient alphas all had only two scale items. This suggests that if more scale items were developed and added that their reliabilities may be improved significantly.

A variation analysis of the data provided some insight into the usefulness of the dissertation's information. The MANOVA analyses are presented next. 
TABLE IX

RELIABILITY ASSESSMENT SUMMARY

\begin{tabular}{llccc}
\hline \multicolumn{1}{c}{ Factor } & $\begin{array}{c}\text { Outcome } \\
\text { Description }\end{array}$ & $\begin{array}{c}\text { No. Scale } \\
\text { Items }\end{array}$ & $\begin{array}{c}\text { Inter-Item } \\
\text { Correlation Ave. }\end{array}$ & $\begin{array}{c}\text { Coefficient } \\
\text { Alpha }\end{array}$ \\
\hline Technical & Impr. Design & 2 & 0.623 & 0.77 \\
Organiz. & Impr. Design & 2 & 0.397 & 0.57 \\
Personal & Impr. Design & 7 & 0.501 & 0.88 \\
Technical & Impr. Cost & 3 & 0.514 & 0.76 \\
Organiz. & Impr. Cost & 5 & 0.467 & 0.81 \\
Personal & Impr. Cost & 5 & 0.420 & 0.78 \\
& & & & 0.89 \\
Technical & Impr. Time & 2 & 0.794 & 0.64 \\
Organiz. & Impr. Time & 2 & 0.520 & 0.87 \\
Personal & Impr. Time & 6 & 0.861 & 0.93 \\
Technical & Impr. Comm. & 2 & 0.428 & 0.87 \\
Organiz. & Impr. Comm. & 9 & & 0.67 \\
Personal & Impr. Comm. & 2 & 0.499 & \\
\hline
\end{tabular}

NOTE: Coefficient Alpha $=\frac{p(r-\text { bar })}{1+(p-1)(r-b a r)}$

where $\mathrm{p} \quad$ number of scale items

where $r$-bar = inter-item correlation ave.

\section{MANOVA Analyses}

Multivariate Analysis of Variance (MANOVA) analyses were conducted to explore significant differences between the Q.F.D. variables for each of the four outcomes, and also between the Q.F.D. outcomes for each of the 17 variables. Via the questionnaire, each outcome was measured 17 times (with each variable), and each variable was measured four times (with each outcome). Thus multiple dependent variables repeated measures MANOVAs were conducted. The testing 
evaluated the differences between the values of the variables and outcomes without any independent variables included in the design. Instead of testing to discover whether the means were equal, the data were transformed so as to discover whether the means were different from each other. See Table X for summary

TABLE X

Q.F.D. VARIABLES' AND OUTCOMES' MANOVA SUMMARY

\begin{tabular}{|c|c|c|c|c|c|}
\hline $\begin{array}{l}\text { Variable/ } \\
\text { Outcome }\end{array}$ & $\begin{array}{l}\text { Variable/Outcome } \\
\text { Interaction }\end{array}$ & $\begin{array}{l}\text { Wilks' } \\
\text { Lambda }\end{array}$ & $\underset{\text { Statistic }}{F}$ & $\begin{array}{l}\text { Degrees of } \\
\text { Freedom }\end{array}$ & $\begin{array}{l}\text { Proba- } \\
\text { bility }\end{array}$ \\
\hline $\begin{array}{l}\mathrm{T} 1 \\
\mathrm{~T} 2 \\
\mathrm{~T} 3 \\
\mathrm{~T} 4 \\
\mathrm{~T} 5\end{array}$ & $\begin{array}{l}\text { Chart Building } \\
\text { Chart Size } \\
\text { Customer Info. } \\
\text { Competitor Info. } \\
\text { Determining Acc. } \\
\text { Weights }\end{array}$ & $\begin{array}{l}0.462 \\
0.907 \\
0.692 \\
0.689 \\
0.921\end{array}$ & $\begin{array}{r}18.639 \\
1.642 \\
6.981 \\
7.086 \\
1.316\end{array}$ & $\begin{array}{l}3,48 \\
3,48 \\
3,47 \\
3,47 \\
3,46\end{array}$ & $\begin{array}{l}0.000 \\
0.192 \\
0.001 \\
0.001 \\
0.281\end{array}$ \\
\hline $\begin{array}{l}06 \\
07 \\
08 \\
09 \\
010 \\
011 \\
012 \\
013\end{array}$ & $\begin{array}{l}\text { Top Mgmt. Commit. } \\
\text { Project Selection } \\
\text { Team Composition } \\
\text { Team Size } \\
\text { Team Dynamics } \\
\text { Implem. Level } \\
\text { Proj. Comp. Time } \\
\text { Proj. Visibility }\end{array}$ & $\begin{array}{l}0.753 \\
0.731 \\
0.597 \\
0.755 \\
0.751 \\
0.874 \\
0.946 \\
0.809\end{array}$ & $\begin{array}{r}5.024 \\
5.151 \\
10.578 \\
5.070 \\
5.200 \\
2.154 \\
0.841 \\
3.609\end{array}$ & $\begin{array}{l}3,46 \\
3,42 \\
3,47 \\
3,47 \\
3,47 \\
3,45 \\
3,44 \\
3,46\end{array}$ & $\begin{array}{l}0.004 \\
0.004 \\
0.000 \\
0.004 \\
0.003 \\
0.107 \\
0.479 \\
0.020\end{array}$ \\
\hline $\begin{array}{l}\text { P14 } \\
\text { P15 } \\
\text { P16 } \\
\text { P17 }\end{array}$ & $\begin{array}{l}\text { Personal Commit. } \\
\text { Train. and Exper. } \\
\text { Personal Power } \\
\text { Individ's. Avail. } \\
\text { Work Time }\end{array}$ & $\begin{array}{l}0.875 \\
0.792 \\
0.874 \\
0.925\end{array}$ & $\begin{array}{l}2.193 \\
4.036 \\
2.160 \\
1.243\end{array}$ & $\begin{array}{l}3,46 \\
3,46 \\
3,45 \\
3,46\end{array}$ & $\begin{array}{l}0.102 \\
0.012 \\
0.106 \\
0.305\end{array}$ \\
\hline $\begin{array}{l}\text { OUT1 } \\
\text { OUT2 } \\
\text { OUT3 } \\
\text { OUT4 }\end{array}$ & $\begin{array}{l}\text { Design } \\
\text { Cost } \\
\text { Time } \\
\text { Communications }\end{array}$ & $\begin{array}{l}0.348 \\
0.530 \\
0.504 \\
0.280\end{array}$ & $\begin{array}{l}4.090 \\
1.995 \\
1.971 \\
6.419\end{array}$ & $\begin{array}{l}16,35 \\
16,36 \\
16,32 \\
16,40\end{array}$ & $\begin{array}{l}0.000 \\
0.043 \\
0.050 \\
0.000\end{array}$ \\
\hline
\end{tabular}


purposes. See Appendix I, MANOVA Analyses, for the detailed computer results.

\section{Discussion}

Using a $95 \%$ criterion, at least one of the following variables' four outcome means was not statistically significantly different from the others: Chart Size (T2), Determining Accurate Weights (T5), Implementation Level (011), Project Completion Time (012), Personal Commitment (P14), Personal Power (P16), and Individuals' Available Work Time (P17). Additionally with variables T2, T5, 011, 012 and P17, all the univariate Probabilities were not statistically significant either. Personal Commitment (P14) and Personal Power (P16) had only one statistically significant univariate Probability.

At least one of the outcomes' 17 variables' means was statistically significantly different from the others.

This result suggested that the means (affectance) of Chart Size (T2), Determining Accurate Weights (T5), Implementation Level (011), Project Completon Time (012) and Individual's Available Work Time (P17), and to a lesser extent Personal Commitment (P14) and Personal Power (P16), do not change very much no matter what the outcome. Chart Size (T2), Determining Accurate Weights (T5), Project Completion Time (012) and Individual's Work Time (P17) were discussed earlier as candidates for dropping from the model 
or rewriting their questions so as to clarify the answers/ information received from their questions. Implementation Level (011), Personal Commitment (P14) and Personal Power (P16) may also be considered as candidates for dropping from the model or rewriting.

Some additional data (ratio data) were collected when the questionnaire was administered. An assessment of these data provided some guidelines for Q.F.D. practitioners. The ratio data assessment is presented next.

\section{Ratio Data Assessment}

Ratio data were collected on six of the 17 Q.F.D. variables. These included Chart Size (T2) (number of chart interrelationships found by multiplying the number of vertical columns and the number of horizontal rows), Customer Information Availability (T3) (percent available), Competitive Information Availability (T4) (percent available), Team Size (09) (number of core team members), Implementation Level (011) (Level/Phase number completed), and Project Completion Time (012) (number of months).

Each of these six values was paired with each of the four Q.F.D. vs. prior experience outcome scores. Each Q.F.D. project's results were collected and displayed in an $X-Y$ box and whisker plot. Due to the outcome scores being whole integers $(1,2,3,4$ or 5), box and whisker median plots were deemed to be more appropriate and meaningful than 
the typical $X-Y$ means graph. The 24 graphs are shown in Appendix J, Ratio Data Graphs.

\section{Discussion on Chart Size (T2)}

Various academics, experts and practitioners have warned about charts becoming so big as to become too complex and unwieldy for the team to utilize. As regards Improved Design, scores of 3 (same as prior experience) had a median chart size of about 650 interactions (about a $25 \times 25$ chart). Better and Much Better Improved Design scores ( 4 and 5) had median chart sizes of about 1,300 to 1,600 interactions (about a $40 \times 40$ chart). Chart sizes larger than that dropped off in Improved Design scores (outliers only appear on 3 and 4 scale). Guideline 1 is: Q.F.D. benefits seem to decline when a Q.F.D. chart contains more than 1,600 interactions. A $1,600+$ size chart might be too complex for the designers to use effectively to improve their designs. As regards Improved Cost, no pattern emerged, perhaps due to the indirect impact Q.F.D. may have on the product's costs as discussed earlier. No additional guidelines could be formulated. As regards Improved Time, no pattern emerged, perhaps due to the predetermined time schedules as discussed earlier. No additional guidelines could be formulated. As regards Improved Communications, the same pattern as Improved Design occurred, except that instead of about a 1,600 interaction threshold, one of about 1,300 interactions 
(a $36 \times 36$ chart) was determined. Guideline 1 may be strengthened and slightly adjusted to become: Q.F.D. benefits seem to decline when a Q.F.D. chart contains more than 1,300 interactions. A $1,300+$ size might be too complex for the designers to use effectively to improve their designs and communication efforts.

Discussion on Customer Information Availability (T3)

The more customer information that is available, the better one would think that the product's design, cost, time-to-market and communication efforts would be. As regards Improved Design, scores of 3 (same as prior experience) had a median of about $30 \%$. Better and Much Better Improved Design scores ( 4 and 5 ) had medians of about $75 \%$ and $50 \%$. This result was not 1 inear. Apparently no Q.F.D. project was attempted or completed with less than about $20 \%$ of the customer information available. Guideline 2 is: Q.F.D. benefits start to occur when there is $20 \%$ or more of the customer information available.

As regards Improved Cost, no pattern emerged, perhaps due to the indirect impact Q.F.D. may have on the product's cost as discussed earlier. No additional guidelines could be formulated. As regards Improved Time, no pattern emerged, perhaps due to the predetermined time schedules as discussed earlier. No additional guidelines could be formulated. As regards Improved Communications, the same pattern 
as Improved Design occurred, except that instead of about a $20 \%$ threshold, one of about 10\% was determined. Guideline 2 , therefore, may remain the same: Q.F.D. benefits start to occur when there is $20 \%$ or more of the customer information available. A smaller amount of information may mean that the designers may not be able to improve their designs and communication efforts because the Q.F.D. project will not be able to be completed.

Discussion on Competitive Information Availability (T4)

The more competitive information that is available, the better one would think that the product's design, cost, time-to-market, and communication efforts would be. As regards Improved Design scores, no patterns or thresholds emerged. No guidelines could be formulated. As regards Improved Cost and Improved Time, no patterns or thresholds emerged, perhaps due to the same possible explanations offered earlier. As regards Improved Communications, generally the more competitive information that was available, the better the communication efforts were. Guideline 3 is: The more competitive information that is available, the better are the Q.F.D. communication benefits.

Discussion on Team Size (09)

Too small a team and not enough diversity and synergy may exist in that team. Too large a team and the diversity 
and unwieldiness hurt the team's effectiveness. An optimum team size may exist. Teams of about five to 12 people were the only ones formed regardless of whether or not their results were better or worse than their prior experience. As regards Improved Design, the better the design outcomes were, the same or larger were the teams. Guideline 4 is: Q.F.D. teams seem to be between five and 12 people in size. As regards Improved Cost, Time and Communications, no patterns emerged. The same guideline of about five to 12 people applies.

Discussion on Implementation Level (011)

The further a Q.F.D. project was completed, one would think the more the product would have had Improved Design, Cost, Time-to-Market and Communications effort. As regards Improved Design, generally the more levels that were completed, the better was the design. Guideline 5 is: The more levels a Q.F.D. team completes, the better the product's design.

As regards the product's Improved Cost, Time-to-Market and Communications efforts, no patterns or thresholds emerged.

Discussion on Project CompleEion Time (012)

The shorter the project completion time, one would think the worse the product's Improved Design, Cost and 
Communications efforts would be. The product's Time-toMarket should be better/improved. As regards Improved Design, Cost, Time and Communications effort, no patterns or thresholds emerged, perhaps due to the same possible predetermined time schedules explanation offered earlier. No guidelines could be formulated.

In addition to the questionnaire's numerical responses, selective interviewing was performed to further assess the Q.F.D. process at the American automotive company. These findings are presented next.

\section{ORGANIZATIONAL ASSESSMENT FINDINGS}

Three Q.F.D. projects were selected for conducting the organizational assessment. The corporate Q.F.D. coordinator confirmed the selection of one outstanding/successful project, one typical project and one difficult/unusual project. Multiple perspective interviewing was used for assessing each of these three Q.F.D. projects. For each Q.F.D. project, at a minimum the team leader, one prominent/ key team member (identified by the team leader) and one impacted but non-team member decision-maker/manager (identified by the team leader) were interviewed. Interviewee and Q.F.D. project confidentiality were promised and sometimes requested before the actual interviewing took place. An ideal Q.F.D. project scenario was modeled and the three Q.F.D. projects' organizational assessments were summarized 
utilizing this same format. This information is presented next.

Ideal Q.F.D. Project

Scenario

Organizations and Relationships. The circles in Figure 15 represent the major organizations involved in a Q.F.D. project. Arrows represent communication and decision flows. Touching circles represent closer organizational bonds than nontouching circles/organizations.

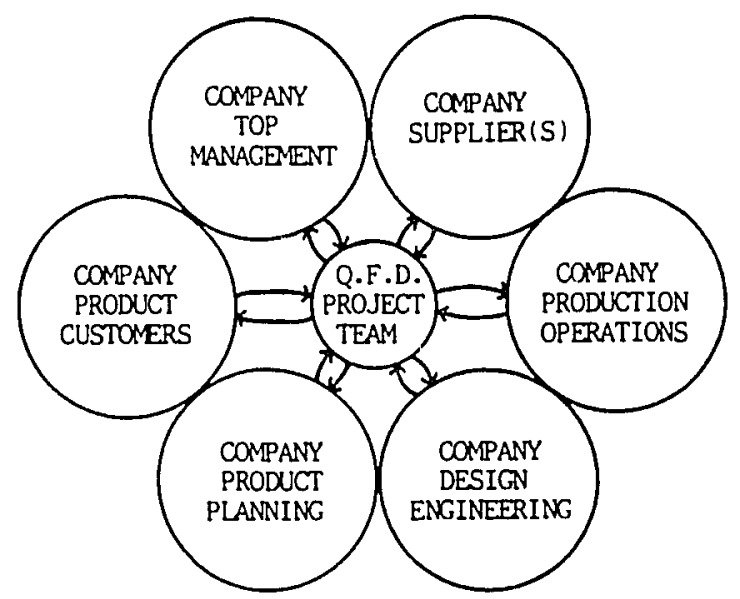

Figure 16: Ideal Q.F.D. project's organizations and relationships.

An ideal Q.F.D. project would be initiated by the Company's Top Management group, and the core team would consist of at least one person from each of the organizations shown in Figure 15. All the core team would have had training in Q.F.D. before starting the project. The team would meet on a periodic basis at the frequency they 
determined was necessary to complete the Q.F.D. project on time. The Q.F.D. project completion time would be set by the core team after considering the relevant company strategies, customer information availability and resources availability. See Table XI for a summary of the ideal project's organizations, goals, and postures and procedures.

Discussion. The ideal scenario consists of the right organizations all fully participating together in conducting the Q.F.D. project. A lack of any one organization's participation may severely limit the success of the Q.F.D. project. The necessary resources must be made available by top management, and the necessary knowledge must be collected and shared with all the organizations involved.

How did the three selected Q.F.D. projects compare to this ideal project scenario? Each of these three Q.F.D. project's findings are presented next.

Outstanding/Successful Q.F.D. Project

Organizations and Relationships. See Figure 16. This Q.F.D. project was initiated by the Company's Supplier Quality group, and the core team consisted of one company person and seven to nine supplier personnel. The team met for two hours a session, with one to two sessions per month for about one year. A project/production deadline was imposed. This was the first exposure to Q.F.D. for the supplier's 
TABLE XI

SUMMARY OF IDEAL Q.F.D. PROJECT'S ORGANIZATIONS, GOALS, AND POSTURES AND PROCEDURES

\begin{tabular}{|c|c|c|}
\hline Organization & Goal & Posture and Procedures \\
\hline $\begin{array}{l}\text { Company Top } \\
\text { Management }\end{array}$ & $\begin{array}{l}\text { To initiate and provide } \\
\text { assistance and resources } \\
\text { to personnel to ensure } \\
\text { best valued products are } \\
\text { produced. }\end{array}$ & $\begin{array}{l}\text { Very favorable toward Q.F.D. } \\
\text { Initiates and fully supports } \\
\text { Q.F.D. projects with train- } \\
\text { ing, funding, and personnel } \\
\text { resources. Checks itself } \\
\text { periodically to ensure } \\
\text { progress in this area. }\end{array}$ \\
\hline $\begin{array}{l}\text { Company } \\
\text { Product } \\
\text { Customers }\end{array}$ & $\begin{array}{l}\text { To purchase the best } \\
\text { valued products. }\end{array}$ & $\begin{array}{l}\text { Very favorable toward Q.F.D. } \\
\text { Volunteers to provide knowl- } \\
\text { edge of customer wants/needs } \\
\text { so best product is produced. }\end{array}$ \\
\hline $\begin{array}{l}\text { Company } \\
\text { Product } \\
\text { Planning }\end{array}$ & $\begin{array}{l}\text { To plan for the best } \\
\text { valued products. }\end{array}$ & $\begin{array}{l}\text { Very favorable toward Q.F.D. } \\
\text { Fully participates on Q.F.D. } \\
\text { project. Leads the customer } \\
\text { information gathering; helps } \\
\text { express it accurately via } \\
\text { Q.F.D. chart/process. }\end{array}$ \\
\hline $\begin{array}{l}\text { Company } \\
\text { Design } \\
\text { Engineering }\end{array}$ & $\begin{array}{l}\text { To design the best } \\
\text { valued products. }\end{array}$ & $\begin{array}{l}\text { Very favorable toward Q.F.D. } \\
\text { Fully participates on Q.F.D. } \\
\text { project. Listens to the } \\
\text { customer, planning and } \\
\text { production inputs via the } \\
\text { Q.F.D. chart/process. }\end{array}$ \\
\hline $\begin{array}{l}\text { Company } \\
\text { Production } \\
\text { Operations }\end{array}$ & $\begin{array}{l}\text { To build the best valued } \\
\text { products. }\end{array}$ & $\begin{array}{l}\text { Very favorable toward Q.F.D. } \\
\text { Fully participates on Q.F.D. } \\
\text { pro ject. Volunteers to pro- } \\
\text { vide mfg. and assembly prob- } \\
\text { lem avoidance knowledge and } \\
\text { helps express it accurately } \\
\text { via Q.F.D. chart/process. }\end{array}$ \\
\hline $\begin{array}{l}\text { Company } \\
\text { Supplier(s) }\end{array}$ & $\begin{array}{l}\text { To provide the best } \\
\text { valued materials and/or } \\
\text { subcomponents for } \\
\text { inclusion in the best } \\
\text { valued products. }\end{array}$ & $\begin{array}{l}\text { Very favorable toward Q.F.D. } \\
\text { Fully participates on Q.F.D. } \\
\text { project. Volunteers to pro- } \\
\text { vide mfg. problem avoidance } \\
\text { knowledge and helps express } \\
\text { it accurately via the Q.F.D. } \\
\text { chart/process. }\end{array}$ \\
\hline
\end{tabular}




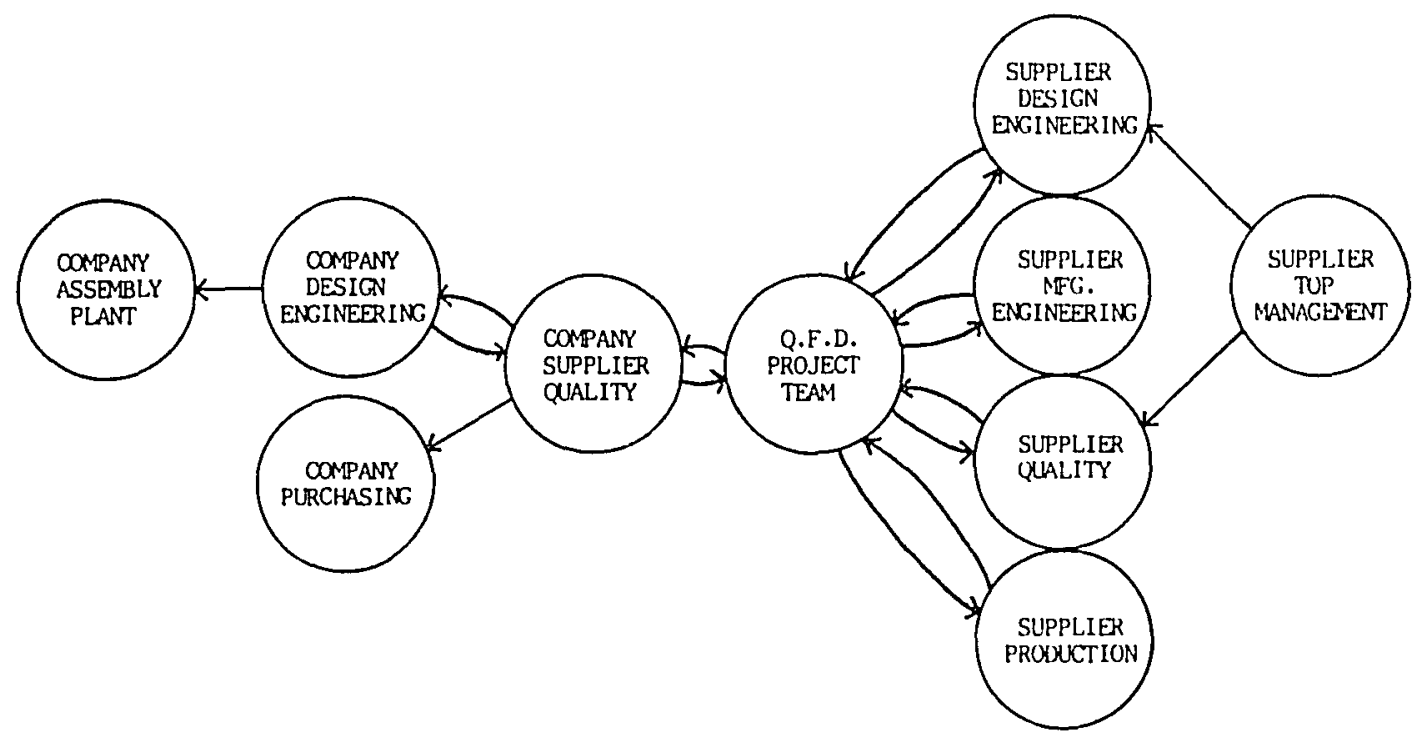

Figure 17. Outstanding/Successful Q.F.D. project's organizations and relationships.

personnel. See Table XII for a summary of the project's organizations, goals, and postures and procedures.

Discussion. The Company's Supplier Quality group viewed the project as very successful since the Q.F.D. project led to some discussions with the Company's Design Engineering group which helped the product's design. Also the Q.F.D. project led to performing a Designed Experiment (DOE) which discovered and solved a major quality problem before full-scale production started.

The supplier's top management remained neutral, having seen some benefits (happy customer, some improved product quality), but also having seen some costs (two people replaced, additional time expended, unmotivated employees). 
TABLE XII

$$
\begin{gathered}
\text { SUMMARY OF OUTSTANDING / SUCCESSFUL Q.F.D. } \\
\text { PROJECT'S ORGANIZATIONS, GOALS, AND } \\
\text { POSTURES AND PROCEDURES }
\end{gathered}
$$

\begin{tabular}{|c|c|c|}
\hline Organization & Goal & Posture and Procedures \\
\hline $\begin{array}{l}\text { Company } \\
\text { Supplier } \\
\text { Quality }\end{array}$ & $\begin{array}{l}\text { To successfully train } \\
\text { Supplier in Q.F.D. on } \\
\text { new modification to } \\
\text { existing product by } \\
\text { specified timeline. }\end{array}$ & $\begin{array}{l}\text { Very favorable toward Q.F.D. } \\
\text { Used standard operating pro- } \\
\text { cedures for coordination } \\
\text { between Supplier groups and } \\
\text { Company Design Engineering. } \\
\text { Coordinated Q.F.D. training } \\
\text { and assistance. }\end{array}$ \\
\hline $\begin{array}{l}\text { Supplier } \\
\text { Top } \\
\text { Management }\end{array}$ & $\begin{array}{l}\text { To please the Company } \\
\text { which is a major pur- } \\
\text { chaser of their } \\
\text { products. }\end{array}$ & $\begin{array}{l}\text { Neutral wait-and-see atti- } \\
\text { tude toward Q.F.D. Used } \\
\text { hands-off, let-team-do-work } \\
\text { management procedures. } \\
\text { However, eventually removed } \\
\text { Design Engineer and Quality } \\
\text { Manager for non-team play. }\end{array}$ \\
\hline $\begin{array}{l}\text { Supplier } \\
\text { Q.F.D. Tean } \\
\text { Members }\end{array}$ & $\begin{array}{l}\text { Complete Q.F.D. project } \\
\text { to please Supplier Top } \\
\text { Management and Company } \\
\text { Supplier Quality. }\end{array}$ & $\begin{array}{l}\text { Unfavorable toward Q.F.D. } \\
\text { Viewed as company program } \\
\text { of the year, having had } \\
\text { DOE, FMEA and SPC past } \\
\text { experiences. Found the } \\
\text { Q.F.D. training confusing } \\
\text { and saw a lack of top } \\
\text { management presence. Most } \\
\text { used teamwork; two over- } \\
\text { dominated and were removed } \\
\text { eventually. }\end{array}$ \\
\hline
\end{tabular}

The Supplier's Q.F.D. team members remained unfavorable to Q.F.D., claiming it did not teach them anything new. They were of the opinion that if the Company's Design Engineering group would work more closely with them they would be able to improve their product quality anyway. They admitted that one of the two people removed needed to be removed 
anyway and were neutral on the other personnel change. They definitely did not view the Q.F.D. project as a success.

Typical Q.F.D. Project

Organizations and Relationships. See Figure 17. This Q.F.D. project was initiated by the Company's Advance Team Design Engineering group, and the core team consisted of one person from each organization plus the team leader from the Company's Advance Team Design Engineering group. The team was actually still in what they termed as the pre-Phase 1 stage. They had not been through Q.F.D. training together, but all had had some form or exposure to Q.F.D. in their past experiences. All were professional degreed individuals. The team leader contacted members by phone or circulated documents for input or information. Contact occurred about once every two weeks. This format had been used for about six months. The team leader had plans to transition

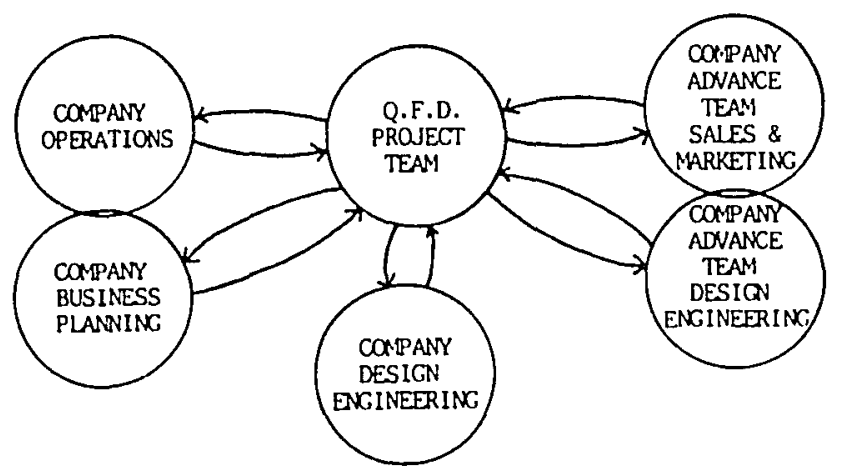

Figure 18. Typical Q.F.D. project's organizations and relationships. 
to face-to-face meetings on an as needed basis. Several team members had known each other through past work assignments. No specific timeline had been established. See Table XIII for a summary of the project's organizations, goals, and postures and procedures.

Discussion. The Company's Advance Team groups (both Sales and Marketing and Design Engineering) viewed Q.F.D. favorably and were clearly focused on the success of this new major subcomponent system. The success of the Advance Team as a whole was directly tied to a successful design and

TABLE XIII

SUMMARY OF TYPICAL Q.F.D. PROJECT'S ORGANIZATIONS, GOALS, AND POSTURES AND PROCEDURES

\begin{tabular}{|c|c|c|}
\hline Organization & Goal & Posture and Procedures \\
\hline $\begin{array}{l}\text { Company } \\
\text { Advance Team } \\
\text { Design } \\
\text { Engineering }\end{array}$ & $\begin{array}{l}\text { To successfully design } \\
\text { new major subcomponent } \\
\text { system for internal and } \\
\text { external sales. }\end{array}$ & $\begin{array}{l}\text { Very favorable toward Q.F.D. } \\
\text { Used unusual standard oper- } \\
\text { ating procedures for coordi- } \\
\text { nation between team members. } \\
\text { Have not had full team } \\
\text { meeting to date. Verbal } \\
\text { and written one-to-one } \\
\text { exchanges. No coordinated } \\
\text { training was conducted. }\end{array}$ \\
\hline $\begin{array}{l}\text { Company } \\
\text { Advance Team } \\
\text { Sales and } \\
\text { Marketing }\end{array}$ & $\begin{array}{l}\text { To obtain and use market } \\
\text { information in the } \\
\text { design of the new major } \\
\text { subcomponent system. }\end{array}$ & $\begin{array}{l}\text { Favorable toward Q.F.D. } \\
\text { Assertive team play proce- } \\
\text { dures utilized. }\end{array}$ \\
\hline $\begin{array}{l}\text { Company } \\
\text { Operations }\end{array}$ & $\begin{array}{l}\text { To receive a produceable } \\
\text { assemblable good subcom- } \\
\text { ponent system. }\end{array}$ & $\begin{array}{l}\text { Neutral toward Q.F.D. Lack } \\
\text { of time, wait-and-see-what- } \\
\text { unfolds approach. }\end{array}$ \\
\hline
\end{tabular}


launch of this product. It was their whole reason for being in existence.

The company's other groups (Operations, Business Planning and Design Engineering) viewed Q.F.D. neutrally or slightly favorably. The subcomponent system, while important, was only a subcomponent of the entire automobile. Their success was not tied either way to the success or failure of the new product. They could and presently did buy this subcomponent system equivalent from suppliers. Their focus was on current production and its problems and increasing their productivity. Little time had been allotted for future new product development efforts.

\section{Difficult/Unusual Q.F.D.}

\section{$\underline{\text { Project }}$}

Organizations and Relationships. See Figure 18. This Q.F.D. project was initiated by the Company's Design Engineering group, and the core team consisted of four of their personnel including the team leader and two from the

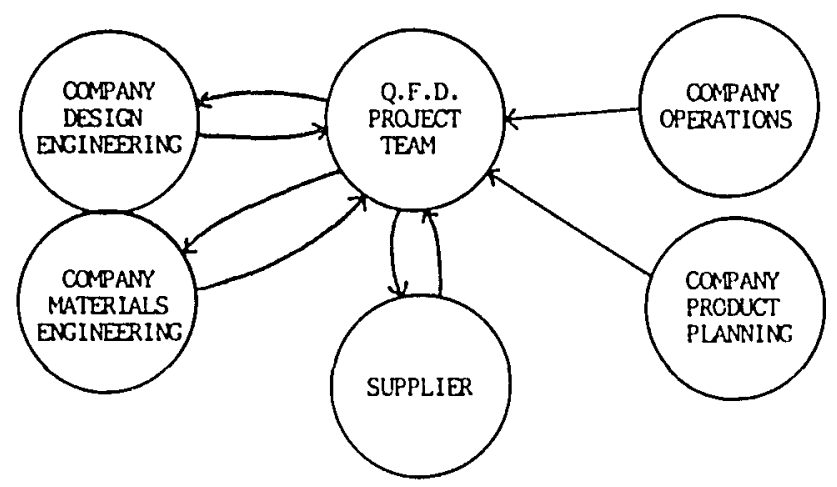

Figure 19: Difficult/Unusual Q.F.D. project's organizations and relationships. 
Company's Materials Engineering group and one person each from the remaining groups. The core team did not train in Q.F.D. together, but all had some training before starting the project. The team met about two hours every two weeks for about eight months. A deadline was imposed by management. See Table XIV for a summary of the project's organizations, goals, and postures and procedures.

Discussion. The Company's Design Engineering group had decided to do a Q.F.D. project as this technique was heralded as being very helpful. A product was selected and the Company's Materials Engineering group and the Supplier were asked to participate. Q.F.D. calls for a crossfunctional team, so the Company's Operations and Product Planning groups were asked to help too. They had reluctant 1 y agreed.

The Company's Design Engineering management had changed one month after the project started. There was no real champion; this Q.F.D. project was piled on top of other work projects, and no money was allocated to it. Company Operations saw little benefit to them in the short term. They felt they had no warranty or repair information and so could not contribute anything. So to them it was a waste of their time. Company Product Planning saw it as an infringement on their marketing research area, not a priority for their department and no nondepartment funds were available to 
TABLE XIV

SUMMARY OF DIFFICULT/UNUSUAL Q.F.D. PROJECT'S

ORGANIZATIONS, GOALS, AND POSTURES

AND PROCEDURES

\begin{tabular}{|c|c|c|}
\hline Organization & Goal & Posture and Procedures \\
\hline $\begin{array}{l}\text { Company } \\
\text { Design } \\
\text { Engineering }\end{array}$ & $\begin{array}{l}\text { To accomplish a Q.F.D. } \\
\text { project. }\end{array}$ & $\begin{array}{l}\text { Slightly favorable toward } \\
\text { Q.F.D. Standard operating } \\
\text { procedure was used to have } \\
\text { goal tied to performance } \\
\text { review at low priority } \\
\text { level. Manager changed } \\
\text { after one month. }\end{array}$ \\
\hline $\begin{array}{l}\text { Company } \\
\text { Materials } \\
\text { Engineering }\end{array}$ & $\begin{array}{l}\text { To participate as } \\
\text { requested by fellow } \\
\text { engineers. }\end{array}$ & $\begin{array}{l}\text { Neutral toward Q.F.D. Busi- } \\
\text { ness and professional ties } \\
\text { to Design Engineering gener- } \\
\text { ated some response to } \\
\text { participate. }\end{array}$ \\
\hline Supplier & To appease customer. & $\begin{array}{l}\text { Negative toward Q.F.D. } \\
\text { Another program of the } \\
\text { month. Standard operating } \\
\text { procedure is to do whatever } \\
\text { the customer wants while } \\
\text { minimizing the pain } \\
\text { involved. }\end{array}$ \\
\hline $\begin{array}{l}\text { Company } \\
\text { Operations }\end{array}$ & Minimize time involved. & $\begin{array}{l}\text { Negative toward Q.F.D. Used } \\
\text { physical and business } \\
\text { distance to sporadically } \\
\text { attend. }\end{array}$ \\
\hline $\begin{array}{l}\text { Company } \\
\text { Product } \\
\text { Planning }\end{array}$ & $\begin{array}{l}\text { Minimize time and money } \\
\text { involved. }\end{array}$ & $\begin{array}{l}\text { Negative toward Q.F.D. Saw } \\
\text { it as engineering tool to } \\
\text { get in marketing area. Used } \\
\text { organizational priorities } \\
\text { and high expense estimates } \\
\text { to stop marketing research } \\
\text { inquiries. }\end{array}$ \\
\hline
\end{tabular}


conduct any market research so they essentially stopped participating.

Personalities also may play a major role in the Q.F.D. process. A personal assessment was conducted on the same three Q.F.D. projects described above. These findings are presented next.

\section{PERSONAL ASSESSMENT FINDINGS}

The same three Q.F.D. projects selected for the organizational assessment were used in conducting the personal assessment. Multiple perspective interviewing was used for assessing each of these three Q.F.D. projects. For each Q.F.D. project, at a minimum the team leader or contact, one prominent/key team member (identified by the team leader) and one impacted but non-team member decision-maker/manager (identified by the team leader) were interviewed. Interviewee and Q.F.D. project confidentiality was promised and sometimes requested before the actual interviewing took place. Brief descriptions of the key individuals of the three Q.F.D. projects are presented next.

Outstanding/Successful Q.F.D. Project: Key Individuals Descriptions

The Optimist (Team Contact). The nice guy with the eternally positive attitude. Everything is improved or is improving. He possesses a firm belief in Q.F.D. and that 
people generally want to do a good job. He perceives his job as a coordinator who gets people together so they can solve problems to their mutual benefit.

The Doubting Thomas (Team Member). The employee who questions the benefit of any activity. He is confused about the purpose of Q.F.D.; he questions the amount of time spent on the project, the benefits gained from the project, the lack of resources allocated to the project, etc.

The Theory $Y$ Leader (Non-Team Member Manager). The leader who believes in giving subordinates a wide range of authority and responsibility. Teamwork is the only way to improve productivity. Eventually continual non-team play will not be tolerated.

Discussion. The Optimist appeared to be unaware or subconsciously minimizing some of the Q.F.D. project's problems. His dogged, purposeful, positive approach kept the project progressing. He simply would not let it die when it reached a crisis point.

The Doubting Thomas questioned everything, even contradicting himself. Not only "What was the Q.F.D. project's purpose?" and "Why do it?" but also "Why were not more resources allocated to do it?" This team member was negative to neutral, but he would do what he was told to do (participate in Q.F.D. project).

The Theory Y leader entrusted the Q.F.D. project responsibility to his people. He did not want to dominate 
or influence their actions. They viewed his lack of appearance as a lack of leadership and priority. Two of the more dominating people asserted themselves and brought the Q.F.D. project to a standstill. Concern for his customer and his other team players led Theory $Y$ to terminate one person and cause the resignation of the other person by mutual agreement. The Q.F.D. project's progress, which had reached a standstill, resumed forward momentum.

Typical Q.F.D. Project: Key Individuals Descriptions

The Young Buck (Team Leader). This individual possessed the desire, energy and skills to cause action. Selected by top management to be the key to a major new product development effort, this person had a mission. Embodying enthusiasm, exuding confidence, his charisma was immediately noticeable.

The Proponent (Team Member). This person was a polite, positive, proactive professional. Confident in the team's eventual success and confident in the team member's ability to contribute to that team success. Rationally ticked off Q.F.D. milestones and the potential problems which might arise before the team had succeeded (not if it succeeded). The Nonpartisan (Non-team Member Manager). The guy who has been around the block a few times. He will wait and see what happens. This Q.F.D. stuff is probably more important for the younger guys. Every department is an empire unto 
itself, and if the project helps, it's okay; if it does not help, their department had not wasted resources.

Discussion. The Young Buck was selected by top management and clearly had past relevant experience and skills. His dynamic, energetic personality was an attractive magnet to people like the Proponent who wanted to be associated with progress and success. He had used some unusual methods to minimize the time involved at getting the Q.F.D. project started, thus keeping the Nonpartisan's group involved. With a minimal amount of cost (their time) and a perceived large benefit (new big project success), the team members had strong commitments to the Q.F.D. project.

Difficult/Unusual Q.F.D. Project: Key Individuals' Descriptions

The Fatalist (Team Leader). This person was resigned to the fact that most things do not work out as planned. He had not perceive himself as the Q.F.D. project champion, while others had looked to him to be that champion. His personal view of lack of management support and commitment in terms of people, people's time, project time and money had permeated the other team members.

The Plodder (Team Member). This individual worked steadily at the tasks sent down to his out-of-the-way desk. Once found, he quietly and laboriously described in detail his recollections of the project. Once started down this 
path, it was hard to get him to deviate from it. Questions in other directions and exiting excuses went unnoticed. He still may be muttering on.

The Rising Star (Non-team Member Manager). The rapid promotions of this individual were apparent; the telephone directory 1 isted one location. After having arrived at that location, the secretary referred to him as having been "bumped upstairs." At this "upstairs" office the secretary referred the interviewer on to his very latest position/ office. Finally at that office, which was still being arranged, he was present. A self-described big picture problem-solver, he was not arrogant but rather very direct and very busy.

Discussion. With the Fatalist not championing the Q.F.D. project and no one soliciting the top management support for people and money, the Q.F.D. project was handicapped from the very beginning. With the Rising Star having moved on one month after the project was started, there was no one to carry the torch and the diverse organizations involved reverted back to plodding along toward their own objectives.

An integration of the Technical, Organizational and Personal Assessment Findings is presented next. 


\section{INTEGRATION OF ASSESSMENTS}

The assessments' findings were examined to see if they complemented or worked at cross purposes with each other. There is a large risk in extrapolating the three Q.F.D. projects' organizational and personal assessments to the approximately 100 Q.F.D. projects. There is also a large risk in integrating the three assessments due to their selection criteria (Outstanding/Successful, Typical, Difficult/Unusual). Therefore, only lists of the similarities and discontinuities between the assessments are presented.

\section{Q.F.D. Variables' Assess-} ments Similarities

The three perspectives--technical, organizational and personal--all pointed toward commitment to the Q.F.D. project as important. Whether it was top management, organizational or a personal commitment, commitment seemed necessary to move the Q.F.D. project along when it hit the real-world difficult moments.

Customer information availability also was a consistent theme throughout all three assessments. The lack of customer information seemed to severely hamper the Q.F.D. project effort.

The team's composition and dynamics certainly impacted the Q.F.D. project. The technical assessment showed this, 
but it was especially confirmed in the organizational and personal assessments.

Finally, the Q.F.D. project completion time was an important variable too. Unfortunately the technical assessment question was ambiguously worded. However, during the organizational and personal assessments many strongly stated positions were received that a strictly imposed project completion time was generally detrimental to the Q.F.D. project (it rushed the project and sacrificed the quality of the Q.F.D. process).

Q.F.D. Outcomes' Assessments Similarities

The technical assessment clearly showed that the strongest outcomes were improved product design and improved communications and documentation efforts. This was confirmed during the organizational and personal assessments. The Q.F.D. project's time-to-market was not affected as this was predetermined by annual new model introduction schedules or by corporate strategy. The Q.F.D. project's product cost seems to be so indirectly related to the Q.F.D. project as to not show a strong tie to the Q.F.D. project efforts. Thus by comparison the Design and Communication outcomes were stronger than the Time and Cost outcomes for this American automotive company. 
Q.F.D. Variables' Assess-

ments Discontinuities

There were no major discontinuities between the three assessments concerning the variables which may affect a Q.F.D. project.

Q.F.D. Outcomes' Assessments Discontinuities

There were no major discontinuities between the three assessments concerning the Q.F.D. outcomes.

\section{SUMMARY}

After reviewing the model, the technical assessment findings were reported. An $80 \%$ questionnaire response was obtained with no nonrespondent bias found. Descriptive statistics and histograms were developed and described for both Q.F.D. variables and outcomes responses (see Table VI). Generally the Improved Design and Improved Communications outcomes had stronger positive responses than Improved Cost and Improved Time outcomes. A possible explanation was offered. The Improved Time outcome was predetermined, and the Improved Cost outcome was only indirectly related to the Q.F.D. project.

Customer Information Availability and Top Management Commitment had non-normal and large variations in their responses. This was due to a large amount of strong 
affecting responses. One ambiguous question was discovered concerning Individual's Available Work Time.

Factor analyses were performed on the Q.F.D. variables model. Overall a three-level analysis appeared to be the best selection from among the two-, three- and four-level analyses that were run for each of the four outcomes. This three-level result agreed with the model's proposed three levels (see Table VII).

A comparison of the three-level factor analysis and the three-level model showed that most variables were explaining a significant amount of variation in the four different outcomes. In this study Technical variables did not group with Personal variables, while Organizational variables did group with both Technical and Personal variable groups. Three variables--Determining Accurate Weights (T5), Projection Completion Time (012) and Individual's Available Work Time (P17)--may be considered for deletion from the model for this study (see Table VIII).

A Reliability Assessment was conducted and all factor/ outcome scales were found to be within or have exceeded the acceptable beginning research coefficient alpha range of 0.5-0.6 (see Table IX).

Multiple dependent variables repeated measures MANOVAs were conducted. The testing evaluated the differences between the values of the variables and outcomes without any independent variables included in the design. The data were 
transformed so as to test whether the means were different from each other. Five variables' means do not change very much no matter what the outcome. These variables may be considered for deletion from the model--Chart Size (T2), Determining Accurate Weights (T5), Implementation Level (011), Project Completion Time (012) and Individual's Available Work Time (P17). To a lesser extent two other variables may also be considered for deletion--Personal Commitment (P14) and Personal Power (P16) (see Table X).

A Ratio Data Assessment was conducted using six of the 17 variables on which additional data had been collected via the questionnaire. These six variables were Chart Size (T2), Customer Information Availability (T3), Competitive Information Availability (T4), Team Size (09), Implementation Level (011), and Project Completion Time (012). These six variables' ratio data were paired with each project's four outcomes' improvement to prior experience scores. This information was plotted on box and whiskers $X-Y$ graphs. Five guidelines were developed from this information (see Appendix $J$ for the 24 graphs).

After the technical assessment findings were reported, the organizational assessment findings were reported. An ideal Q.F.D. project scenario was modeled. Utilizing the same format three Q.F.D. projects--Outstanding/Successful, Typical, and Difficult/Unusual--were examined. The major organizations, relationships, goals and postures and 
procedures were described and discussed for each of these projects.

After the technical and organizational findings were reported, the personal assessment findings were reported. The same three projects and interviewees were utilized as in the organizational assessment. Each of the three Q.F.D. project's key individuals' personal descriptions were compiled and discussed.

An integration of the three assessments was compiled. This consisted of 1 isting the Q.F.D. Variables' and Outcomes' assessments' similarities and discontinuities.

Chapter V, Conclusions, Contributions, Future Research Recommendations and Summary of the Research, is presented next. The dissertation's references and supporting appendices are presented last. 


\author{
CHAPTER V \\ CONCLUSIONS, CONTRIBUTIONS, FUTURE RESEARCH \\ RECOMMENDATIONS AND SUMMARY \\ OF THE RESEARCH
}

INTRODUCTION

\begin{abstract}
The Conclusions and Contributions of the research are stated and presented. Future Research Recommendations are made and presented. A Summary of the research problem, the literature review, the research model, the design of the research, the findings of the research, the conclusions of the research, the contributions of the research and the future research recommendations are also presented. The chapter is summarized and the balance of the dissertation is then presented.
\end{abstract}

CONCLUSIONS OF THE RESEARCH

1. There is a limited amount of English language literature on Q.F.D. The majority of what does exist is very general in nature.

2. There presently does not exist any descriptive or prescriptive Q.F.D. models. 
3. There presently does not exist any standard Q.F.D. research measuring instrument.

4. An American automotive company's internal Q.F.D. projects have been studied and used to verify a general purpose Q.F.D. implementation model's variables' and outcomes' relationships. For this company Chart Size (T2), Determining Accurate Weights (T5), Implementation Level (011), Project Completion Time (012), and Individual's Available Work Time (P17) variables may be candidates for removal from the model or rewritten for clarification purposes. For this company Improved Design and Improved Communication outcomes were significantly better than the prior product development methodology. No significant change was found with the Improved Cost or Improved Time-to-Market outcomes.

5. For this American automotive company five guidelines were developed. First, Q.F.D. benefits seem to decline when a Q.F.D. chart contains more than 1,300 interactions. Second, Q.F.D. benefits start to occur when there is $20 \%$ or more of the customer information available. Third, the more the competitive information that is available, the better are the Q.F.D. communication benefits. Fourth, Q.F.D. teams seem to be between five and 12 people in 
size. Fifth, the more levels a Q.F.D. team completes, the better the product's design.

6. For this American automotive company similarities between the technical, organizational and personal assessments regarding Q.F.D. variables included commitment (top management, organizational and personal), customer information availability, team composition and dynamics and project completion time.

7. For this American automotive company similarities between the technical, organizational and personal assessments regarding Q.F.D. outcomes included Improved Design and Improved Communications as the major results from utilizing Q.F.D. Improved Cost was only indirectly affected and Improved Time-toMarket was not affected.

8. For this American automotive company no major discontinuities between the technical, organizational and personal assessments regarding either Q.F.D. variables or outcomes were found.

CONTRIBUTIONS OF THE RESEARCH

1. An English language literature list of articles and books on Q.F.D. has been compiled. 
2. A general purpose Q.F.D. implementation model has been created which describes both Q.F.D. variables and outcomes.

3. A general purpose standard Q.F.D. research measuring instrument has been created.

4. An American automotive company's Q.F.D. projects have been researched for verifying both the general purpose Q.F.D. model and the Q.F.D. research measuring instrument.

5. Another Multiple Perspectives study has been completed which adds to the growing body of knowledge on the effectiveness of going beyond the standard technical assessment process.

\section{FUTURE RESEARCH RECOMMENDATIONS}

1. Additional academic research should be conducted on the Q.F.D. implementation process to further aid practitioners in developing Successful Q.F.D. projects. Specifically additional research on the Q.F.D. implementation model's variables and outcomes would be especially beneficial. Also research to further refine and expand practitioners guidelines would be beneficial. Some research by Andreas Krinninger, Amit Pandey and Professor Don Clausing with the Laboratory for Manufacturing and Productivity at the Massachusetts Institute of 
Technology is currently underway to this end. Additionally Assistant Professor M. Christine Lewis and Associate Professor Barbara Price of School of Business at Wayne State University are currently studying the Q.F.D. process.

2. Additional research should be conducted by nonAmerican industries/companies on the Q.F.D. implementation process. This research would provide interesting cultural analysis opportunities.

3. Additional industry/company studies should be conducted utilizing the general purpose Q.F.D. model and measuring instrument. This research would enable further validation and refinement of the model and instrument. These studies would also present an interesting comparison between industries and companies. Some companies who are known to have an extensive number of Q.F.D. projects are $\mathrm{AT}$ and $\mathrm{T}, \mathrm{Black}$ and Decker, Chrysler, DEC, General Electric, General Motors, Hewlett-Packard, Honda, Oregon Cutting Systems, and Proctor and Gamble, and Toyota.

4. Additional research should be conducted on the Q.F.D. implementation process on the company studied in this dissertation. This research would provide interesting time trend analysis opportunities. 
5. Additional research should be conducted to develop expert or knowledge based Q.F.D. systems. Some work has already begun in this area (31).

\section{SUMMARY OF THE RESEARCH}

This dissertation's research objective was to provide information about Q.F.D. The dissertation's four research questions were:

1. What are the variables which affect Q.F.D.?

2. What are the outcomes from using Q.F.D.?

3. What relationships exist between Q.F.D. variables and outcomes?

4. What guidelines may be offered to practitioners of Q.F.D.?

The boundaries on the dissertation were explicitly set as to include only the subset of the Total quality Function Deployment System known as Quality Function Deployment. Only an American automotive company's Q.F.D. effort was studied and the external environment was specifically excluded. This dissertation did provide significant information about Q.F.D. which will help the American automotive industry overcome a nine to 12 year Q.F.D. experience curve lag. This may lead to more successful competition in the international arena for billions of dollars of sales and wealth and the location of millions of jobs. 
Q.F.D. new product development and socio-technical analysis literature searches and reviews were conducted and presented. Recognizing a lack of a Q.F.D. implementation model, the Multiple Perspectives methodology was utilized to construct a Q.F.D. implementation model framework. Using literature sources and academic, expert and practitioner inputs, specific model elements were developed and described. By inserting the model elements into the implementation model's framework, an initial descriptive Q.F.D. implementation model was completed, as was the compilation of the known English language Q.F.D. material. See Figures 8 and 9 and References section of this dissertation.

The dissertation's research objective and questions were developed into 99 specific research hypotheses. The dissertation's research design methodology was based on a Multiple Perspectives approach. This approach used three assessment processes--technical, organizational and personal.

The technical assessment utilized the research hypotheses and developed a measurement instrument (questionnaire). This questionnaire was administered to approximately all Q.F.D. project team leaders via the Total Design Method. This multi-step method has been demonstrated to obtain very high response rates. Descriptive statistics, histograms, factor analyses and reliability coefficients were calculated/constructed to examine the first 72 research 
hypotheses. MANOVA analyses were conducted to examine the next 21 research hypotheses. Further, graphical relationships for 24 selected variable/outcome relationships were constructed to provide guidelines for Q.F.D. practitioners (to examine the last six research hypotheses).

The organizational assessment utilized one interviewer to conduct face-to-face interviews with key company personnel to obtain qualitative brief summaries of various organizations' postures and positions supporting or opposing the Q.F.D. project. Three Q.F.D. projects (one successful, one typical, and one difficult) were assessed and compared to an ideal Q.F.D. project scenario.

The personal assessment utilized a similar measurement methodology and data collection process and the same three Q.F.D. projects as the organizational assessment. Brief personal descriptions were constructed to capture the essence of key individuals' intuitions, leadership qualities, and self-interests.

The technical, organizational, and personal assessments were examined for similarities and discontinuities. The major similarities and discontinuities were then 1 isted.

The dissertation's research findings were reported. An $80 \%$ questionnaire response was obtained with no respondent bias found. Descriptive statistics and histograms were developed and described for both Q.F.D. variables' and outcomes' responses. See Table VI. Generally the Improved 
Design and Improved Communications outcomes had stronger positive responses than the Improved Cost and Improved Time outcomes. A possible explanation was offered. The Improved Time outcome was predetermined, and the Improved Cost outcome was only indirectly related to the Q.F.D. project.

Customer Information Availability and Top Management Commitment had non-normal and large variations in their responses. This was due to a large amount of strong affecting responses. One ambiguous question was discovered concerning Individual's Available Work Time.

Factor analyses were performed on the Q.F.D. variables model. Overall a three-level analysis appeared to be the best selection from among the two-, three- and four-level analyses that were run for each of the four outcomes. This three-level result agreed with the model's proposed three levels. See Table VII.

A comparison of the three-level factor analysis and the three-level model showed that most variables were explaining a significant amount of variation in the four different outcomes. In this study Technical variables did not group with Personal variables, while Organizational variables did group with both Technical and Personal variable groups. Three variables--Determining Accurate Weights, Project Completion Time and Individual's Available Work Time may be considered for deletion from the model for this study. See Table VIII. 
A Reliability Assessment was conducted and all factor/ outcome scales were found to be within or have exceeded the acceptable beginning research coefficient alpha range of 0.5-0.6. See Table IX.

Multiple dependent variables repeated measures MANOVAs were conducted. The testing evaluated the differences between the values of the variables and outcomes without any independent variables included in the design. The data were transformed so as to test whether the means were different from each other. Five variables' means do not change very much no matter what the outcome. These variables may be considered for deletion from the mode1--Chart Size, Determining Accurate Weights, Implementation Level, Project Completion Time and Individual's Available Work Time. To a lesser extent two other variables may also be considered for deletion--Personal Commitment and Personal Power. See Table X.

A Ratio Data Assessment was conducted using six of the 17 variables on which additional data had been collected via the questionnaire. These six variables were Chart Size, Customer Information Availability, Competitive Information Availability, Team Size, Implementation Level, and Project Completion Time. These six variables' ratio data were paired with each project's four outcomes' improvement to prior experience scores. This information was plotted on 
box and whiskers $X-Y$ graphs. Five guidelines were developed from this information. See Appendix $J$ for the 24 graphs. After the technical assessment findings were reported, the organizational assessment findings were reported. An ideal Q.F.D. project scenario was modeled. Utilizing the same format, three Q.F.D. projects--Outstanding/Successful, Typical, and Difficult/Unusual--were examined. The major organizations, relationships, goals and postures and procedures were described and discussed for each of these projects.

After the technical and organizational findings were reported, the personal assessment findings were reported. The same three projects and interviewees were utilized as in the organizational assessment. Each of the three Q.F.D. project's key individuals' personal descriptions were compiled and discussed.

An integration of the three assessments was compiled. Similarities between the three assessments regarding Q.F.D. variables included Commitment (top management, organizational and personal), Customer Information Availability, Team Composition and Dynamics, and Q.F.D. Project Completion Time.

Similarities between the three assessments regarding Q.F.D. outcomes included Improved Design and Improved Communications as the major results from utilizing Q.F.D. Improved Cost was only indirectly affected and Improved 
Time-to-Market was not apparently impacted at all. No major discontinuities were found between the three assessments regarding either Q.F.D. variables or outcomes.

Eight conclusions were drawn from the research and five contributions of the research were noted. Five future research recommendations were also made.

\section{SUMMARY}

Eight conclusions were drawn from the research and five contributions of the research were noted. Five future research recommendations were also made. The dissertation's references and supporting appendices are presented next. 


\section{REFERENCES}

1. Adams, Robert M., and Mark D. Gavoor. "Quality Function Deployment: Its Promise and Reality." A.S.Q.C. Quality Congress Transactions (1990): 33-38.

2. Akao, Yoji, ed. Quality Deployment: A Series of Articles. Lawrence, ME: The GOAL/QPC, 1987.

3. ---, ed. Quality Function Deployment: Integrating Customer Requirements into Product Design. Cambridge, MA: Productivity, 1990.

4. ---. "History of Quality Function Deployment in Japan." Annual IAQ Meeting. 22 Oct. 1989. Buenos Aires, Arg.: n.p., n.d. N. pag.

5. --. "Recent Aspects of Quality Function Deployment on Service Industry in Japan." Intl. Conference on Quality Control 1989 Proc. 26-27 Oct. 1989. Rio de Janeiro, Braz.: n.p., n.d. N. pag.

6. Andrews, Frank M., Laura Klem, Terrance N. Davidson, Patrick M. O'Malley, and Willard G. Rodgers. $\underline{A}$ Guide for Selecting Statistical Techniques for Analyzing Social Science Data. Ann Arbor, MI: Survey Research Center of the Inst. for Social Research of $U$ of Michigan, 1975.

7. Aswad, Adnan. "Quality Function Deployment: A Tool or a Philosophy." Int1. Cong. and Exposition Conference Proc. 27 Feb. -3 Mar. 1989. Detroit, MI:

n.P., n.d. N. pag. (See also Society of Automotive Engineering Technical Paper Series No. 890163$.

8. Carey, William R. "Quality Function Deployment." MAPI Products Liability Council Proc. N.p.: n.p., n.d. N. pag.

9. Churchil1, Gilbert A., Jr. "A Paradigm for Developing Better Measures of Marketing Constructs." Jour. of Marketing Research 16 (1979): 64-73. 
10. Churchman, C. West. The Design of Inquiring Systems. New York: Basic, 1971 .

11. Cohen, Lewis. "Quality Function Deployment: An Application Perspective from Digital IEquipment Corporation." National Productivity Rev. 7.3 (1988): 197-208.

12. Conti, Tito. "Process Management and Quality Function Deployment." Quality Progress 22.12 (1989): 4548 .

13. Cronbach, L. J. "Coefficient Alpha and the Internal Structure of Tests." Psychometrika 16 (1951): 297-334.

14. Dawes, Robyn M. Fundamentals of Attitude Measurement. New York: Wiley, 1972 .

15. De Vaus, D. A. Surveys in Social Research. London: Allen, 1986 .

16. De Vera, Dennis, Tom Glennon, Andrew $\mid A$. Kenny, Mohemmad A. H. Khan, and Mike Mayer. "Automotive Case Study." Quality Progress 21.6 (1988): 35-38.

17. Delatore, J. P., E. M. Press, and M. K. Vora. "Translating Customer Needs into Product Specifications." Quality Progress 22.1 (1989): 50-53.

18. Deming, W. Edwards. Out of Crisis. Cambridge: M.I.T. Center for Advanced Engineering Study, 1986.

19. Denton, D. Keith. "Enhance Competitiveness and Customer Satisfaction... Here's One Approach." Industrial Engineering May 1990:| 24-30.

20. Dillman, Don A. Mail and Telephone Surveys: The Total Design Method. New York: Wiley, 1978.

21. Ealey, Lance. "QFD--Bad Name for a Great System." Automotive Industries July 1987:।2.

22. Eureka, William E., and Nancy E. Ryan!. The Customer Driven Company: Managerial Perspectives on QFD. Dearborn, MI: American Supplier Inst. P, 1988.

23. Fosse, Chris. "Quality Assurance Through Strategic Product Development and QFD." Assn. for Manufacturing Excellence 1988 Conference Proc. Aug. 1988. Portland, OR: n.P., n.d. N. pag. 
24. Fortuna, Ronald M. "Beyond Quality: Taking SPC Upstream." Quality Progress 21.6 (1988): 23-28.

25. Gupta, A. K., S. P. Raj, and David Wileman. "A Model for studying $R \& D$ : Marketing Interface in the Product Innovation Process." Jour. of Marketing 50 (1986): 7-17.

26. Hauser, John R., and Don Clausing. "The House of Quality." Harvard Business Rev. 66.3 (1988): 63-73.

27. Hauser, John R., and Robert L. Klein. "Without Good Research, Quality Is a Shot in Dark." Marketing News 22.1 (1988): $1+$.

28. Hofmeister, Kurt, and Bill Slabey. QFD Awareness Seminar. Quality Education and Training Center, Ford Motor Co. May 1989. Detroit: n.p., n.d.

29. -- . QFD Team Training Four Day Workshop. Dearborn, MI: American Supplier Inst., 1988.

30. Huthwaite, Bart. "Designing-In Quality." Quality 27.11 (1988): 34-35.

31. Jackson, Philip C., Philip Klahr, Robert E. Veres, and Lakshmi S. Vora. "TIES: An Engineering Design Methodology and System." Innovative Applications of Artificial Intelligence Conference Proc. 1-3 May 1990. Georgetown U, Washington, DC: n.p., n.d. N. pag. (See also Society of Manufacturing Engineers Technical Paper, TIES, Autofact Conference 1989.)

32. Johne, F. Axel, and Patricia A. Snelson. "Success Factors in Product Innovation: A Selective Review of the Literature." Jour. of Product Innovation Management 5 (1988): $114-28$.

33. Jones, Ken. "A Break with Tradition." Industrial Management 12.4 (1988): 30-32.

34. Kano, Noriaki, Nobuhiku Seraku, Fumio Takahashi, and Shinichi Tsuji. "Attractive Quality and Must-Be Quality." Quality 14.2 (1984): 39-48.

35. Kenny, Andrew A. "New Paradigm for Quality Assurance." Quality Progress 21.6 (1988): 30-32. 
36. Kerlinger, Fred N. Foundations of Behavioral Research. New York: Holt, 1973.

37. King, Bob. Better Designs in Half the Time. Methuen, ME: The GOAL/QPC, 1987.

38. King, Robert. "Listening to the Voice of the Customer: Using the Quality Function Deployment System." Nat1. Productivity Rev. 6.3 (1987): 277-81.

39. Kogure, Masao, and Yoji Akao. "Quality Function Deployment and CWQC in Japan." Quality Progress 16.10 (1983): 25-29.

40. Lansing, John B., and James N. Morgan. Economic Survey Methods. Ann Arbor: Survey Research Center of the Inst. for Social Research of U of Michigan, 1974.

41. Linstone, Harold A. Multiple Perspectives for Decision Making Bridging the Gap Between Analysis and Action. New York: Elsevier Science, 1984.

42. Long, Thomas J., John J. Convey, and Adele R. Chwalek. Completing Dissertations in the Behavioral Sciences and Education. San Francisco: JosseyBass, 1985.

43. Lorsch, Jay $W$., and Paul R. Lawrence. "Organizing for Product Innovation." Harvard Business Rev. 43 (1965): 109-22.

44. Mauch, James E., and Jack W. Birch. Guide to the Successful Thesis and Dissertation. New York: Marcel Dekker, 1989.

45. MCElroy, John. "QFD Building the House of Quality." Automotive Industries January 1989: 30-32.

46. Miser, Hugh J., and Edward S. Quade, eds. Handbook of Systems Analysis, Overview of Uses, Procedures, Applications, and Practice. New York: Elsevier Science, 1985 .

47. Morrel1, Norman E. "Quality Function Deployment." SAE Technical Paper Series No. 870272. Warrendale, PA: Soc. of Automotive Engineers, Feb. 1987. N. pag.

48. Moser, C. A., and G. Kalton. Survey Methods in Social Investigation. London: Heinemann Educational Books, 1971 . 
49. Newman, Richard G. "QFD Involves Buyers/Suppliers." Purchasing World 32.10 (1988): 91-93.

50. Nicholson, Charlie. Quality Function Deployment, Customer Driven Manufacturing, An Overview. Portland, OR: Blount, 1990.

51. Nunnally, Jum C. Psychometric Theory. New York: McGraw, 1978.

52. Peter, J. Paul. "Reliability: A Review of Psychometric Basics and Recent Marketing Practices." Jour. of Marketing Research 16 (1979), 6-17.

53. Quality Function Deployment: A Collection of Presentations and QFD Case Studies. Dearborn, MI: American Supplier Inst. P, n.d.

54. Ross, Philip J. "Role of Taguchi Methods and Design of Experiments in QFD." Quality Progress 21.6 (1988): 41-47.

55. Saraph, Jayant V., P. George Benson, and Roger G. Schroeder. "An Instrument for Measuring the Critical Factors of Quality Management. Decision Sciences 20 (1989): 810-29.

56. Shiraki, Takeshi, and Somi Hibino. "Deployment of Quality Information Ranging from Product Planning to Sales Service." 1984 A.S.Q.C. 28th Annual Stanford Conference Proc. 13 Oct. 1984. Palo Alto, CA: n.p., n.d. N. pag.

57. Shores, Dick. "TQC: Science, Not Witchcraft." Quality Progress 22.4 (1989): 42-45.

58. Siegel, Sidney. Non-Parametric Statistics for the Behavioral Sciences. New York: McGraw, 1956.

59. Sommers, William P. Product Development: New Approaches in the 1980s. New York: Booz-Allen and Hamilton, 1979 .

60. Souder, William E. "Managing Relations Between $R \& D$ and Marketing in the New Product Development Projects." Jour. of Product Innovation Management $5(1988): 6-19$.

61. Srinivasan, V., and Amiya K. Basu, "The Metric Quality of Ordered Categorical Data." Marketing Science $8.3(1989): 205-30$. 
62. Stratton, Brad. "The Refined Focus of Automotive Quality." Quality Progress 1.10 (1989): 47-50.

63. Sullivan, Lawrence P. "Policy Management Through Quality Function Deployment." Quality Progress 21.6 (1988): 18-20.

64. ---. "Quality Function Deployment." Quality Progress $19.6(1986): 39-50$.

65. ---. "Seven Stages in Company-Wide Quality Control." Quality Progress 19.5 (1986): 77-83.

66. Tomlinson, Rolfe, and Istvan Kiss, eds. Rethinking the Process of Operational Research and Systems Analysis. London: Pergamon, 1984.

67. Transactions from a Symposium on Quality Function Deployment. 19-20 June 1989. Novi, MI: Planning Comittee for a Symposium on Quality Function Deployment, n.d.

68. Vasilash, Gary S. "Hearing the Voice of the Customer." Production 101.2 (1989): 66-68.

69. Zaltman, Gerald, Karen Lemasters, and Michael Heffring. Theory Construction in Marketing Some Thoughts on Thinking. New York: Wiley, 1982.

70. Zultner, Richard E. Software Quality Deployment Adapting QFD to Software. Princeton: Zultner, 1989. 
APPENDIX A

THE SUBJECTIVE AND OBJECTIVE

QUALITY CONCEPTS 
This dissertation is concerned with providing information on Q.F.D. In order to provide information on Q.F.D. a thorough grasp of the Q.F.D. process is required. However, to understand the Q.F.D. process, an understanding of the dual nature (subjective and objective) of the word "quality" is required.

Just what is meant when the word quality is used? Even today knowledgeable people in the quality field disagree on the exact definition of the word. It has been widely conjectured that every person would define it differently. However, some major elements of the definition of quality have been agreed upon by thinkers in the quality field. Around 350 B.C. Aristotle wrote on quality. His four definitions were stated in his book titled Metaphysics. John Locke (1632-1704) wrote in Human Intelligence at least two definitions of quality from his perspective. W.A. Shewhart, generally considered to be the founder of statistical quality techniques, clearly classified the various definitions to date into two broad categories. The first category is objective quality; and the second is subjective quality (34).

The objective quality definitions centered around physical properties; for example, conformance to physically 
measurable specifications. The subjective quality definitions centered around feelings; for example, goodness of $f$ it and pleasing looks. These two categories of quality definitions are overlapping and should not be seen as mutually exclusive. The 1950 s to the present day has seen more integrative definitions, such as, products of maximum usefulness and salability (Deming), customer satisfaction (Feigenbaum, Juran, and Ishikawa), and loss to society (Taguchi) (34).

In the past, the product's producers' perspective encouraged the producers to express their quality definition in objective measurements. However, the product's customers' perspective encouraged the customers to express their quality definition in subjective feelings.

The better the product designers 1 isten to the customers, the better the "design quality." The better the producers meet the measurable design targets, the better the "conformance quality." Thus "subjective design quality" and objective conformance quality" are both necessary for overall customer satisfaction to occur. Recognition that both "subjective design quality" and "objective conformance quality" are necessary to achieve overall product quality is very important. It is one of the reasons why the Q.F.D. process has been described:as a powerful quality improvement methodology. 
Notice that the better the "objective conformance quality" measures are tied to the "subjective design quality" feelings, the better the product producers satisfy the customers. Q.F.D. is directed at improving both the understanding of the customer's "subjective design quality" definitions (through a systematic and iterative process) and the translation of these subjective feelings into the producer's "objective conformance quality" measures (through a systematic process). The Q.F.D. process ties "subjective quality" feelings directly to "objective quality" measures.

The Q.F.D. process is described in more detail in Chapter I, so that potential Q.F.D. variables, outcomes, and their relationships may be identified and researched. 
APPENDIX B

A MUITIPLE PERSPECTIVES OVERVIEW 
By its very nature Q.F.D. has both social and technical components. Therefore, both components should be included in an assessment of the Q.F.D. process. In the past, most assessments were done only technically. An excellent summary and overview of the problems with utilizing only a technical perspective for socio-technical problems are presented by Linstone (41). Further, a new approach for improving the analysis of socio-technical situations is developed and presented in this reference. This new approach is known as Multiple Perspectives. A brief review of why Multiple Perspectives is necessary and applicable to the dissertation and an overview of Multiple Perspectives follow.

A development of Frederick Taylor's Scientific Management approach was mankind's increasing reliance upon finding technical solutions to problems. World War II and operations research led to mathematical/statistical approaches to solving system problems. Man's successes in these areas were extrapolated such that all systems were thought to be solvable by systems analysis. However, as socio-technical problems were analyzed and solved using this technical approach, analysts and society noticed that the solutions were not working. 
Decisions are made by organizations and individuals. Their perspectives may be very different from a rational/ technical analyst's. Modes of inquiry and problem solving based solely on a rational/technical approach, inherently, will not be able to discover all insights concerning organizations and individuals. Modes of inquiry and problem solving based on organizational and personal perspectives are necessary to improve the socio-technical problem-solving process (10).

System thinkers found, for example, that some problems probably cannot be solved. Technical analysis implicitly assumes a solution. Some social problems have only tradeoffs with no optimal solution that satisfies everyone. Complex social problems cannot be reduced to sub-problems, which we manage to solve and then reassemble the subsolutions back into a master solution. The complex interactions between social sub-problems prohibit this analytic reductionism and modeling approach from working.

Further, the rational problem analys is approach requires quantifiable information. However, not all social and personal information is easy to quantify. The technical approach actually encourages objectivity and unbiased observation. By purposely ignoring subjective human factors (societal, organizational, and personal), the technical approach encouraged the non-relevance of its "optimum" solution. The investigators also found the rational scientific 
approach did not handle discounting. For example, an individual may be opposed to burying garbage in his backyard, but is not be opposed to burying garbage a hundred miles away (geographical discounting). Another example is time discounting. An action taken today is viewed as having more impact than that same action taken five years from now. Various system thinkers recognized the inadequacy of using only a rational, technical perspective in analyzing problems--especially socio-technical problems. Their literature and thoughts have been reviewed and integrated into the new problem analysis known as Multiple Perspectives (see Figure 6, Evolution and Synthesis of Multiple Perspectives). Multiple Perspectives utilizes multiple modes of inquiry to enrich our understanding of the socio-technical problem which aids in improving decisions about these problems (41).

Multiple Perspectives seeks a balanced viewing of problems. It includes not only the use of the important technical perspective for viewing and understanding a problem, but also the use of an organizational perspective and a personal perspective. These three perspectives are not mutually exclusive, but they use different viewing paradigms and different ways of obtaining input. The technical perspective uses the rational, objective, analytical reductionist paradigm. It gathers its inputs via abstract non-personal, quantifiable means if possible. The organizational perspective uses the dialectic, adversarial 
paradigm similar to courtroom inquiry mode. It gathers its inputs via group conferences, interviews, probing of insiders, examining policy, and/or standard operating procedures. The personal perspective uses the individual reality, experience and intuition paradigm. It gathers its inputs via stories, personal discussions, and narratives. An excellent comparison of the three perspectives is shown in Figure 14, A Multiple Perspectives Comparison (41).

Multiple Perspectives was used in the dissertation's Q.F.D. implementation model's development. Also, it will be used in the assessment of the model's potential variables and outcomes. 
APPENDIX C

Q.F.D. QUESTIONNAIRE 


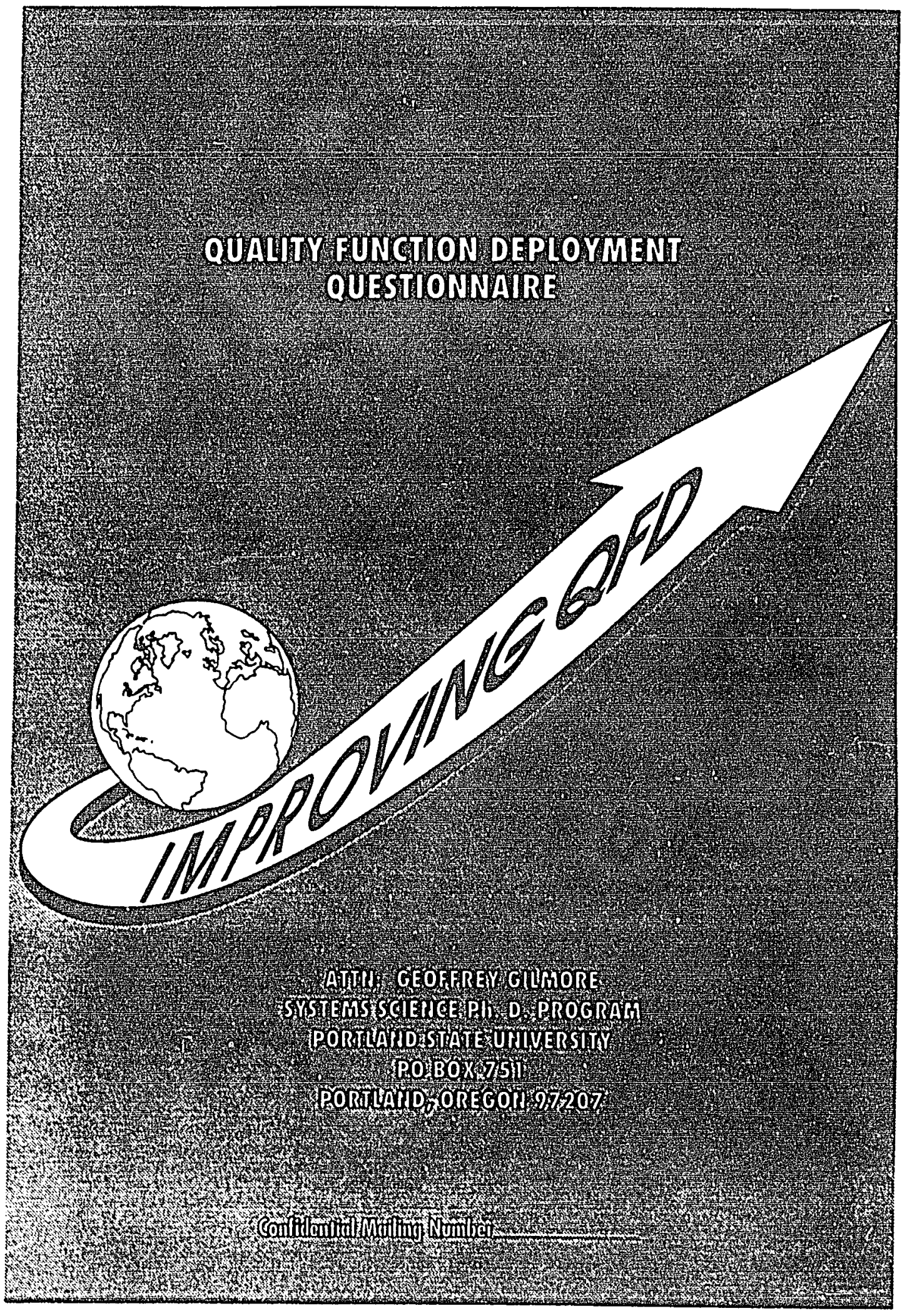


You are being asked to complete the following CONFIDENTIAL questionnaire. Please think back to your Q.F.D. project listed below and answer the questions in regards to only that Q.F.D. project experience.

Q.F.D. Project Number: Description:

\section{SECTION I}

First we would like to ask you some questions about factors which may have affected the Q.F.D. product's design.

In regards to this Q.F.D. project:

\begin{tabular}{|c|}
\hline $\begin{array}{c}\text { How Affected } \\
\text { (Circle your answer) }\end{array}$ \\
\hline
\end{tabular}

1. How did the chart building Strongly product design? . . . . . . . .

2. How did chart size/complexity affect the Q.F.D. product design? .

Impaired Design

Strongly Impaired Design

3. How did gustomer information availability affect the Q.F.D. product design? ........

4. How did competitive information availability affect the Q.F.D. product design?

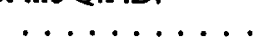

5. How did determining accurate chartweights affect the Q.F.D. product design? . . . . . . . . .

6. How did top management

commitment affect the Q.F.D. product design?

7. How did Q.F.D. project selection affect the Q.F.D. product design? .

8. How did Q.F.D. Leam composition affect the Q.F.D. product design?

9. How did Q.F.D. team size affect the Q.F.D. product design? . . . .

10. How did Q.F.D. team dymamics affect the Q.F.D. product design?
Strongly

Impaired

Design

Strongly

Impaired

Design

Strongly

Impaired

Design

Strongly

Impaired

Design

Strongly

Impaired

Design

Strongly

Impaired

Design

Strongly

Impaired

Design

Surongly

Impaired

Design
Impaired Design

Impaired

Design

Impaired

Impaired

Design

Impaired

Desigo

Impaired

Design

Impaired

Design

Impaired

Design

Impaired Design

Impaired Design

No
Affea
No
Affect

Improved
Design

Strongly Improved Design

Strongly Improved Improved Design Design

No Improved Itrongly Affect Design Desiga

No

$\begin{array}{cc}\text { Improved } & \begin{array}{c}\text { Strongly } \\ \text { Improved } \\ \text { Desiga }\end{array} \\ \text { Design }\end{array}$

Affect

Strongly

No

Improved

Improved

Affect

Design

Design

$\begin{array}{cc}\text { No } & \text { Strongly } \\ \text { Improved }\end{array}$

Affect Desigm

Strongly

No Improved Improved

Affect Design Design

Strongly

No Improved Improved

Affect Design Design

Strongly

No Improved Improved

Aflea Design Design

$\begin{array}{cc}\text { No } & \text { Improved } \\ \text { Affect } & \begin{array}{c}\text { Strongly } \\ \text { Improvign } \\ \text { Design }\end{array}\end{array}$


In regards to this Q.F.D. project:

\section{How Affected \\ (Circle your answer)}

11. How did the Q.F.D. implementation Level/Phase affect the Q.F.D. product design? .

12. How did the Q.F.D. projest completion time affect the Q.F.D. product design? . . . . . . . .

13. How did the Q.F.D. project's visibility affect the Q.F.D. product design? . . . . . . . . .

14. How did an individual's personal Q.F.D. commitment affect the Q.F.D. product design? . . . . .

15. How did an individual's Q.F.D. training and experience affect the Q.F.D. product design? . . . . .

16. How did an individual's personal power affect the Q.F.D. product design? . . . . . . . . . . .

7. How did an individual's available

Q.F.D. work time affect the Q.F.D. product design?

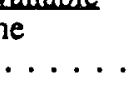

....

\begin{tabular}{|c|c|c|c|c|}
\hline $\begin{array}{l}\text { Strongly } \\
\text { Impaired } \\
\text { Design }\end{array}$ & $\begin{array}{l}\text { Impaired } \\
\text { Design }\end{array}$ & $\begin{array}{l}\text { No } \\
\text { Affect }\end{array}$ & $\begin{array}{l}\text { Improved } \\
\text { Design }\end{array}$ & $\begin{array}{l}\text { Strongly } \\
\text { Improved } \\
\text { Desigen }\end{array}$ \\
\hline $\begin{array}{l}\text { Strongly } \\
\text { Impaired } \\
\text { Design }\end{array}$ & $\begin{array}{l}\text { Impaired } \\
\text { Desigg }\end{array}$ & $\begin{array}{c}\text { No } \\
\text { Affed }\end{array}$ & $\begin{array}{l}\text { Improved } \\
\text { Design }\end{array}$ & $\begin{array}{l}\text { Strongly } \\
\text { Improved } \\
\text { Design }\end{array}$ \\
\hline $\begin{array}{l}\text { Strongly } \\
\text { Impaired } \\
\text { Design }\end{array}$ & $\begin{array}{l}\text { Impaired } \\
\text { Design }\end{array}$ & $\begin{array}{c}\text { No } \\
\text { Affect }\end{array}$ & $\begin{array}{c}\text { Improved } \\
\text { Design }\end{array}$ & $\begin{array}{l}\text { Strongly } \\
\text { Improved } \\
\text { Design }\end{array}$ \\
\hline $\begin{array}{l}\text { Strongly } \\
\text { Impaired } \\
\text { Desigo }\end{array}$ & $\begin{array}{l}\text { Impaired } \\
\text { Design }\end{array}$ & $\begin{array}{c}\text { No } \\
\text { Affect }\end{array}$ & $\begin{array}{l}\text { Improved } \\
\text { Desigg }\end{array}$ & $\begin{array}{l}\text { Strongly } \\
\text { Improved } \\
\text { Desigg }\end{array}$ \\
\hline $\begin{array}{l}\text { Strongly } \\
\text { Impaired } \\
\text { Desige }\end{array}$ & $\begin{array}{l}\text { Impaired } \\
\text { Design }\end{array}$ & $\begin{array}{l}\text { No } \\
\text { Affect }\end{array}$ & $\begin{array}{l}\text { Improved } \\
\text { Desigen }\end{array}$ & $\begin{array}{l}\text { Strongly } \\
\text { Improved } \\
\text { Desigen }\end{array}$ \\
\hline $\begin{array}{l}\text { Strongly } \\
\text { Impaired } \\
\text { Design }\end{array}$ & $\begin{array}{c}\text { Impaired } \\
\text { Design }\end{array}$ & $\begin{array}{l}\text { No } \\
\text { Affect }\end{array}$ & $\begin{array}{c}\text { Improved } \\
\text { Design }\end{array}$ & $\begin{array}{l}\text { Strongly } \\
\text { Improved } \\
\text { Desigen }\end{array}$ \\
\hline $\begin{array}{l}\text { Strongly } \\
\text { Impaired } \\
\text { Design }\end{array}$ & $\begin{array}{l}\text { Impaired } \\
\text { Design }\end{array}$ & $\begin{array}{l}\text { No } \\
\text { Affect }\end{array}$ & $\begin{array}{l}\text { Improved } \\
\text { Design }\end{array}$ & $\begin{array}{l}\text { Strongly } \\
\text { Imprơved } \\
\text { Design }\end{array}$ \\
\hline
\end{tabular}

Second, we would like to ask you some questions about factors which may have affected the Q.F.D. product's cost.

In regards to this Q.F.D. project:

How Afrected

(Circle your answer)

18. How did the chart building methodology affect the Q.F.D. product cost? . . . . . . Cost

Raised Cost

No
Affea
No
Affea

Lowered
Coss
Lowered
Cost

Strongty Lowered

19. How did chart size/complexity affect the Q.F.D. product cost? 
In regards to this Q.F.D. project:

\section{How Affected \\ (Circle your answer)}

\section{How did gustomer information} ayailability affect the Q.F.D. product cost?

Strongly

Strongly

Cost

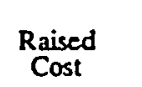

No

No
Affect

Lowered

Strougly

21. How did competitive information axailability affect the Q.F.D. product cost?

Strongly

Raised

Cost

Raised

No
Affect

Cost

Cost

22. How did determining accurate chart weights affect the Q.F.D. product cost? ..........

Strongly

Raised

Cost

Raised

Noff

Lowered

Stroagly

23. How did top management commitment affect the Q.F.D. product cost? . . . . . . . .

Strongly

Strongty

Raised

Raised
Cost

Strongly

Raised

24. How did Q.F.D. project selection
affect the Q.F.D. product cost?

Cost

25. How did Q.F.D. team composition

Strongly

Raised affect the Q.F.D. product cost? .

Cost

26. How did Q.F.D. team size affect the Q.F.D. product cost? . . . .

Strongly

Raised

Raised

Raised
Cost

Cost

Strongly

Raised

27. How did Q.F.D. team dynamics affect the Q.F.D. product cost? .

Cost

\section{Raised}

Cost

Raised

Cost

Raised

Cost

Strongly

Raised

implementation Level/Phase affect the Q.F.D. product cost? .

Cost

Raised

Strongly

Raised

29. How did the Q.F.D. project completion time affect the Q.F.D. product cost? ..........

Cost

Raised
Cost

Strongly

Raised

Cost

Raised
Cost

No
Affect

Lowered
Cost

Strongly

No Lowered Lowered

(1)

No
Affect

Lowered

Strongly

No

No
Affect

Cost

Lowered

Strongly

Lowered Lowered

Cost Cost

No

Lowered Lowered

Affect Cost Cost

No

Noffect

Lowered

Strongly

Cost Lowered

No
Affect

Lowered

Strongly

Cost Cost vest? . . . . . . . . product

Strongly

Raised

Cost

$\underset{\text { Raised }}{\text { Cost }}$

No
Affect

Lowered
Cost

Strongly

Noffect

Cost

Q.F.D. commitment affect the Q.F.D. product cost?

Lowered

Lowered

Cost 
In regards to this Q.F.D. project:

\section{How Afrected \\ (Circle your answer)}

32. How did an individual's Q.F.D. training and experience affect the Q.F.D. product cost? . . . . . .

\begin{tabular}{|c|c|c|c|c|}
\hline $\begin{array}{l}\text { Strongly } \\
\text { Raised } \\
\text { Cost }\end{array}$ & $\begin{array}{l}\text { Raised } \\
\text { Cost }\end{array}$ & $\begin{array}{l}\text { No } \\
\text { Affea }\end{array}$ & $\begin{array}{l}\text { Lowered } \\
\text { Cost }\end{array}$ & $\begin{array}{l}\text { Strongly } \\
\text { Lowered } \\
\text { Cost }\end{array}$ \\
\hline $\begin{array}{l}\text { Strongety } \\
\text { Raised } \\
\text { Cost }\end{array}$ & $\begin{array}{l}\text { Raised } \\
\text { Cost }\end{array}$ & $\begin{array}{l}\text { No } \\
\text { Affeat }\end{array}$ & $\begin{array}{l}\text { Loprered } \\
\text { Cost }\end{array}$ & $\begin{array}{l}\text { Surongly } \\
\text { Lowered } \\
\text { Cost }\end{array}$ \\
\hline $\begin{array}{l}\text { Strongly } \\
\text { Raised } \\
\text { Cost }\end{array}$ & $\begin{array}{l}\text { Raised } \\
\text { Cost }\end{array}$ & $\begin{array}{c}\text { No } \\
\text { Affeat }\end{array}$ & $\begin{array}{l}\text { Lowered } \\
\text { Cost }\end{array}$ & $\begin{array}{l}\text { Surongly } \\
\text { Lowered } \\
\text { Cost }\end{array}$ \\
\hline
\end{tabular}

Third, we would like to ask you some questions about factors which may have affected the Q.F.D. product's time-to-market.

In regards to this Q.F.D. project:

\section{How Afrected \\ (Circle your answer)}

35. How did the chart building methodology affect the Q.F.D. time-to-market? ..........

Strongly Increased Increased

No
Affect

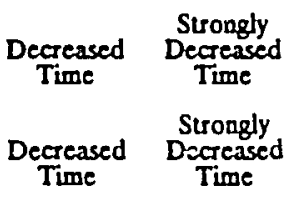

36. How did chart size/complexity affect the Q.F.D. time-to-market?

Strongly
Increased Increased Time

Increased

No
Affect

37. How did gustomer information availability affect the Q.F.D. time-to-market?

Strongly
Incteased

Afrect

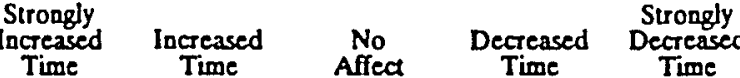

Strongly Time Time

Affect

Time

Time

38. How did competitive information availability affect the Q.F.D. time-to-market?

Strongly Increased Time

Increased Time

$$
\begin{aligned}
& \text { No } \\
& \text { Affect }
\end{aligned}
$$

Decreased
Time

Strongly
Decreased Time

39. How did determining accurate chant weights affect the Q.F.D. time-to-market?

Strongly Increased Time

Increased Time

No

Decreased
Time

Strongly
Decreased

40. How did top management

commiment affect the Q.F.D. $\quad \begin{gathered}\text { Strongly } \\ \text { Increased }\end{gathered}$ commiment affect the Q.F.D. Increased
Increased
Time

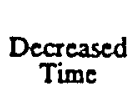

Strongly Decreased 
In regards to this Q.F.D. project:

\section{How ATrected (Circle your answer)}

-

41. How did Q.F.D. project selestion affect the Q.F.D. time-to-market?

42. How did Q.F.D. team composition affect the Q.F.D. time-to-market?

43. How did Q.F.D. team size affect the Q.F.D. time-to-market? . . .

44. How did Q.F.D. team dynamics affect the Q.F.D. time-to-market?

45. How did the Q.F.D.

implementation Level/Phase affect the Q.F.D. time-to-market?

46. How did the Q.F.D. proiect completion time affect the Q.F.D. time-to-market?

Strongly
Increased
Time
Strongly
Increased
Time
Strongly
Increased
Time
Strongly
Increased
Time

Strongly Treased

Increased Time
Timeased

No No
Affect
Decreased Time

Strongly Increased

Decreased
Time

Time

How did the Q.F.D. project's yisibility affect the Q.F.D. time-to-market?

Strongly
Increased

Increased

Increased

No

Time

Affect

Increased

No

Time

Affect

Increased

No

Time

Affect

Decreased
Time

Strongly

Decreased

Time

Time Time

Decreased Dectroasedy

Time

How did an individual's personal Q.F.D. commitment affect the Q.F.D. time-to-market? . . . . .

Strongly

Increased

Time

Increased
Time

No
Affec

$\underset{\text { Decreased }}{\text { Time }}$

Strongly

Time Affea

Decreased
Time

Strongly

Increased

Increased

No
Affect

Decreased
Time

Strongly

Time

Decreased

Strongly Increased

Increased

No
Affec

Decreased
Time

Strongty Time

Decteased

Time

Increased
Time

Increased

No

$\underset{\substack{\text { Decreased } \\ \text { Time }}}{\text {. }}$

Strongly Time

Affect

Decreased

49. How did an individual's Q.F.D. raining and experience affect the Q.F.D. time-to-market? . . . . .

Strongly increased Time

Increased

No
Affect

Decreased
Time

Strongly Time

50. How did an individual's personal power affect the Q.F.D. time-to-market?

Strongly

Increased

Time

Increased

$\underset{\text { Noffect }}{\text { No }}$

Decreased
Time

Time

51. How did an individual's available

Q.F.D. work time affect the

Strongly Increased

Increased Time

No
Affect

Decreased

Time

Strongty 
Fourth, we would like to ask you some questions about factors which may have affected the Q.F.D. product's communications and documentation effort.

\begin{tabular}{|c|}
\hline $\begin{array}{c}\text { How Affected } \\
\text { (Circle your answer) }\end{array}$ \\
\hline
\end{tabular}

In regards to this Q.F.D. project:

52. How did the chart building methodology affect the Q.F documentation effort? ........

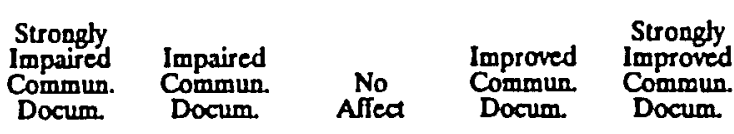

53. How did chart size/complexity

Alfed

Docum. affect the Q.F.D. product communications and documentation effort? . . . . . .

Strongly, Impaired Commun.

4. How did gustomer information availability affect the Q.F.D. product communications and documentation effort? . . . . . . . Docum.

Impaired Commun. Docum.

55. How did competitive information availability affect the Q.F.D. product communications and documentation effort? . . . . . . .

Strongly, Impaired Commun. Docum.

Strongly Impaired Commun. Docum.

56. How did determining accurate chareweighes affect the Q.F.D. product communications and documentation effort? . . . . . .

Strongly Impaired Commun. Docum.

57. How did top management commitment affect the Q.F.D. product communications and documentation effort? . . . . . .

Strongly

lmpaired

Docum.

No
Affect

Improved

Strongly Improved Docum.

58. How did Q.F.D. project selection affect the Q.F.D. product communications and

Strongly Impaired Commun. documentation effort? ........

Docum.

59. How did Q.F.D. team complesition affect the Q.F.D. product communications and

Strongly documentation effort? .......
Impaired

Commun.
Impaired Commun. Docum.

Impaired
Commun.
Docum.

Impaired

Commun

Docum.

No
Affect

Improved

Improved

Strongly Improved Commun. Docum.

Strongly Improved No
Affect Dommun. Commun.

Impaired Commun. Docum.

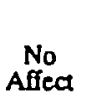

Improved

Strongly

Afea Docum. Docum.

Impaired Commun.

No
Affect

Improved

Strongly Improved

Commun.

Commun.

Docum.

Docum.

No

Improved

Strongly
Improved

Commun Commun.

Docum.

Docum.

Impaired Commun.
Docum.
Strongly

Improved Improved Improved Commun. Commun.
Docum.
No
Affect 
In regards to this Q.F.D. project:

\section{How Affected \\ (Circle your answer)}

60. How did Q.F.D. team size affect the Q.F.D. product

communications and

documentation effort? .........

Strongly

Impaired

Commun.

Docum.

Impaired

Docum.

No
Afied

Improved

Strongly
Improved

Improved

61. How did Q.F.D. team dynamics affect the Q.F.D. product

communications and

Strongly

Impaired

documentation effort? ....... Docum.

Impaired

Docum.

Docum.

Docum.

62. How did the Q.F.D. implementation Level/Phase affect the Q.F.D. product communications and

Strongly

Impaired

Commun.

Impaired

documentation effort? . . . . . .

Docum.

Commun

Strongly

63. How did the Q.F.D. proiec

completion time affect the Q.F.D. product communications and

documentation effort? . . . . . .

Impaired

Commun.

Docum.

Impaired

Commun.

Docum.

No

Affect

Improved

Commun.

Strongly

Improved

Commun.

Docum.

64. How did the Q.F.D. project's visibility affect the Q.F.D. product communications and

Strongly

Impaired

documentation effort? . . . . .

Commun.

Impaired

No

Docum.

65. How did an individual's personal Q.F.D. commitment affect the

Q.F.D. product communications and documentation effort?

Strongly

Impaired

Commun.

Docurn.

Commun.

Docum.

No

Improved

Strongly

Improved

No Commun.

Commun.

Docum.

66. How did an individual's Q.F.D. training and experience affect the Q.F.D. product communications

Sirongly

Impaired and documentation effort? ...

Commun.

Docum.

Impaired

Commun.

Impaired

Commun.

Docum.

Affect

Docum.

Improved Strongly

Commun. Commun.

Docum.

67. How did an individual's personal power affect the Q.F.D. product communications and

Strongly

Impaired documentation effort?

Commun.

Docum.

Improved
Commun.
Docum.

Strongly

Improved

Commun.

Docum.

68. How did an individual's available

Q.F.D. work time affect the

Q.F.D. product communications and documentation effort?

Strongly

Impaired

Commun.

Docum.

Impaired

Commun.

Docum.

No

Improved

Strongly

Improved

Commun.

Strongly

Improved

Commun.

Docum.

Affect

Commun.

Docum.

Strongly
Improved

Improved Improved

No
Affect Dommun.

Docum.

Impaired

No

Improved

Strongly

Improved

Commun.

Docum.

Docum. 


\section{SECTION II}

Now we would like to ask you a few questions on your Q.F.D. process experience.

When compared to prior non-Q.F.D.

Degree of Improvement

(Circle your answer)

experiences/processes:

69. To what degree did the Q.F.D. process improve the product's design? . . . . . . . . . . .

\begin{tabular}{|c|c|c|c|c|}
\hline $\begin{array}{l}\text { Much } \\
\text { Worse }\end{array}$ & Worse & Same & Better & $\begin{array}{l}\text { Much } \\
\text { Better }\end{array}$ \\
\hline $\begin{array}{l}\text { Much } \\
\text { Higher } \\
\text { Cost }\end{array}$ & $\begin{array}{l}\text { Higher } \\
\text { Cost }\end{array}$ & $\begin{array}{l}\text { Same } \\
\text { Cost }\end{array}$ & $\begin{array}{l}\text { Lower } \\
\text { Cost }\end{array}$ & $\begin{array}{l}\text { Much } \\
\text { Lower } \\
\text { Cost }\end{array}$ \\
\hline $\begin{array}{l}\text { Much } \\
\text { Longer } \\
\text { Time }\end{array}$ & $\begin{array}{l}\text { Longer } \\
\text { Time }\end{array}$ & $\begin{array}{l}\text { Same } \\
\text { Time }\end{array}$ & $\begin{array}{c}\text { Shorter } \\
\text { Time }\end{array}$ & $\begin{array}{l}\text { Much } \\
\text { Shoorter } \\
\text { Time }\end{array}$ \\
\hline
\end{tabular}

70. To what degree did the Q.F.D. process reduce the product's costs?

71. To what degree did the Q.F.D. process reduce the product's
ime-to-markel?

the Q.F.D.

72. To what degree did the Q.F.D.
process improve the product's project communicapions and documentation? . . . . . . . . .

\section{SECTION III}

Finally, we would like to ask you to provide some measurements about this Q.F.D. project.

73. a. Approximately how many customer wants (chart's horizontal) end items were used in this Q.F.D. project?

Primary chart rows (end items)

b. Approximately how many product design features (chart's vertical) end items were used in this Q.F.D. project?

Primary chart columns (end items)

74. Approximately what percentage of the necessary customer information was available to support this Q.F.D. project? 
75. Approximately what percentage of the necessary competitive information was available to support this Q.F.D. project?

$\%$

76. Approximately how many people, including yourself, did your Q.F.D. core team include? People

77. What was the Q.F.D. Level/Phase that this Q.F.D. project completed? (check one box)

$\square$ Completed through Level/Phase 1 -Product Planning

Completed through Level/Phase 2 - Product Design

Completed through Level/Phase 3 - Process Planning

$\square$ Completed through Level/Phase 4 - Production Controls Manufacturing

78. Approximately how many months did this Q.F.D. project last?

Months 
What else would you like to tell the researchers concerning this Q.F.D. project?

Your contribution to this important research on Q.F.D. is greatly appreciated. Improving Q.F.D. and its implementation is of vital importance to sales, profits, and jobs. Thank you!

Please return this questionnaire to:

Attention: Geoffrey P. Gilmore

SYSTEM SCIENCE Ph.D. PROGRAM

PORTLAND STATE UNIVERSITY

P.O. Box 751

Portland, Oregon 97207 


\section{APPENDIX D}

ASSOCIATED Q.F.D. QUESTIONNAIRE DOCUMENTS:

ONE-WEEK POST CARD FOLLOW-UP, THREE-WEEK

COVER LETTER FOLLOW-UP AND SEVEN-WEEK

COVER LETTER FOLLOW-UP 
PORTLAND STATE UNIVERSITY

SYSTEMS SCIENCE PH.D. PROGRAM

Portland, Oregon 97207

January 14,1991

John Doe

Company Address

Dearborn, Michigan 18428

Last week a questionnaire seeking your knowledge of Quality Function Deployment (Q.F.D.) was mailed to you.

If you have already completed and returned the questionnaire, please accept our sincere thanks. If not, please do so today. Because you were a Q.F.D. project team leader, your knowledge is vital to this research on improving Q.F.D.

If by some chance you did not receive the questionnaire, or j.t got misplaced, please call me right away at (503) 6598750 , extension 237 , and I will get another one in the mail to you today.

Sincerely,

Geoffrey P. Gilmore

Project Director 
PORTLAND STATE UNIVERSITY

SYSTEMS SCIENCE PH.D PROGRAM

Portland, Oregon 97207

January 28, 1991

John Doe

Company Address

Dearborn, Michigan 18428

About three weeks ago I wrote to you seeking your knowledge of Quality Function Deployment (Q.F.D.). As of today I have yet to receive your completed questionnaire.

Our research purpose is to determine Q.F.D. variables, outcomes, and their relationships in order to improve Q.F.D. and its implementation. With billions of dollars in sales and profits (and millions of jobs) depending upon improving customer satisfaction, improving Q.F.D. and its implementation is vitally important.

I am writing you again because of the significance each questionnaire has to the importance of this study. Your participation as an experienced Q.F.D. project team leader is crucial to our results. We have only a limited number of experienced Q.F.D. project team leaders who may provide the necessary information for this study. It is essential that each Q.F.D. project team leader return their questionnaire.

In the event that your confidential questionnaire has been misplaced, a replacement is enclosed.

Your cooperation is greatly appreciated.

Sincerely,

Geoffrey P. Gilmore

Project Director

P.S. A number of people have written to ask how they may receive a summary of the study's results. You may contact your Corporate Q.F.D. Coordinator, Hal Schaal, for a summary of the study's results. Your confidentiality will be protected; only a summary of the study's results will be provided to those persons expressing an interest in the study. 
PORTLAND STATE UNIVERSITY

SYSTEMS SCIENCE PH.D PROGRAM

Portland, Oregon 97207

February 25, 1991

John Doe

Company Address

Dearborn, Michigan 18428

I am writing to you about our study on determining Quality Function Deployment's (Q.F.D.) variables, outcomes, and their relationships. We recently discussed over the telephone your commitment to complete a Q.F.D. questionnaire.

The limited number of experienced Q.F.D. project team leaders means that your response is very important to the research study. We will not have as accurate an assessment of Q.F.D. implementation without your response.

This is the first known research study designed to improve Q.F.D. and its implementation in either America or Japan. Therefore, the results are of particular importance to all companies currently using Q.F.D. Again, the accuracy of our Q.F.D. assessment will be improved by your response.

It is for these reasons that I have contacted you personally. In case our previous correspondence did not reach you, a replacement questionnaire is enclosed. May I urge you to complete and return the confidential questionnaire as quickly as possible.

If you wish a summary of the study's results, you may contact your Corporate Q.F.D. Coordinator, Hal Schaal.

Your contribution to the success of this study will be greatly appreciated.

Sincerely,

Geoffrey P. Gilmore

Project Director 
APPENDIX E

POTENTIAL QUESTIONS FOR Q.F.D. INTERVIEWS 


\section{Potential Organizational Questions:}

1. What groups were involved in this Q.F.D. project?

(So these groups participated in the Q.F.D. project?)

2. How did groups affect this Q.F.D. project?

(So this group affected Q.F.D. how?)

3. How did the Q.F.D. team get organized?

(So it was organized by . . .?)

4. Did the Q.F.D. team get any policy or procedure guidelines from anyone?

(So the standard policy/procedure of . . . ?)

5. How did the Q.F.D. team function?

(So the team functioned...?)

6. How did the teams' project turn out?

(Then the project turned out...?)

\section{Potential Personal Questions:}

7. How do you feel about Q.F.D.?

(So you feel Q.F.D. . . ?)

8. Would you describe some Q.F.D. project benefits/ detriments?

(Why do you say that? Would you elaborate on that?)

9. Would you describe the Q.F.D. team members for me? (So contributed to ?)

10. How much training and experience in Q.F.D. did you all have?

(So you had training and experience?)

11. How much time was available to work on this Q.F.D. project?
(So everyone had time available?)

12. Were there any other key team members excluding yourself?

(So was a key player?)

13. Who else would you recommend that I talk with?

(Why would they be important to see?)

NOTE: Not all questions may be asked as the interviewer shall be opportunistic and adapt the interview to follow the leads provided by the interviewees. Top, middle, and bottom Q.F.D. team personnel will be interviewed to obtain several different outlooks on the Q.F.D. project. 
APPENDIX F

QUESTIONNAIRE Q.F.D. VARIABLE/OUTCOME HISTOGRAMS 

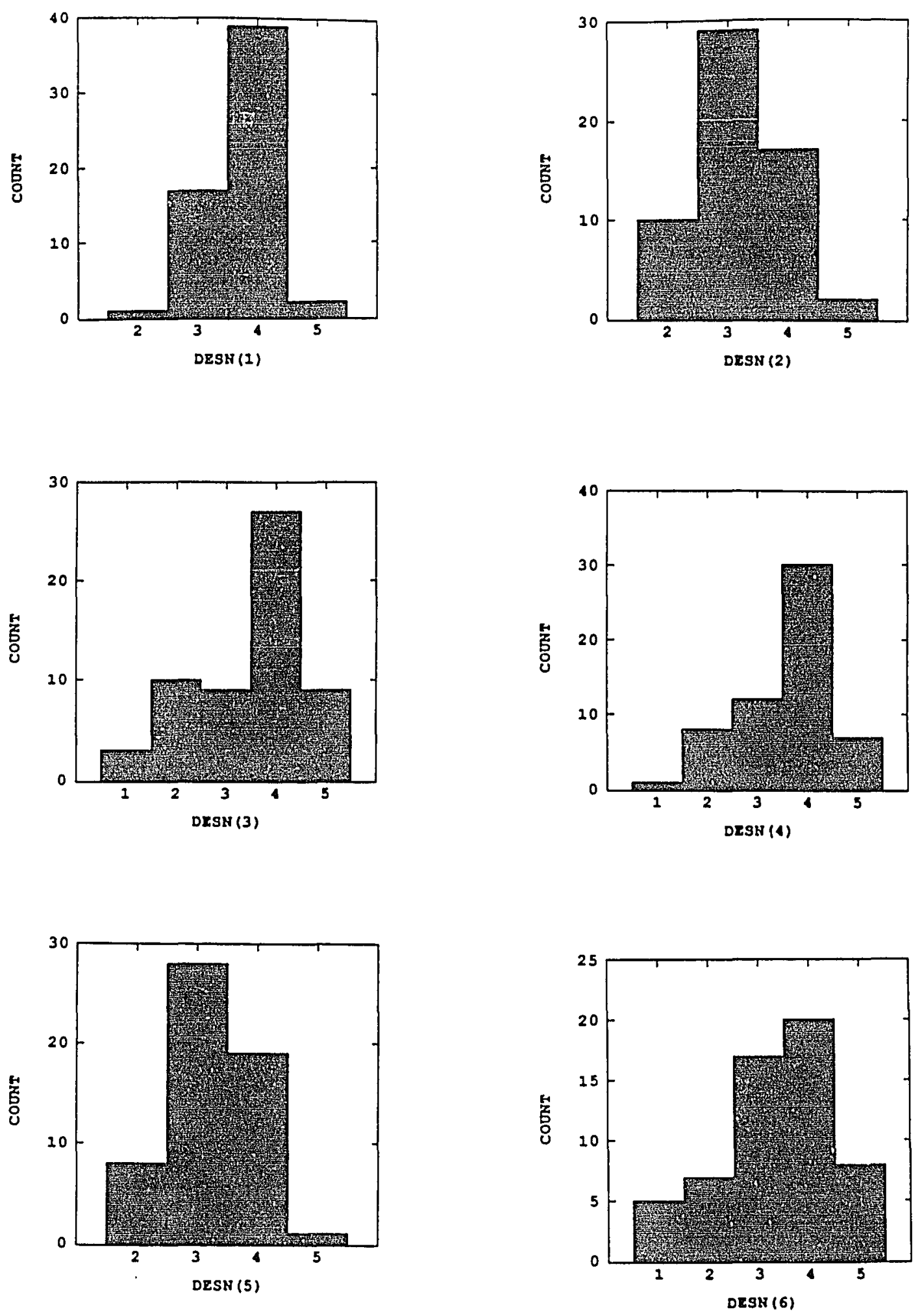

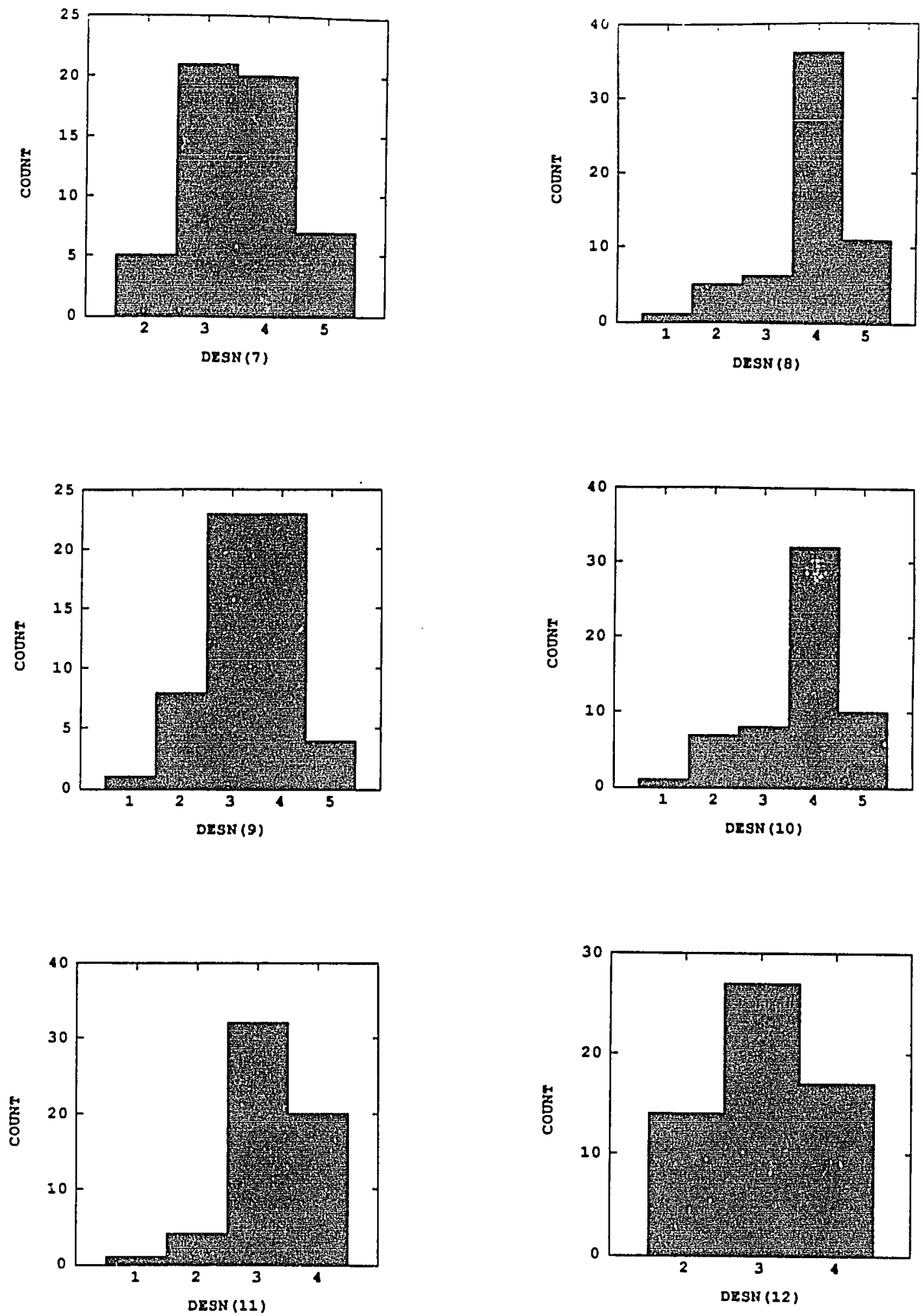

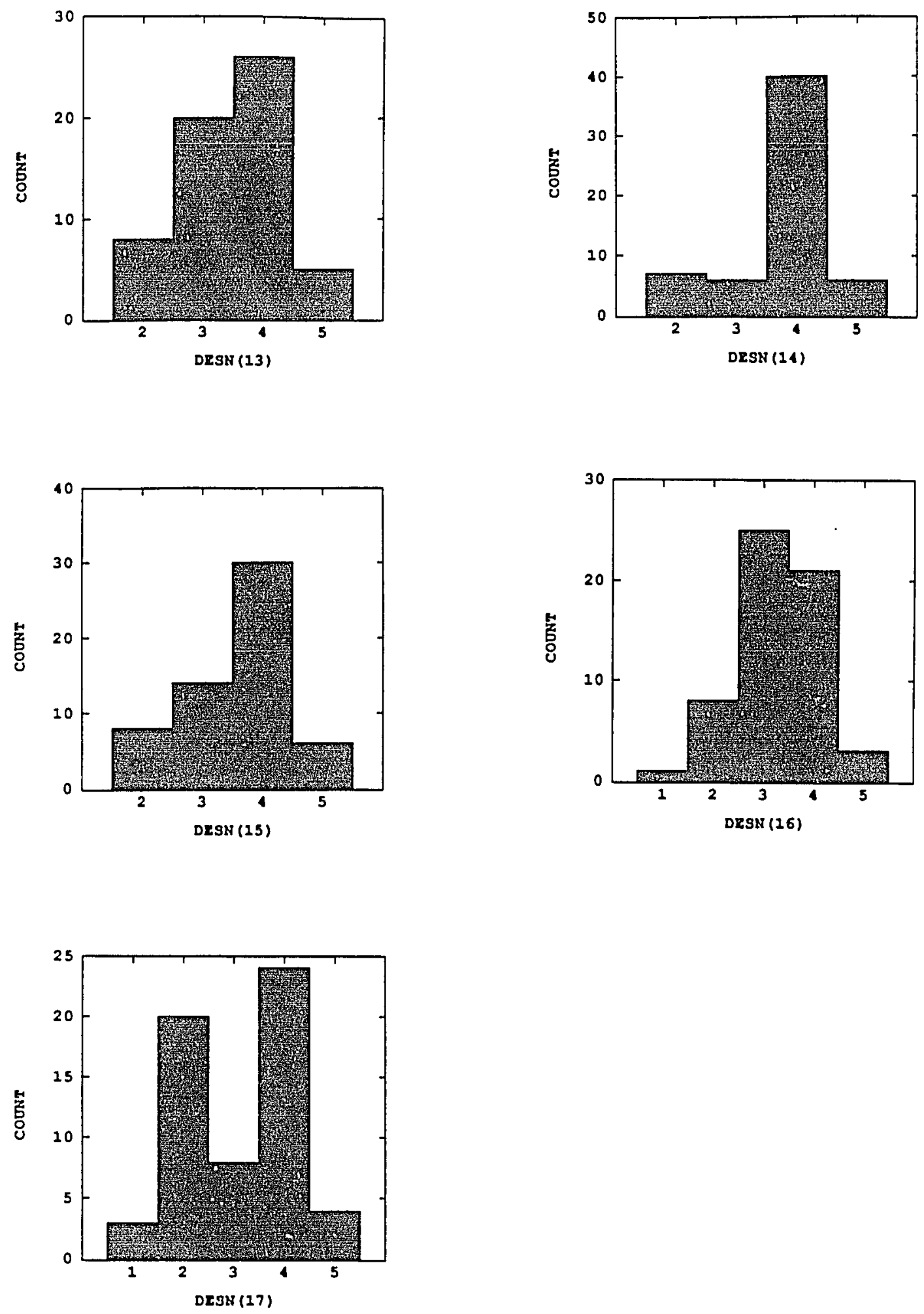

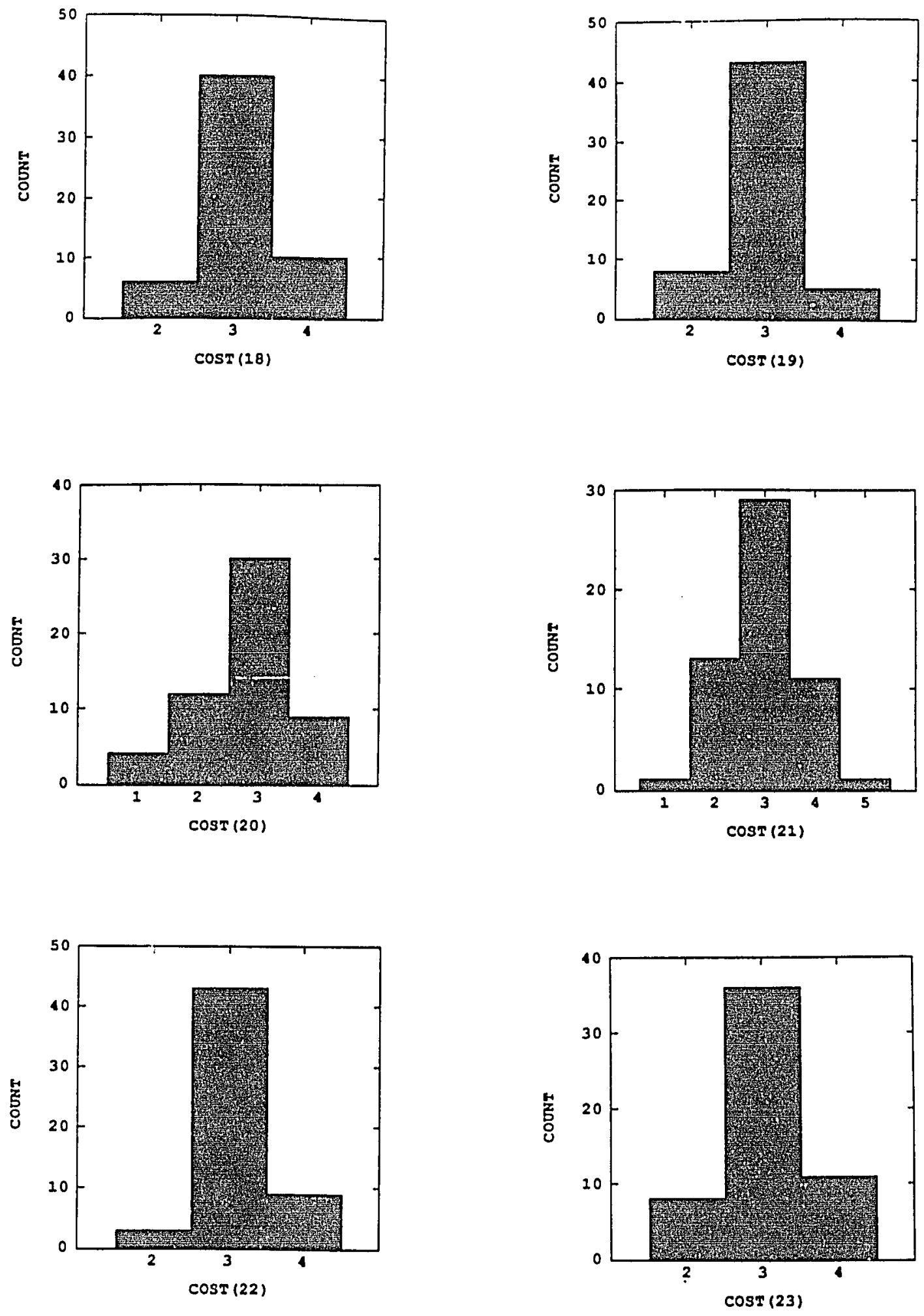

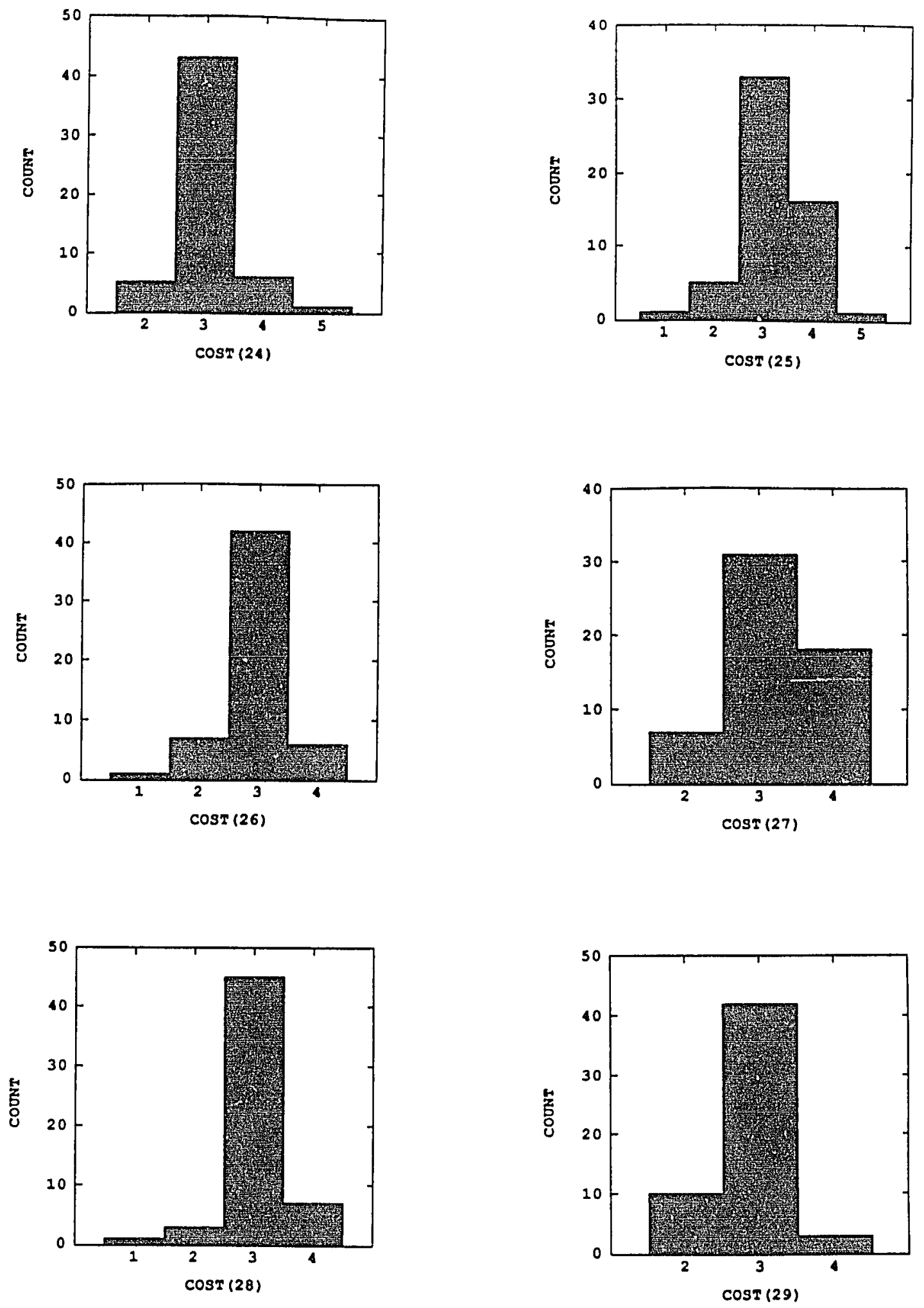

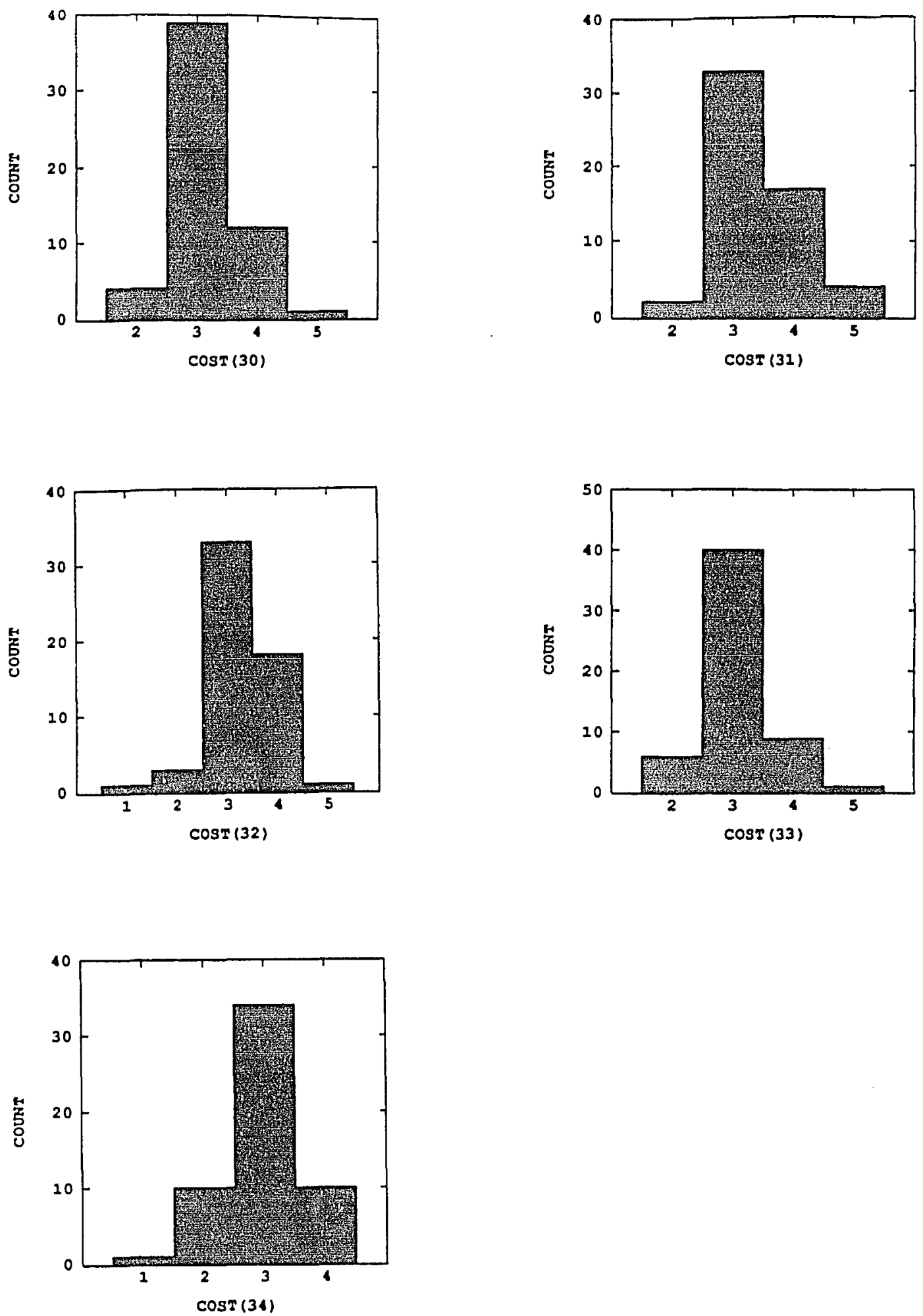

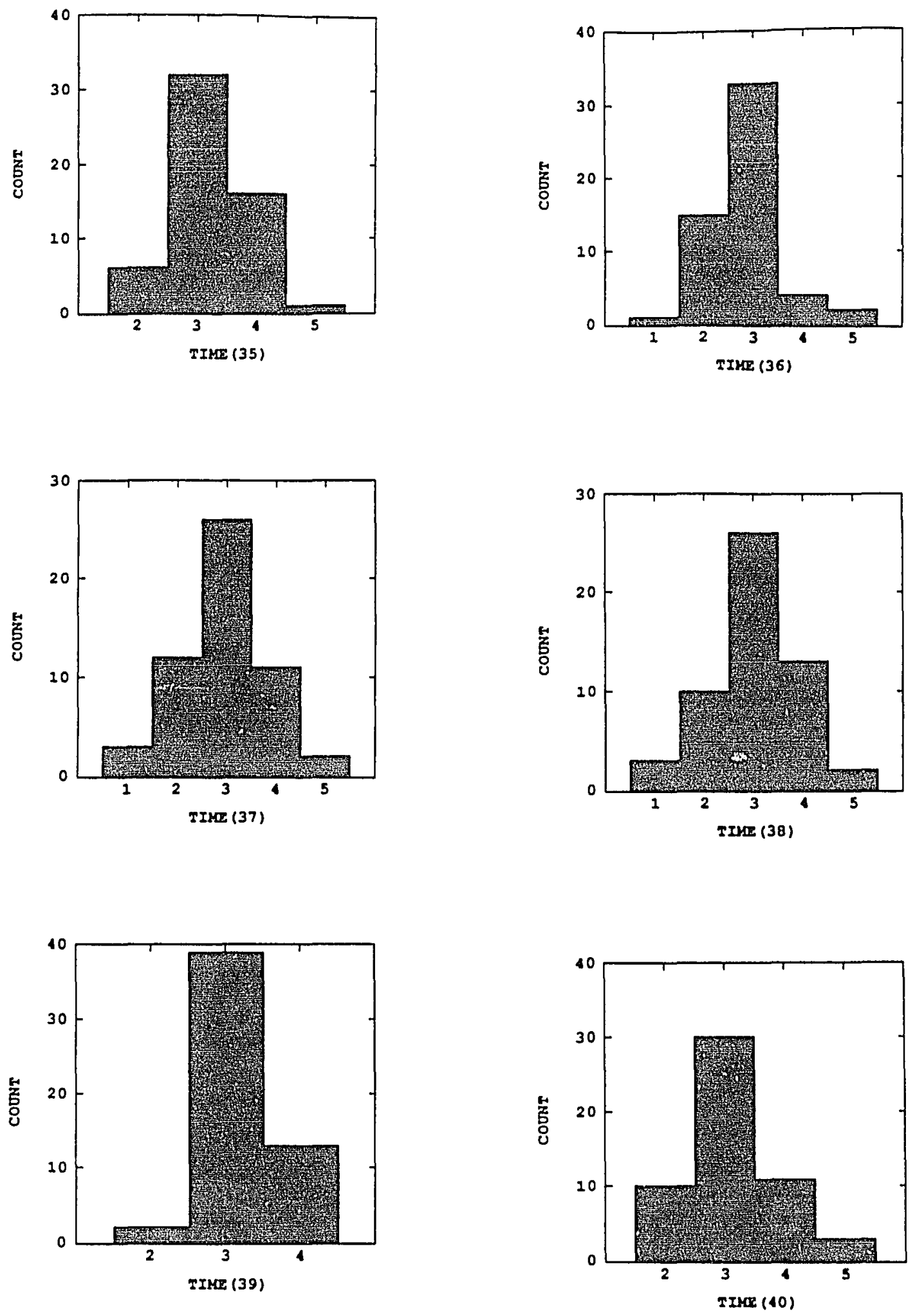

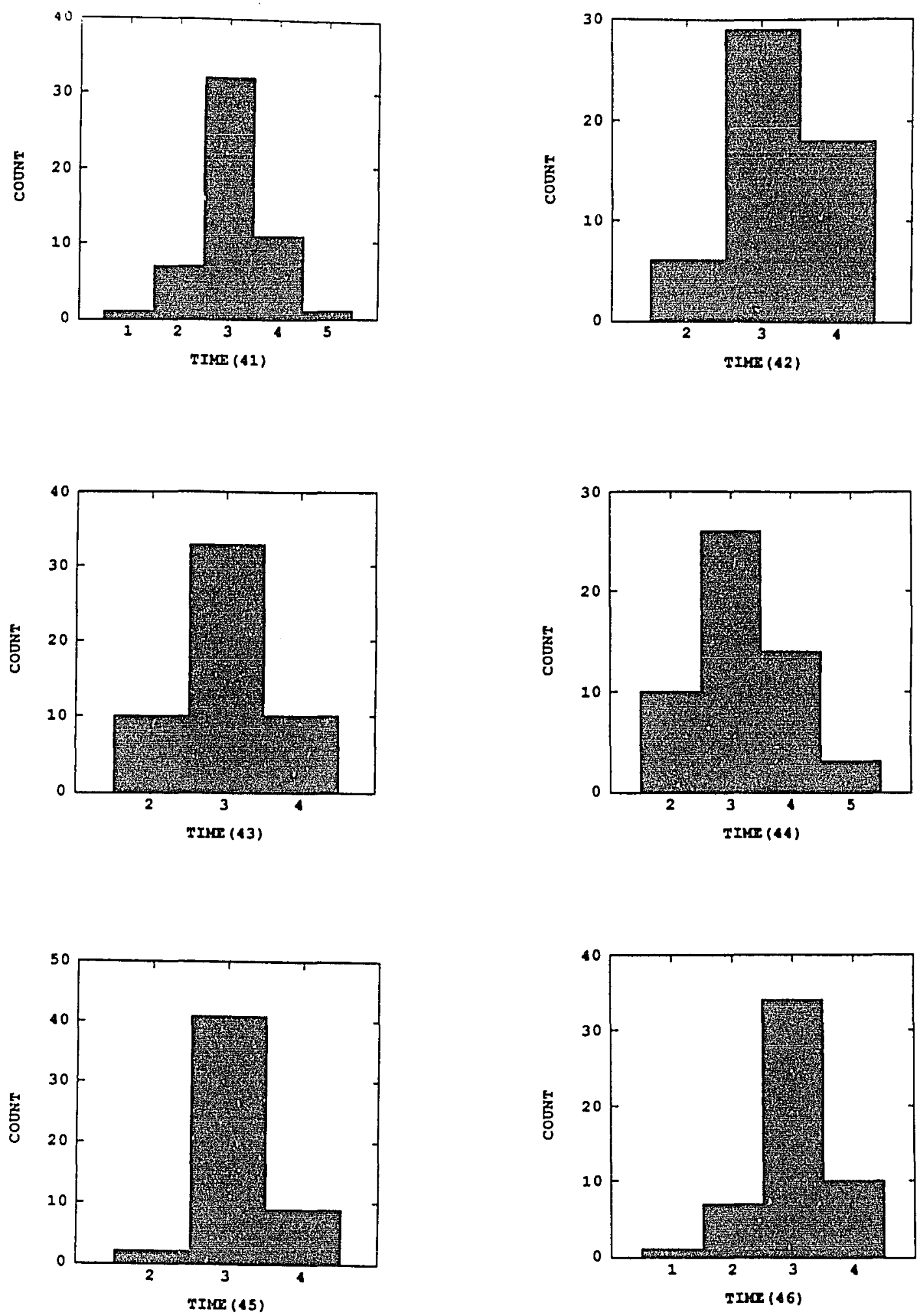

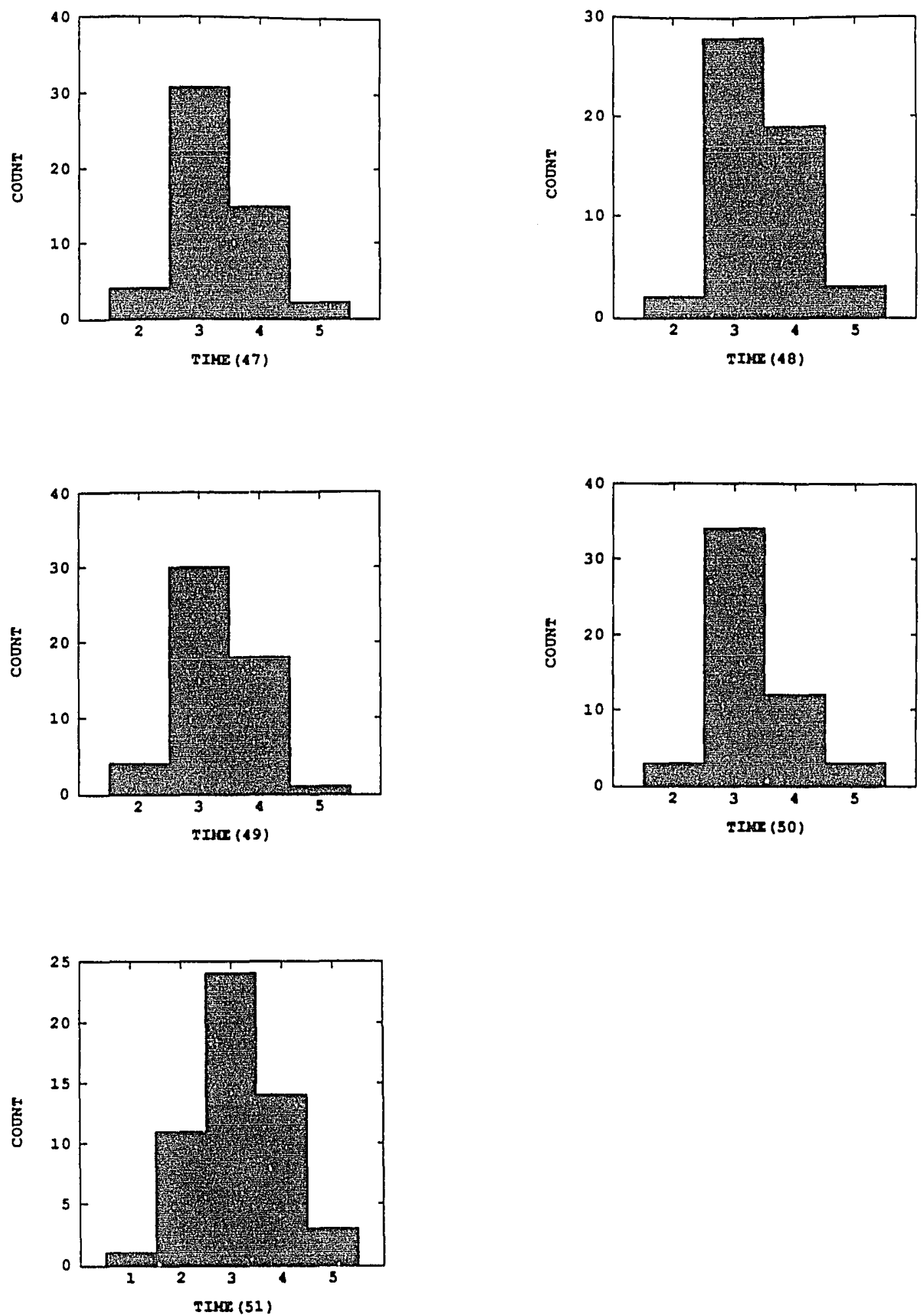

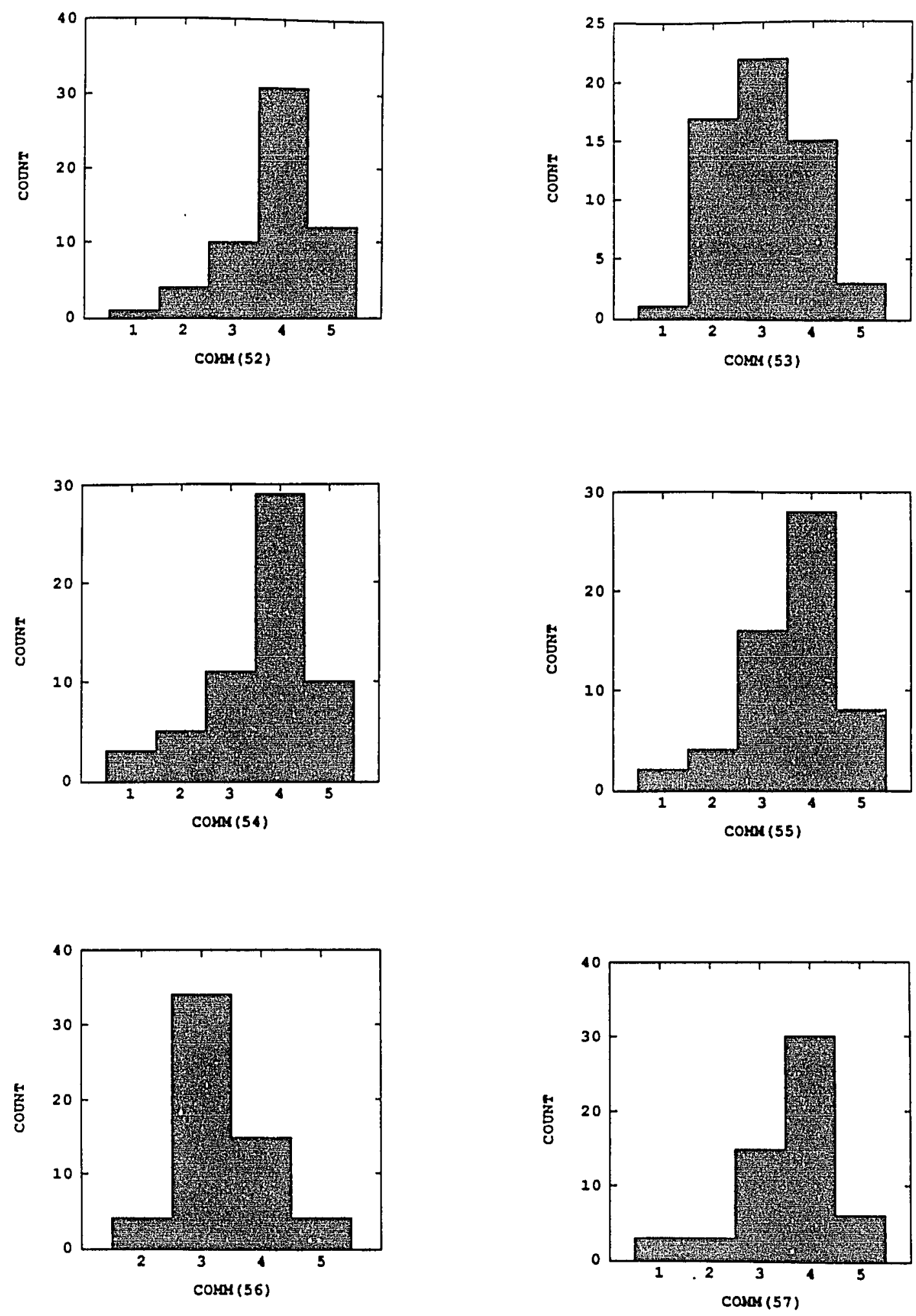

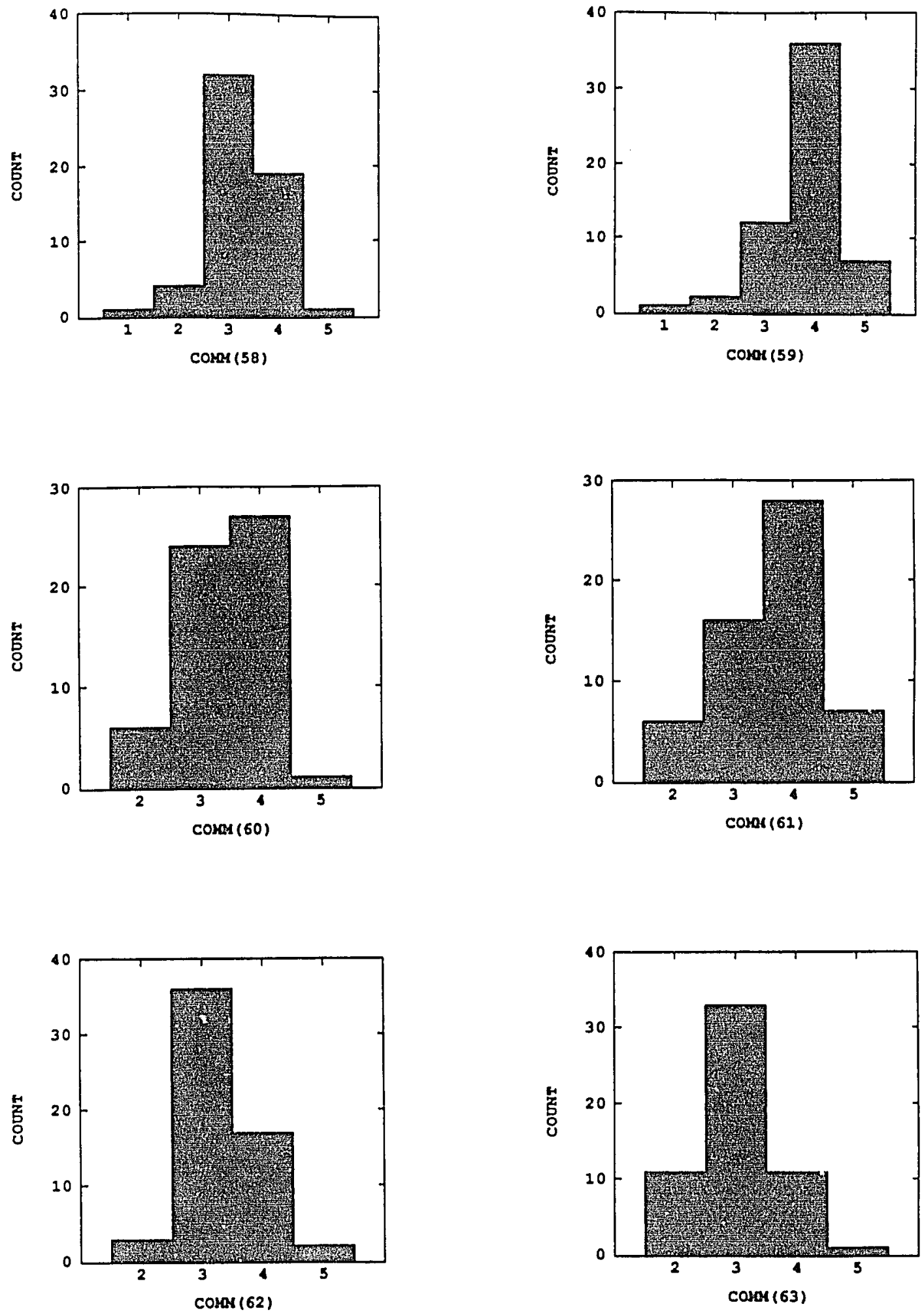

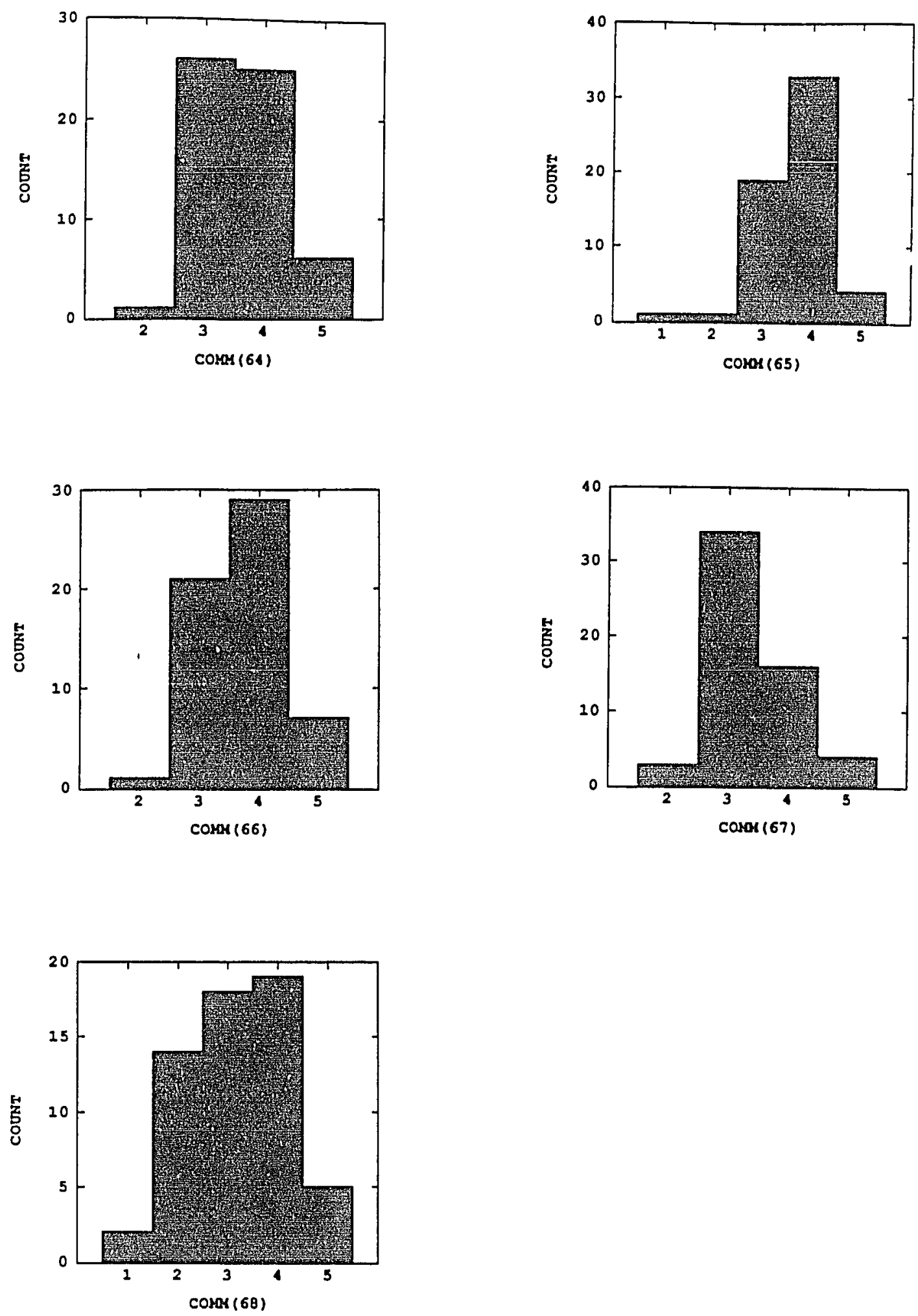

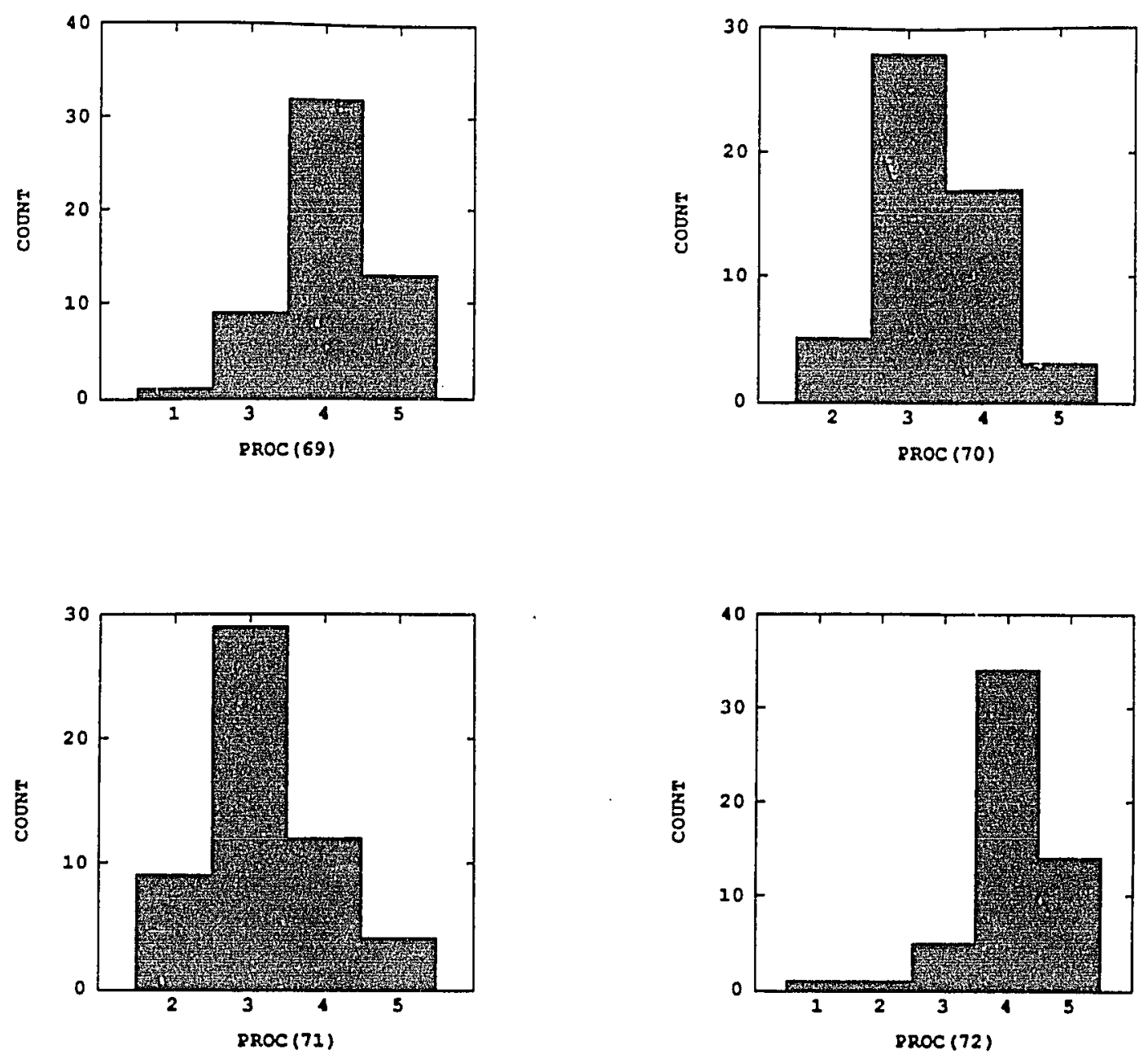
APPENDIX G

Q.F.D. VARIABLES FACTOR ANALYSES 
ITERATIVE PRINCIPAL AXIS FACTOR ANALYSIS

$\begin{array}{cc}\text { ITERATION MAXIMUM CHANGE IN COMMUNALITIES } \\ 1 & 0.8083 \\ 2 & 0.3505 \\ 3 & 0.0513 \\ 4 & 0.0167 \\ 5 & 0.0064 \\ 6 & 0.0040 \\ 7 & 0.0025 \\ 8 & 0.0015 \\ 9 & 0.0009\end{array}$

FINAL COMMUNALITY ESTIMATES

$\begin{array}{ll}1 & 2 \\ 0.086 & 0.130\end{array}$

LATENT ROOTS (EIGENVALUES)

$\begin{array}{lllll}1 & 2 & 3 & 4 & 5 \\ 4.361 & 1.703 & 0.944 & 0.624 & 0.359 \\ 6 & 7 & 8 & 9 & 10 \\ 0.177 & 0.083 & 0.032 & -0.002 & -0.092 \\ 12 & 12 & 13 & 14 & 15 \\ -0.127 & -0.139 & -0.196 & -0.368 & -0.393 \\ 16 & 17 & & & \\ -0.424 & -0.478 & & & \end{array}$


FACTOR PATTERN

$\begin{array}{lll} & 1 & 2 \\ & & \\ \operatorname{DESN}(10) & 0.776 & -0.157 \\ \operatorname{DESN}(13) & 0.765 & -0.130 \\ \operatorname{DESN}(6) & 0.717 & -0.128 \\ \operatorname{DESN}(9) & 0.682 & -0.070 \\ \operatorname{DESN}(7) & 0.659 & -0.276 \\ \operatorname{DESN}(14) & 0.601 & -0.031 \\ \operatorname{DESN}(8) & 0.595 & -0.346 \\ \operatorname{DESN}(3) & 0.114 & 0.683 \\ \operatorname{DESN}(4) & 0.044 & 0.582 \\ \operatorname{DESN}(17) & 0.455 & 0.479 \\ \operatorname{DESN}(12) & 0.316 & 0.395 \\ \operatorname{DESN}(5) & 0.158 & 0.332 \\ \operatorname{DESN}(16) & 0.497 & 0.316 \\ \operatorname{DESN}(2) & 0.316 & 0.175 \\ \operatorname{DESN}(11) & 0.427 & 0.083 \\ \operatorname{DESN}(15) & 0.292 & 0.060 \\ \operatorname{DESN}(1) & 0.293 & 0.009\end{array}$

VARIANCE EXPLAINED BY FACTORS

1

$4.361 \quad 1.703$

PERCENT OF TOTAL VARIANCE EXPLAINED

1

2

$25.655 \quad 10.017$

ROTATED FACTOR PATTERN

2

$\begin{array}{lrr}\operatorname{DESN}(10) & 0.787 & 0.082 \\ \operatorname{DESN}(13) & 0.768 & 0.105 \\ \operatorname{DESN}(6) & 0.722 & 0.093 \\ \operatorname{DESN}(7) & 0.712 & -0.066 \\ \operatorname{DESN}(8) & 0.672 & -0.152 \\ \operatorname{DESN}(9) & 0.671 & 0.137 \\ \operatorname{DESN}(14) & 0.583 & 0.150 \\ \operatorname{DESN}(3) & -0.096 & 0.686\end{array}$




$\begin{array}{lrr}\operatorname{DESN}(17) & 0.291 & 0.593 \\ \operatorname{DESN}(4) & -0.132 & 0.569 \\ \operatorname{DESN}(12) & 0.183 & 0.472 \\ \operatorname{DESN}(16) & 0.380 & 0.450 \\ \operatorname{DESN}(5) & 0.052 & 0.364 \\ \operatorname{DESN}(2) & 0.249 & 0.261 \\ \operatorname{DESN}(11) & 0.382 & 0.207 \\ \operatorname{DESN}(15) & 0.260 & 0.145 \\ \operatorname{DESN}(1) & 0.277 & 0.096\end{array}$

VARIANCE EXPLAINED BY ROTATED EACTORS

2

$4.123 \quad 1.941$

PERCENT OF TOTAL VARIANCE EXPLAINED

1

2

$24.254 \quad 11.418$ 
ITERATIVE PRINCIPAL AXIS FACTOR ANALYSIS

$\begin{array}{cc}\text { ITERATION MAXIMUM CHANGE IN COMMUNALITIES } \\ 1 & 0.0083 \\ 2 & 0.1646 \\ 3 & 0.0458 \\ 4 & 0.0328 \\ 5 & 0.0225 \\ 6 & 0.0156 \\ 7 & 0.0109 \\ 8 & 0.0077 \\ 9 & 0.0054 \\ 10 & 0.0039 \\ 11 & 0.0028 \\ 12 & 0.0020 \\ 13 & 0.0014 \\ 14 & 0.0010 \\ 15 & 0.0007\end{array}$

FINAL COMMUNALITY ESTIMATES

$\begin{array}{lll}1 & 2 & 3 \\ 0.095 & 0.451 & 0.577\end{array}$

LATENT ROOTS (EIGENVALUES)

$\begin{array}{lllll}1 & 2 & 3 & 4 & 5 \\ 4.416 & 1.825 & 1.185 & 0.644 & 0.396 \\ 6 & 7 & 8 & 9 & 10 \\ 0.240 & 0.141 & 0.123 & 0.054 & -0.013 \\ 11 & 12 & 13 & 14 & 15 \\ -0.065 & -0.112 & -0.138 & -0.193 & -0.294 \\ 16 & 17 & & - & \end{array}$


$-0.371 \quad-0.413$

EACTOR PATTERN

\begin{tabular}{lllr} 
& 1 & 2 & \multicolumn{1}{l}{3} \\
& & & \\
$\operatorname{DESN}(10)$ & 0.770 & -0.135 & 0.029 \\
$\operatorname{DESN}(13)$ & 0.762 & -0.105 & 0.146 \\
$\operatorname{DESN}(6)$ & 0.711 & -0.116 & 0.009 \\
$\operatorname{DESN}(9)$ & 0.679 & -0.057 & -0.062 \\
$\operatorname{DESN}(8)$ & 0.657 & -0.447 & -0.537 \\
$\operatorname{DESN}(7)$ & 0.656 & -0.256 & 0.051 \\
$\operatorname{DESN}(14)$ & 0.603 & -0.035 & -0.192 \\
$\operatorname{DESN}(3)$ & 0.114 & 0.692 & -0.292 \\
$\operatorname{DESN}(4)$ & 0.044 & 0.627 & -0.427 \\
$\operatorname{DESN}(2)$ & 0.332 & 0.242 & 0.531 \\
$\operatorname{DESN}(11)$ & 0.438 & 0.114 & 0.381 \\
$\operatorname{DESN}(5)$ & 0.157 & 0.347 & 0.271 \\
$\operatorname{DESN}(15)$ & 0.293 & 0.073 & 0.226 \\
$\operatorname{DESN}(1)$ & 0.293 & 0.008 & -0.095 \\
$\operatorname{DESN}(16)$ & 0.492 & 0.315 & -0.070 \\
$\operatorname{DESN}(17)$ & 0.446 & 0.451 & -0.031 \\
$\operatorname{DESN}(12)$ & 0.311 & 0.376 & 0.021
\end{tabular}

VARIANCE EXPLAINED BY FACTORS

123
4.416
1.825
1.185

PERCENT OF TOTAL VARIANCE EXPLAINED

$\begin{array}{ccc}1 & 2 & 3 \\ 25.974 & 10.738 & 6.973\end{array}$

ROTATED FACTOR PATTERN

1

2

3

$\begin{array}{lrrr}\operatorname{DESN}(8) & 0.885 & -0.021 & -0.370 \\ \operatorname{DESN}(10) & 0.735 & 0.015 & 0.267 \\ \operatorname{DESN}(13) & 0.687 & -0.012 & 0.375 \\ \operatorname{DESN}(6) & 0.681 & 0.030 & 0.235\end{array}$




$\begin{array}{lrrr}\operatorname{DESN}(7) & 0.666 & -0.122 & 0.200 \\ \operatorname{DESN}(9) & 0.650 & 0.108 & 0.183 \\ \operatorname{DESN}(14) & 0.605 & 0.167 & 0.060 \\ \operatorname{DESN}(3) & -0.051 & 0.757 & 0.043 \\ \operatorname{DESN}(4) & -0.058 & 0.748 & -0.122 \\ \operatorname{DESN}(2) & 0.082 & 0.034 & 0.666 \\ \operatorname{DESN}(11) & 0.259 & 0.010 & 0.532 \\ \operatorname{DESN}(5) & -0.045 & 0.210 & 0.416 \\ \operatorname{DESN}(15) & 0.182 & 0.017 & 0.330 \\ \operatorname{DESN}(17) & 0.262 & 0.492 & 0.304 \\ \operatorname{DESN}(12) & 0.151 & 0.378 & 0.271 \\ \operatorname{DESN}(16) & 0.359 & 0.400 & 0.239 \\ \operatorname{DESN}(1) & 0.287 & 0.106 & 0.032\end{array}$

VARIANCE EXPLAINED BY ROTATED EACTORS

$\begin{array}{lll}1 & 2 & 3 \\ 3.908 & 1.788 & 1.730\end{array}$

PERCENT OF TOTAL VARIANCE EXPLAINED

123

$\begin{array}{lll}22.986 & 10.520 & 10.179\end{array}$ 
ITERATIVE PRINCIPAL AXIS FACTOR ANALYSIS

$\begin{array}{cc}\text { ITERATION MAXIMUM CHANGE IN COMMUNALITIES } \\ 1 & 0.8083 \\ 2 & 0.1560 \\ 3 & 0.0373 \\ 4 & 0.0260 \\ 5 & 0.0176 \\ 6 & 0.0120 \\ 7 & 0.0083 \\ 8 & 0.0057 \\ 9 & 0.0041 \\ 10 & 0.0031 \\ 11 & 0.0024 \\ 12 & 0.0019 \\ 13 & 0.0015 \\ 14 & 0.0011 \\ 15 & 0.0009\end{array}$

FINAL COMMUNALITY ESTIMATES

$\begin{array}{llll}1 & 2 & 3 & 4 \\ 0.093 & 0.492 & 0.704 & 0.539\end{array}$

LATENT ROOTS (EIGENVALUES)

$\begin{array}{lllll}1 & 2 & 3 & 4 & 5 \\ 4.468 & 1.897 & 1.199 & 0.760 & 0.440 \\ 6 & 7 & 8 & 9 & 10 \\ 0.278 & 0.204 & 0.172 & 0.071 & 0.014 \\ 11 & 12 & 13 & 14 & 15 \\ -0.003 & -0.051 & -0.078 & -0.171 & -0.236 \\ 16 & 17 & & -. & \end{array}$


FACTOR PAT:ERN

\begin{tabular}{lllrr} 
& 1 & \multicolumn{1}{l}{} & \multicolumn{1}{l}{4} \\
& & & & \\
$\operatorname{DESN}(10)$ & 0.792 & -0.163 & 0.026 & 0.338 \\
$\operatorname{DESN}(13)$ & 0.755 & -0.118 & 0.140 & 0.015 \\
$\operatorname{DESN}(6)$ & 0.711 & -0.122 & 0.006 & -0.163 \\
$\operatorname{DESN}(9)$ & 0.684 & -0.072 & -0.068 & 0.228 \\
$\operatorname{DESN}(7)$ & 0.653 & -0.262 & 0.048 & -0.127 \\
$\operatorname{DESN}(8)$ & 0.646 & -0.432 & -0.530 & -0.063 \\
$\operatorname{DESN}(14)$ & 0.608 & -0.039 & -0.191 & -0.242 \\
$\operatorname{DESN}(3)$ & 0.120 & 0.723 & -0.309 & 0.266 \\
$\operatorname{DESN}(4)$ & 0.047 & 0.604 & -0.400 & 0.106 \\
$\operatorname{DESN}(2)$ & 0.335 & 0.227 & 0.547 & 0.169 \\
$\operatorname{DESN}(17)$ & 0.469 & 0.500 & -0.027 & -0.397 \\
$\operatorname{DESN}(12)$ & 0.321 & 0.397 & 0.037 & -0.318 \\
$\operatorname{DESN}(16)$ & 0.499 & 0.310 & -0.074 & 0.246 \\
$\operatorname{DESN}(5)$ & 0.160 & 0.350 & 0.295 & -0.217 \\
$\operatorname{DESN}(11)$ & 0.436 & 0.101 & 0.380 & 0.084 \\
$\operatorname{DESN}(15)$ & 0.292 & 0.063 & 0.228 & 0.069 \\
$\operatorname{DESN}(1)$ & 0.291 & 0.005 & -0.094 & 0.005
\end{tabular}

VARIANCE EXPLAINED BY FACTORS

$\begin{array}{llll}1 & 2 & 3 & 4 \\ 4.468 & 1.897 & 1.199 & 0.760\end{array}$

PERCENT OF TOTAL VARIANCE EXPLAINED

$\begin{array}{llll}1 & 2 & 3 & 4 \\ 26.283 & 11.160 & 7.054 & 4.470\end{array}$

ROTATED EACTOR PATTERN

1234

$\begin{array}{lrrrr}\operatorname{DESN}(8) & 0.902 & -0.016 & -0.254 & -0.099 \\ \operatorname{DESN}(10) & 0.720 & 0.113 & 0.460 & -0.158 \\ \operatorname{DESN}(6) & 0.661 & -0.081 & 0.214 & 0.240 \\ \operatorname{DESN}(7) & 0.643 & -0.196 & 0.210 & 0.129 \\ \operatorname{DESN}(13) & 0.643 & -0.057 & 0.411 & 0.131\end{array}$




$\begin{array}{lrrrr}\operatorname{DESN}(9) & 0.633 & 0.164 & 0.314 & -0.062 \\ \operatorname{DESN}(14) & 0.616 & 0.028 & 0.000 & 0.293 \\ \operatorname{DESN}(3) & -0.049 & 0.820 & 0.059 & 0.160 \\ \operatorname{DESN}(4) & -0.032 & 0.695 & -0.133 & 0.191 \\ \operatorname{DESN}(2) & 0.008 & 0.021 & 0.685 & 0.149 \\ \operatorname{DESN}(11) & 0.203 & -0.018 & 0.537 & 0.150 \\ \operatorname{DESN}(17) & 0.254 & 0.263 & 0.114 & 0.694 \\ \operatorname{DESN}(12) & 0.136 & 0.174 & 0.113 & 0.549 \\ \operatorname{DESN}(5) & -0.083 & 0.040 & 0.280 & 0.442 \\ \operatorname{DESN}(15) & 0.146 & 0.003 & 0.343 & 0.084 \\ \operatorname{DESN}(16) & 0.340 & 0.436 & 0.313 & 0.082 \\ \operatorname{DESN}(1) & 0.283 & 0.086 & 0.051 & 0.057\end{array}$

VARIANCE EXPLAINED BY ROTATED EACTORS

$\begin{array}{llll}1 & 2 & 3 & 4 \\ 3.727 & 1.544 & 1.735 & 1.318\end{array}$

PERCENT OF TOTAL VARIANCE EXPLAINED

$\begin{array}{llll}1 & 2 & 3 & 4 \\ 21.926 & 9.082 & 10.205 & 7.755\end{array}$




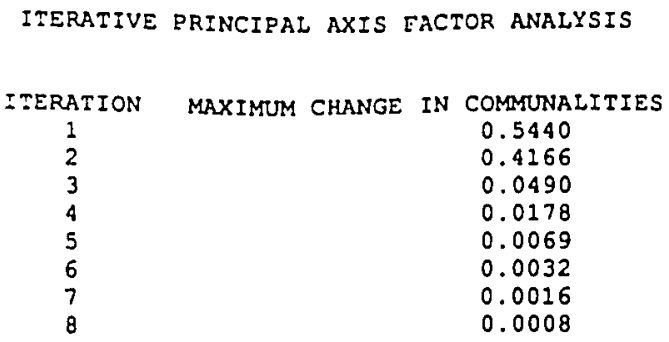

FINAL COMMUNALITY ESTIMATES

$\begin{array}{ll}1 & 2 \\ 0.613 & 0.637\end{array}$

LATENT ROOTS (EIGENVALUES)

1

2

3

4

5

4.704

1.765

1.061

0.747

0.559

6

7

8

9

10

0.273

0.187

0.101

0.049

$-0.137$

11

12

13

14

15

$-0.225$

$-0.309$

$-0.356$

$-0.401$

$-0.445$

16

17

$-0.531$

$-0.573$

FACTOR PATTERN

1

2 


$\begin{array}{llr}\operatorname{cosT}(24) & 0.697 & -0.131 \\ \operatorname{cosT}(25) & 0.667 & 0.088 \\ \operatorname{CosT}(21) & 0.665 & 0.100 \\ \operatorname{cosT}(31) & 0.649 & 0.112 \\ \operatorname{cosT}(26) & 0.625 & -0.032 \\ \operatorname{cosT}(28) & 0.619 & -0.013 \\ \operatorname{cosT}(23) & 0.599 & 0.426 \\ \operatorname{cosT}(33) & 0.548 & 0.155 \\ \operatorname{cosT}(18) & 0.409 & -0.667 \\ \operatorname{cosT}(19) & 0.472 & -0.643 \\ \operatorname{cosT}(32) & 0.425 & 0.549 \\ \operatorname{cosT}(29) & 0.266 & -0.549 \\ \operatorname{cosT}(22) & 0.294 & 0.141 \\ \operatorname{cosT}(27) & 0.384 & 0.112 \\ \operatorname{cosT}(34) & 0.414 & -0.105 \\ \operatorname{cosT}(20) & 0.492 & 0.077 \\ \operatorname{cosT}(30) & 0.434 & -0.019\end{array}$

VARIANCE EXPLAINED BY FACTORS

$\begin{array}{ll}1 & 2 \\ 4.704 & 1.765\end{array}$

PERCENT OF TOTAL VARIANCE EXPLAINED

1

$27.668 \quad 10.382$

ROTATED FACTOR PATTERN

1

2

$\begin{array}{llr}\operatorname{cosT}(23) & 0.721 & -0.142 \\ \operatorname{cosT}(21) & 0.647 & 0.182 \\ \operatorname{cosT}(25) & 0.644 & 0.194 \\ \operatorname{cosT}(31) & 0.637 & 0.164 \\ \operatorname{cosT}(32) & 0.613 & -0.326 \\ \operatorname{cosT}(24) & 0.581 & 0.405 \\ \operatorname{cosT}(33) & 0.564 & 0.084 \\ \operatorname{cosT}(28) & 0.559 & 0.266 \\ \operatorname{cosT}(26) & 0.556 & 0.286 \\ \operatorname{cosT}(19) & 0.167 & 0.780 \\ \operatorname{cosT}(18) & 0.099 & 0.776 \\ \operatorname{cosT}(29) & 0.017 & 0.610 \\ \operatorname{cosT}(34) & 0.334 & 0.266\end{array}$




$\begin{array}{llr}\operatorname{cosT}(30) & 0.388 & 0.195 \\ \operatorname{cosT}(20) & 0.480 & 0.132 \\ \operatorname{cosT}(27) & 0.396 & 0.056 \\ \operatorname{cosT}(22) & 0.326 & -0.008\end{array}$

VARIANCE EXPLAINED BY ROTATED FACTORS

$\begin{array}{ll}1 & 2 \\ 4.200 & 2.260\end{array}$

PERCENT OF TOTAL VARIANCE EXPLAINED

12

24.753

13.297 
ITERATIVE PRINCIPAL AXIS EACTOR ANALYSIS

$\begin{array}{cc}\text { :TERATION MAXIMUM CHANGE IN COMMUNALITIES } \\ 1 & 0.5440 \\ 2 & 0.3443 \\ 3 & 0.0637 \\ 4 & 0.0349 \\ 5 & 0.0236 \\ 6 & 0.0161 \\ 7 & 0.0109 \\ 8 & 0.0075 \\ 9 & 0.0052 \\ 10 & 0.0036 \\ 11 & 0.0025 \\ 12 & 0.0017 \\ 13 & 0.0012 \\ 14 & 0.0008\end{array}$

EINAL COMMNALITY ESTIMATES

$\begin{array}{lll}1 & 2 & 3 \\ 0.611 & 0.621 & 0.646\end{array}$

LATENT ROOTS (EIGENVALUES)

$\begin{array}{lllll}1 & 2 & 3 & 4 & 5 \\ 4.790 & 1.838 & 1.287 & 0.794 & 0.652 \\ 0.318 & 0.221 & 0.139 & 0.091 & -0.008 \\ 11 & 7 & 8 & 9 & 10 \\ -0.145 & -0.176 & -0.264 & -0.310 & -0.351 \\ 16 & 17 & 13 & 14 & \\ -0.437 & -0.522 & & & \end{array}$


EACTOR PATTERN

\begin{tabular}{lrrr} 
& 1 & \multicolumn{1}{l}{} & \multicolumn{1}{l}{3} \\
& & & \\
$\operatorname{cosT}(24)$ & 0.700 & -0.140 & 0.268 \\
$\operatorname{cosT}(21)$ & 0.693 & 0.066 & -0.428 \\
$\operatorname{cosT}(25)$ & 0.663 & 0.063 & -0.127 \\
$\operatorname{cosT}(31)$ & 0.645 & 0.104 & 0.154 \\
$\operatorname{cosT}(26)$ & 0.619 & -0.060 & -0.129 \\
$\operatorname{cosT}(28)$ & 0.612 & -0.017 & 0.147 \\
$\operatorname{cosT}(23)$ & 0.602 & 0.398 & -0.228 \\
$\operatorname{cosT}(33)$ & 0.554 & 0.159 & 0.233 \\
$\operatorname{cosT}(20)$ & 0.533 & 0.045 & -0.600 \\
$\operatorname{cosT}(32)$ & 0.458 & 0.666 & 0.429 \\
$\operatorname{cosT}(18)$ & 0.399 & -0.664 & 0.104 \\
$\operatorname{cosT}(19)$ & 0.460 & -0.629 & 0.116 \\
$\operatorname{cosT}(29)$ & 0.258 & -0.534 & 0.064 \\
$\operatorname{cosT}(30)$ & 0.450 & 0.000 & 0.459 \\
$\operatorname{cosT}(34)$ & 0.413 & -0.124 & -0.187 \\
$\operatorname{cosT}(27)$ & 0.383 & 0.096 & -0.144 \\
$\operatorname{cosT}(22)$ & 0.294 & 0.139 & 0.098
\end{tabular}

VARIANCE EXPLAINED BY FACTORS

$\begin{array}{lll}1 & 2 & 3 \\ 4.790 & 1.838 & 1.287\end{array}$

PERCENT OF TOTAL VARIANCE EXPLAINED

123

$\begin{array}{lll}28.177 & 10.811 & 7.570\end{array}$

ROTATED EACTOR PATTERN

\begin{tabular}{lrrr} 
& 1 & \multicolumn{1}{l}{2} & \multicolumn{1}{l}{3} \\
$\operatorname{cosT}(32)$ & 0.827 & -0.380 & 0.093 \\
$\operatorname{cosT}(30)$ & 0.598 & 0.234 & -0.028 \\
$\operatorname{cosT}(24)$ & 0.579 & 0.423 & 0.258 \\
$\operatorname{cosT}(33)$ & 0.572 & 0.089 & 0.227 \\
$\operatorname{cosT}(31)$ & 0.557 & 0.161 & 0.339 \\
$\operatorname{cosT}(18)$ & 0.083 & 0.771 & 0.100 \\
$\operatorname{cosT}(19)$ & 0.143 & 0.763 & 0.138 \\
$\operatorname{cosT}(29)$ & 0.014 & 0.594 & 0.053 \\
$\operatorname{cosT}(20)$ & -0.043 & 0.057 & 0.800
\end{tabular}




$\begin{array}{lrrr}\cos T(21) & 0.183 & 0.122 & 0.787 \\ \operatorname{cosT}(23) & 0.381 & -0.184 & 0.628 \\ \operatorname{cosT}(25) & 0.364 & 0.161 & 0.548 \\ \operatorname{cosT}(26) & 0.290 & 0.258 & 0.502 \\ \operatorname{cosT}(34) & 0.095 & 0.234 & 0.397 \\ \operatorname{cosT}(27) & 0.185 & 0.027 & 0.376 \\ \operatorname{cosT}(28) & 0.487 & 0.259 & 0.305 \\ \operatorname{cosT}(22) & 0.306 & -0.006 & 0.147\end{array}$

VARIANCE EXPLAINED BY ROTATED EACTORS

$\begin{array}{lll}2 & 2 & 3 \\ 2.813 & 2.208 & 2.894\end{array}$

PERCENT OF TOTAL VARIANCE EXPLAINED

$\begin{array}{ccc}1 & 2 & 3 \\ 16.548 & 12.987 & 17.022\end{array}$


ITERATIVE PRINCIPAL AXIS FACTOR ANALYSIS

$\begin{array}{cc}\text { ITERATION } & \text { MAXIMUM CHANGE IN COMMUNALITIES } \\ 1 & 0.5440 \\ 2 & 0.2517 \\ 3 & 0.0425 \\ 4 & 0.0203 \\ 5 & 0.0133 \\ 6 & 0.0087 \\ 7 & 0.0057 \\ 8 & 0.0046 \\ 9 & 0.0036 \\ 10 & 0.0029 \\ 11 & 0.0023 \\ 12 & 0.0018 \\ 13 & 0.0014 \\ 14 & 0.0011 \\ 15 & 0.0008\end{array}$

FINAL COMMUNALITY ESTIMATES

$\begin{array}{llll}1 & 2 & 3 & 4 \\ 0.768 & 0.581 & 0.587 & 0.646\end{array}$

LATENT ROOTS (EIGENVALUES)

$\begin{array}{lllll}1 & 2 & 3 & 4 & 5 \\ 4.839 & 1.892 & 1.321 & 0.993 & 0.686 \\ 6 & 7 & 8 & 9 & 10 \\ 0.397 & 0.276 & 0.224 & 0.107 & 0.012 \\ 11 & 12 & 13 & 14 & 15 \\ -0.086 & -0.126 & -0.167 & -0.264 & -0.274 \\ 16 & 17 & & & \\ -0.381 & -0.404 & & & \end{array}$


FACTOR PATTERN

\begin{tabular}{|c|c|c|c|c|}
\hline & 1 & 2 & 3 & 4 \\
\hline $\operatorname{cost}(24)$ & 0.717 & -0.135 & 0.321 & 0.299 \\
\hline $\operatorname{cosT}(21)$ & 0.685 & 0.085 & -0.392 & 0.129 \\
\hline $\operatorname{cost}(25)$ & 0.659 & 0.078 & -0.132 & 0.081 \\
\hline $\cos 2(31)$ & 0.644 & 0.109 & 0.150 & 0.112 \\
\hline $\operatorname{cosT}(26)$ & 0.616 & -0.044 & -0.147 & 0.056 \\
\hline $\operatorname{cosT}(28)$ & 0.608 & -0.008 & 0.112 & 0.030 \\
\hline $\operatorname{cost}(23)$ & 0.600 & 0.415 & -0.239 & -0.117 \\
\hline $\cos 5(33)$ & 0.566 & 0.168 & 0.252 & -0.307 \\
\hline $\operatorname{cosT}(20)$ & 0.522 & 0.061 & -0.557 & -0.008 \\
\hline $\operatorname{cosT}(1 \varepsilon)$ & 0.414 & -0.703 & 0.119 & 0.295 \\
\hline $\operatorname{cosT}(32)$ & 0.446 & 0.632 & 0.407 & -0.068 \\
\hline $\operatorname{cosT}(19)$ & 0.458 & -0.603 & 0.082 & -0.037 \\
\hline $\operatorname{cosT}(29)$ & 0.271 & -0.575 & 0.020 & -0.343 \\
\hline $\operatorname{cosT}(34)$ & 0.450 & -0.147 & -0.306 & -0.563 \\
\hline $\operatorname{cosT}(27)$ & 0.386 & 0.110 & -0.150 & 0.321 \\
\hline $\cos T(30)$ & 0.463 & -0.008 & 0.489 & -0.303 \\
\hline $\cos T(22)$ & 0.294 & 0.142 & 0.132 & 0.185 \\
\hline
\end{tabular}

VARIANCE EXPLAINED BY FACTORS

$\begin{array}{llll}1 & 2 & 3 & 4 \\ 4.839 & 1.892 & 1.321 & 0.993\end{array}$

PERCENT OF TOTAL VARIANCE EXPLAINED

$\begin{array}{llll}1 & 2 & 3 & 4 \\ 28.465 & 11.129 & 7.771 & 5.842\end{array}$

ROTATED EACTOR PATTERN

2

3

4

$\begin{array}{lrrrr}\operatorname{cosT}(32) & 0.782 & -0.319 & 0.182 & -0.148 \\ \operatorname{cosT}(30) & 0.677 & 0.223 & -0.055 & 0.183 \\ \operatorname{cosT}(33) & 0.638 & 0.055 & 0.199 & 0.238 \\ \operatorname{cosT}(24) & 0.518 & 0.512 & 0.364 & -0.249 \\ \operatorname{cosT}(18) & 0.001 & 0.858 & 0.152 & -0.096 \\ \operatorname{cosT}(19) & 0.117 & 0.712 & 0.137 & 0.202 \\ \operatorname{cosT}(29) & 0.050 & 0.546 & -0.034 & 0.469\end{array}$




$\begin{array}{lrrrr}\operatorname{cosT}(21) & 0.128 & 0.122 & 0.780 & 0.083 \\ \operatorname{cosT}(20) & -0.056 & 0.021 & 0.724 & 0.244 \\ \operatorname{cosT}(23) & 0.362 & -0.217 & 0.629 & 0.174 \\ \operatorname{cosT}(25) & 0.301 & 0.164 & 0.587 & 0.041 \\ \operatorname{cosT}(26) & 0.228 & 0.248 & 0.533 & 0.089 \\ \operatorname{cosT}(34) & 0.135 & 0.122 & 0.323 & 0.704 \\ \operatorname{cosT}(27) & 0.083 & 0.077 & 0.477 & -0.216 \\ \operatorname{cosT}(22) & 0.268 & 0.048 & 0.208 & -0.202 \\ \operatorname{cosT}(31) & 0.490 & 0.196 & 0.419 & -0.087 \\ \operatorname{cosT}(28) & 0.421 & 0.263 & 0.369 & 0.021\end{array}$

VARIANCE EXPLAINED BY ROTATED FACTORS

2

4

$\begin{array}{llll}2.567 & 2.240 & 3.096 & 1.142\end{array}$

PERCENT OF TOTAL VARIANCE EXPLAINED

$\begin{array}{cccc}1 & 2 & 3 & 4 \\ 15.102 & 13.177 & 18.214 & 6.715\end{array}$


ITERATIVE PRINCIPAL AXIS FACTOR ANALYSIS

$\begin{array}{cc}\text { ITERATION MAXIMUM CHANGE IN COMMUNALITIES } \\ 1 & 0.5107 \\ 2 & 0.4814 \\ 3 & 0.0914 \\ 4 & 0.0352 \\ 5 & 0.0148 \\ 6 & 0.0065 \\ 7 & 0.0029 \\ 8 & 0.0013 \\ 9 & 0.0006\end{array}$

EINAL COMMUNALITY ESTIMATES

$\begin{array}{ll}1 & 2 \\ 0.436 & 0.509\end{array}$

LATENT ROOTS (EIGENVALUES)

$\begin{array}{lllll}1 & 2 & 3 & 4 & 5 \\ 5.987 & 1.511 & 0.821 & 0.569 & 0.508 \\ 6 & 7 & 8 & 9 & 10 \\ 0.364 & 0.236 & 0.099 & 0.016 & -0.073 \\ 11 & 12 & 13 & 14 & 15 \\ -0.203 & -0.260 & -0.277 & -0.366 & -0.396 \\ 16 & 17 & & & \\ -0.503 & -0.536 & & & \end{array}$

EACTOR PATTERN

12

TIME (44)

0.774

0.199 


$\begin{array}{llr}\operatorname{TME}(48) & 0.737 & 0.389 \\ \operatorname{IIME}(42) & 0.730 & 0.304 \\ \operatorname{TIME}(50) & 0.717 & 0.201 \\ \operatorname{IIME}(39) & 0.701 & -0.109 \\ \operatorname{TIME}(47) & 0.656 & 0.038 \\ \operatorname{IIME}(36) & 0.613 & -0.365 \\ \operatorname{TIME}(43) & 0.601 & 0.096 \\ \operatorname{TIME}(37) & 0.579 & -0.375 \\ \operatorname{TIME}(51) & 0.562 & 0.107 \\ \operatorname{TIME}(40) & 0.553 & -0.343 \\ \operatorname{TIME}(49) & 0.442 & 0.542 \\ \operatorname{TIME}(35) & 0.480 & -0.454 \\ \operatorname{TIME}(38) & 0.475 & -0.424 \\ \operatorname{TIME}(41) & 0.455 & -0.198 \\ \operatorname{TIME}(46) & 0.304 & 0.197 \\ \operatorname{TIME}(45) & 0.480 & -0.067\end{array}$

VARIANCE EXPLAINED BY FACTORS

$\begin{array}{ll}1 & 2 \\ 5.987 & 1.511\end{array}$

PERCENT OF TOTAL VARIANCE EXFLAINED

$\begin{array}{cc}1 & 2 \\ 35.219 & 8.891\end{array}$

ROTATED EACTOR PATTERN

1

2

$\begin{array}{lrr}\operatorname{TIME}(48) & 0.809 & 0.198 \\ \operatorname{TIME}(42) & 0.748 & 0.258 \\ \operatorname{TIME}(44) & 0.711 & 0.365 \\ \operatorname{TIME}(49) & 0.690 & -0.112 \\ \operatorname{TIME}(50) & 0.670 & 0.326 \\ \operatorname{TIMEE}(47) & 0.516 & 0.407 \\ \operatorname{TIMEE}(43) & 0.513 & 0.327 \\ \operatorname{TIME}(36) & 0.216 & 0.680 \\ \operatorname{TIME}(37) & 0.184 & 0.665 \\ \operatorname{TIME}(35) & 0.057 & 0.658 \\ \operatorname{TIME}(38) & 0.074 & 0.633 \\ \operatorname{TIME}(40) & 0.186 & 0.624 \\ \operatorname{TIME}(39) & 0.452 & 0.547 \\ \operatorname{TIME}(41) & 0.209 & 0.450 \\ \operatorname{TIME}(45) & 0.314 & 0.369 \\ \operatorname{TIME}(51) & 0.491 & 0.293 \\ \operatorname{TIME}(46) & 0.358 & 0.055\end{array}$

VARIANCE EXPLAINED BY ROTATED FACTORS 
1

2

$4.015 \quad 3.483$

PERCENT OF TOTAL VARIANCE EXPLAINED

1

23.620
2

20.490 
ITERATIVE PRINCIPAL AXIS FACTOR ANALYSIS

$\begin{array}{cc}\text { ITERATION } & \text { MAXIMUM CHANGE IN COMMUNAIITIES } \\ 1 & 0.5107 \\ 2 & 0.4719 \\ 3 & 0.0715 \\ 4 & 0.0201 \\ 5 & 0.0123 \\ 6 & 0.0081 \\ 7 & 0.0054 \\ 8 & 0.0036 \\ 9 & 0.0024 \\ 10 & 0.0016 \\ 11 & 0.0011 \\ 12 & 0.0007\end{array}$

FINAL COMMUNALITY ESTIMATES

$\begin{array}{lll}1 & 2 & 3 \\ 0.424 & 0.682 & 0.633\end{array}$

LATENT ROOTS (EIGENVALUES)

$\begin{array}{lllll}1 & 2 & 3 & 4 & 5 \\ 6.063 & 1.587 & 0.956 & 0.600 & 0.559 \\ 6 & 7 & 8 & 9 & 10 \\ 0.392 & 0.297 & 0.148 & 0.089 & -0.007 \\ 11 & 12 & 13 & 14 & 15 \\ -0.086 & -0.149 & -0.252 & -0.318 & -0.333 \\ 16 & 17 & & & \\ -0.420 & -0.519 & & & \end{array}$

FACTOR PATTERN

1

2

3 


$\begin{array}{lrrr}\operatorname{TIME}(44) & 0.793 & 0.228 & 0.387 \\ \operatorname{TIME}(48) & 0.745 & 0.405 & -0.285 \\ \operatorname{TIME}(42) & 0.727 & 0.306 & 0.140 \\ \operatorname{TIME}(50) & 0.725 & 0.209 & -0.300 \\ \operatorname{TIME}(39) & 0.695 & -0.098 & -0.024 \\ \operatorname{TIME}(47) & 0.653 & 0.047 & 0.124 \\ \operatorname{TIME}(36) & 0.627 & -0.385 & 0.374 \\ \operatorname{TIME}(43) & 0.599 & 0.100 & 0.142 \\ \operatorname{TIME}(37) & 0.592 & -0.423 & -0.322 \\ \operatorname{TIME}(51) & 0.568 & 0.114 & -0.307 \\ \operatorname{TIME}(40) & 0.548 & -0.325 & -0.011 \\ \operatorname{TIME}(49) & 0.438 & 0.521 & -0.094 \\ \operatorname{TIME}(38) & 0.490 & -0.489 & -0.369 \\ \operatorname{TIME}(45) & 0.484 & -0.067 & 0.280 \\ \operatorname{TIME}(35) & 0.476 & -0.429 & 0.113 \\ \operatorname{TIME}(46) & 0.302 & 0.186 & 0.054 \\ \operatorname{TIME}(41) & 0.452 & -0.181 & 0.054\end{array}$

VARIANCE EXPLAINED BY FACTORS

$\begin{array}{lll}1 & 2 & 3 \\ 6.063 & 1.587 & 0.956\end{array}$

PERCENT OF TOTAL VARIANCE EXPLAINED

123

$\begin{array}{lll}35.662 & 9.333 & 5.625\end{array}$

ROTATED FACTOR PATTERN

123

$\begin{array}{lrrr}\operatorname{IIME}(48) & 0.847 & 0.261 & 0.117 \\ \operatorname{TIME}(50) & 0.699 & 0.390 & 0.139 \\ \operatorname{IIME}(49) & 0.680 & -0.074 & 0.061 \\ \operatorname{IIME}(42) & 0.651 & 0.079 & 0.461 \\ \operatorname{IIME}(44) & 0.571 & 0.024 & 0.710 \\ \operatorname{IIME}(51) & 0.531 & 0.379 & 0.064 \\ \operatorname{IIME}(38) & 0.067 & 0.774 & 0.110 \\ \operatorname{TIME}(37) & 0.168 & 0.754 & 0.191 \\ \operatorname{IIME}(36) & 0.029 & 0.354 & 0.745 \\ \operatorname{IIME}(45) & 0.190 & 0.126 & 0.515 \\ \operatorname{IIME}(47) & 0.423 & 0.222 & 0.466 \\ \operatorname{TIME}(35) & -0.029 & 0.456 & 0.464 \\ \operatorname{IIME}(43) & 0.420 & 0.151 & 0.435 \\ \operatorname{IIME}(39) & 0.386 & 0.422 & 0.408 \\ \operatorname{TIME}(40) & 0.125 & 0.493 & 0.385 \\ \operatorname{TIME}(41) & 0.148 & 0.313 & 0.346 \\ \operatorname{TIME}(46) & 0.313 & -0.004 & 0.175\end{array}$


VARIANCE EXPLAINED BY ROTATED FACTORS

$\begin{array}{lll}1 & 2 & 3 \\ 3.410 & 2.483 & 2.713\end{array}$

PERCENT OF TOTAL VARIANCE EXPLAINED

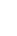

2

3

20.056

14.604

15.961 
ITERATIVE PRINCIPAL AXIS FACTOR ANALYSIS

$\begin{array}{cc}\text { ITERATION MAXIMUM CHANGE IN COMMUNALITIES } \\ 1 & 0.5107 \\ 2 & 0.2693 \\ 3 & 0.1568 \\ 4 & 0.0668 \\ 5 & 0.0388 \\ 6 & 0.0388 \\ 7 & 0.0383 \\ 8 & 0.0373 \\ 9 & 0.0358 \\ 10 & 0.0338 \\ 11 & 0.0316 \\ 12 & 0.0293 \\ 13 & 0.0096 \\ 14 & 0.0072 \\ 15 & 0.0053 \\ 16 & 0.0039 \\ 17 & 0.0028 \\ 18 & 0.0020 \\ 19 & 0.0015 \\ 20 & 0.0011 \\ 21 & 0.0008\end{array}$

FINAL COMMUNALITY ESTIMATES

$\begin{array}{llll}1 & 2 & 3 & 4 \\ 0.529 & 0.659 & 0.665 & 0.615\end{array}$

LATENT ROOTS (EIGENVALUES)

$\begin{array}{lllll}1 & 2 & 3 & 4 & 5 \\ 6.120 & 1.625 & 1.014 & 0.866 & 0.600 \\ 6 & 7 & 8 & 9 & 10 \\ 0.405 & 0.334 & 0.187 & 0.104 & 0.037 \\ 11 & 12 & 13 & 14 & 15 \\ -0.057 & -0.110 & -0.188 & -0.221 & -0.307\end{array}$


EACTOR PATTERN

1

$\operatorname{TIME}(44)$
$\operatorname{TIME}(48)$
$\operatorname{TIME}(42)$
$\operatorname{TIME}(50)$
$\operatorname{TIME}(39)$
$\operatorname{TIME}(43)$
$\operatorname{TIME}(47)$
$\operatorname{TIME}(36)$
$\operatorname{TIME}(37)$
$\operatorname{TIME}(51)$
$\operatorname{TIME}(40)$
$\operatorname{TIME}(49)$
$\operatorname{TIME}(45)$
$\operatorname{TIME}(35)$
$\operatorname{TIME}(38)$
$\operatorname{TIME}(46)$
$\operatorname{TIME}(41)$

0.785
0.745
0.726
0.722
0.700
0.653
0.651
0.622
0.592
0.564
0.550
0.439
0.485
0.480
0.486
0.304
0.449

2

0.219
0.400
0.306
0.205
-0.115
0.162
0.040
-0.374
-0.425
0.105
-0.323
0.524
-0.077
-0.466
-0.487
0.192
-0.182

3

0.291

$-0.355$

0.160

$-0.232$

$-0.147$

0.524

0.043

0.315

$-0.228$

$-0.292$

0.074

$-0.209$

0.150

$-0.003$

$-0.314$

0.103

0.036
4

$$
\begin{array}{r}
0.210 \\
0.031 \\
-0.022 \\
-0.206 \\
0.228 \\
-0.523 \\
0.162 \\
0.181 \\
-0.287 \\
-0.093 \\
-0.167 \\
0.153 \\
0.332 \\
0.286 \\
-0.209 \\
-0.073 \\
0.051
\end{array}
$$

VARIANCE EXPLAINED BY FACTORS
1

6.120
2

1.625
3

1.014
4

0.866

PERCENT OE TOTAL VARIANCE EXPLAINED

1

36.001

ROTATED EACYOR PATTERN
9.559

\section{2}

2

0.216

$-0.118$

0.389

0.075

0.354

0.765
3

5.965

TIME (49)

IIME (42)

TIME (S)

TIME (37)

0.864
0.712
0.639
0.538
0.524
0.144

0.141

0.080

0.298

0.491

0.106

0.138

4

5.095

4

0.169

0.089

0.107

0.333

0.110

0.203 


$\begin{array}{lrrrr}\operatorname{TIME}(38) & 0.093 & 0.755 & -0.022 & 0.189 \\ \operatorname{TIME}(43) & 0.169 & 0.218 & 0.952 & 0.231 \\ \operatorname{TIME}(36) & -0.015 & 0.295 & 0.276 & 0.704 \\ \operatorname{TIME}(35) & 0.010 & 0.373 & -0.081 & 0.619 \\ \operatorname{TIME}(44) & 0.478 & -0.009 & 0.456 & 0.598 \\ \operatorname{TIME}(45) & 0.195 & 0.044 & 0.096 & 0.570 \\ \operatorname{TIME}(39) & 0.427 & 0.338 & 0.028 & 0.529 \\ \operatorname{TIME}(47) & 0.399 & 0.171 & 0.213 & 0.468 \\ \operatorname{TIME}(41) & 0.130 & 0.276 & 0.133 & 0.358 \\ \operatorname{TIME}(40) & 0.053 & 0.497 & 0.286 & 0.329 \\ \operatorname{TIME}(46) & 0.241 & 0.007 & 0.282 & 0.086\end{array}$

VARIANCE EXPLAINED BY ROTATED FACTORS

1

2.969

2.240

1.818

2.569

PERCENT OF TOTAL VARIANCE EXPLAINED

1

17.467

13.178

10.696 
ITERATIVE PRINCIPAL AXIS FACTOR ANALYSIS

$\begin{array}{cc}\text { ITERATION MAXIMUM CHANGE IN COMMUNALITIES } \\ 1 & 0.6408 \\ 2 & 0.3139 \\ 3 & 0.0343 \\ 4 & 0.0185 \\ 5 & 0.0149 \\ 6 & 0.0127 \\ 7 & 0.0111 \\ 8 & 0.0099 \\ 9 & 0.0089 \\ 10 & 0.0081 \\ 11 & 0.0074 \\ 12 & 0.0067 \\ 13 & 0.0061 \\ 14 & 0.0056 \\ 15 & 0.0051 \\ 16 & 0.0047 \\ 17 & 0.0026 \\ 18 & 0.0018 \\ 19 & 0.0011 \\ 20 & 0.0006\end{array}$

FINAL COMMUNALITY ESTIMATES

$\begin{array}{ll}1 & 2 \\ 0.423 & 0.102\end{array}$

LATENT ROOTS (EIGENVALUES)

$\begin{array}{lllll}1 & 2 & 3 & 4 & 5 \\ 5.796 & 1.557 & 0.717 & 0.650 & 0.409 \\ 6 & 7 & 8 & 9 & 10 \\ 0.260 & 0.225 & 0.050 & 0.012 & -0.041 \\ 11 & 12 & 13 & 14 & 15 \\ -0.124 & -0.205 & -0.267 & -0.367 & -0.388 \\ 16 & 17 & & & \end{array}$


$-0.424 \quad-0.511$

FACTOR PATTERN

1

2

\begin{tabular}{|c|c|c|}
\hline $\operatorname{COMM}(64)$ & 0.805 & 0.138 \\
\hline COMM (59) & 0.703 & 0.183 \\
\hline $\operatorname{COMM}(61)$ & 0.682 & 0.146 \\
\hline СОMM (58) & 0.675 & 0.220 \\
\hline $\operatorname{COMM}(67)$ & 0.660 & -0.039 \\
\hline COMM (52) & 0.641 & 0.107 \\
\hline COMM $(65)$ & 0.631 & -0.072 \\
\hline СОМM $(60)$ & 0.595 & 0.081 \\
\hline $\operatorname{COMM}(56)$ & 0.574 & 0.226 \\
\hline $\operatorname{COMM}(68)$ & 0.555 & -0.053 \\
\hline $\operatorname{COMM}(62)$ & 0.545 & 0.259 \\
\hline $\operatorname{COMM}(63)$ & 0.528 & 0.080 \\
\hline $\operatorname{COMM}(54)$ & 0.527 & -0.687 \\
\hline $\operatorname{COMM}(55)$ & 0.451 & -0.892 \\
\hline $\operatorname{COMM}(53)$ & 0.309 & -0.083 \\
\hline $\operatorname{COMM}(66)$ & 0.407 & -0.067 \\
\hline $\operatorname{COMM}(57)$ & 0.418 & 0.006 \\
\hline
\end{tabular}

VARIANCE EXPLAINED BY FACTORS

$\begin{array}{ll}1 & 2 \\ 5.796 & 1.557\end{array}$

PERCENT OF TOTAL VARIANCE EXPLAINED

1

$34.095 \quad 9.161$

ROTATED FACTOR PATTERN

1

2

$\begin{array}{llr}\operatorname{COMM}(54) & 0.787 & 0.220 \\ \operatorname{COMM}(59) & 0.714 & 0.135 \\ \operatorname{COMM}(58) & 0.705 & 0.090 \\ \operatorname{COMM}(61) & 0.679 & 0.160 \\ \operatorname{COMM}(52) & 0.626 & 0.177 \\ \operatorname{COMM}(56) & 0.616 & 0.041 \\ \operatorname{COMM}(62) & 0.604 & -0.001 \\ \operatorname{COMM}(67) & 0.580 & 0.318 \\ \operatorname{COMM}(60) & 0.573 & 0.181 \\ \operatorname{COMM}(65) & 0.540 & 0.335\end{array}$




$\begin{array}{lll}\text { COMM (63) } & 0.511 & 0.153 \\ \text { COMM (55) } & 0.027 & 1.000 \\ \text { COMM (54) } & 0.183 & 0.846 \\ \operatorname{COMM}(68) & 0.480 & 0.285 \\ \operatorname{COMM}(66) & 0.340 & 0.235 \\ \operatorname{COMM}(53) & 0.244 & 0.207 \\ \operatorname{COMM}(57) & 0.380 & 0.173\end{array}$

VAREANCE EXPLAINED BY ROTATED EACTORS

1

2

$5.022 \quad 2.326$

PERCENT OF TOTAL VARIANCE EXPLAINED

12

$29.543 \quad 13.683$ 
ITERATIVE PRINCIPAL AXIS EACTOR ANAIYSIS

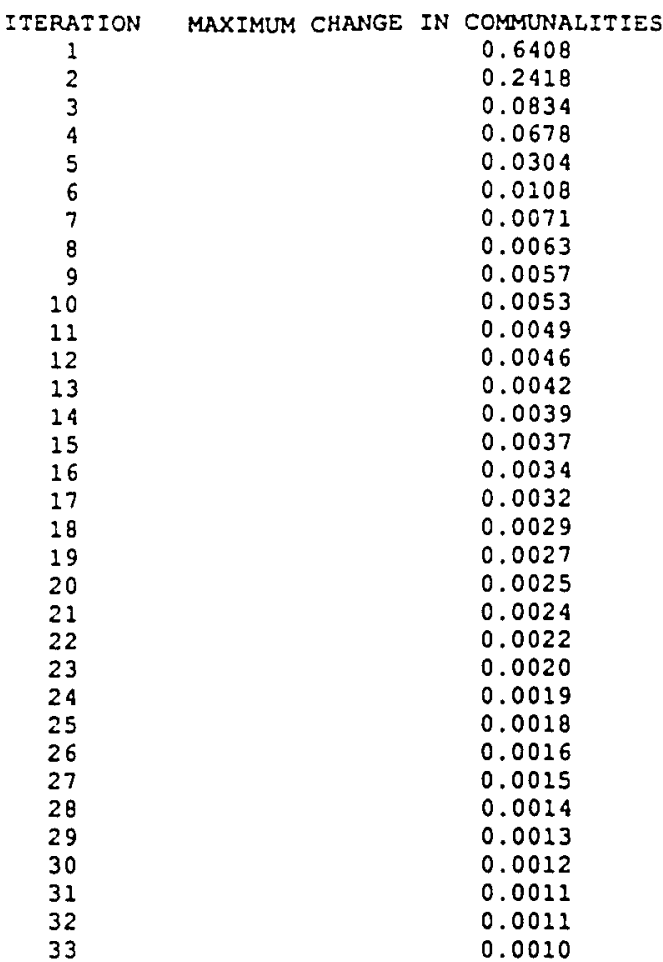

EINAL COMMUNALITY ESTIMATES

1

2
0.453
0.110
0.777

LATENT ROOTS (EIGENVALUES)

2

3

4

5.846

1.566

0.908

0.668

0.453

6 


$\begin{array}{lllll}0.297 & 0.281 & 0.087 & 0.239 & 0.025 \\ 11 & 12 & 13 & 24 & 15 \\ -0.066 & -0.139 & -0.192 & -0.231 & -0.357 \\ 16 & 17 & & & \\ -0.382 & -0.483 & & \end{array}$

EACTOR PATTERN

\begin{tabular}{|c|c|c|c|}
\hline $\operatorname{COMM}(64)$ & 0.815 & 0.151 & 0.276 \\
\hline $\operatorname{CoMM}(59)$ & 0.704 & 0.183 & -0.167 \\
\hline $\operatorname{COMM}(61)$ & 0.679 & 0.147 & 0.030 \\
\hline $\operatorname{COMM}(67)$ & 0.675 & -0.049 & -0.355 \\
\hline $\operatorname{COMM}(58)$ & 0.672 & 0.218 & 0.010 \\
\hline $\operatorname{COMM}(52)$ & 0.642 & 0.111 & 0.170 \\
\hline $\operatorname{ComM}(65)$ & 0.632 & -0.075 & -0.149 \\
\hline COMM $(60)$ & 0.595 & 0.088 & 0.184 \\
\hline СОMM (56) & 0.572 & 0.225 & 0.015 \\
\hline $\operatorname{COMM}(68)$ & 0.556 & -0.054 & -0.154 \\
\hline СОМM (62) & 0.543 & 0.260 & 0.042 \\
\hline $\operatorname{COMM}(54)$ & 0.527 & -0.695 & 0.123 \\
\hline СОМM (63) & 0.526 & 0.080 & -0.068 \\
\hline COMM (55) & 0.450 & -0.886 & 0.074 \\
\hline $\operatorname{COMM}(66)$ & 0.432 & -0.093 & -0.577 \\
\hline $\operatorname{COMM}(57)$ & 0.430 & 0.016 & 0.446 \\
\hline $\operatorname{COMM}(53)$ & 0.307 & -0.081 & 0.094 \\
\hline
\end{tabular}

VARIANCE EXPLAINED BY FACTORS

$\begin{array}{lll}1 & 2 & 3 \\ 5.846 & 1.566 & 0.908\end{array}$

PERCENT OF TOTAL VARIANCE EXPLAINED

$\begin{array}{ccc}1 & 2 & 3 \\ 34.386 & 9.212 & 5.340\end{array}$

ROTATED EACTOR PATTERN 
1

2

3

$\begin{array}{lrrr}\operatorname{COM}(64) & 0.829 & 0.198 & 0.193 \\ \operatorname{COM}(52) & 0.626 & 0.152 & 0.193 \\ \operatorname{COM}(58) & 0.617 & 0.030 & 0.344 \\ \operatorname{COM}(61) & 0.603 & 0.102 & 0.331 \\ \operatorname{COM}(60) & 0.588 & 0.161 & 0.157 \\ \operatorname{COM}(57) & 0.556 & 0.228 & -0.153 \\ \operatorname{COM}(62) & 0.548 & -0.044 & 0.249 \\ \operatorname{COM}(56) & 0.543 & -0.008 & 0.287 \\ \operatorname{COM}(59) & 0.542 & 0.035 & 0.511 \\ \operatorname{COM}(55) & 0.030 & 0.980 & 0.178 \\ \operatorname{COM}(54) & 0.191 & 0.842 & 0.176 \\ \operatorname{COM}(66) & 0.022 & 0.108 & 0.718 \\ \operatorname{COM}(67) & 0.336 & 0.197 & 0.657 \\ \operatorname{COM}(65) & 0.391 & 0.251 & 0.459 \\ \operatorname{COM}(68) & 0.338 & 0.205 & 0.423 \\ \operatorname{COM}(63) & 0.409 & 0.090 & 0.334 \\ \operatorname{COM}(53) & 0.252 & 0.199 & 0.082\end{array}$

VARIANCE EXPLAINED BY ROTATED EACTORS

$\begin{array}{lll}1 & 2 & 3 \\ 4.015 & 2.028 & 2.276\end{array}$

PERCENT OE TOTAL VARIANCE EXPLAINED

2

3

$\begin{array}{lll}23.619 & 11.931 & 13.387\end{array}$ 
ITERATIVE PRINCIPAL AXIS FACTOR ANALYSIS

$\begin{array}{cc}\text { ITERATION MAXIMUM CHANGE IN COMMUNAITIES } \\ 1 & 0.6408 \\ 2 & 0.2013 \\ 3 & 0.0572 \\ 4 & 0.0165 \\ 5 & 0.0101 \\ 6 & 0.0076 \\ 7 & 0.0063 \\ 8 & 0.0056 \\ 9 & 0.0050 \\ 10 & 0.0046 \\ 11 & 0.0042 \\ 12 & 0.0039 \\ 13 & 0.0036 \\ 14 & 0.0033 \\ 15 & 0.0031 \\ 16 & 0.0028 \\ 17 & 0.0026 \\ 18 & 0.0024 \\ 19 & 0.0022 \\ 20 & 0.0021 \\ 21 & 0.0019 \\ 22 & 0.0017 \\ 23 & 0.0016 \\ 24 & 0.0015 \\ 25 & 0.0014 \\ 26 & 0.0013 \\ 27 & 0.0012 \\ 28 & 0.0011 \\ 29 & 0.0010 \\ & \end{array}$

EINAL COMMUNALITY ESTIMATES

$\begin{array}{llll}1 & 2 & 3 & 4 \\ 0.572 & 0.128 & 0.800 & 0.969\end{array}$

LATENT ROOTS (EIGENVALUES)

1

2

3

5

5.915

1.575

0.930

0.875

0.497

6

7

8

9

10

0.344

0.310

0.143

0.087

0.043 


$\begin{array}{lllll}21 & 12 & : 3 & : 4 & 15 \\ -0.048 & -0.079 & -0.161 & -0.192 & -0.246 \\ 16 & 17 & & \\ -0.306 & -0.393 & & & \end{array}$

FACTOR PATTERN

\begin{tabular}{|c|c|c|c|c|}
\hline & 1 & 2 & 3 & 4 \\
\hline $\operatorname{COMM}(64)$ & 0.809 & 0.139 & 0.173 & 0.219 \\
\hline $\operatorname{COMM}(61)$ & 0.727 & 0.196 & 0.296 & -0.489 \\
\hline COMM (59) & 0.703 & 0.179 & -0.097 & -0.188 \\
\hline $\operatorname{COM}(67)$ & 0.673 & -0.058 & -0.281 & -0.261 \\
\hline $\operatorname{COMM}(58)$ & 0.668 & 0.207 & 0.000 & 0.004 \\
\hline COMM (52) & 0.650 & 0.104 & 0.025 & 0.372 \\
\hline $\operatorname{COMM}(65)$ & 0.627 & -0.085 & -0.135 & -0.053 \\
\hline $\operatorname{com}(60)$ & 0.621 & 0.110 & 0.408 & -0.285 \\
\hline СОMM (56) & 0.577 & 0.221 & -0.124 & 0.262 \\
\hline $\operatorname{COMM}(68)$ & 0.554 & -0.068 & -0.228 & 0.055 \\
\hline $\operatorname{COMM}(52)$ & 0.542 & 0.253 & -0.053 & 0.280 \\
\hline $\operatorname{COMM}(63)$ & 0.526 & 0.066 & -0.194 & 0.181 \\
\hline COMM (54) & 0.524 & -0.711 & 0.100 & 0.101 \\
\hline Coms (55) & 0.443 & -0.873 & 0.098 & -0.022 \\
\hline $\operatorname{COMM}(66)$ & 0.427 & -0.103 & -0.519 & -0.228 \\
\hline COMM (57) & 0.427 & 0.014 & 0.374 & 0.195 \\
\hline $\operatorname{COMM}(53)$ & 0.306 & -0.089 & 0.040 & 0.158 \\
\hline
\end{tabular}

VARIANCE EXPLAINED BY EACTORS

$\begin{array}{llll}1 & 2 & 3 & 4 \\ 5.915 & 1.575 & 0.930 & 0.875\end{array}$

PERCENT OE TOTAL VARTANCE EXPLAINED

2

3

4

34.793

9.267

5.471

5.147

ROTATED EACTOR PATTERN

2

3

4

$\operatorname{COMM}(66)$

0.704

0.103

0.024

0.093 


$\begin{array}{lrrrl}\operatorname{COMM}(67) & 0.639 & 0.184 & 0.318 & 0.244 \\ \operatorname{COMM}(55) & 0.188 & 0.962 & 0.091 & 0.003 \\ \operatorname{COMM}(54) & 0.163 & 0.853 & 0.099 & 0.191 \\ \operatorname{COMM}(61) & 0.288 & 0.059 & 0.877 & 0.196 \\ \operatorname{COMM}(60) & 0.073 & 0.148 & 0.748 & 0.241 \\ \operatorname{COMM}(64) & 0.135 & 0.191 & 0.419 & 0.722 \\ \operatorname{COMM}(52) & 0.118 & 0.159 & 0.154 & 0.714 \\ \operatorname{COMM}(56) & 0.239 & -0.014 & 0.122 & 0.627 \\ \operatorname{COMM}(62) & 0.200 & -0.049 & 0.201 & 0.557 \\ \operatorname{COMM}(58) & 0.290 & 0.025 & 0.388 & 0.503 \\ \operatorname{COMM}(63) & 0.314 & 0.089 & 0.065 & 0.491 \\ \operatorname{COMM}(57) & -0.180 & 0.221 & 0.326 & 0.415 \\ \operatorname{COMM}(59) & 0.463 & 0.021 & 0.455 & 0.385 \\ \operatorname{COMM}(68) & 0.414 & 0.200 & 0.101 & 0.381 \\ \operatorname{COMM}(65) & 0.419 & 0.246 & 0.253 & 0.348 \\ \operatorname{COMM}(53) & 0.049 & 0.205 & 0.067 & 0.281\end{array}$

VARIANCE EXPLAINED BY ROTATED FACTORS

$\begin{array}{llll}1 & 2 & 3 & 4 \\ 1.962 & 1.988 & 2.250 & 3.095\end{array}$

PERCENT OF TOTAL VARIANCE EXPLAINED

1

11.543

11.695
3

13.234
4

18.206 
APPENDIX $\mathrm{H}$

RELIABILITY MATRICES AND TABLES 
PEARSON CORRELATION MATRIX

$\begin{array}{lrrrrr} & \operatorname{DESN}(8) & \operatorname{DESN}(10) & \operatorname{DESN}(13) & \operatorname{DESN}(6) & \operatorname{DESN}(7) \\ & & & & \\ \operatorname{DESN}(8) & 1.000 & & & & \\ \operatorname{DESN}(10) & 0.562 & 1.000 & & & \\ \operatorname{DESN}(13) & 0.440 & 0.558 & 1.000 & & \\ \operatorname{DESN}(6) & 0.515 & 0.529 & 0.697 & 1.000 & 1.000 \\ \operatorname{DESN}(7) & 0.549 & 0.506 & 0.475 & 0.497 & 0.488 \\ \operatorname{DESN}(9) & 0.517 & 0.685 & 0.476 & 0.364 & 0.457 \\ \operatorname{DESN}(14) & 0.471 & 0.357 & 0.482 & 0.495 & \end{array}$

DESN (9) DESN (14)

$\begin{array}{ll}\operatorname{DESN}(9) & 1.000 \\ \operatorname{DESN}(14) & 0.400\end{array}$

EREQUENCY TABLE

$\operatorname{DESN}(\theta) \quad \operatorname{DESN}(10) \operatorname{DESN}(13) \quad \operatorname{DESN}(6) \quad \operatorname{DESN}(7)$

$\operatorname{DESN}(8)$
$\operatorname{DESN}(10)$
$\operatorname{DESN}(13)$
$\operatorname{DESN}(6)$
$\operatorname{DESN}(7)$
$\operatorname{DESN}(9)$
$\operatorname{DESN}(14)$

DESN (9) DESN (14)

DESN (9)

DESN (14) 
PEARSON CORRELATION MATRIX

$\begin{array}{lrr} & \operatorname{DESN}(3) & \operatorname{DESN}(4) \\ & & \\ \operatorname{DESN}(3) & 1.000 & \\ \operatorname{DESN}(4) & 0.623 & 1.000\end{array}$

NUMBER OF OBSERVATIONS: 
PEARSON CORRELATION MATRIX

DESN (2) DESN (11)

$\begin{array}{lll}\operatorname{DESN}(2) & 1.000 & \\ \operatorname{DESN}(11) & 0.397 & 1.000\end{array}$

FREQUENCY TABLE

$\operatorname{DESN}(2) \quad \operatorname{DESN}(11)$

$\operatorname{DESN}(2)$

DESN (11)

58
56

57 
PEARSON CORRELATION MATRIX

$\begin{array}{lrrrrr} & \operatorname{cosT}(32) & \operatorname{cosT}(30) & \operatorname{cosT}(24) & \operatorname{cosT}(33) & \operatorname{cosT}(31) \\ \operatorname{cosT}(32) & 1.000 & & & & \\ \operatorname{cosT}(30) & 0.437 & 1.000 & & & \\ \operatorname{cosT}(24) & 0.275 & 0.404 & 1.000 & & \\ \operatorname{cosT}(33) & 0.449 & 0.550 & 0.466 & 1.000 & \\ \operatorname{cosT}(31) & 0.429 & 0.366 & 0.507 & 0.319 & 1.000\end{array}$

EREQUENCY TABLE

$\cos (32) \quad \cos (30) \quad \cos (24) \quad \cos T(33) \quad \cos T(31)$

$\operatorname{cost}(32)$

$\cos \mathrm{T}(30)$

$\operatorname{cost}(24)$

$\operatorname{cost}(33)$

$\cos T(31)$

56
55
56
56

55
55

55
55

56 
PEARSON CORRELATION MATRIX

$\begin{array}{lrrr} & \operatorname{cosT}(18) & \operatorname{cosT}(19) & \operatorname{cosT}(29) \\ & & & \\ \operatorname{cosT}(18) & 1.000 & & \\ \operatorname{cosT}(19) & 0.578 & 1.000 & \\ \operatorname{cosT}(29) & 0.402 & 0.561 & 1.000\end{array}$

FREQUENCY TABLE

$\begin{array}{lrrr} & \operatorname{cosT}(18) & \operatorname{cosT}(19) & \operatorname{cosT}(29) \\ & & & \\ \cos T(18) & 56 & & \\ \operatorname{cosT}(19) & 56 & 56 & \\ \operatorname{cosT}(29) & 54 & 54 & 55\end{array}$


PEARSON CORRELATION MATRIX

$\begin{array}{lrrrrr} & \operatorname{cosT}(20) & \operatorname{cosT}(21) & \operatorname{cosT}(23) & \operatorname{cosT}(25) & \cos 2(26) \\ \operatorname{cosT}(20) & 1.000 & & & & \\ \operatorname{cosT}(21) & 0.738 & 1.000 & & & \\ \operatorname{cosT}(23) & 0.492 & 0.453 & 1.000 & & \\ \operatorname{cosT}(25) & 0.399 & 0.492 & 0.418 & 1.000 & \\ \operatorname{cosT}(26) & 0.306 & 0.427 & 0.402 & 0.545 & 1.000\end{array}$

EREQUENCY TABLE

$\begin{array}{lrrrrr} & \operatorname{cosT}(20) & \operatorname{cosT}(21) & \operatorname{cosT}(23) & \operatorname{cosT}(25) & \cos 2(26) \\ \operatorname{cosT}(20) & 55 & & & & \\ \operatorname{cosT}(21) & 55 & 55 & & & \\ \operatorname{cosT}(23) & 55 & 55 & 55 & 56 & \\ \operatorname{cosT}(25) & 55 & 55 & 55 & 56 & 56 \\ \operatorname{cosT}(26) & 55 & 55 & 55 & \end{array}$


PEARSON CORRELATION MATRIX

\begin{tabular}{|c|c|c|c|c|c|}
\hline & $\operatorname{TIME}(48)$ & $\operatorname{TIME}(50)$ & $\operatorname{TIME}(49)$ & $\operatorname{TIME}(42)$ & $\operatorname{TIME}(44)$ \\
\hline $\begin{array}{l}\operatorname{TIME}(48) \\
\operatorname{TIME}(50) \\
\operatorname{TIME}(49) \\
\operatorname{TIME}(42) \\
\operatorname{TIME}(44) \\
\operatorname{TIME}(52)\end{array}$ & $\begin{array}{l}1.000 \\
0.733 \\
0.589 \\
0.559 \\
0.544 \\
0.592\end{array}$ & $\begin{array}{l}1.000 \\
0.447 \\
0.437 \\
0.471 \\
0.563\end{array}$ & $\begin{array}{l}1.000 \\
0.442 \\
0.483 \\
0.305\end{array}$ & $\begin{array}{l}1.000 \\
0.770 \\
0.494\end{array}$ & $\begin{array}{l}1.000 \\
0.370\end{array}$ \\
\hline & $\operatorname{TIME}(51)$ & & & & \\
\hline TIME (51) & 1.000 & & & & \\
\hline
\end{tabular}

EREQUENCY TABLE

\begin{tabular}{|c|c|c|c|c|c|}
\hline & $\operatorname{TIME}(48)$ & $\operatorname{TIME}(50)$ & $\operatorname{TIME}(49)$ & $\operatorname{TIME}(42)$ & TIME (44) \\
\hline $\operatorname{TIME}(48)$ & 52 & & & & \\
\hline TIME (50) & 51 & 52 & & & \\
\hline $\operatorname{TIME}(49)$ & 52 & 52 & 53 & & \\
\hline TIME (42) & 52 & 52 & 53 & 53 & \\
\hline $\operatorname{TIME}(44)$ & 52 & 52 & 53 & 53 & 53 \\
\hline TIME (51) & 52 & 52 & 53 & 53 & 53 \\
\hline
\end{tabular}

TIME (51)

TIME (51) 
PEARSON CORRELATION MATRIX

$\begin{array}{lrr} & \operatorname{TIME}(38) & \operatorname{TIME}(37) \\ & & \\ \operatorname{TIME}(38) & 1.000 & \\ \operatorname{TIME}(37) & 0.794 & 1.000\end{array}$

NUMBER OF OBSERVATIONS: 54 
PEARSON CORRELATION MATRIX

$\begin{array}{lrr} & \operatorname{TIME}(36) & \operatorname{TIME}(45) \\ \operatorname{TIME}(36) & 1.000 & \\ \operatorname{TIME}(45) & 0.475 & 1.000 \\ & & \\ \text { EREQUENCY TABLE } & & \\ & & \\ & & \\ & & \\ & & \\ & & \\ \operatorname{TIME}(36) & & \\ \operatorname{TIME}(36) & 55 & \end{array}$


PEARSON CORRELATION MATRIX

\begin{tabular}{|c|c|c|c|c|c|}
\hline & $\operatorname{COM}(64)$ & $\operatorname{COM}(52)$ & $\operatorname{COMM}(58)$ & $\operatorname{COMM}(61)$ & $\operatorname{COM}(60)$ \\
\hline $\begin{array}{l}\operatorname{COM}(64) \\
\operatorname{COM}(52) \\
\operatorname{COM}(58) \\
\operatorname{COM}(61) \\
\operatorname{COM}(60) \\
\operatorname{COM}(57) \\
\operatorname{COM}(62) \\
\operatorname{COM}(56) \\
\operatorname{COMM}(59)\end{array}$ & $\begin{array}{l}1.000 \\
0.608 \\
0.533 \\
0.583 \\
0.494 \\
0.533 \\
0.555 \\
0.503 \\
0.475\end{array}$ & $\begin{array}{l}1.000 \\
0.394 \\
0.343 \\
0.296 \\
0.357 \\
0.463 \\
0.571 \\
0.438\end{array}$ & $\begin{array}{l}1.000 \\
0.476 \\
0.484 \\
0.312 \\
0.426 \\
0.503 \\
0.504\end{array}$ & $\begin{array}{l}1.000 \\
0.733 \\
0.338 \\
0.358 \\
0.328 \\
0.623\end{array}$ & $\begin{array}{l}1.000 \\
0.305 \\
0.275 \\
0.273 \\
0.483\end{array}$ \\
\hline & $\operatorname{COMM}(57)$ & $\operatorname{COM}(62)$ & $\operatorname{COM}(56)$ & $\operatorname{CoMM}(59)$ & \\
\hline $\begin{array}{l}\operatorname{COMM}(57) \\
\operatorname{COMM}(62) \\
\operatorname{COM}(56) \\
\operatorname{COMM}(59)\end{array}$ & $\begin{array}{l}1.000 \\
0.227 \\
0.216 \\
0.263\end{array}$ & $\begin{array}{l}1.000 \\
0.409 \\
0.391\end{array}$ & $\begin{array}{l}1.000 \\
0.323\end{array}$ & 1.000 & \\
\hline
\end{tabular}

FREQUENCY TABLE

$\operatorname{com}(64)$

58
58
57
57
58
57
58
57
58

$\operatorname{COMM}(57)$
$\operatorname{COM} M(52)$

COMM (64)

COMM (52)

$\operatorname{com}(58)$

$\operatorname{COM}(6)$

COMM $(60)$

Coms (57)

$\cos M(62)$

COMM (56)

COMM (59)

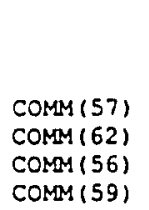

$\operatorname{com} M(62)$

$\operatorname{COMM}(56)$

$\operatorname{Com} M(59)$
$\operatorname{COM}(61) \operatorname{COM}(60)$

$\begin{array}{lll}57 & & \\ 57 & 57 & \\ 57 & 57 & 58 \\ 56 & 56 & 57 \\ 57 & 57 & 58 \\ 57 & 57 & 57 \\ 57 & 57 & 58\end{array}$

57 
PEARSON CORRELATION MATRIX

$\operatorname{COM} M(55) \quad \operatorname{COMM}(54)$

$\begin{array}{lll}\operatorname{COM}(55) & 1.000 & \\ \operatorname{COM}(54) & 0.861 & 1.000\end{array}$

NUMBER OF OBSERVATIONS: , 58 
PEARSON CORRELATION MATRIX

$\begin{array}{lrr} & \operatorname{COMM}(66) & \operatorname{COMM}(67) \\ & & \\ \operatorname{COMM}(66) & 1.000 & \\ \operatorname{COMM}(67) & 0.499 & 1.000 \\ & & \\ & & \\ & & \\ & & \\ & & \\ & & \\ & & \\ & & \\ \operatorname{COMM}(66) & \operatorname{COMM}(67) \\ \operatorname{COMM}(66) & 58 & 57 \\ \operatorname{COMM}(67) & 57 & \end{array}$


APPENDIX I

MANOVA ANALYSES 
14 CASES DELETED DUE TO MISSING DATA. NUMBER OF CASES PROCESSED: 51

DEPENDENT VARIABLE MEANS

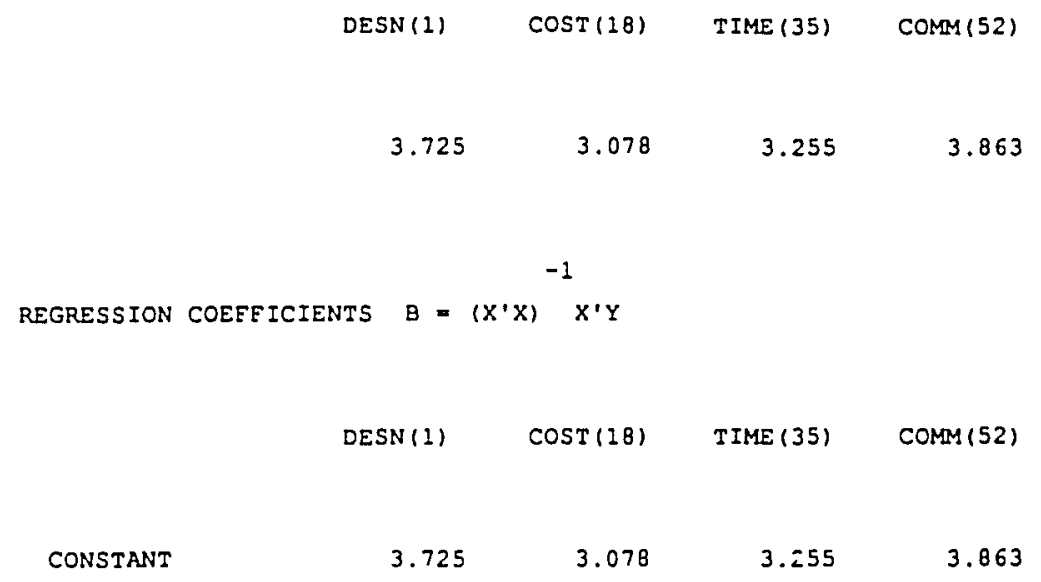

MULTIPLE CORRELATIONS

DESN(1) COST(18) TIME (35) COMM(52)
0.000
0.000
0.000
0.000

HYPOTHESIS. 
C MATRIX

\begin{tabular}{rrrrr} 
& 1 & \multicolumn{1}{l}{2} & \multicolumn{1}{l}{3} & \multicolumn{1}{l}{4} \\
1 & 1.000 & -1.000 & 0.000 & 0.000 \\
3 & 0.000 & 1.000 & -1.000 & 0.000 \\
& 0.000 & 0.000 & 1.000 & -1.000
\end{tabular}

UNIVARIATE F TESTS

\begin{tabular}{rrrrrl} 
VARIABLE & \multicolumn{1}{l}{ SS } & DE & \multicolumn{1}{l}{ MS } & F & P \\
& & & & & \\
ERROR & 21.353 & 1 & 21.353 & 38.617 & 0.000 \\
2 & 27.647 & 50 & 0.553 & & \\
ERROR & 1.588 & 1 & 1.588 & 3.125 & 0.083 \\
3 & 25.412 & 50 & 0.508 & & \\
ERROR & 18.843 & 1 & 18.843 & 17.397 & 0.000
\end{tabular}

MULTIVARIATE TEST STATISTICS

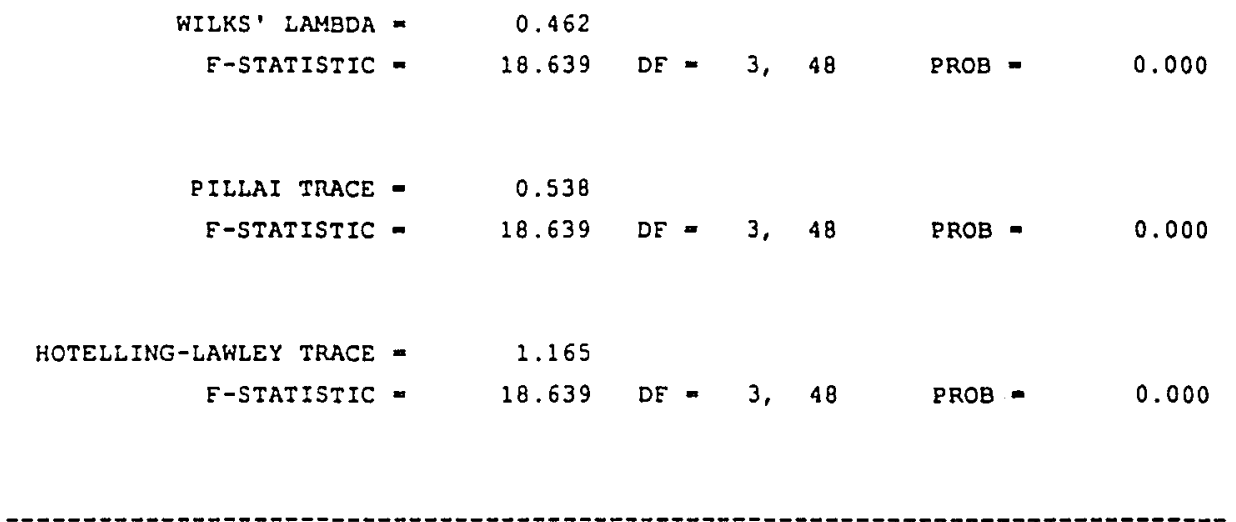

14 CASES DELETED DUE TO MISSING DATA. 
NUMBER OF CASES PROCESSED: 51

DEPENDENT VARIABLE MEANS

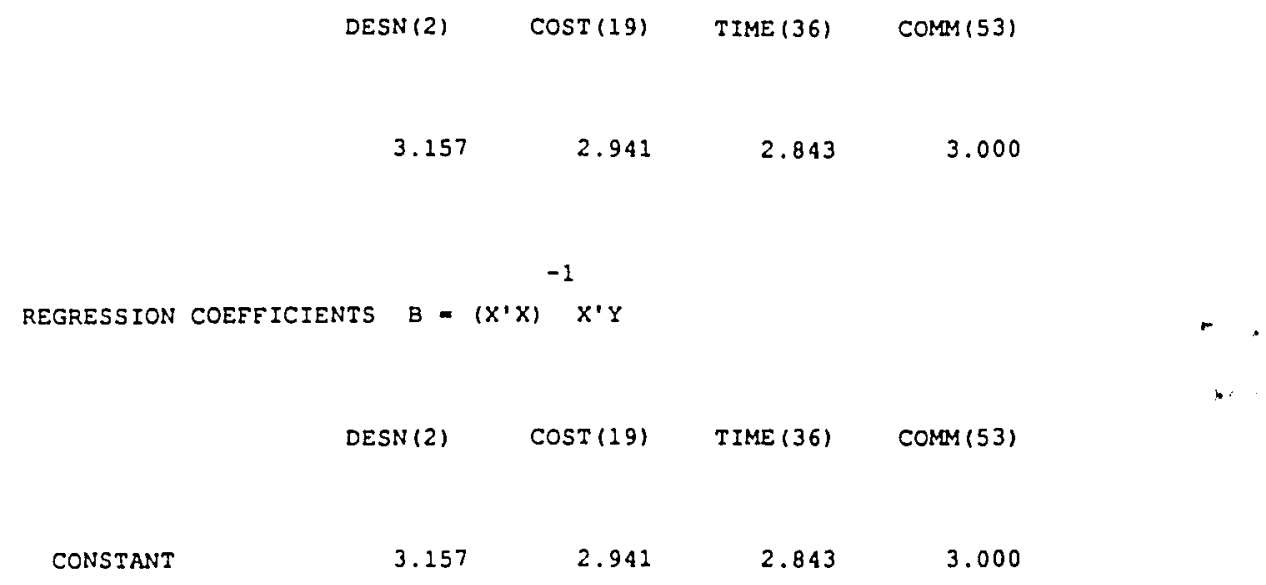

MULTIPLE CORRELATIONS

DESN(2) COST(19) TIME(36) COMM(53)

$\begin{array}{llll}0.000 & 0.000 & 0.000 & 0.000\end{array}$

HYPOTHESIS 
C MATRIX

\begin{tabular}{rrrrr} 
& 1 & 2 & \multicolumn{1}{c}{3} & \multicolumn{1}{l}{4} \\
1 & 1.000 & -1.000 & 0.000 & 0.000 \\
2 & 0.000 & 1.000 & -1.000 & 0.000 \\
3 & 0.000 & 0.000 & 1.000 & -1.000
\end{tabular}

UNIVARIATE E TESTS

\begin{tabular}{rrrlll} 
VARIABLE & \multicolumn{1}{l}{ SS } & DF & MS & F & P \\
& & & & & \\
ERROR & 38.627 & 50 & 0.773 & & \\
2 & 0.490 & 1 & 0.490 & 0.060 & 0.086 \\
ERROR & 28.510 & 50 & 0.570 & & 0.358 \\
3 & 1.255 & 1 & 1.255 & 0.913 & 0.344 \\
ERROR & 68.745 & 50 & 1.375 & &
\end{tabular}

MULTIVARIATE TEST STATISTICS

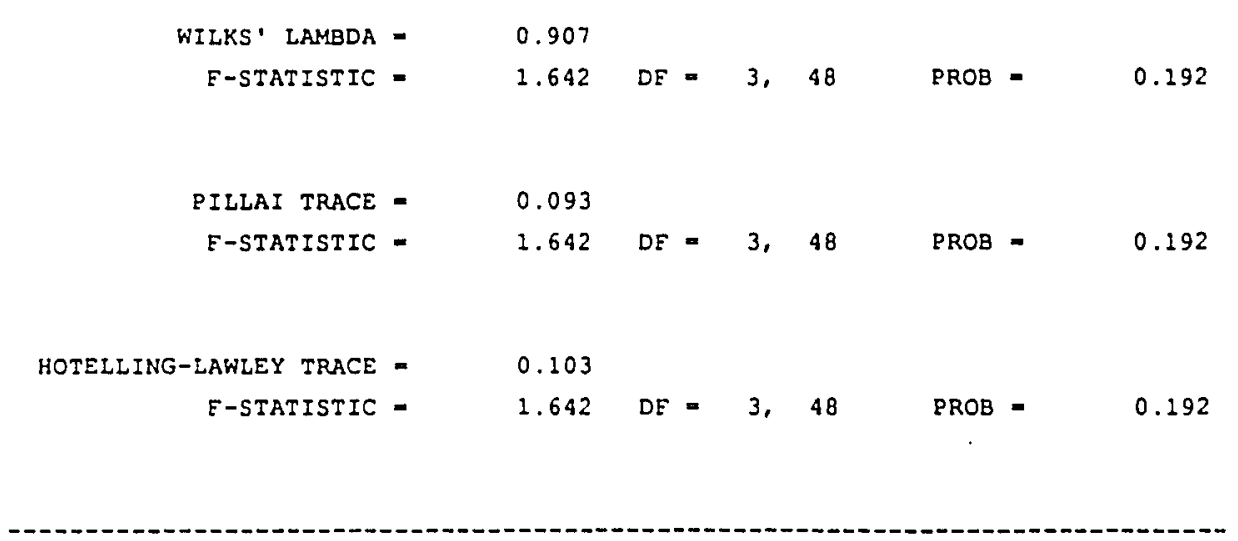

15 CASES DELETED DUE TO MISSING DATA.

NUMBER OF CASES PROCESSED: 50 
DEPENDENT VARTABLE MEANS

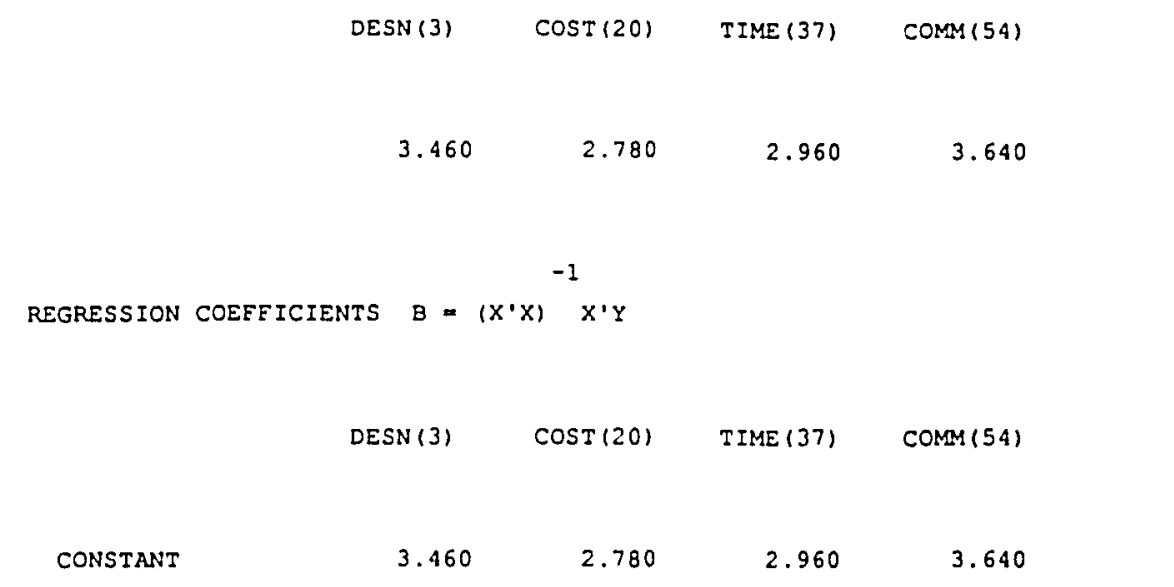

MULTIPLE CORRELATIONS

$\begin{array}{rrrr}\operatorname{DESN}(3) & \operatorname{COST}(20) & \operatorname{TIME}(37) & \operatorname{COMM}(54) \\ & & & \\ 0.000 & 0.000 & 0.000 & 0.000\end{array}$

HYPOTHESIS.

C MATRIX 


\begin{tabular}{|c|c|c|c|c|c|c|}
\hline & \multicolumn{2}{|l|}{1} & 2 & 3 & & \\
\hline & \multicolumn{2}{|c|}{1.000} & -1.000 & 0.000 & & \\
\hline & \multicolumn{2}{|c|}{0.000} & 1.000 & -1.000 & & \\
\hline & \multicolumn{2}{|c|}{0.000} & 0.000 & 1.000 & & \\
\hline \multicolumn{7}{|c|}{ UNIVARIATE E TESTS } \\
\hline VARIABLE & ss & $D F$ & MS & & E & $\mathbf{P}$ \\
\hline 1 & 23.120 & 1 & 23.120 & \multirow{2}{*}{\multicolumn{2}{|c|}{11.694}} & 0.001 \\
\hline ERROR & 96.880 & 49 & 1.977 & & & \\
\hline 2 & 1.620 & 1 & 1.620 & \multirow{2}{*}{\multicolumn{2}{|c|}{1.487}} & 0.229 \\
\hline ERROR & 53.380 & 49 & 1.089 & & & \\
\hline 3 & 23.120 & 1 & 23.120 & \multirow{2}{*}{\multicolumn{2}{|c|}{14.736}} & 0.000 \\
\hline ERROR & 76.880 & 49 & 1.569 & & & \\
\hline
\end{tabular}

MULTIVARIATE TEST STATISTICS

\begin{tabular}{|c|c|c|c|c|c|c|c|}
\hline \multirow{2}{*}{$\begin{array}{l}\text { WILKS' LAMBDA } \\
\text { E-STATISTIC }\end{array}$} & \multicolumn{7}{|l|}{0.692} \\
\hline & 6.981 & $\mathrm{DF}=$ & 3. & 47 & PROB & - & 0.001 \\
\hline PILLAI TRACE & 0.308 & & & & & & \\
\hline E-STATISTIC & 6.981 & $\mathrm{DE}=$ & 3, & 47 & PROB & - & 0.001 \\
\hline HOTELLING-LAWLEY TRACE - & 0.446 & & & & & & \\
\hline F-STATISTIC & 6.981 & $\mathrm{DF}=$ & 3, & 47 & PROB & - & 0.001 \\
\hline
\end{tabular}

15 CASES DELETED DUE TO MISSING DATA.

NUMBER OF CASES PROCESSED: 
DEPENDENT VARIABLE MEANS

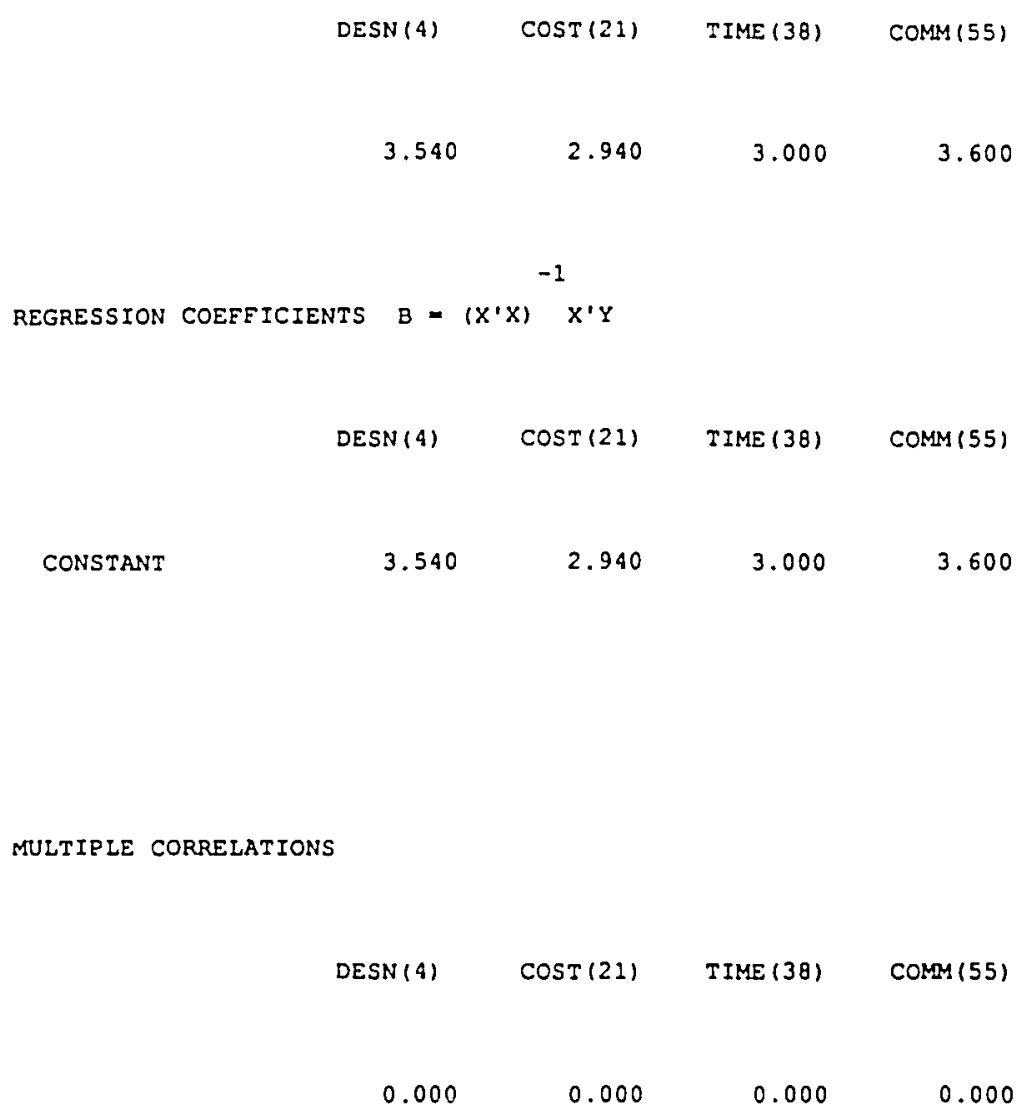

HYPOTHESIS.

C MATRIX 


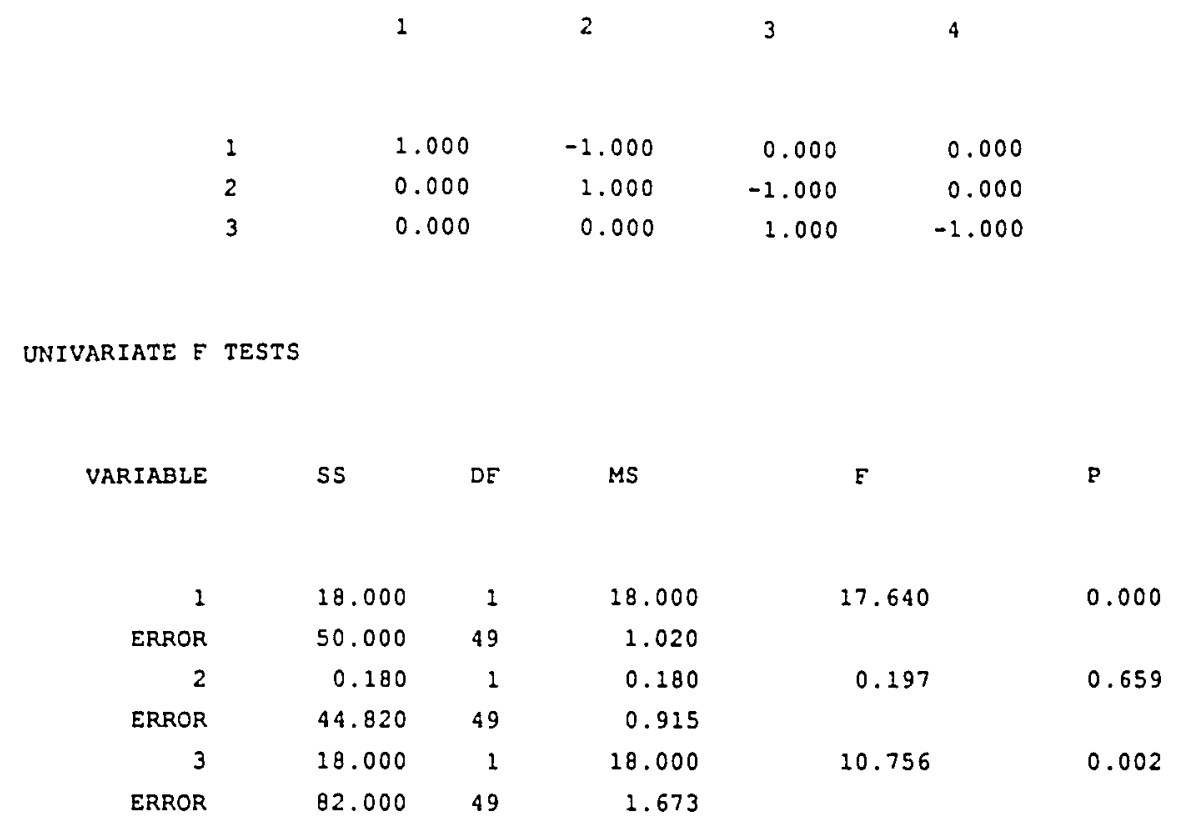

MULTIVARIATE TEST STATISTICS

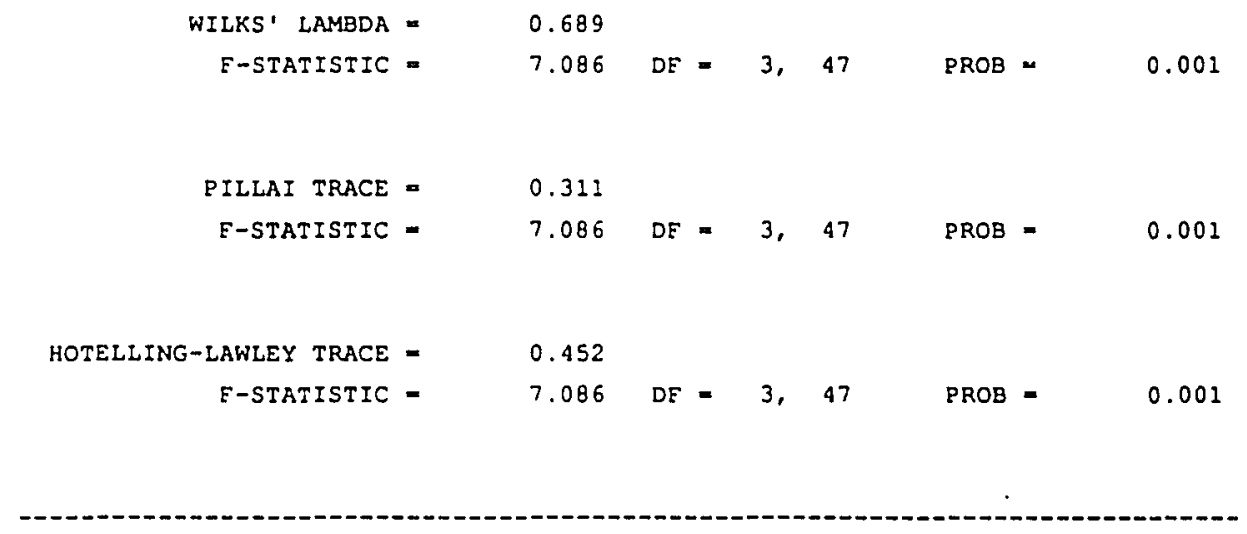

16 CASES DELETED DUE TO MISSING DATA.

NUMBER OF CASES PROCESSED: 
DEPENDENT VARIABLE MEANS

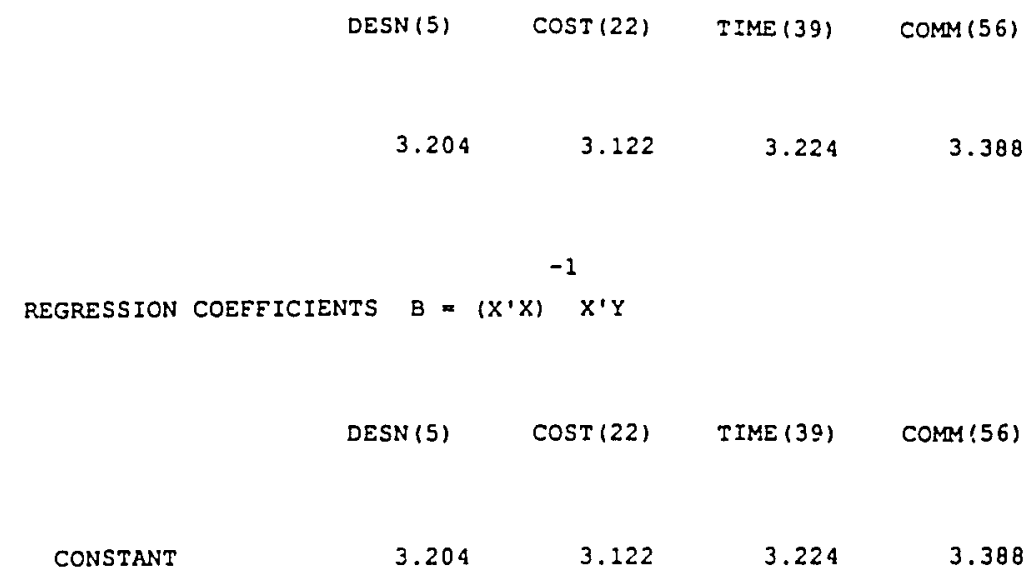

MULTIPLE CORRELATIONS

$\begin{array}{rrrr}\text { DESN (5) } & \operatorname{COST}(22) & \operatorname{TIME}(39) & \operatorname{COMM}(56) \\ 0.000 & 0.000 & 0.000 & 0.000\end{array}$

HYPOTHESIS.

C MATRIX 


$\begin{array}{rrrrr}1 & 1.000 & -1.000 & 0.000 & 0.000 \\ 2 & 0.000 & 1.000 & -1.000 & 0.000 \\ 3 & 0.000 & 0.000 & 1.000 & -1.000\end{array}$

UNIVARIATE F TESTS

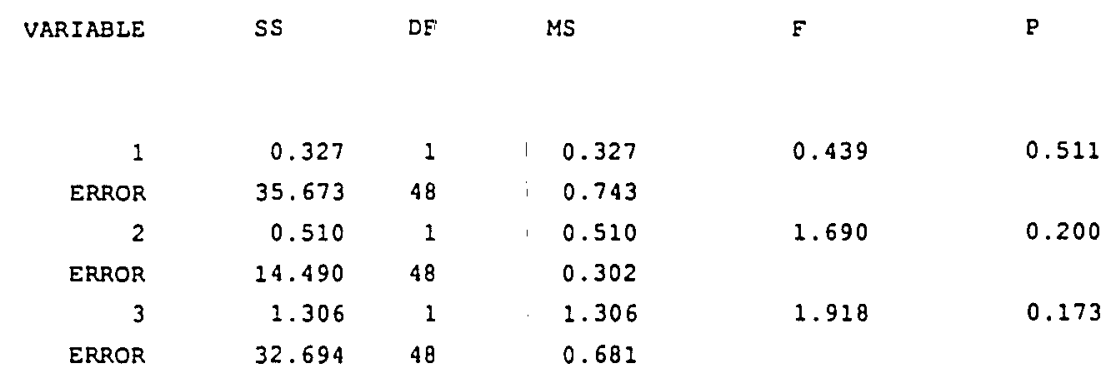

MULTIVARIATE TEST STATISTICS

\begin{tabular}{|c|c|c|c|c|c|c|}
\hline WILKS' LAMBDA = & 0.921 & & & & & \\
\hline E-STATISTIC - & 1.316 & $\mathrm{DE}=$ & 3, & 46 & PROB = & 0.281 \\
\hline PILLAI TRACE = & 0.0719 & & & & & \\
\hline F-STATISTIC $=$ & 1.3116 & $\mathrm{DF}=$ & 3, & 46 & PROB = & 0.281 \\
\hline HOTELLING-LAWLEY TRACE - & 0.0816 & & & & & \\
\hline E-STATISTIC $=$ & 1.3116 & $D F=$ & 3, & 46 & PROB = & 0.281 \\
\hline
\end{tabular}

16 CASES DELETED DUE TO MISSING DATA. NUMBER OE CASES PROCESSED:

DEPENDENT VARIABLE MEANS 


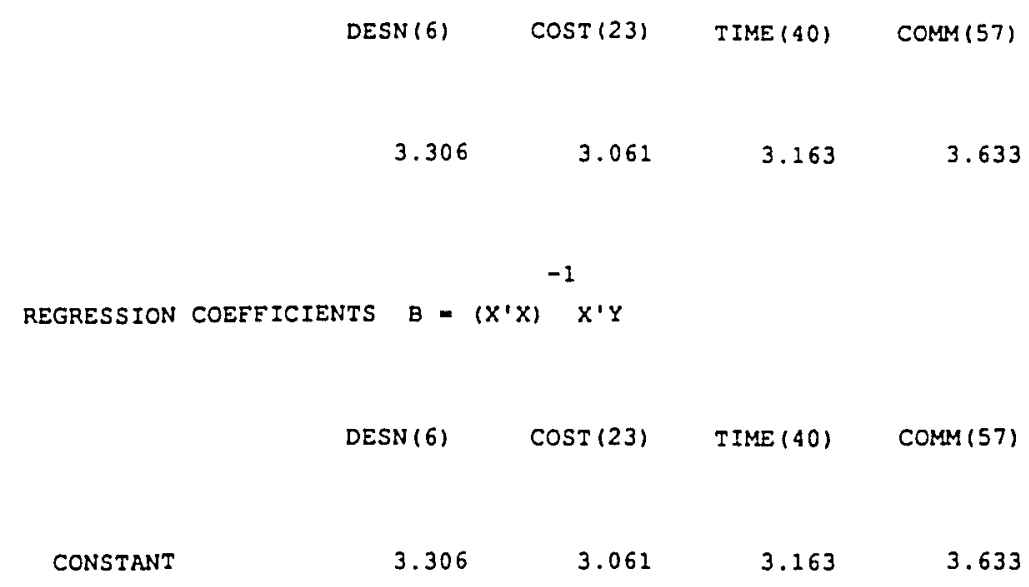

MULTIPLE CORRELATIONS

$\begin{array}{rrrr}\operatorname{DESN}(6) & \operatorname{COST}(23) & \operatorname{TIME}(40) & \operatorname{COMM}(57) \\ 0.000 & 0.000 & 0.000 & 0.000\end{array}$

HYPOTHESIS .

C MATRIX 


$\begin{array}{rrrrr}1 & 1.000 & -1.000 & 0.000 & 0.000 \\ 2 & 0.000 & 1.000 & -1.000 & 0.000 \\ 3 & 0.000 & 0.000 & 1.000 & -1.000\end{array}$

UNIVARIATE F TESTS

VARTABLE

1
ERROR
2
ERROR
3
ERROR

ss

DF

MS

2.939

1.314

0.510

0.677

10.796

1.213
E

2.237

0.754

8.903
0.141

0.390

0.004

MULTIVARIATE TEST STATISTICS

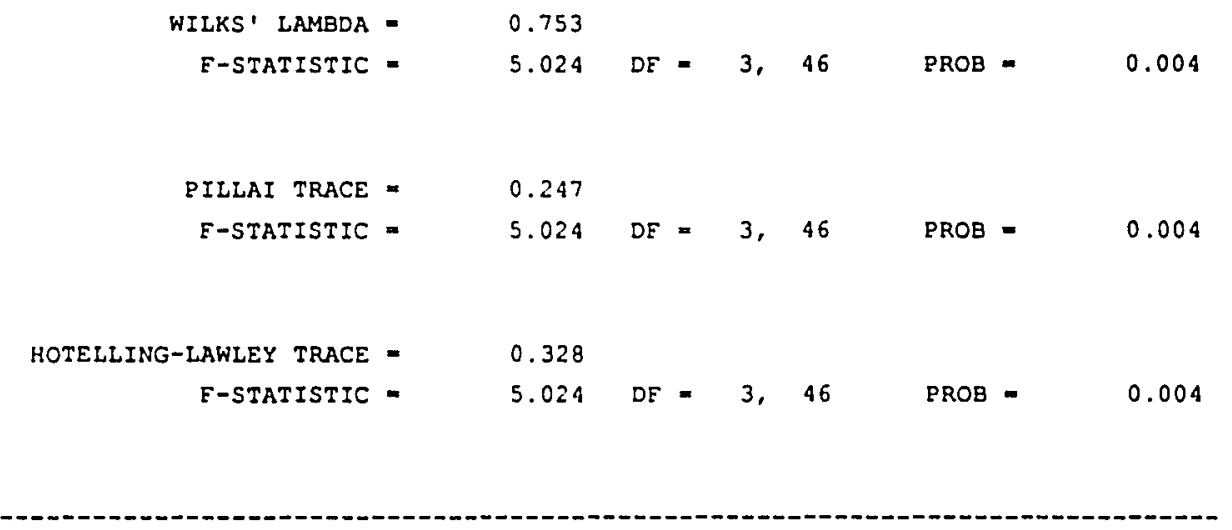

$5.024 \quad D F=3,46 \quad$ PROB -0.004

20 CASES DELETED DUE TO MISSING DATA.

NUMBER OE CASES PROCESSED:

DEPENDENT VARIABLE MEANS 


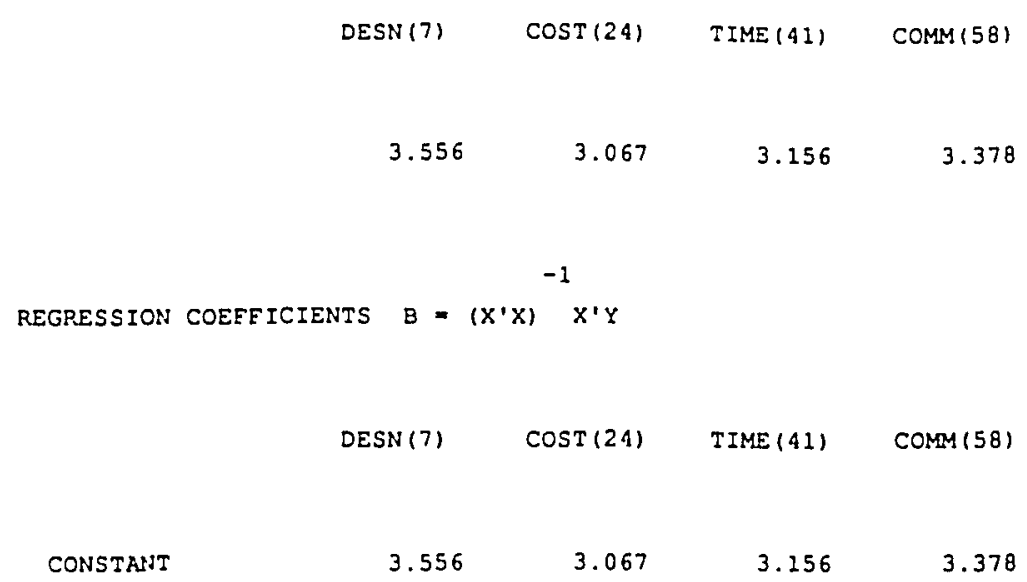

MULTIPLE CORRELATIONS

$\operatorname{DESN}(7) \quad \operatorname{COST}(24) \quad \operatorname{TIME}(41) \quad \operatorname{COM}(58)$

$\begin{array}{llll}0.000 & 0.000 & 0.000 & 0.000\end{array}$

HYPOTHESIS.

C MATRIX 


$\begin{array}{rrrrr}1 & 1.000 & -1.000 & 0.000 & 0.000 \\ 2 & 0.000 & 1.000 & -1.000 & 0.000 \\ 3 & 0.000 & 0.000 & 1.000 & -1.000\end{array}$

UNIVARIATE F TESTS

\begin{tabular}{rrrlll} 
VARIABLE & \multicolumn{1}{l}{ SS } & DE & \multicolumn{1}{l}{ MS } & F & P \\
& & & & & \\
1 & 10.756 & 1 & 10.756 & 12.706 & 0.001 \\
ERROR & 37.244 & 44 & 0.846 & & \\
2 & 0.356 & 1 & 0.356 & 0.465 & 0.499 \\
ERROR & 33.644 & 44 & 0.765 & & \\
3 & 2.222 & 1 & 2.222 & 3.520 & 0.067 \\
ERROR & 27.778 & 44 & 0.631 & &
\end{tabular}

MULTIVARIATE TEST STATISTICS

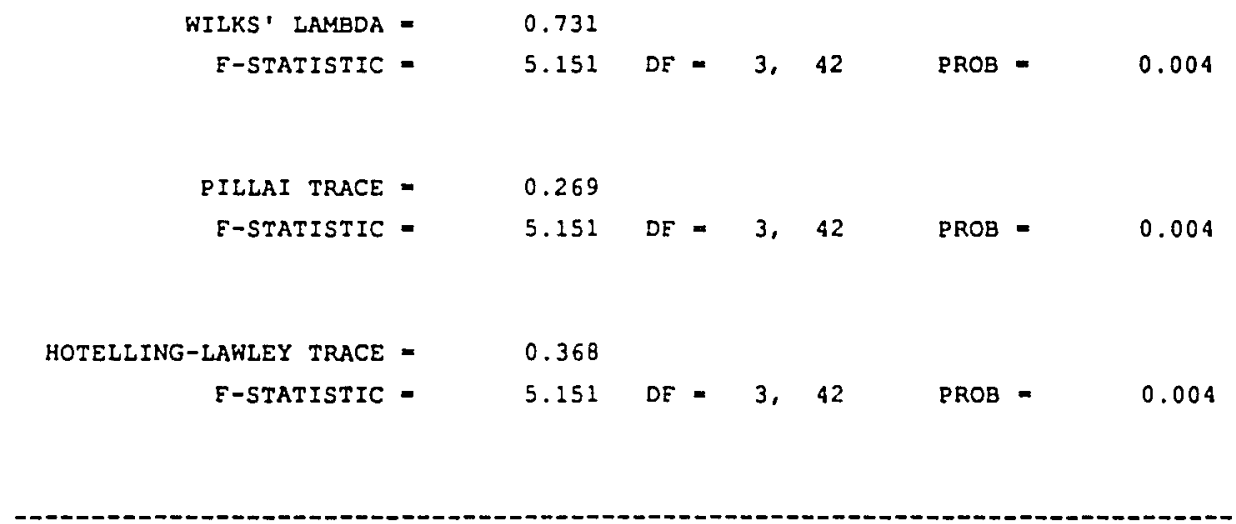

15 CASES DELETED DUE TO MISSING DATA. NUMBER OE CASES PROCESSED: 50

DEPENDENT VARIABLE MEANS 


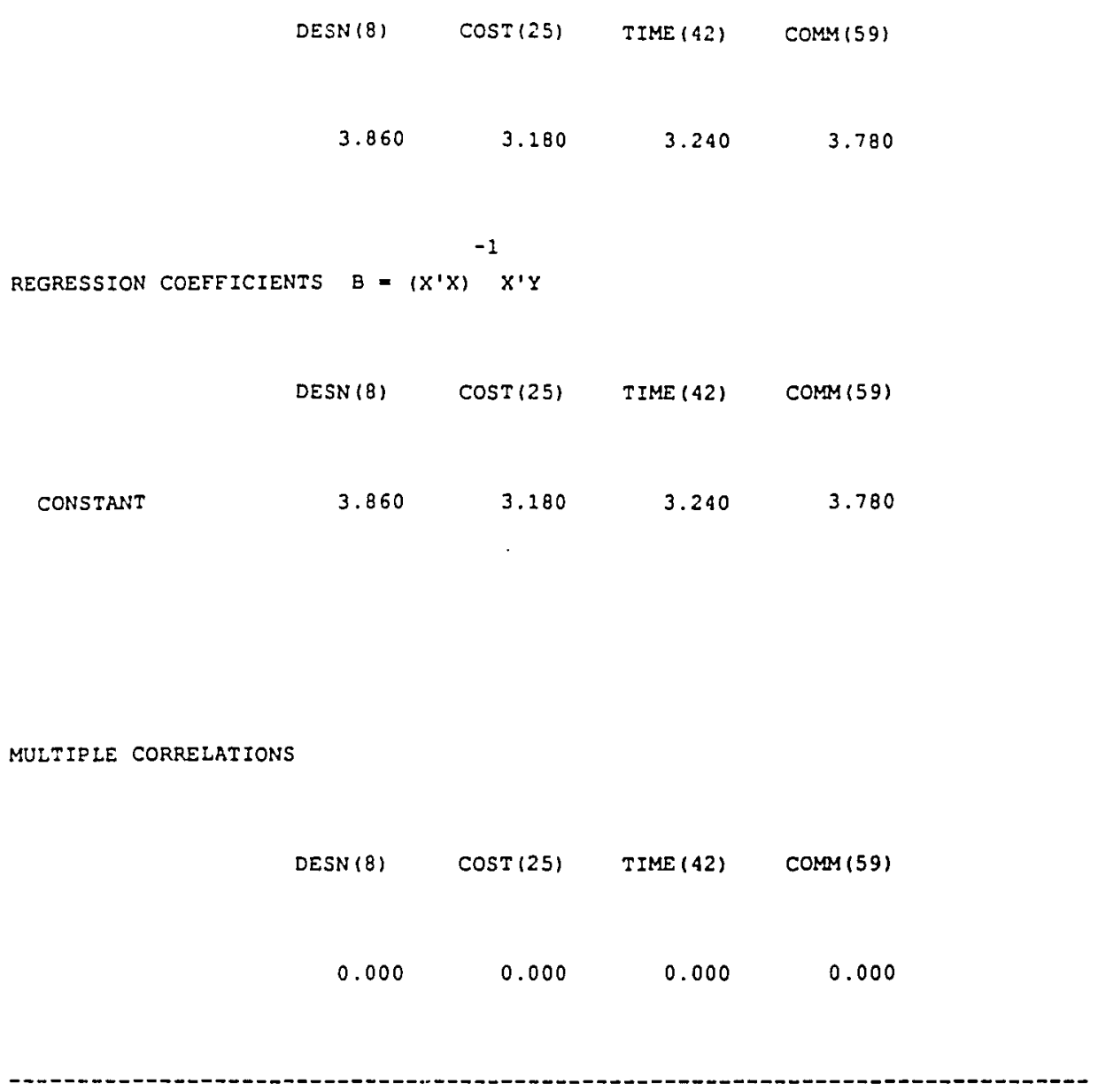

HYPOTHESIS.

C MATRIX 


$\begin{array}{rrrrr}1 & 1.000 & -1.000 & 0.000 & 0.000 \\ 2 & 0.000 & 1.000 & -1.000 & 0.000 \\ 3 & 0.000 & 0.000 & 1.000 & -1.000\end{array}$

UNIVARIATE F TESTS

\begin{tabular}{rrrrll} 
VARIABLE & \multicolumn{1}{l}{ SS } & DF & \multicolumn{1}{l}{ HS } & E & P \\
& & & & & \\
1 & 23.120 & 1 & 23.120 & 21.424 & 0.000 \\
ERROR & 52.880 & 49 & 1.079 & & \\
2 & 0.180 & 1 & 0.180 & 0.253 & 0.617 \\
ERROR & 34.820 & 49 & 0.711 & & \\
3 & 14.580 & 1 & 14.580 & 17.675 & 0.000 \\
ERROR & 40.420 & 49 & 0.825 & &
\end{tabular}

MULTIVARIATE TEST STATISTICS

\begin{tabular}{|c|c|c|c|c|c|c|}
\hline WILKS' LAMBDA - & 0.597 & & & & & \\
\hline F-STATISTIC $=$ & 10.578 & $D F=$ & 3, & 47 & QROB $=$ & 0.000 \\
\hline PILLAI TRACE - & 0.403 & & & & & \\
\hline F-STATISTIC - & 10.578 & $\mathrm{DF}=$ & 3, & 47 & PROB = & 0.000 \\
\hline ;-LAWLEY TRACE & 0.675 & & & & & \\
\hline F-STATISTIC & 10.578 & $\mathrm{DF}=$ & 3, & 47 & PROB - & 0.000 \\
\hline
\end{tabular}

15 CASES DELETED DUE TO MISSING DATA. NUMBER OE CASES PROCESSED: 50

DEPENDENT VARIABLE MEANS

$\operatorname{DESN}(9) \operatorname{COST}(26) \operatorname{TIME}(43) \operatorname{COMM}(60)$




\begin{tabular}{lllll} 
& 3.360 & 2.940 & 3.020 & 3.340 \\
REGRESSION COEFEICIENTS $B=\left(X^{\prime} X\right)$ & \multicolumn{1}{c}{$X^{\prime} Y$} & & \\
\\
DESN (9) & $\operatorname{COST}(26)$ & $\operatorname{TIME}(43)$ & $\operatorname{COMM}(60)$ \\
CONSTANT & 3.360 & 2.940 & 3.020 & 3.340
\end{tabular}

MULTIPLE CORRELATIONS

$\operatorname{DESN}(9) \quad \operatorname{COST}(26) \quad \operatorname{TIME}(43) \quad \operatorname{COMM}(60)$

$\begin{array}{llll}0.000 & 0.000 & 0.000 & 0.000\end{array}$

HYPOTHESIS.

C MATRIX

1

2

3

4

1

1.000

$-1.000$

0.000

0.000 


\begin{tabular}{|c|c|c|c|c|c|c|c|c|c|c|c|}
\hline \multirow{2}{*}{\multicolumn{2}{|c|}{$\begin{array}{l}2 \\
3\end{array}$}} & \multicolumn{3}{|c|}{0.000} & \multicolumn{3}{|c|}{1.000} & \multicolumn{2}{|c|}{-1.000} & \multicolumn{2}{|l|}{0.000} \\
\hline & & \multicolumn{3}{|c|}{0.000} & \multicolumn{3}{|c|}{0.000} & \multicolumn{2}{|c|}{1.000} & \multicolumn{2}{|l|}{-2.000} \\
\hline UNIVARIATE $F$ & TESTS & & & : & & & & & & & \\
\hline VARIABLE & & ss & & DE & & is & & & $\mathbf{F}$ & & $\mathrm{P}$ \\
\hline 1 & & 8.820 & & 1 & & 8.820 & & & 10.756 & & 0.002 \\
\hline ERROR & & 40.180 & & 49 & & 0.820 & & & & & \\
\hline 2 & & 0.320 & & 1 & & 0.320 & & & 0.797 & & 0.376 \\
\hline ERROR & & 19.680 & & 49 & & 0.402 & & & & & \\
\hline 3 & & 5.120 & & 1 & & 5.120 & & & 8.124 & & 0.006 \\
\hline ERROR & & 30.880 & & 49 & & 0.630 & & & & & \\
\hline \multirow[t]{5}{*}{ MULTIVARIATE } & TEST & STATIST & SICS & $i$ & & & & & & & \\
\hline & ILKS' & LAMBDA & $=$ & ' & 0.755 & & & & & & \\
\hline & F-STA & IrIstic & $=$ & । & 5.070 & $\mathrm{DF}$ & $=$ & 3 & 47 & PROB - & 0.004 \\
\hline & PILLAI & TRACE & : & । & 0.245 & & & & & & \\
\hline & E-STA & TISTIC & $=$ & । & 5.070 & $\mathrm{DF}$ & $=$ & 3 , & 47 & PROB = & 0.004 \\
\hline HOTELLING-I & LAWLEY & TRACE & $=$ & । & 0.324 & & & & & & \\
\hline & E-STA & IISTIC & - & । & 5.070 & $\mathrm{DF}$ & $=$ & 3, & 47 & PROB = & 0.004 \\
\hline
\end{tabular}

15 CASES DELETED DUE TO MISSING DATA.

NUMBER OE CASES PRDCESSED: 50

DEPENDENT VARIABLE MEANS

$\operatorname{DESN}(10) \operatorname{COST}(27) \quad \operatorname{TIME}(44) \quad \operatorname{COMM}(61)$ 


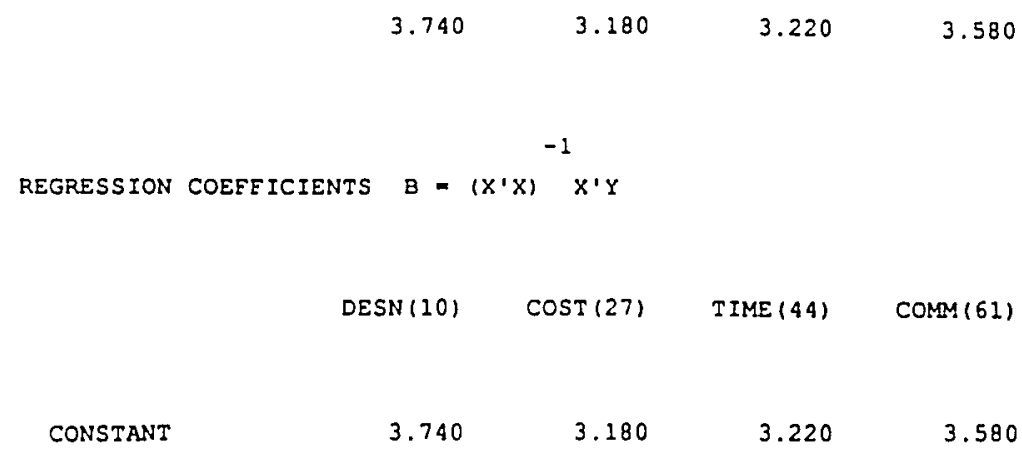

$\begin{array}{rrrr}1.000 & -1.000 & 0.000 & 0.000 \\ 0.000 & 1.000 & -1.000 & 0.000\end{array}$


3

0.000

0.000

1.000

$-1.000$

UNIVARIATE F TESTS

VARIABLE

1
ERROR
2
ERROR
3
ERROR

ss

$\begin{array}{rr}15.680 & 1 \\ 54.320 & 49 \\ 0.080 & 1 \\ 41.920 & 49 \\ 6.480 & 1 \\ 63.520 & 49\end{array}$

MS

15.680

1.109

0.080

0.856

6.480

1.296
E

14.144

0.094

4.999

MULTIVARIATE TEST STATISTICS

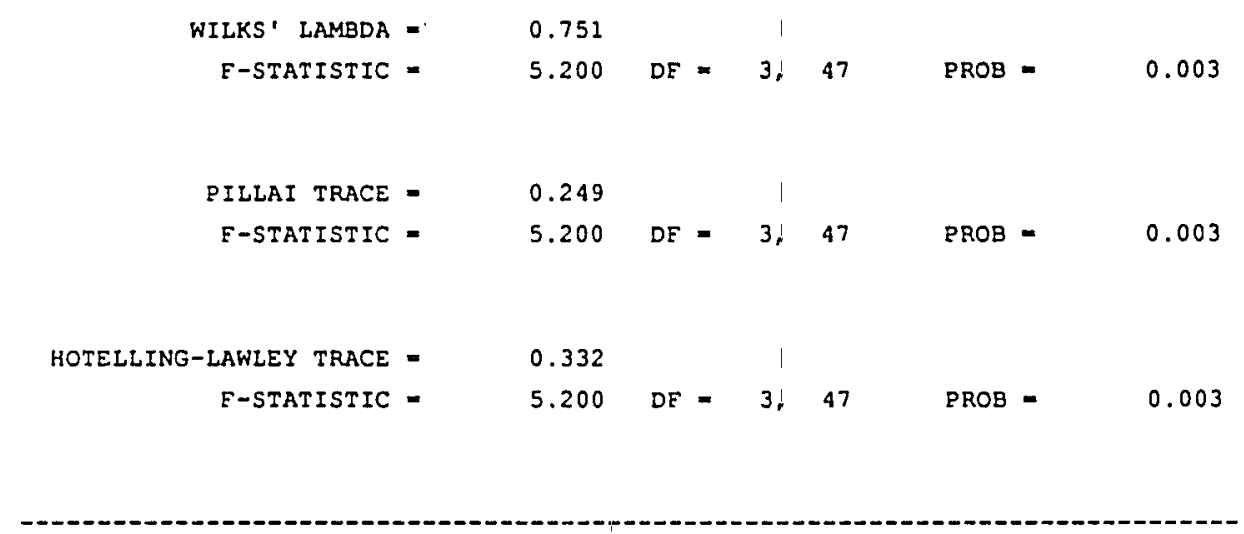

17 CASES DELETED DUE TO MISSING DATA. NUMBER OF CASES PROCESSED: 48

DEPENDENT VARIABLE MEANS

$$
\operatorname{DESN}(11) \operatorname{COST}(28) \quad \operatorname{TIME}(45) \quad \operatorname{COMM}(62)
$$




$\begin{array}{lllll}3.208 & 3.042 & 3.146 & 3.333 \\ \text { REGRESSION COEFEICIENTS } B=\left(X^{\prime} X\right)^{-1} \quad X^{\prime} Y & & \\ \\ \text { DESN(11) } & \operatorname{COST}(28) & \operatorname{TIME}(45) & \operatorname{COMM}(62) \\ \text { CONSTANT } & 3.208 & 3.042 & 3.146 & 3.333\end{array}$

MULTIPLE CORRELATIONS

$\begin{array}{rrrr}\operatorname{DESN}(11) & \operatorname{COST}(28) & \operatorname{TIME}(45) & \operatorname{COMM}(62) \\ 0.000 & 0.000 & 0.000 & 0.000\end{array}$

HYPOTHESIS.

C MATRIX

$\begin{array}{rrrrr} & 1 & 2 & 3 & 4 \\ 1 & 1.000 & -1.000 & 0.000 & 0.000 \\ 3 & 0.000 & 1.000 & -1.000 & 0.000 \\ & 0.000 & 0.000 & 1.000 & -1.000\end{array}$


UNIVARIATE F TESTS

\begin{tabular}{rrrlll} 
VARIABLE & \multicolumn{1}{l}{ SS } & DF & MS & P \\
& & & & & \\
1 & 1.333 & 1 & 1.333 & 2.541 & 0.118 \\
ERROR & 24.667 & 47 & 0.525 & & \\
2 & 0.521 & 1 & 0.521 & 1.962 & 0.168 \\
ERROR & 12.479 & 47 & 0.266 & & 0.071 \\
3 & 1.687 & 1 & 1.687 & 3.402 &
\end{tabular}

MULTIVARIATE TEST STATISTICS

\begin{tabular}{|c|c|c|c|c|c|c|c|c|c|}
\hline WILKS' LAMBDA & $=$ & 0.874 & & & & & & & \\
\hline E-STATISTIC & $=$ & 2.154 & $\mathrm{DE}$ & $=$ & 3, & 45 & PROB & - & 0.107 \\
\hline PILLAI TRACE & $=$ & 0.126 & & & & & & & \\
\hline E-STATISTIC & $=$ & 2.154 & $\mathrm{DF}$ & - & 3. & 45 & PROB - & - & 0.107 \\
\hline HOTELLING-IAWLEY TRACE & $=$ & 0.144 & & & & & & & \\
\hline F-STATISTIC & $=$ & 2.154 & $\mathrm{DE}$ & $=$ & 3, & 45 & PROB - & - & 0.107 \\
\hline
\end{tabular}

18 CASES DELETED DUE TO MISSING DATA.

NUMBER OF CASES PROCESSED: 47

DEPENDENT VARIABLE MEANS

$\begin{array}{rrrr}\operatorname{DESN}(12) & \operatorname{COST}(29) & \operatorname{TIME}(46) & \operatorname{COM}(63) \\ 3.000 & 2.872 & 3.021 & 3.043\end{array}$




\begin{tabular}{|c|c|c|c|c|}
\hline \multirow[b]{2}{*}{ REGRESSION } & \multicolumn{4}{|c|}{-1} \\
\hline & COEFEICIENTS $B=$ & $X) \quad X ' Y$ & & \\
\hline & $\operatorname{DESN}(12)$ & $\operatorname{cosT}(29)$ & $\operatorname{TIME}(46)$ & $\operatorname{COM} M(63)$ \\
\hline CONSTANT & 3.000 & 2.872 & 3.021 & 3.043 \\
\hline
\end{tabular}

MULTIPLE CORRELATIONS

$\operatorname{DESN}(12) \quad \operatorname{COST}(29) \quad \operatorname{TIME}(46) \quad \operatorname{COMM}(63)$
0.000
0.000
0.000
0.000

HYPOTHESIS.

C MATRIX

2

3

4

$\begin{array}{rrrrr}1 & 1.000 & -1.000 & 0.000 & 0.000 \\ 2 & 0.000 & 1.000 & -1.000 & 0.000 \\ 3 & 0.000 & 0.000 & 1.000 & -1.000\end{array}$


UNIVARIATE E TESTS

VARIABLE

ss

DF

MS

0.766

0.809

1.043

0.695

0.021

1.065

$48.979 \quad 46$

ERROR

46

$\mathbf{F}$

0.946

1.501

0.020

MULTIVARIATE TEST STATISTICS

\begin{tabular}{|c|c|c|c|c|c|c|c|}
\hline \multirow{2}{*}{\multicolumn{2}{|c|}{$\begin{array}{r}\text { WILKS LAMBDA = } \\
\text { F-STATISTIC = }\end{array}$}} & \multirow{2}{*}{$\begin{array}{l}0.946 \\
0.841\end{array}$} & \multirow[b]{2}{*}{$D F=$} & \multirow[b]{2}{*}{3} & \multirow[b]{2}{*}{44} & \multirow[b]{2}{*}{ PROB = } & \multirow[b]{2}{*}{0.479} \\
\hline & & & & & & & \\
\hline PILLAI TRACE & $=$ & 0.054 & & & & & \\
\hline E-STATISTIC & $=$ & 0.841 & $D F=$ & 3, & 44 & PROB $=$ & 0.479 \\
\hline HOTELLING-LAWLEY TRACE & $=$ & 0.057 & & & & & \\
\hline F-STATISTIC & $=$ & 0.841 & $D E=$ & 3, & 44 & PROB = & 0.479 \\
\hline
\end{tabular}

16 CASES DELETED DUE TO MISSING DATA.

NUMBER OF CASES PROCESSED:

49

DEPENDENT VARIABLE MEANS

$\begin{array}{rrrr}\operatorname{DESN}(13) & \operatorname{COST}(30) & \operatorname{TIME}(47) & \operatorname{COM}(64) . \\ 3.429 & 3.204 & 3.306 & 3.633\end{array}$




\begin{tabular}{|c|c|c|c|c|}
\hline REGRESSION & NTS B = & $x)^{-1} x \cdot y$ & & \\
\hline & $\operatorname{DESN}(13)$ & $\cos T(30)$ & $\operatorname{TIME}(47)$ & $\operatorname{COMM}(64)$ \\
\hline CONSTANT & 3.429 & 3.204 & 3.306 & 3.633 \\
\hline
\end{tabular}

MULTIPLE CORRELATIONS

DESN (13) COST (30) TIME (47) COMM(64)

$\begin{array}{llll}0.000 & 0.000 & 0.000 & 0.000\end{array}$

HYPOTHESIS.

C MATRIX

2

4

$\begin{array}{rrrrr}1 & 1.000 & -1.000 & 0.000 & 0.000^{\circ} \\ 2 & 0.000 & 1.000 & -1.000 & 0.000 \\ 3 & 0.000 & 0.000 & 1.000 & -1.000\end{array}$


UNIVARIATE E TESTS

\begin{tabular}{rrrlll} 
VARIABLE & \multicolumn{1}{l}{ SS } & DE & \multicolumn{1}{l}{ MS } & F & P \\
& & & & & \\
1 & 2.469 & 1 & 2.469 & 2.442 & 0.125 \\
ERROR & 48.531 & 48 & 1.011 & & \\
2 & 0.510 & 1 & 0.510 & 0.860 & 0.358 \\
ERROR & 28.490 & 48 & 0.594 & & \\
3 & 5.224 & 1 & 5.224 & 7.211 & 0.010 \\
ERROR & 34.776 & 48 & 0.724 & &
\end{tabular}

MULTIVARIATE IEST STATISTICS

\begin{tabular}{|c|c|c|c|c|c|c|}
\hline WILKS' LAMBDA = & 0.809 & & & & & \\
\hline E-STATISTIC $=$ & 3.609 & $D E=$ & 3, & 46 & PROB = & 0.020 \\
\hline PILLAI TRACE = & 0.191 & & & & & \\
\hline E-STATISTIC $=$ & 3.609 & $D F=$ & 3, & 46 & PROB - & 0.020 \\
\hline HOTELIING-LAWLEY TRACE & 0.235 & & & & & \\
\hline F-STATISTIC - & 3.609 & $D E$ & 3, & 46 & PROB = & 0.020 \\
\hline
\end{tabular}

16 CASES DELETED DUE TO MISSING DATA.

NUMBER OF CASES PROCESSED:

49

DEPENDENT VARIABLE MEANS

$\begin{array}{rrrr}\operatorname{DESN}(14) & \operatorname{COST}(31) & \operatorname{TIME}(48) & \operatorname{COMM}(65) . \\ 3.735 & 3.429 & 3.449 & 3.592\end{array}$




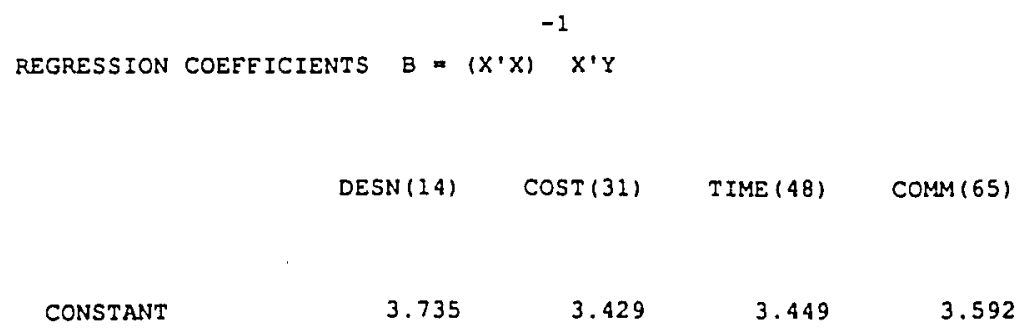

MUITIPLE CORRELATIONS

$\begin{array}{rrrr}\operatorname{DESN}(14) & \operatorname{COST}(31) & \operatorname{TIME}(48) & \operatorname{COMM}(65) \\ 0.000 & 0.000 & 0.000 & 0.000\end{array}$

HYPOTHESIS.

C MATRIX

2

3

4

$\begin{array}{rrrrr}1 & 1.000 & -1.000 & 0.000 & 0.000 \\ 2 & 0.000 & 1.000 & -1.000 & 0.000 \\ 3 & 0.000 & 0.000 & 1.000 & -1.000\end{array}$

UNIVARIATE E TESTS 


\begin{tabular}{rrrlll} 
VARIABLE & \multicolumn{1}{l}{ SS } & DF & MS & F & P \\
& & & & & \\
ERROR & 34.408 & 48 & 0.717 & 6.406 & 0.015 \\
2 & 0.020 & 1 & 0.020 & 0.058 & 0.811 \\
ERROR & 16.980 & 48 & 0.354 & & \\
3 & 1.000 & 1 & 1.000 & 1.714 & 0.197 \\
ERROR & 28.000 & 48 & 0.583 & &
\end{tabular}

MULTIVARIATE TEST STATISTICS

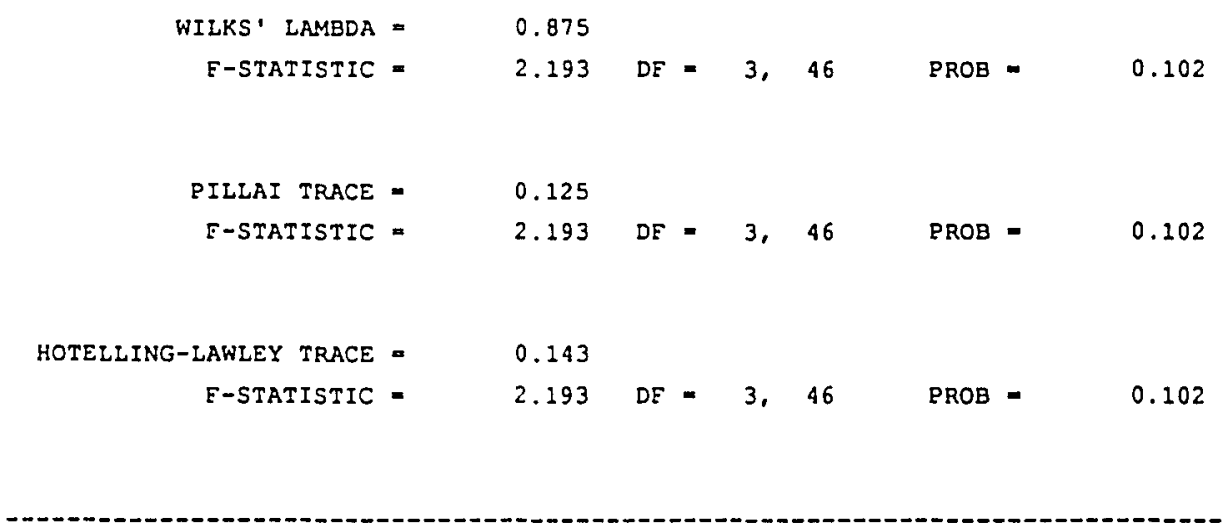

16 CASES DELETED DUE TO MISSING DATA.

NUMBER OF CASES PROCESSED: 49

DEPENDENT VARIABLE MEANS

$\begin{array}{rrrr}\operatorname{DESN}(15) & \operatorname{COST}(32) & \operatorname{TIME}(49) & \operatorname{COMM}(66) \\ & & & . \\ 3.571 & 3.306 & 3.306 & 3.694\end{array}$


REGRESSION COEFEICIENTS $B=\left(X^{\prime} X\right) \quad X^{\prime} Y$

$$
\operatorname{DESN}(15) \quad \operatorname{COST}(32) \quad \operatorname{TIME}(49) \quad \operatorname{COMM}(66)
$$

$\begin{array}{lllll}\text { CONSTANT } & 3.571 & 3.306 & 3.306 & 3.594\end{array}$

MULTIPLE CORRELATIONS

$\begin{array}{rrrr}\operatorname{DESN}(15) & \operatorname{COST}(32) & \operatorname{TIME}(49) & \operatorname{COMM}(66) \\ 0.000 & 0.000 & 0.000 & 0.000\end{array}$

HYPOTHESIS.

C MATRIX

\begin{tabular}{rrrrr} 
& 1 & \multicolumn{1}{l}{2} & \multicolumn{1}{l}{3} & \multicolumn{1}{l}{4} \\
1 & 1.000 & -1.000 & 0.000 & 0.000 \\
2 & 0.000 & 1.000 & -1.000 & 0.000 \\
3 & 0.000 & 0.000 & 1.000 & -1.000
\end{tabular}

UNIVARIATE E TESTS 


\begin{tabular}{rrrlll} 
VARIABLE & \multicolumn{1}{l}{ SS } & DE & MS & F & P \\
& & & & & \\
1 & 3.449 & 1 & 3.449 & 3.801 & 0.057 \\
ERROR & 43.551 & 48 & 0.907 & & \\
2 & 0.000 & 1 & 0.000 & 0.000 & 1.000 \\
ERROR & 22.000 & 48 & 0.458 & & \\
3 & 7.367 & 1 & 7.367 & 11.934 & 0.001 \\
ERROR & 29.633 & 48 & 0.617 & &
\end{tabular}

MULTIVARIATE TEST STATISTICS

\begin{tabular}{|c|c|c|c|c|c|c|}
\hline WILKS' LAMBDA = & 0.792 & & & & & \\
\hline F-STATISTIC $=$ & 4.036 & $D F=$ & 3, & 46 & PROB = & 0.012 \\
\hline PILLAI TRACE = & 0.208 & & & & & \\
\hline F-STATISTIC & 4.036 & $D F=$ & 3, & 46 & PROB = & 0.012 \\
\hline HOTELLING-LAWLEY TRACE - & 0.263 & & & & & \\
\hline E-STATISTIC & 4.036 & $D F=$ & 3. & 46 & PROB = & 0.012 \\
\hline
\end{tabular}

17 CASES DELETED DUE TO MISSING DATA. NUMBER OF CASES PROCESSED: 48

DEPENDENT VARIABLE MEANS

$\begin{array}{lrrr}\operatorname{DESN}(16) & \operatorname{COST}(33) & \operatorname{TIME}(50) & \operatorname{COMM}(67) \\ 3.250 & 3.104 & 3.292 & 3: 354 \\ & \\ & \\ & \\ & \\ & \end{array}$




$\begin{array}{rrrrr} & \operatorname{DESN}(16) & \operatorname{COST}(33) & \operatorname{TIME}(50) & \operatorname{COMM}(67) \\ \text { CONSTANT } & 3.250 & 3.104 & 3.292 & 3.354\end{array}$

MULTIPLE CORRELATIONS

$\begin{array}{rrrr}\operatorname{DESN}(16) & \operatorname{COST}(33) & \operatorname{TIME}(50) & \operatorname{COM}(67) \\ 0.000 & 0.000 & 0.000 & 0.000\end{array}$

HYPOTHESIS.

C MATRIX

1

2

1. 000

0.000

0.000
-1.000
1.000

0.000
3

0.000

$-1.000$

1.000
0.000

0.000

$-1.000$

UNIVARIATE F TESTS 


\begin{tabular}{rrrlll} 
VARTABLE & SS & DF & \multicolumn{1}{l}{ MS } & F & P \\
& & & & & \\
ERROR & 43.979 & 47 & 0.936 & 1.091 & 0.302 \\
2 & 1.687 & 1 & 1.687 & 5.180 & 0.027 \\
ERROR & 15.313 & 47 & 0.326 & & \\
3 & 0.188 & 1 & 0.188 & 0.306 & 0.583 \\
ERROR & 28.813 & 47 & 0.613 & &
\end{tabular}

MULTIVARIATE TEST STATISTICS

\begin{tabular}{|c|c|c|c|c|c|c|}
\hline WILKS' LAMBDA $=$ & 0.974 & & & & & \\
\hline F-STATISTIC $=$ & 2.160 & $\mathrm{DF}=$ & 3, & 45 & PROB = & 0.106 \\
\hline PILLAI TRACE = & 0.126 & & & & & \\
\hline E-STATISTIC $=$ & 2.160 & $D E=$ & 3. & 45 & PROB - & 0.106 \\
\hline HOTELLING-LAWLEY TRACE - & 0.144 & & & & & \\
\hline F-STATISTIC - & 2.160 & $D F=$ & 3, & 45 & PROB = & 0.106 \\
\hline
\end{tabular}

16 CASES DELETED DUE TO MISSING DATA. NUMBER OF CASES PROCESSED: 49

DEPENDENT VARIABLE MEANS

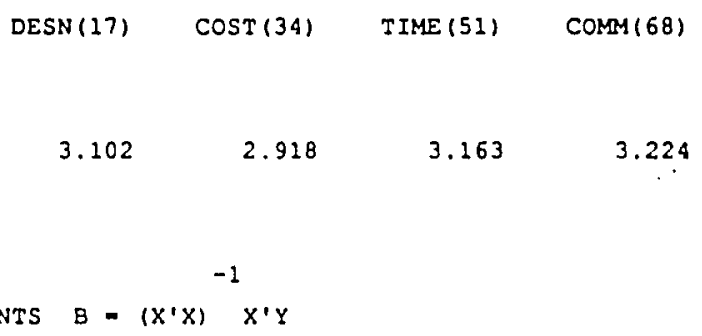


$\operatorname{DESN}(17) \operatorname{COST}(34) \quad \operatorname{TIME}(51) \quad \operatorname{COM}(68)$

$\begin{array}{lllll}\text { CONSTANT } & 3.102 & 2.918 & 3.163 & 3.224\end{array}$

MULTIPLE CORRELATIONS

$\begin{array}{rrrr}\operatorname{DESN}(17) & \operatorname{COST}(34) & \operatorname{TIME}(51) & \operatorname{COMM}(68) \\ 0.000 & 0.000 & 0.000 & 0.000\end{array}$

HYPOTHESIS.

C MATRIX

1

2

3

4

$\begin{array}{rrrrr}1 & 1.000 & -1.000 & 0.000 & 0.000 \\ 2 & 0.000 & 1.000 & -1.000 & 0.000 \\ 3 & 0.000 & 0.000 & 1.000 & -1.000\end{array}$

UNIVARIATE F TESTS

VARIABLE

ss

DE

MS

F 


$\begin{array}{rrrrrr}1 & 1.653 & 1 & 1.653 & 1.144 & 0.290 \\ \text { ERROR } & 69.347 & 48 & 1.445 & & \\ 2 & 2.939 & 1 & 2.939 & 3.276 & 0.077 \\ \text { ERROR } & 43.061 & 48 & 0.897 & & \\ 3 & 0.184 & 1 & 0.184 & 0.239 & 0.627 \\ \text { ERROR } & 36.816 & 48 & 0.767 & & \end{array}$

MULTIVARIATE TEST STATISTICS

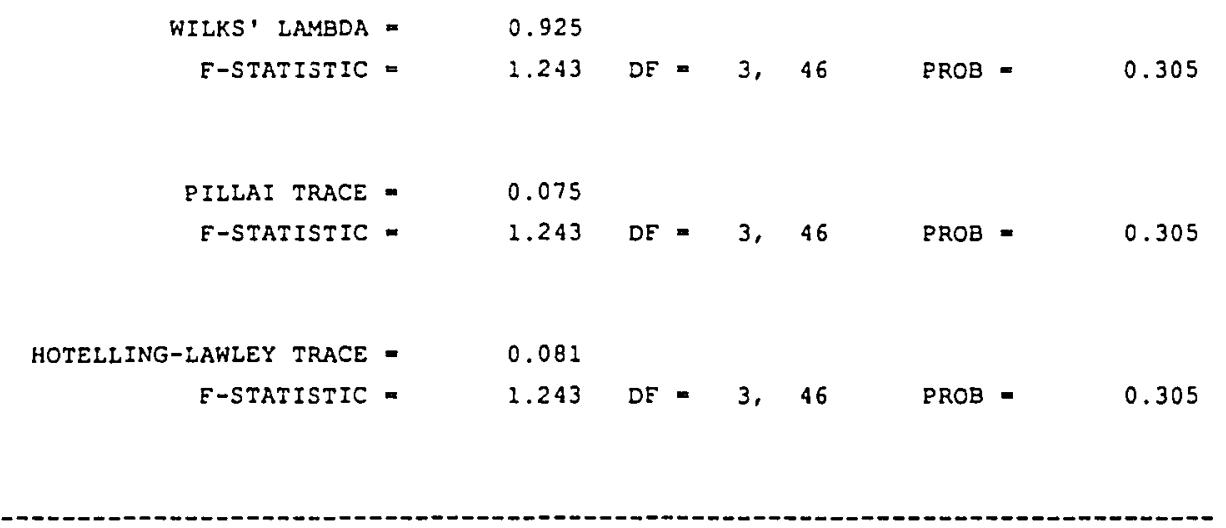


14 CASES DELETED DUE TO MISSING DATA. NUMBER OF CASES PROCESSED: 51

DEPENDENT VARIABLE MEANS

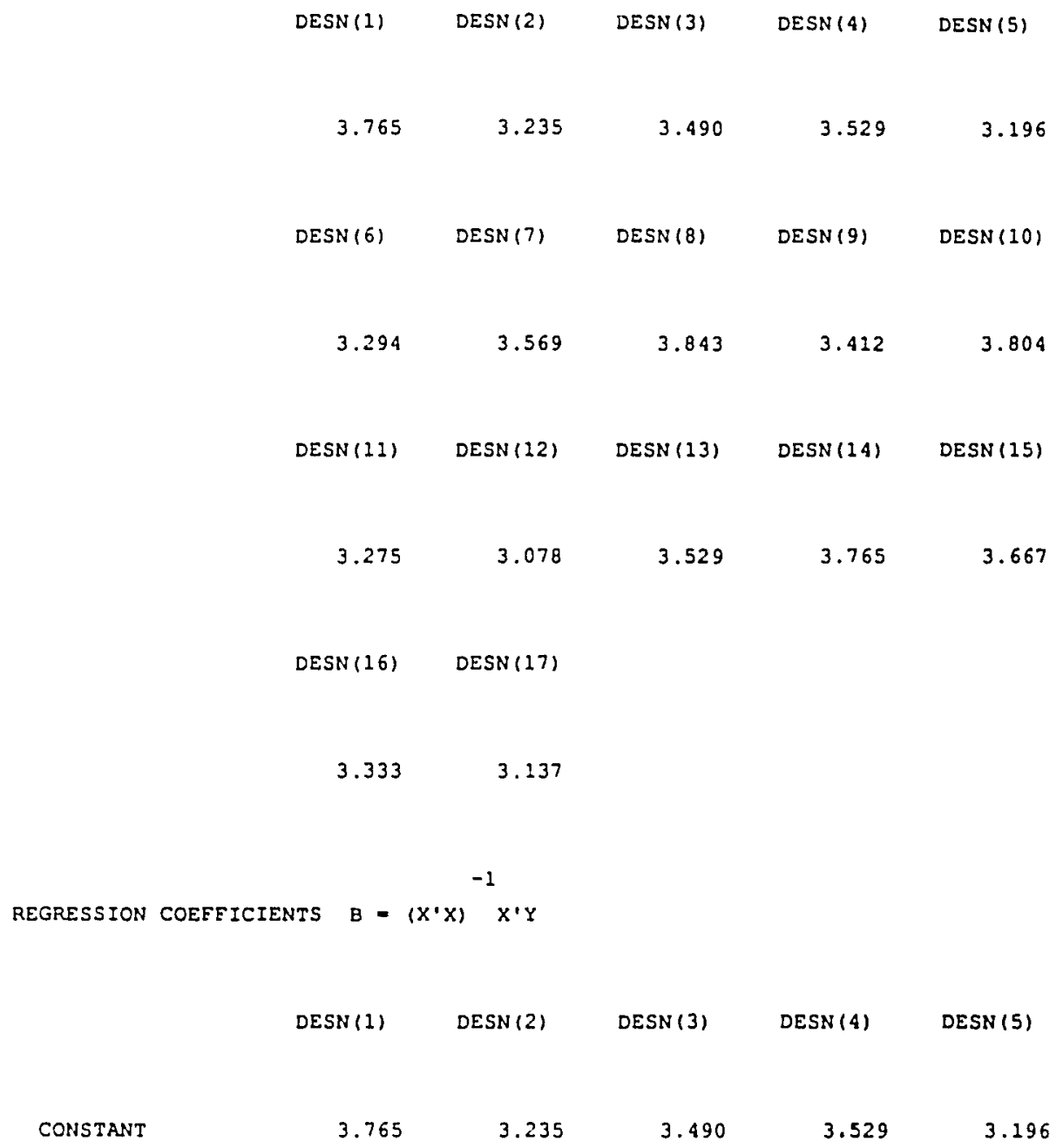




$\begin{array}{rrrrrr} & \operatorname{DESN}(6) & \operatorname{DESN}(7) & \operatorname{DESN}(9) & \operatorname{DESN}(9) & \operatorname{DESN}(10) \\ \text { CONSTANT } & 3.294 & 3.569 & 3.843 & 3.412 & 3.904\end{array}$

CONSTANT

3.275

$\operatorname{DESN}(12)$

$\operatorname{DESN}(13)$

DESN (14)

DESN (15)

DESN (11)

DESN(12)

Desn (13)

(2)

(2)

3.078

3.529

3.765

3.667

$\operatorname{DESN}(16)$

DESN (17)

CONSTANT
3.333

3.137

MULTIPLE CORRELATIONS

$\begin{array}{rrrrr}\operatorname{DESN}(1) & \operatorname{DESN}(2) & \operatorname{DESN}(3) & \operatorname{DESN}(4) & \operatorname{DESN}(5) \\ 0.000 & 0.000 & 0.000 & 0.000 & 0.000 \\ \operatorname{DESN}(6) & \operatorname{DESN}(7) & \operatorname{DESN}(8) & \operatorname{DESN}(9) & \operatorname{DESN}(10) \\ 0.000 & 0.000 & 0.000 & 0.000 & 0.000 \\ & & & & \\ \operatorname{DESN}(11) & \operatorname{DESN}(12) & \operatorname{DESN}(13) & \operatorname{DESN}(14) & \operatorname{DESN}(15)\end{array}$


$\begin{array}{lllll}0.000 & 0.000 & 0.000 & 0.000 & 0.000\end{array}$

DESN (16) DESN (17)

$0.000 \quad 0.000$

HYPOTHESIS .

C MATRIX

1.000

0.000

0.000

0.000

0.000

0.000

0.000

0.000

0.000

0.000

0.000

0.000

0.000

0.000

0.000

0.000

6
2

$-1.000$

1.000

0.000

0.000

0.000

0.000

0.000

0.000

0.000

0.000

0.000

0.000

0.000

0.000

0.000

0.000

7
3

4

$\begin{array}{rrr}0.000 & 0.000 & 0.000 \\ -1.000 & 0.000 & 0.000 \\ 1.000 & -1.000 & 0.000 \\ 0.000 & 1.000 & -1.000 \\ 0.000 & 0.000 & 1.000 \\ 0.000 & 0.000 & 0.000 \\ 0.000 & 0.000 & 0.000 \\ 0.000 & 0.000 & 0.000 \\ 0.000 & 0.000 & 0.000 \\ 0.000 & 0.000 & 0.000 \\ 0.000 & 0.000 & 0.000 \\ 0.000 & 0.000 & 0.000 \\ 0.000 & 0.000 & 0.000 \\ 0.000 & 0.000 & 0.000 \\ 0.000 & 0.000 & 0.000 \\ 0.000 & 0.000 & 0.000\end{array}$

8

9

10 


$\begin{array}{rrrrr}0.000 & 0.000 & 0.000 & 0.000 & 0.000 \\ 0.000 & 0.000 & 0.000 & 0.000 & 0.000 \\ 0.000 & 0.000 & 0.000 & 0.000 & 0.000 \\ 0.000 & 0.000 & 0.000 & 0.000 & 0.000 \\ -1.000 & 0.000 & 0.000 & 0.000 & 0.000 \\ 1.000 & -1.000 & 0.000 & 0.000 & 0.000 \\ 0.000 & 1.000 & -1.000 & 0.000 & 0.000 \\ 0.000 & 0.000 & 1.000 & -1.000 & 0.000 \\ 0.000 & 0.000 & 0.000 & 1.000 & -1.000 \\ 0.000 & 0.000 & 0.000 & 0.000 & 1.000 \\ 0.000 & 0.000 & 0.000 & 0.000 & 0.000 \\ 0.000 & 0.000 & 0.000 & 0.000 & 0.000 \\ 0.000 & 0.000 & 0.000 & 0.000 & 0.000 \\ 0.000 & 0.000 & 0.000 & 0.000 & 0.000 \\ 0.000 & 0.000 & 0.000 & 0.000 & 0.000 \\ 0.000 & 0.000 & 0.000 & 0.000 & 0.000\end{array}$

$\begin{array}{rrrrr}0.000 & 0.000 & 0.000 & 0.000 & 0.000 \\ 0.000 & 0.000 & 0.000 & 0.000 & 0.000 \\ 0.000 & 0.000 & 0.000 & 0.000 & 0.000 \\ 0.000 & 0.000 & 0.000 & 0.000 & 0.000 \\ 0.000 & 0.000 & 0.000 & 0.000 & 0.000 \\ 0.000 & 0.000 & 0.000 & 0.000 & 0.000 \\ 0.000 & 0.000 & 0.000 & 0.000 & 0.000 \\ 0.000 & 0.000 & 0.000 & 0.000 & 0.000 \\ 0.000 & 0.000 & 0.000 & 0.000 & 0.000 \\ -1.000 & 0.000 & 0.000 & 0.000 & 0.000 \\ 1.000 & -1.000 & 0.000 & 0.000 & 0.000 \\ 0.000 & 1.000 & -1.000 & 0.000 & 0.000 \\ 0.000 & 0.000 & 1.000 & -1.000 & 0.000 \\ 0.000 & 0.000 & 0.000 & 1.000 & -1.000 \\ 0.000 & 0.000 & 0.000 & 0.000 & 1.000 \\ 0.000 & 0.000 & 0.000 & 0.000 & 0.000\end{array}$




$\begin{array}{rrr}1 & 0.000 & 0.000 \\ 2 & 0.000 & 0.000 \\ 3 & 0.000 & 0.000 \\ 4 & 0.000 & 0.000 \\ 5 & 0.000 & 0.000 \\ 6 & 0.000 & 0.000 \\ 7 & 0.000 & 0.000 \\ 8 & 0.000 & 0.000 \\ 9 & 0.000 & 0.000 \\ 10 & 0.000 & 0.000 \\ 11 & 0.000 & 0.000 \\ 12 & 0.000 & 0.000 \\ 13 & 0.000 & 0.000 \\ 14 & 0.000 & 0.000 \\ 15 & -1.000 & 0.000 \\ 16 & 1.000 & -1.000\end{array}$

UNIVARIATE F TESTS

\begin{tabular}{|c|c|c|c|c|c|}
\hline VARIABLE & ss & $\mathrm{DF}$ & MS & $E$ & P \\
\hline 1 & 14.294 & 1 & 14.294 & 18.465 & 0.000 \\
\hline ERROR & 38.706 & 50 & 0.774 & & \\
\hline 2 & 3.314 & 1 & 3.314 & 1.890 & 0.175 \\
\hline ERROR & 87.686 & 50 & 1.754 & & \\
\hline 3 & 0.078 & 1 & 0.078 & 0.094 & 0.761 \\
\hline ERROR & 41.922 & 50 & 0.838 & & \\
\hline 4 & 5.667 & 1 & 5.667 & 4.337 & 0.042 \\
\hline ERROR & 65.333 & so & 1.307 & & \\
\hline 5 & 0.490 & 1 & 0.490 & 0.304 & 0.584 \\
\hline ERROR & 80.510 & 50 & 1.610 & & \\
\hline 6 & 3.843 & 1 & 3.843 & 3.990 & 0.051 \\
\hline ERROR & 48.157 & 50 & 0.963 & & \\
\hline 7 & 3.843 & 1 & 3.843 & 5.315 & 0.025 \\
\hline ERROR & 36.157 & 50 & 0.723 & & \\
\hline 8 & 9.490 & 1 & 9.490 & 13.750 & 0.001 \\
\hline ERROR & 34.510 & 50 & 0.690 & & \\
\hline 9 & 7.843 & 1 & 7.843 & 14.993 & 0.000 \\
\hline ERROR & 26.157 & 50 & 0.523 & & \\
\hline
\end{tabular}




$\begin{array}{rrrrrr}10 & 14.294 & 1 & 14.294 & 15.987 & 0.000 \\ \text { ERROR } & 44.706 & 50 & 0.894 & & \\ 11 & 1.961 & 1 & 1.961 & 2.332 & 0.133 \\ \text { ERROR } & 42.039 & 50 & 0.841 & & \\ 12 & 10.373 & 1 & 10.373 & 10.244 & 0.002 \\ \text { ERROR } & 50.627 & 50 & 1.013 & & \\ 13 & 2.824 & 1 & 2.824 & 4.528 & 0.038 \\ \text { ERROR } & 31.176 & 50 & 0.624 & & \\ 14 & 0.490 & 1 & 0.490 & 0.434 & 0.513 \\ \text { ERROR } & 56.510 & 50 & 1.130 & & \\ 15 & 5.667 & 1 & 5.667 & 4.620 & 0.036 \\ \text { ERROR } & 61.333 & 50 & 1.227 & & \\ 16 & 1.961 & 1 & 1.961 & 2.041 & 0.159 \\ \text { ERROR } & 48.039 & 50 & 0.961 & & \end{array}$

MULTIVARIATE TEST STATISTICS

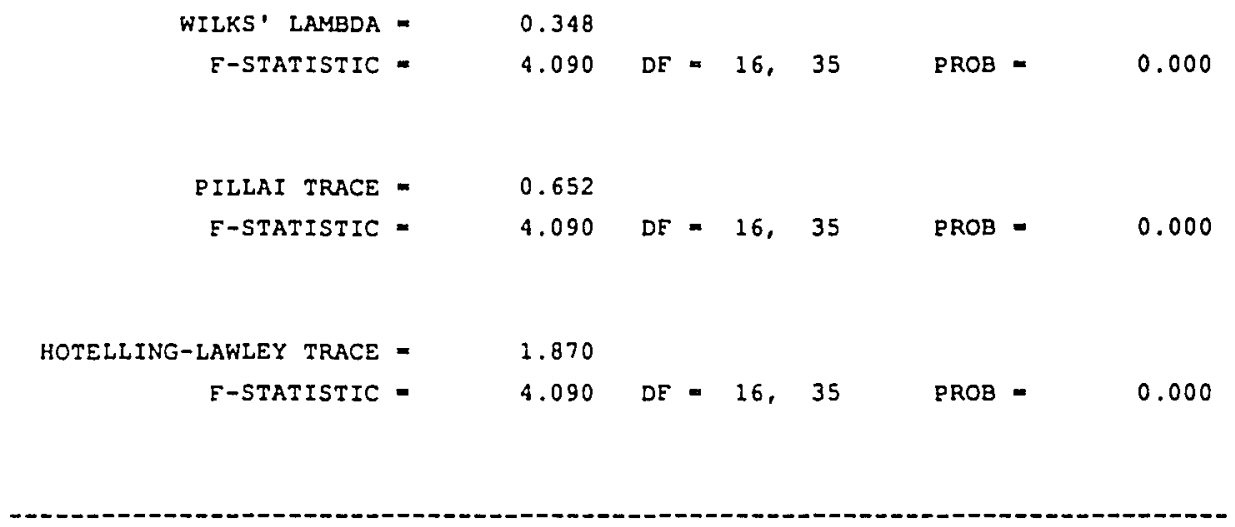

13 CASES DELETED DUE TO MISSING DATA.

NUMBER OF CASES PROCESSED: 52

DEPENDENT VARIABLE MEANS

$\begin{array}{rrrrr}\operatorname{cosT}(18) & \cos (19) & \cos 2(20) & \cos (21) & \operatorname{cosT}(22) \\ & & & & \\ 3.077 & 2.981 & 2.769 & 2.962 & 3.077\end{array}$




\begin{tabular}{|c|c|c|c|c|c|}
\hline & $\cos 2(23)$ & $\cos T(24)$ & $\cos T(25)$ & $\operatorname{cost}(26)$ & $\cos T(27)$ \\
\hline & 3.058 & 3.058 & 3.212 & 2.962 & 3.212 \\
\hline & $\cos T(28)$ & $\cos T(29)$ & $\cos T(30)$ & $\cos (31)$ & $\cos (32)$ \\
\hline & 3.077 & 2.865 & 3.173 & 3.423 & 3.308 \\
\hline & $\cos \pi(33)$ & $\cos T(34)$ & & & \\
\hline & 3.096 & 2.981 & & & \\
\hline & & -1 & & & \\
\hline REGRESSION & COEFEICIENTS $\quad \mathrm{B}=$ & $\left(X^{\prime} X\right) \quad X^{\prime} Y$ & & & \\
\hline & $\cos T(28)$ & $\cos (19)$ & $\cos t(20)$ & $\cos T(21)$ & $\cos T(22)$ \\
\hline CONSTANT & 3.077 & 2.981 & 2.769 & 2.962 & 3.077 \\
\hline & $\cos (23)$ & $\cos T(24)$ & $\cos T(25)$ & $\cos T(26)$ & $\cos 2(27)$ \\
\hline CONSTANT & 3.058 & 3.058 & 3.212 & 2.962 & 3.212 \\
\hline & $\cos T(28)$ & $\cos 2(29)$ & $\cos T(30)$ & $\cos T(31)$ & $\cos T(32)$ \\
\hline
\end{tabular}


CONSTANT

3.077

2.865

3.173

3.423

3.308

$\operatorname{cosT}(33) \quad \cos (34)$

CONSTANI

3.096

2.981

MULTIPLE CORRELATIONS

\begin{tabular}{|c|c|c|c|c|}
\hline $\cos T(18)$ & $\cos T(19)$ & $\operatorname{cosT}(20)$ & $\cos T(21)$ & $\cos T(22)$ \\
\hline 0.000 & 0.000 & 0.000 & 0.000 & 0.000 \\
\hline $\cos T(23)$ & $\cos T(24)$ & $\operatorname{cost}(25)$ & $\operatorname{cost}(26)$ & $\cos t(27)$ \\
\hline 0.000 & 0.000 & 0.000 & 0.000 & 0.000 \\
\hline $\operatorname{cosT}(28)$ & $\cos T(29)$ & $\cos T(30)$ & $\operatorname{cost}(31)$ & $\cos r(32)$ \\
\hline 0.000 & 0.000 & 0.000 & 0.000 & 0.000 \\
\hline $\cos 5(33)$ & $\cos T(34)$ & & & \\
\hline 0.000 & 0.000 & & & \\
\hline
\end{tabular}


HYPOTHES IS .

C MATRIX

1

2

3

$\begin{array}{rrrrr}1.000 & -1.000 & 0.000 & 0.000 & 0.000 \\ 0.000 & 1.000 & -1.000 & 0.000 & 0.000 \\ 0.000 & 0.000 & 1.000 & -1.000 & 0.000 \\ 0.000 & 0.000 & 0.000 & 1.000 & -1.000 \\ 0.000 & 0.000 & 0.000 & 0.000 & 1.000 \\ 0.000 & 0.000 & 0.000 & 0.000 & 0.000 \\ 0.000 & 0.000 & 0.000 & 0.000 & 0.000 \\ 0.000 & 0.000 & 0.000 & 0.000 & 0.000 \\ 0.000 & 0.000 & 0.000 & 0.000 & 0.000 \\ 0.000 & 0.000 & 0.000 & 0.000 & 0.000 \\ 0.000 & 0.000 & 0.000 & 0.000 & 0.000 \\ 0.000 & 0.000 & 0.000 & 0.000 & 0.000 \\ 0.000 & 0.000 & 0.000 & 0.000 & 0.000 \\ 0.000 & 0.000 & 0.000 & 0.000 & 0.000 \\ 0.000 & 0.000 & 0.000 & 0.000 & 0.000 \\ 0.000 & 0.000 & 0.000 & 0.000 & 0.000\end{array}$

6

7

8

9

10
0.000

0.000

0.000

0.000

0.000

$-1.000$

1.000

0.000

0.000

0.000
0.000

0.000

0.000

0.000

$-1.000$

1.000

0.000

0.000
0.000

0.000

0.000

0.000

0.000

0.000

$-1.000$

1.000

0.000
0.000

0.000

0.000

0.000

0.000

0.000

0.000

$-1.000$

1.000
0.000

0.000

0.000

0.000

0.000

0.000

0.000

0.000

$-1.000$ 


$\begin{array}{llllll}10 & 0.000 & 0.000 & 0.000 & 0.000 & 1.000 \\ 11 & 0.000 & 0.000 & 0.000 & 0.000 & 0.000 \\ 12 & 0.000 & 0.000 & 0.000 & 0.000 & 0.000 \\ 13 & 0.000 & 0.000 & 0.000 & 0.000 & 0.000 \\ 14 & 0.000 & 0.000 & 0.000 & 0.000 & 0.000 \\ 15 & 0.000 & 0.000 & 0.000 & 0.000 & 0.000 \\ 16 & 0.000 & 0.000 & 0.000 & 0.000 & 0.000\end{array}$

$\begin{array}{rrrrr}0.000 & 0.000 & 0.000 & 0.000 & 0.000 \\ 0.000 & 0.000 & 0.000 & 0.000 & 0.000 \\ 0.000 & 0.000 & 0.000 & 0.000 & 0.000 \\ 0.000 & 0.000 & 0.000 & 0.000 & 0.000 \\ 0.000 & 0.000 & 0.000 & 0.000 & 0.000 \\ 0.000 & 0.000 & 0.000 & 0.000 & 0.000 \\ 0.000 & 0.000 & 0.000 & 0.000 & 0.000 \\ 0.000 & 0.000 & 0.000 & 0.000 & 0.000 \\ 0.000 & 0.000 & 0.000 & 0.000 & 0.000 \\ -1.000 & 0.000 & 0.000 & 0.000 & 0.000 \\ 1.000 & -1.000 & 0.000 & 0.000 & 0.000 \\ 0.000 & 1.000 & -1.000 & 0.000 & 0.000 \\ 0.000 & 0.000 & 1.000 & -1.000 & 0.000 \\ 0.000 & 0.000 & 0.000 & 1.000 & -1.000 \\ 0.000 & 0.000 & 0.000 & 0.000 & 1.000 \\ 0.000 & 0.000 & 0.000 & 0.000 & 0.000\end{array}$

$\begin{array}{ll}0.000 & 0.000 \\ 0.000 & 0.000 \\ 0.000 & 0.000 \\ 0.000 & 0.000 \\ 0.000 & 0.000 \\ 0.000 & 0.000 \\ 0.000 & 0.000 \\ 0.000 & 0.000 \\ 0.000 & 0.000 \\ 0.000 & 0.000\end{array}$




$\begin{array}{rrr}11 & 0.000 & 0.000 \\ 12 & 0.000 & 0.000 \\ 13 & 0.000 & 0.000 \\ 14 & 0.000 & 0.000 \\ 15 & -1.000 & 0.000 \\ 16 & 1.000 & -1.000\end{array}$

UNIVARIATE F TESTS

\begin{tabular}{|c|c|c|c|c|c|}
\hline VARIABLE & ss & DE & MS & $\boldsymbol{F}$ & P \\
\hline 1 & 0.481 & 1 & 0.481 & 2.878 & 0.096 \\
\hline ERROR & 8.519 & 51 & 0.167 & & \\
\hline 2 & 2.327 & 1 & 2.327 & 3.423 & 0.070 \\
\hline ERROR & 34.673 & 51 & 0.680 & & \\
\hline 3 & 1.923 & 1 & 1.923 & 6.100 & 0.017 \\
\hline ERROR & 16.077 & 51 & 0.315 & & \\
\hline 4 & 0.692 & 1 & 0.692 & 1.128 & 0.293 \\
\hline ERROR & 31.308 & 51 & 0.614 & & \\
\hline 5 & 0.019 & 1 & 0.019 & 0.047 & 0.830 \\
\hline ERROR & 20.981 & 51 & 0.411 & & \\
\hline 6 & 0.000 & 1 & 0.000 & 0.000 & 1.000 \\
\hline ERROR & 22.000 & 51 & 0.431 & & \\
\hline 7 & 1.231 & 1 & 1.231 & 2.757 & 0.103 \\
\hline ERROR & 22.769 & 51 & 0.446 & & \\
\hline 8 & 3.250 & 1 & 3.250 & 8.392 & 0.006 \\
\hline ERROR & 19.750 & 51 & 0.387 & & \\
\hline 9 & 3.250 & 1 & 3.250 & 5.571 & 0.022 \\
\hline ERROR & 29.750 & 51 & 0.583 & & \\
\hline 10 & 0.942 & 1 & 0.942 & 1.998 & 0.164 \\
\hline ERROR & 24.058 & 51 & 0.472 & & \\
\hline 11 & 2.327 & 1 & 2.327 & 7.118 & 0.010 \\
\hline ERROR & 16.673 & 51 & 0.327 & & \\
\hline 12 & 4.923 & 1 & 4.923 & 11.912 & 0.001 \\
\hline ERROR & 21.077 & 51 & 0.413 & & \\
\hline 13 & 3.250 & 1 & 3.250 & 5.973 & 0.018 \\
\hline ERROR & 27.750 & 51 & 0.544 & & \\
\hline 14 & 0.692 & 1 & 0.692 & 1.395 & 0.243 \\
\hline ERROR & 25.308 & 51 & 0.496 & & \\
\hline 15 & 2.327 & 1 & 2.327 & 6.355 & 0.015 \\
\hline
\end{tabular}




$\begin{array}{rrrrrr}\text { ERROR } & 18.673 & 51 & 0.366 & & \\ 16 & 0.692 & 1 & 0.692 & 1.205 & 0.278 \\ \text { ERROR } & 29.308 & 51 & 0.575 & \end{array}$

MULTIVARIATE TEST STATISTICS

\begin{tabular}{|c|c|c|c|c|c|c|c|c|c|}
\hline WILKS' LAMBDA & $=$ & 0.530 & & & & & & & \\
\hline F-STATISTIC & $=$ & 1.995 & DF & $=$ & 16 & 36 & PROB & $=$ & 0.043 \\
\hline PILLAI TRACE & $=$ & 0.470 & & & & & & & \\
\hline E-STATISTIC & $=$ & 1.995 & $D E$ & - & 16 & 36 & PROB & $=$ & 0.043 \\
\hline G-LAWLEY TRACE & * & 0.887 & & & & & & & \\
\hline F-STATISTIC & $=$ & 1.995 & DE & - & 16 & 36 & PROB & $=$ & 0.043 \\
\hline
\end{tabular}

17 CASES DELETED DUE TO MISSING DATA.

NUMBER OE CASES PROCESSED: 48

DEPENDENT VARIABLE MEANS

\begin{tabular}{|c|c|c|c|c|}
\hline TIME (35) & $\operatorname{TIME}(36)$ & $\operatorname{TIME}(37)$ & TIME (38) & TIME (39) \\
\hline 3.250 & 2.854 & 2.979 & 3.000 & 3.208 \\
\hline $\operatorname{TIME}(40)$ & TIME (41) & TIME (42) & TIME (43) & TIME (44) \\
\hline 3.146 & 3.083 & 3.208 & 3.042 & 3.188 \\
\hline $\operatorname{TIME}(45)$ & $\operatorname{TIME}(46)$ & $\operatorname{TIME}(47)$ & $\operatorname{TIME}(48)$ & TIHE (49) \\
\hline
\end{tabular}




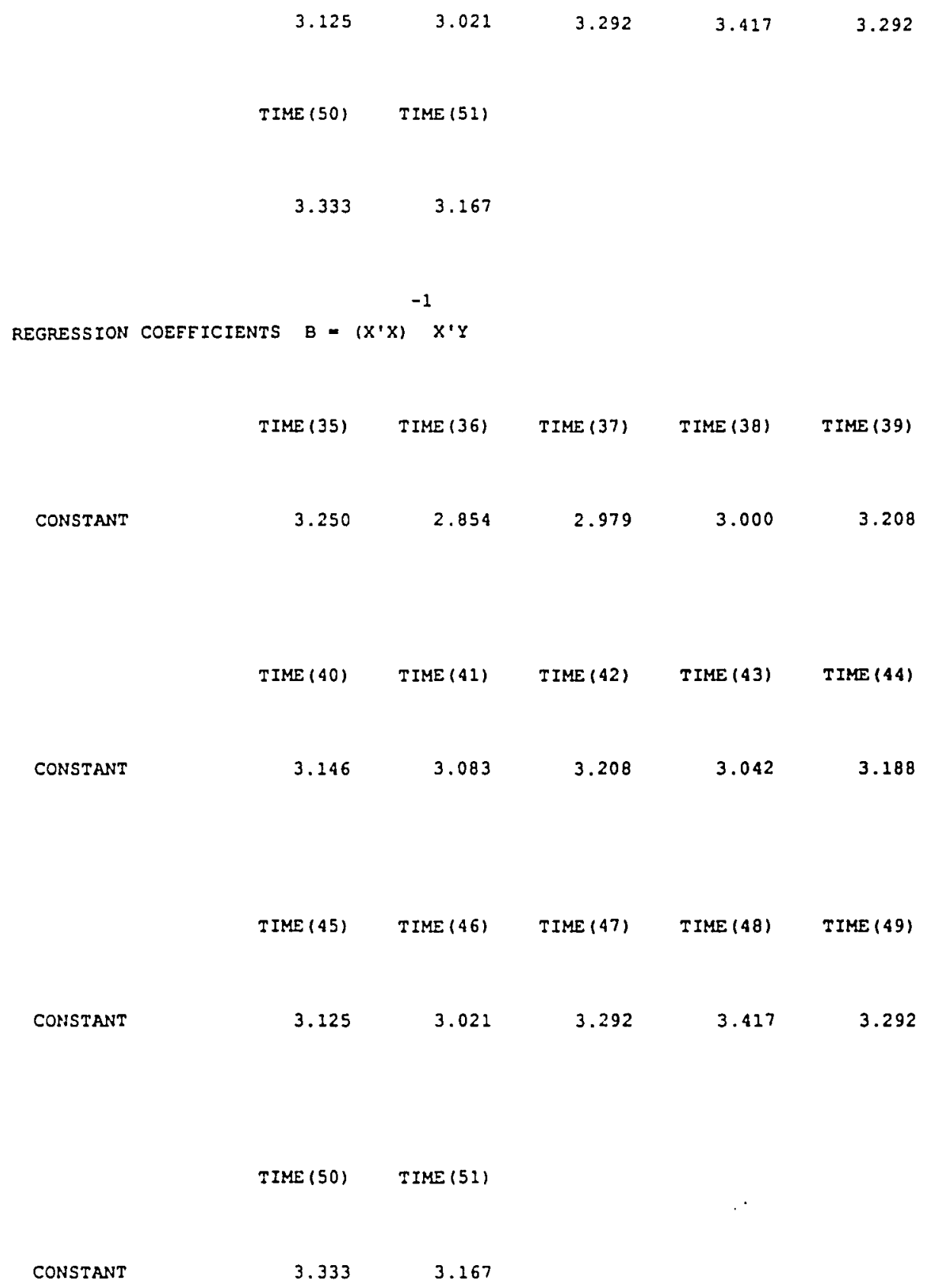


MULTIPLE CORRELATIONS

\begin{tabular}{|c|c|c|c|c|}
\hline $\operatorname{TIME}(35)$ & $\operatorname{TIME}(36)$ & $\operatorname{TIME}(37)$ & $\operatorname{TIME}(38)$ & $\operatorname{TIME}(39)$ \\
\hline 0.000 & 0.000 & 0.000 & 0.000 & 0.000 \\
\hline $\operatorname{TIME}(40)$ & TIME (41) & $\operatorname{TIME}(42)$ & $\operatorname{TIME}(43)$ & $\operatorname{TIME}(44)$ \\
\hline 0.000 & 0.000 & 0.000 & 0.000 & 0.000 \\
\hline $\operatorname{TIME}(45)$ & $\operatorname{TIME}(46)$ & $\operatorname{TIME}(47)$ & $\operatorname{TIME}(48)$ & $\operatorname{TIME}(49)$ \\
\hline 0.000 & 0.000 & 0.000 & 0.000 & 0.000 \\
\hline $\operatorname{TIME}(50)$ & $\operatorname{TIME}(51)$ & & & \\
\hline 0.000 & 0.000 & & & \\
\hline
\end{tabular}

HYPOTHESIS .

C MATRIX 


$\begin{array}{rrrrr}1.000 & -1.000 & 0.000 & 0.000 & 0.000 \\ 0.000 & 1.000 & -1.000 & 0.000 & 0.000 \\ 0.000 & 0.000 & 1.000 & -1.000 & 0.000 \\ 0.000 & 0.000 & 0.000 & 1.000 & -1.000 \\ 0.000 & 0.000 & 0.000 & 0.000 & 1.000 \\ 0.000 & 0.000 & 0.000 & 0.000 & 0.000 \\ 0.000 & 0.000 & 0.000 & 0.000 & 0.000 \\ 0.000 & 0.000 & 0.000 & 0.000 & 0.000 \\ 0.000 & 0.000 & 0.000 & 0.000 & 0.000 \\ 0.000 & 0.000 & 0.000 & 0.000 & 0.000 \\ 0.000 & 0.000 & 0.000 & 0.000 & 0.000 \\ 0.000 & 0.000 & 0.000 & 0.000 & 0.000 \\ 0.000 & 0.000 & 0.000 & 0.000 & 0.000 \\ 0.000 & 0.000 & 0.000 & 0.000 & 0.000 \\ 0.000 & 0.000 & 0.000 & 0.000 & 0.000 \\ 0.000 & 0.000 & 0.000 & 0.000 & 0.000\end{array}$




$\begin{array}{rrrrrr}1 & 0.000 & 0.000 & 0.000 & 0.000 & 0.000 \\ 2 & 0.000 & 0.000 & 0.000 & 0.000 & 0.000 \\ 3 & 0.000 & 0.000 & 0.000 & 0.000 & 0.000 \\ 4 & 0.000 & 0.000 & 0.000 & 0.000 & 0.000 \\ 5 & 0.000 & 0.000 & 0.000 & 0.000 & 0.000 \\ 6 & 0.000 & 0.000 & 0.000 & 0.000 & 0.000 \\ 7 & 0.000 & 0.000 & 0.000 & 0.000 & 0.000 \\ 8 & 0.000 & 0.000 & 0.000 & 0.000 & 0.000 \\ 9 & 0.000 & 0.000 & 0.000 & 0.000 & 0.000 \\ 10 & -1.000 & 0.000 & 0.000 & 0.000 & 0.000 \\ 11 & 1.000 & -1.000 & 0.000 & 0.000 & 0.000 \\ 12 & 0.000 & 1.000 & -1.000 & 0.000 & 0.000 \\ 13 & 0.000 & 0.000 & 1.000 & -1.000 & 0.000 \\ 14 & 0.000 & 0.000 & 0.000 & 1.000 & -1.000 \\ 15 & 0.000 & 0.000 & 0.000 & 0.000 & 1.000 \\ 16 & 0.000 & 0.000 & 0.000 & 0.000 & 0.000\end{array}$

$\begin{array}{rrr}1 & 0.000 & 0.000 \\ 2 & 0.000 & 0.000 \\ 3 & 0.000 & 0.000 \\ 4 & 0.000 & 0.000 \\ 5 & 0.000 & 0.000 \\ 6 & 0.000 & 0.000 \\ 7 & 0.000 & 0.000 \\ 8 & 0.000 & 0.000 \\ 9 & 0.000 & 0.000 \\ 10 & 0.000 & 0.000 \\ 11 & 0.000 & 0.000 \\ 12 & 0.000 & 0.000 \\ 13 & 0.000 & 0.000 \\ 14 & 0.000 & 0.000 \\ 15 & -1.000 & 0.000 \\ 16 & 1.000 & -1.000\end{array}$

UNIVARIATE E TESTS 


\begin{tabular}{|c|c|c|c|c|c|}
\hline AP.IABLE & SS & DF & MS & $E$ & $P$ \\
\hline 1 & 7.521 & 1 & 7.521 & 13.873 & 0.001 \\
\hline ERROR & 25.479 & 47 & 0.542 & & \\
\hline 2 & 0.750 & 1 & 0.750 & 1.060 & 0.308 \\
\hline ERROR & 33.250 & 47 & 0.707 & & \\
\hline 3 & 0.021 & 1 & 0.021 & 0.075 & 0.785 \\
\hline ERROR & 12.979 & 47 & 0.276 & & \\
\hline 4 & 2.083 & 1 & 2.083 & 3.068 & 0.086 \\
\hline ERROR & 31.917 & 47 & 0.679 & & \\
\hline 5 & 0.188 & 1 & 0.188 & 0.329 & 0.569 \\
\hline ERROR & 26.813 & 47 & 0.570 & & \\
\hline 6 & 0.188 & 1 & 0.188 & 0.269 & 0.607 \\
\hline ERROR & 32.813 & 47 & 0.698 & & \\
\hline 7 & 0.750 & 1 & 0.750 & 1.294 & 0.261 \\
\hline ERROR & 27.250 & 47 & 0.580 & & \\
\hline 8 & 1.333 & 1 & 1.333 & 5.875 & 0.019 \\
\hline ERROP. & 10.667 & 47 & 0.227 & & \\
\hline 9 & 1.021 & 1 & 1.021 & 2.401 & 0.128 \\
\hline ERROR & 19.979 & 47 & 0.425 & & \\
\hline 10 & 0.187 & 1 & 0.187 & 0.386 & 0.537 \\
\hline ERROR & 22.813 & 47 & 0.485 & & \\
\hline 11 & 0.521 & 2 & 0.521 & 1.089 & 0.302 \\
\hline ERROR & 22.479 & 47 & 0.478 & & \\
\hline 12 & 3.521 & 1 & 3.521 & 5.613 & 0.022 \\
\hline ERROR & 29.479 & 47 & 0.627 & & \\
\hline 13 & 0.750 & 1 & 0.750 & 1.831 & 0.182 \\
\hline ERROR & 19.250 & 47 & 0.410 & & \\
\hline 14 & 0.750 & 1 & 0.750 & 2.043 & 0.159 \\
\hline ERROR & 17.250 & 47 & 0.367 & & \\
\hline 15 & 0.083 & 1 & 0.083 & 0.197 & 0.659 \\
\hline ERROR & 19.917 & 47 & 0.424 & & \\
\hline 16 & 1.333 & 1 & 1.333 & 2.765 & 0.103 \\
\hline ERROR & 22.667 & 47 & 0.482 & & \\
\hline
\end{tabular}

MULTIVARIATE TEST STATISTICS

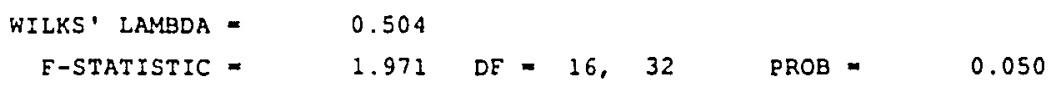




\begin{tabular}{|c|c|c|c|c|c|c|}
\hline PILLAI TRACE & 0.496 & & & & & \\
\hline F-STATISTIC & 1.971 & $D E=$ & 16, & 32 & PROB $=$ & 0.050 \\
\hline HOTELLING-LAWLEY TRACE & 0.985 & & & & & \\
\hline F-STATISTIC & 1.971 & $D F=$ & 16 , & 32 & PROB = & 0.050 \\
\hline
\end{tabular}

9 CASES DELETED DUE TO MISSING DATA.

NUMBER OF CASES PROCESSED: 56

DEPENDENT VARIABLE MEANS

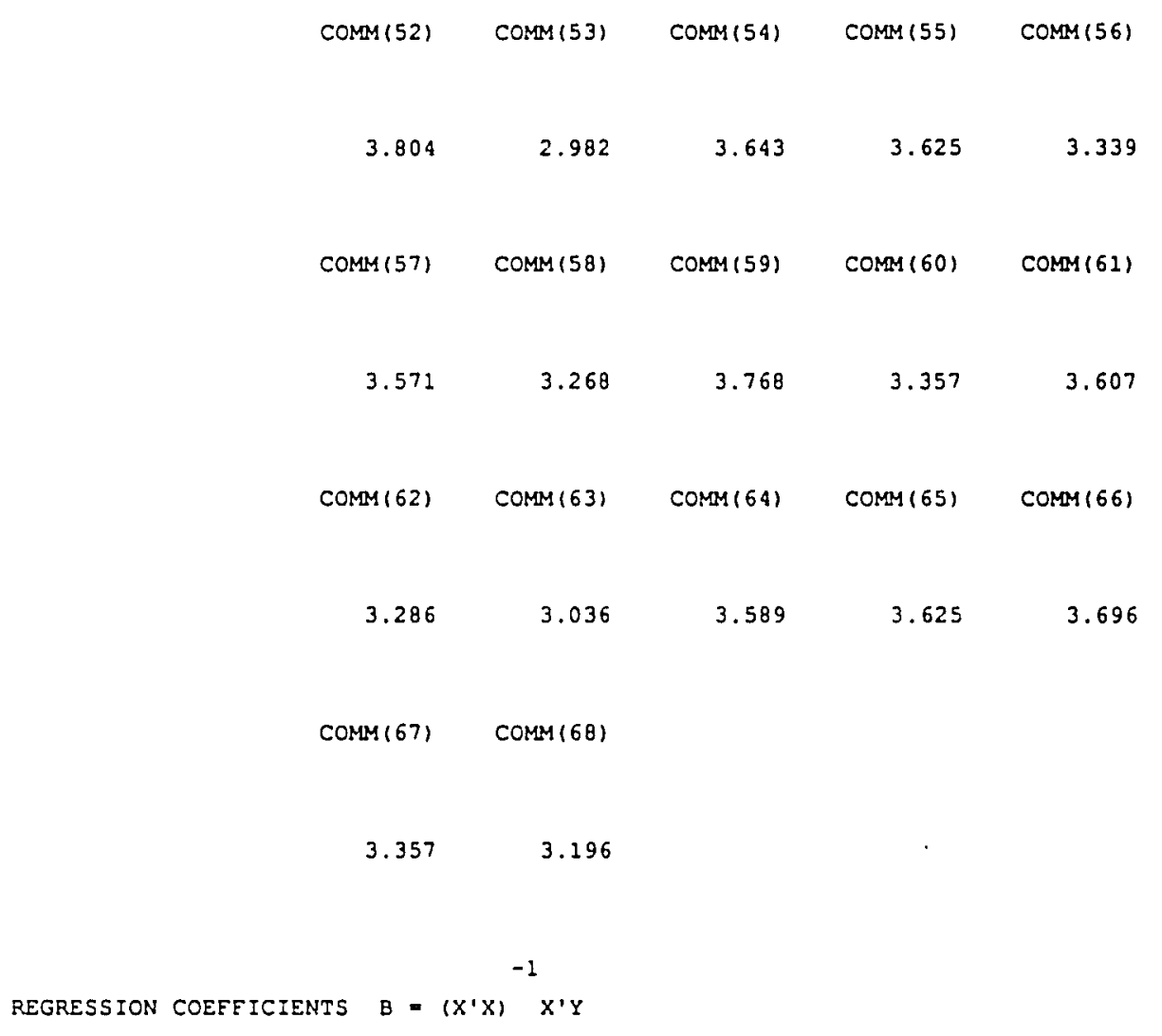




\begin{tabular}{|c|c|c|c|c|c|}
\hline & $\operatorname{COMM}(52)$ & $\operatorname{COMM}(53)$ & $\operatorname{COMM}(54)$ & $\operatorname{COMM}(55)$ & $\operatorname{COMM}(56)$ \\
\hline \multirow[t]{2}{*}{ CONSTANT } & 3.804 & 2.982 & 3.643 & 3.625 & 3.339 \\
\hline & $\operatorname{COMM}(57)$ & $\operatorname{ComM}(58)$ & $\operatorname{COM}(59)$ & $\operatorname{COMM}(60)$ & $\operatorname{COM}(61)$ \\
\hline \multirow[t]{2}{*}{ CONSTANT } & 3.571 & 3.268 & 3.768 & 3.357 & 3.607 \\
\hline & $\operatorname{COMM}(62)$ & $\operatorname{COMM}(63)$ & $\operatorname{COM}(64)$ & $\operatorname{COM}(65)$ & $\operatorname{COM}(66)$ \\
\hline \multirow[t]{2}{*}{ CONSTANT } & 3.286 & 3.036 & 3.589 & 3.625 & 3.696 \\
\hline & $\operatorname{COMM}(67)$ & $\operatorname{COMM}(68)$ & & & \\
\hline CONSTANT & 3.357 & 3.196 & & & \\
\hline
\end{tabular}

MULTIPLE CORRELATIONS

$\begin{array}{rrrrr}\operatorname{COM}(52) & \operatorname{COMM}(53) & \operatorname{COMM}(54) & \text { COMM(55) } & \text { COMM(56) } \\ & & & & \\ 0.000 & 0.000 & 0.000 & 0.000 & 0.000\end{array}$




$\begin{array}{lrrrr}\operatorname{COM}(57) & \operatorname{COM}(58) & \operatorname{COM}(59) & \operatorname{COMM}(60) & \operatorname{COMM}(61) \\ 0.000 & 0.000 & 0.000 & 0.000 & 0.000 \\ \operatorname{COMM}(62) & \operatorname{COMM}(63) & \operatorname{COMM}(64) & \operatorname{COMM}(65) & \operatorname{COMM}(66) \\ 0.000 & 0.000 & 0.000 & 0.000 & 0.000 \\ \operatorname{COMM}(67) & \operatorname{COMM}(68) & & & \\ 0.000 & 0.000 & & & \end{array}$

HYPOTHESIS .

C MATRIX

1

2

3

4

5

$\begin{array}{rrrrrr}1 & 1.000 & -1.000 & 0.000 & 0.000 & 0.000 \\ 2 & 0.000 & 1.000 & -1.000 & 0.000 & 0.000 \\ 3 & 0.000 & 0.000 & 1.000 & -1.000 & 0.000 \\ 4 & 0.000 & 0.000 & 0.000 & 1.000 & -1.000 \\ 5 & 0.000 & 0.000 & 0.000 & 0.000 & 1.000 \\ 6 & 0.000 & 0.000 & 0.000 & 0.000 & 0.000 \\ 7 & 0.000 & 0.000 & 0.000 & 0.000 & 0.000 \\ 8 & 0.000 & 0.000 & 0.000 & 0.000 & 0.000 \\ 9 & 0.000 & 0.000 & 0.000 & 0.000 & 0.000\end{array}$


0.000

0.000

0.000

0.000

0.000

0.000

0.000

0.000

0.000

0.000

0.000

0.000

0.000

0.000

0.000

0.000

0.000

0.000

0.000

0.000

0.000

0.000

0.000

0.000

0.000

0.000

0.000

0.000

0.000

0.000

0.000

0.000

0.000

0.000

0.000

6

7

$B$

9

10

$$
\begin{array}{r}
0.000 \\
0.000 \\
0.000 \\
0.000 \\
-1.000 \\
1.000 \\
0.000 \\
0.000 \\
0.000 \\
0.000 \\
0.000 \\
0.000 \\
0.000 \\
0.000 \\
0.000 \\
0.000
\end{array}
$$

11

0.000

0.000

0.000

0.000

0.000

0.000

0.000

0.000

0.000

$-1.000$
0.000

0.000

0.000

0.005

0.000

$-1.000$

1.000

0.000

0.000

0.000

0.000

0.000

0.000

0.000

0.000

0.000

12

0.000

0.000

0.000

0.000

0.000

0.000

0.000

0.000

0.000

0.000
0.000

0.000

0.000

0.000

0.000

0.000

$-1.000$

1.000

0.000

0.000

0.000

0.000

0.000

0.000

0.000

0.000

13

0.000

0.000

0.000

0.000

0.000

0.000

0.000

0.000

0.000

0.000
0.000

0.000

0.000

0.000

0.000

0.000

0.000

$-1.000$

1.000

0.000

0.000

0.000

0.000

0.000

0.000

0.000

14

0.000

0.000

0.000

0.000

0.000

0.000

0.000

0.000

0.000

0.000
0.000

0.000

0.000

0.000

0.000

0.000

0.000

0.000

$-1.000$

1.000

0.000

0.000

0.000

0.000

0.000

0.000

15

0.000

0.000

0.000

0.000

0.000

0.000

0.000

0.000

0.000

0.000 


$\begin{array}{rrrrrr}11 & 1.000 & -1.000 & 0.000 & 0.000 & 0.000 \\ 12 & 0.000 & 1.000 & -1.000 & 0.000 & 0.000 \\ 13 & 0.000 & 0.000 & 1.000 & -1.000 & 0.000 \\ 14 & 0.000 & 0.000 & 0.000 & 1.000 & -1.000 \\ 15 & 0.000 & 0.000 & 0.000 & 0.000 & 1.000 \\ 16 & 0.000 & 0.000 & 0.000 & 0.000 & 0.000\end{array}$

16

$\begin{array}{rrr}1 & 0.000 & 0.000 \\ 2 & 0.000 & 0.000 \\ 3 & 0.000 & 0.000 \\ 4 & 0.000 & 0.000 \\ 5 & 0.000 & 0.000 \\ 6 & 0.000 & 0.000 \\ 7 & 0.000 & 0.000 \\ 8 & 0.000 & 0.000 \\ 9 & 0.000 & 0.000 \\ 10 & 0.000 & 0.000 \\ 11 & 0.000 & 0.000 \\ 12 & 0.000 & 0.000 \\ 13 & 0.000 & 0.000 \\ 14 & 0.000 & 0.000 \\ 15 & -1.000 & 0.000 \\ 16 & 1.000 & -1.000\end{array}$

UNIVARIATE $F$ TESTS

\begin{tabular}{rrrrrl} 
VARIABLE & \multicolumn{1}{l}{ SS } & DE & \multicolumn{1}{l}{ MS } & F & P \\
& & & & & \\
1 & 37.786 & 1 & 37.786 & 38.333 & 0.000 \\
ERROR & 54.214 & 55 & 0.986 & & \\
2 & 24.446 & 1 & 24.446 & 17.564 & 0.000 \\
ERROR & 76.554 & 55 & 1.392 & & 0.799 \\
3 & 0.018 & 1 & 0.018 & 0.066 & \\
ERROR & 14.982 & 55 & 0.272 & & 0.073 \\
4 & 4.571 & 1 & 4.571 & 3.333 &
\end{tabular}




\begin{tabular}{|c|c|c|c|c|c|}
\hline 5 & 3.018 & 1 & 3.018 & 2.678 & 0.107 \\
\hline ERROR & 61.982 & 55 & 1.127 & & \\
\hline 6 & 5.161 & 1 & 5.161 & 5.272 & 0.026 \\
\hline ERROR & 53.839 & 55 & 0.979 & & \\
\hline 7 & 14.000 & 1 & 14.000 & 27.500 & 0.000 \\
\hline ERROR & 28.000 & 55 & 0.509 & & \\
\hline 8 & 9.446 & 1 & 9.446 & 16.466 & 0.000 \\
\hline ERROR & 31.554 & 55 & 0.574 & & \\
\hline 9 & 3.500 & 1 & 3.500 & 10.405 & 0.002 \\
\hline ERROR & 18.500 & 55 & 0.336 & & \\
\hline 10 & 5.786 & 1 & 5.786 & 8.787 & 0.004 \\
\hline ERROR & 36.214 & 55 & 0.658 & & \\
\hline 11 & 3.500 & 1 & 3.500 & 6.754 & 0.012 \\
\hline ERROR & 28.500 & 55 & 0.518 & & \\
\hline 12 & 17.161 & 1 & 17.161 & 33.903 & 0.000 \\
\hline ERROR & 27.839 & 55 & 0.506 & & \\
\hline 13 & 0.071 & 1 & 0.071 & 0.131 & 0.719 \\
\hline ERROR & 29.929 & 55 & 0.544 & & \\
\hline 14 & 0.286 & 1 & 0.286 & 0.466 & 0.498 \\
\hline ERROR & 33.714 & 55 & 0.613 & & \\
\hline 15 & 6.446 & 1 & 6.446 & 13.352 & 0.001 \\
\hline ERROR & 26.554 & 55 & 0.483 & & \\
\hline 16 & 1.446 & 1 & 1.446 & 1.543 & 0.219 \\
\hline ERROR & $5 i .554$ & 55 & 0.937 & & \\
\hline
\end{tabular}

MULTIVARIATE TEST STATISTICS

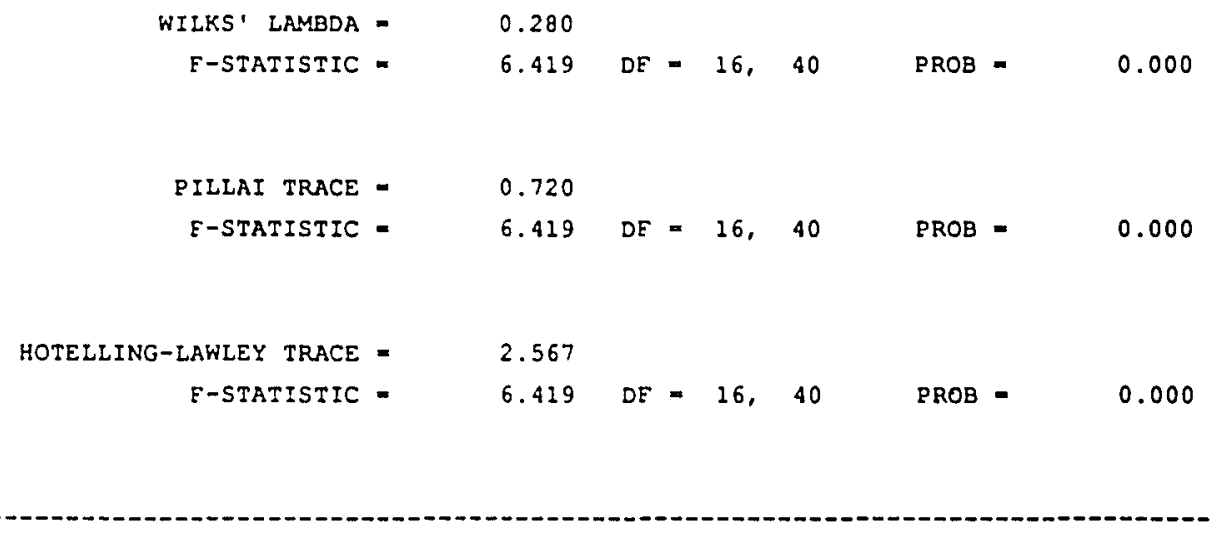


APPENDIX J

RATIO DATA GRAPHS 

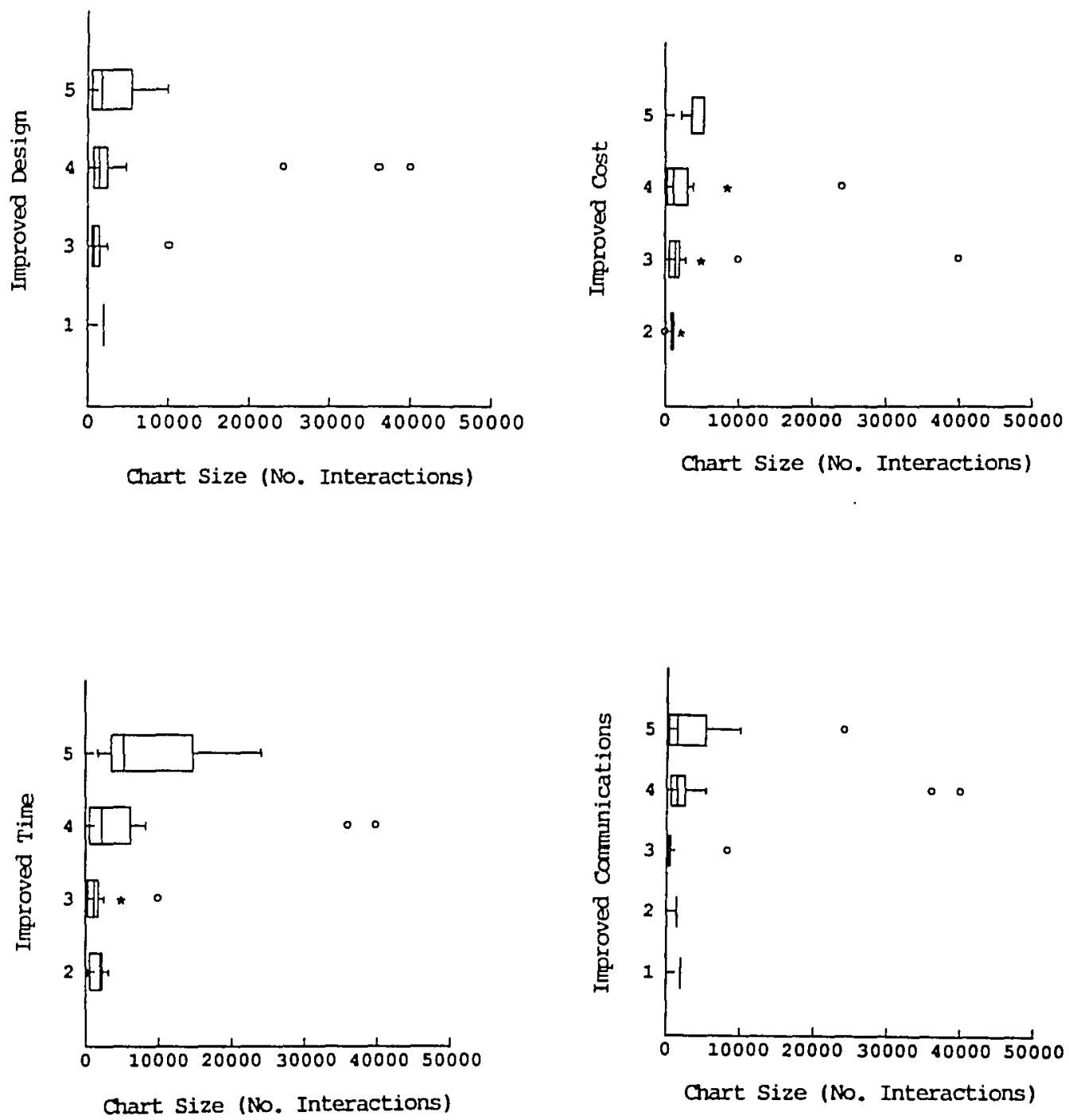

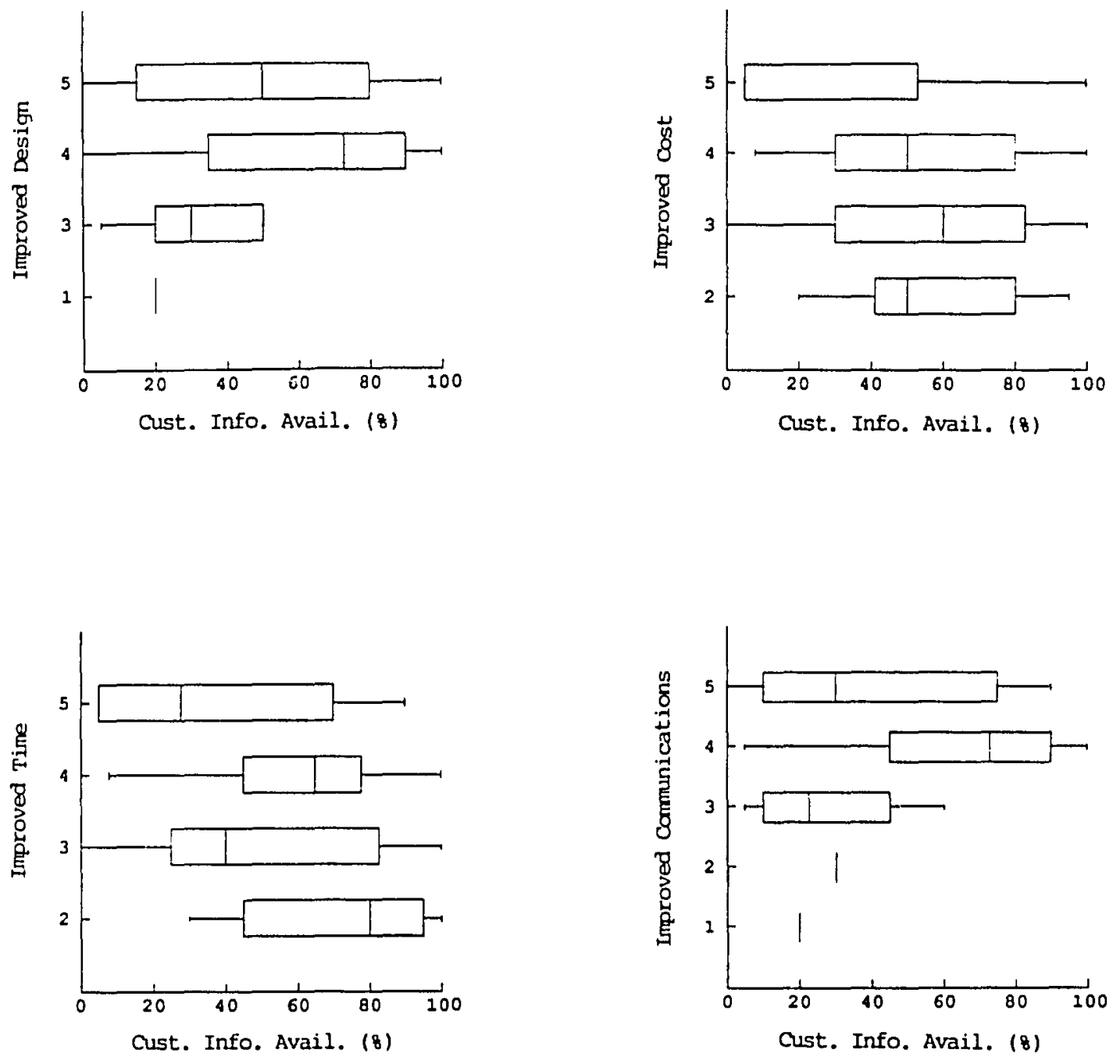

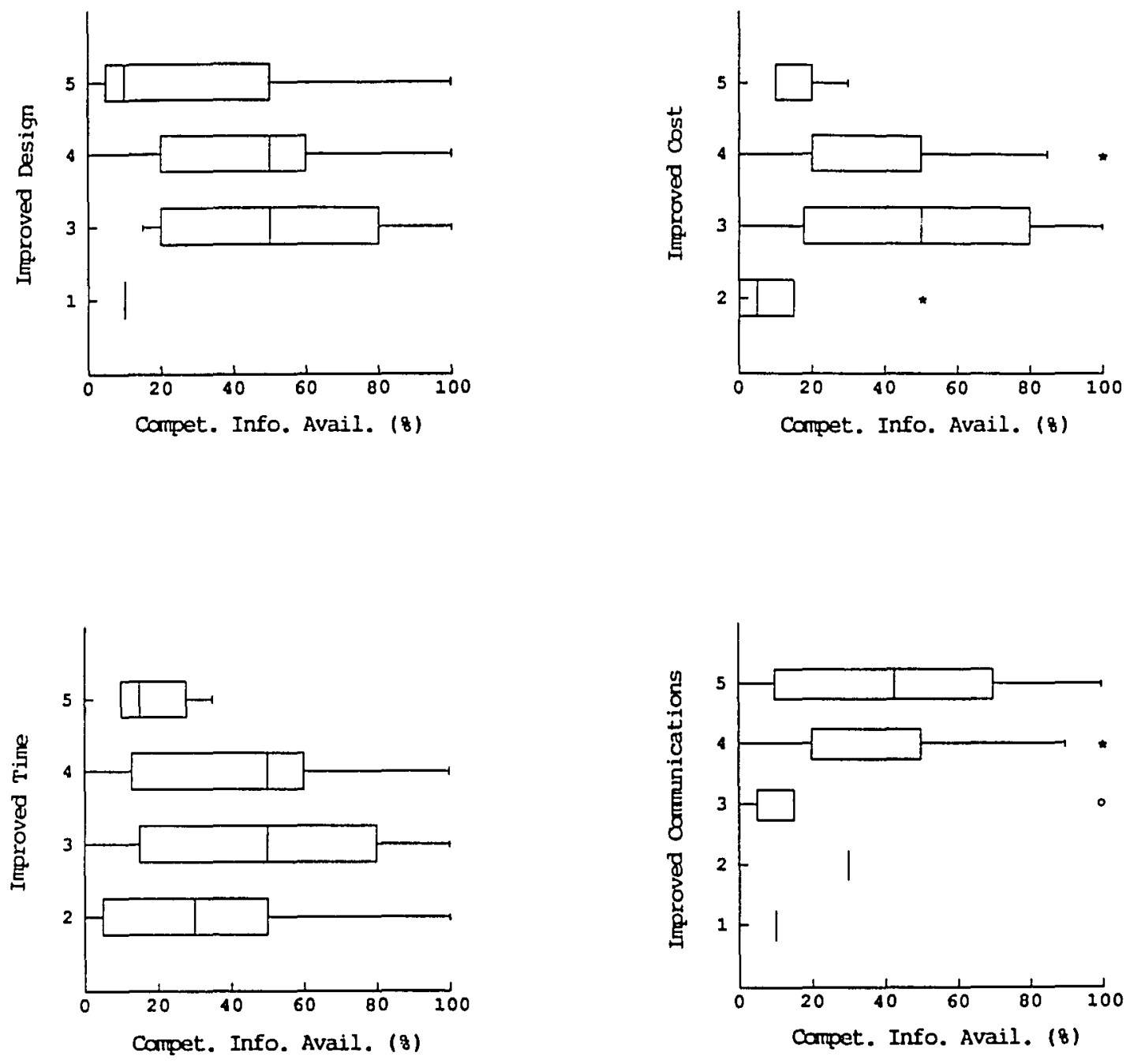

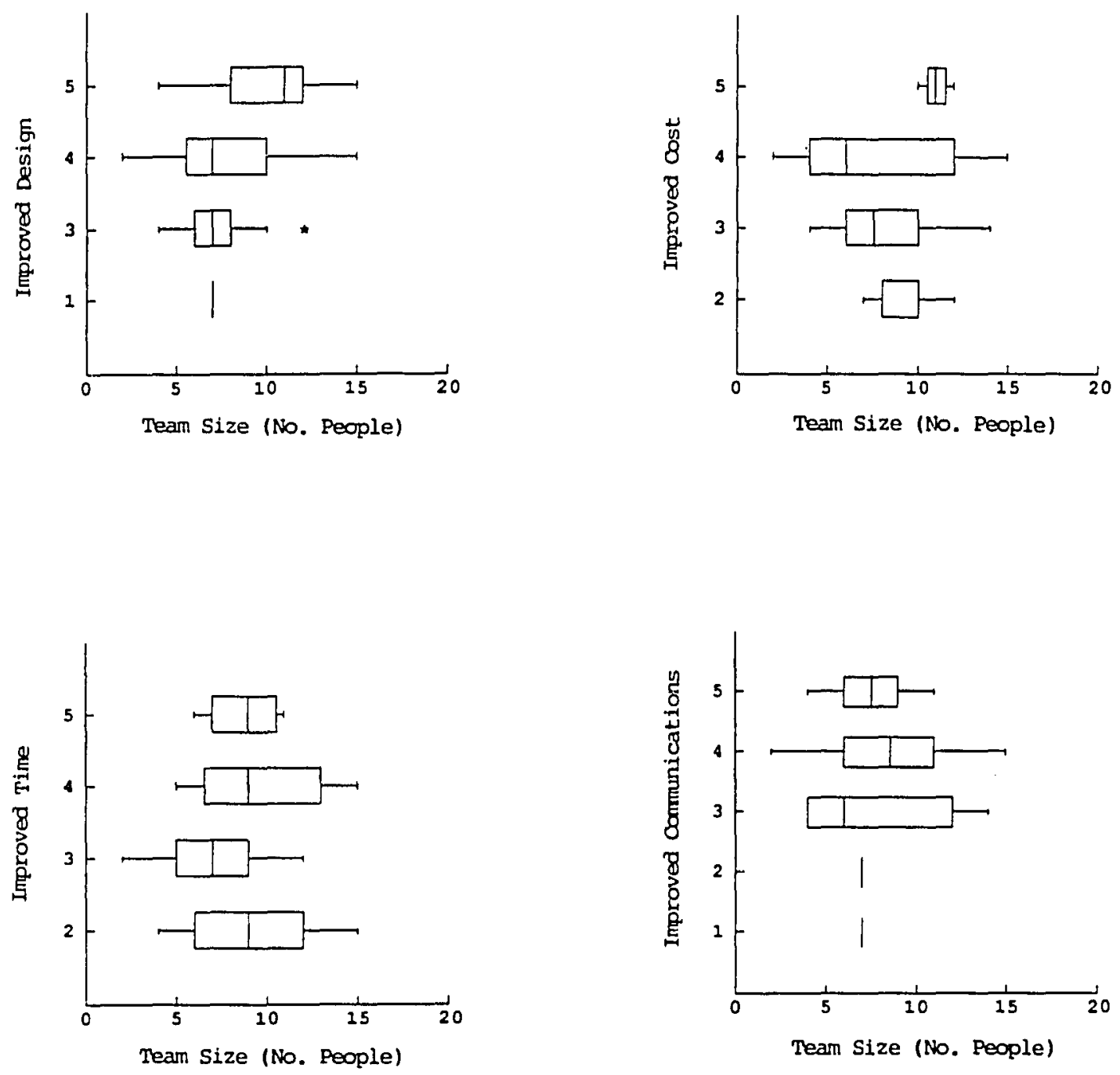

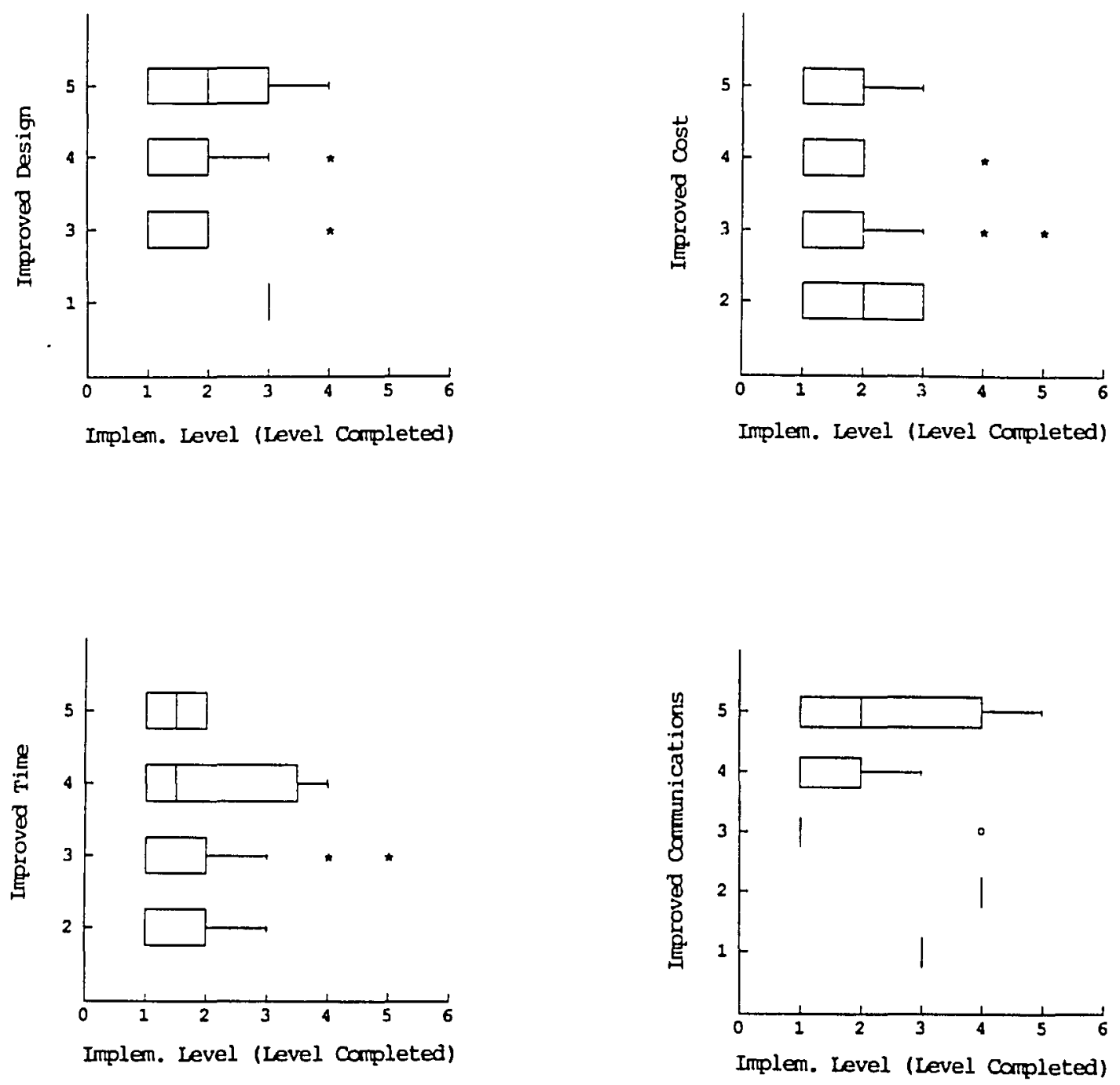

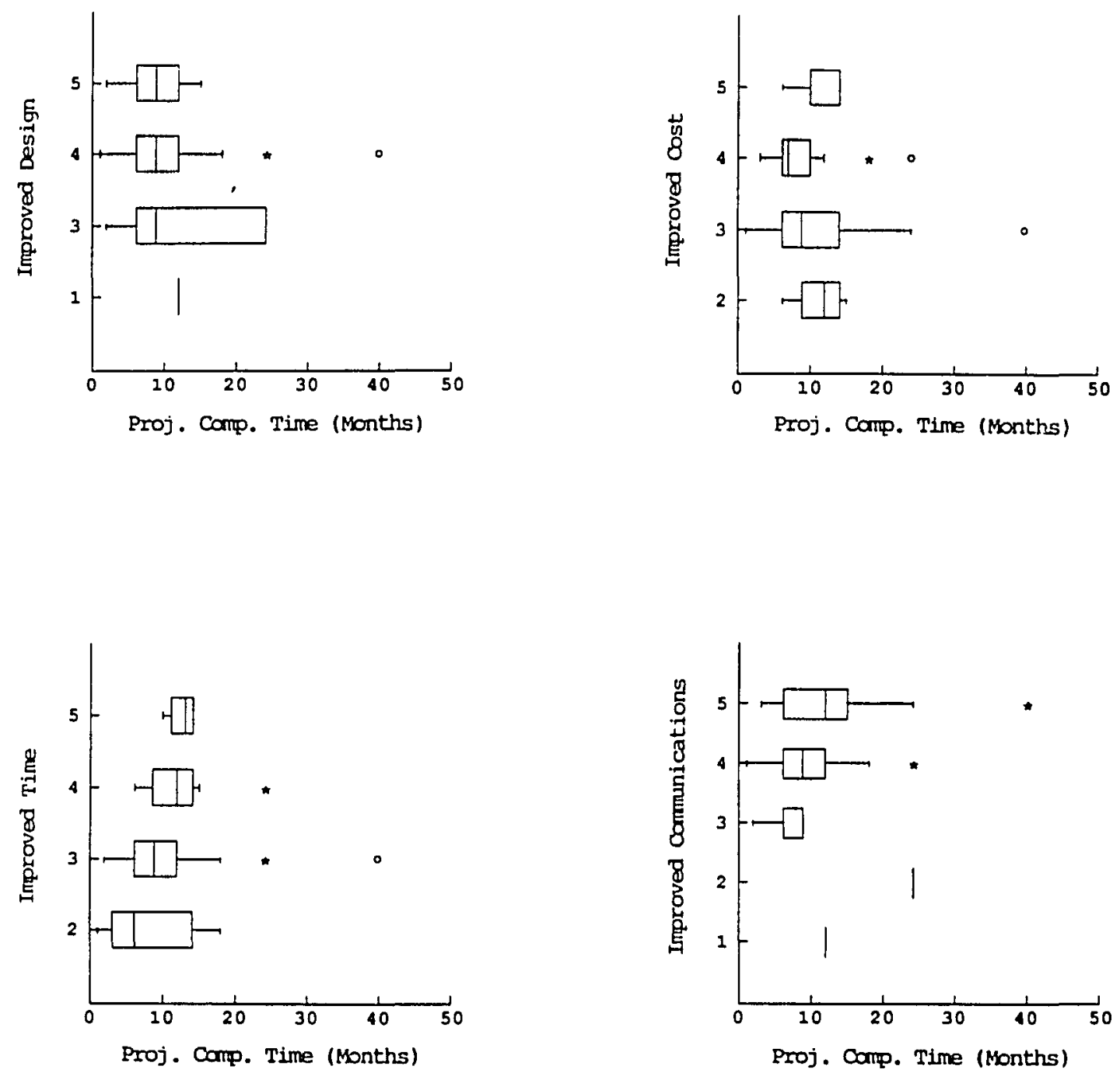
APPENDIX K

DR. W. EDWARDS DEMING 'S REVIEW COMMENTS 
To The Office Of Graduate Studies:

I have reviewed the dissertation of Geoffrey Paul Gilmore. My comments have been communicated to Geoffrey Paul Gilmore who has understood and satisfactorily responded to them. With those comments and responses in mind, I approve the dissertation of Geoffrey Paul Gilmore.

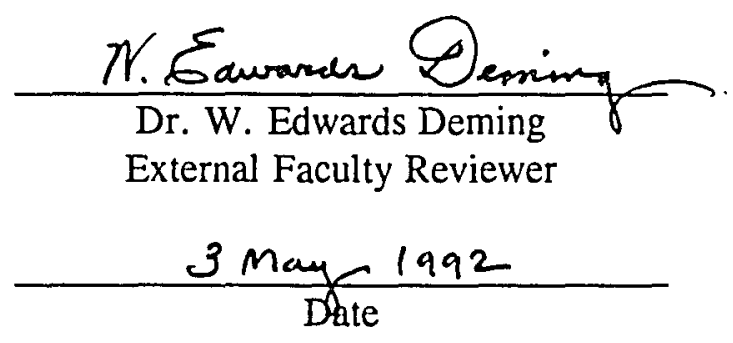

